ANA WANSUL LIU

DIRETRIZES PARA PROJETOS DE EDIFÍCIOS DE ESCRITÓRIOS

Dissertação apresentada à Escola Politécnica da Universidade de São Paulo para obtenção do título de Mestre em Engenharia 


\section{DIRETRIZES PARA PROJETOS DE EDIFÍCIOS DE ESCRITÓRIOS}

Dissertação apresentada à Escola Politécnica da Universidade de São Paulo para obtenção do título de Mestre em Engenharia

Área de Concentração:

Engenharia Civil e Urbana

Orientador: Prof. Livre-Docente Silvio Burrattino Melhado 


\section{DEDICATÓRIA}

Dedico este trabalho aos meus pais, Cheng Shang e Lee San (in memorian), por me ensinarem, entre todas as outras coisas, a importância do estudo, e à minha família, Nelson, Ian e Beatriz, pelo amor recíproco e incondicional. 


\section{AGRADECIMENTOS}

A Silvio B. Melhado, que criou a primeira motivação para minha entrada no mundo acadêmico, e que fez uma orientação objetiva e gratificante do trabalho.

Aos professores Francisco Segnini Junior e Brenda Chaves Coelho Leite, que fizeram a leitura cuidadosa da qualificação e trouxeram críticas valiosas e construtivas, além de recomendações bibliográficas.

A Luiz Henrique Ceotto, que sugeriu o tema do trabalho e providenciou o acesso a todos os dados necessários para o estudo de caso.

À arquiteta Beatriz Abdalla, que me acompanhou nas reuniões de coordenação de projetos dos empreendimentos do estudo de caso.

À professora Maria Cristina V. Borba, pela revisão do inglês do Abstract e por desvendar parte dos mistérios da língua inglesa para fins acadêmicos.

Aos professores e profissionais Mario Franco e Ricardo L. S. França, pelos comentários e correções do texto de estrutura, e pela indicação de referências bibliográficas.

A José Luiz de Martini, pelos comentários sobre o texto de sistemas prediais elétricos e pela indicação de artigos pertinentes.

À professora Lúcia Helena de Oliveira, por ter me possibilitado uma abertura de olhar em relação aos sistemas prediais hidráulicos.

A Eduardo Grecco, pela agradável aula informal sobre ar condicionado.

A Jayme Spinola Castro Neto, pela disponibilidade para trocar idéias sobre a importância dos sistemas de automação predial no contexto da arquitetura. 
A Luciana de Oliveira, por ter gentilmente cedido trechos de sua tese de doutorado.

A Moacyr Motta Filho, pelas referências bibliográficas sobre sistemas de transporte vertical.

A Marcos Kowalewski e Alexandre Ventura Martins, pelas valiosas informações sobre gerenciamento de facilidades sob a ótica do mercado.

A José Fiasco, pelas informações sobre gerenciamento de propriedades do estudo de caso e pelo empréstimo de seus livros pessoais.

Ao professor Moacyr Eduardo Alves da Graça, pelas explanações conceituais sobre gerenciamento de propriedades e de facilidades.

A Roberto de Souza, pelo acesso ao evento Encontro Internacional de Sustentabilidade na Construção de 2008.

Aos meus queridos amigos "orbitais": Rosely, Edison, Medina e Renato, que forneceram diversos desenhos para composição deste trabalho, esbanjaram bom humor e me deram muita motivação para seguir em frente.

A querida Lilian A. P. Faversani, pela cuidadosa revisão do texto e pelas incontáveis vezes em que ela esteve disponível para estar com meus pequenos durante minhas reuniões de pesquisa.

Ao CNPq - Conselho Nacional de Pesquisa - pela bolsa concedida durante a realização do trabalho. 


\section{RESUMO}

A complexidade no desenvolvimento de projetos para edifícios de escritórios está relacionada a dificuldades na conciliação de interesses de empreendedores, projetistas, construtores e usuários finais, e a diversidade e especialização cada vez maiores das disciplinas envolvidas. A clareza quanto aos pontos que devem ser definidos, e quem deve defini-los, ainda na fase de concepção deste tipo de projeto, é fundamental para que o empreendimento apresente viabilidades técnica, construtiva e de negócio, e a gestão do processo do projeto deve ter domínio total destas questões nesta fase. A proposta deste trabalho é apresentar as informações críticas das diversas disciplinas, que devem ser definidas ainda na concepção da arquitetura, e sua correta seqüência de inserção no processo. Para tal, a metodologia adotada baseia-se em revisão bibliográfica e na realização de um estudo de caso, cujas condições de contorno são consideradas ímpares: a empresa contratante de projetos é uma incorporadora que tem o domínio das informações sobre as necessidades mercadológicas do produto, tem um corpo técnico que apresenta condições de avaliar e escolher soluções técnicas construtivas, e também é uma empresa de administração predial, ou seja, opera o funcionamento do edifício construído, resultando em decisões de projeto que realmente focam o custo do empreendimento em seu ciclo da vida, o que não ocorre freqüentemente no mercado brasileiro. Propõe-se o desenvolvimento de um fluxo de informações de projetos que indique a necessidade e a etapa de cada informação na fase de concepção do projeto, o que ajuda a esclarecer o correto papel de cada agente no processo e constitui uma ferramenta extremamente útil para a gestão de projetos.

Palavras-chave: Edifício de escritório. Gestão do projeto. Processo do projeto. Fluxo de informações 


\begin{abstract}
The complexity in office buildings design development is related to difficulties in incorporating the interests of all the players involved (owners, designers, contractors and end-users) and to the increasing diversity of specialist designers. The clarity about key points definitions and who should make them, during the design conceptual phase, is imperative for technical, constructive and commercial feasibilities of the project itself, and design management must have complete control of these aspects. The aim is to investigate what critical information from several design subjects should be defined during this conceptual phase and its correct insertion sequence in the design process. In order to achieve this investigation, the research is based on the case study method, the studied object of which has distinctive conditions: the design team contractor is a real estate company that fully understands office building market needs, holds an experienced technical team to evaluate and select constructive solutions and, also, is a facility manager. Due to this, their design decisions actually focus on the project entire life cycle, which is not common in the Brazilian market. In conclusion, the development of an information flow is proposed, during the design conceptual phase, which indicates when each piece of information should be located in the design process, which is helpful to elucidate the correct function of each related player and to establish a useful tool for design management.
\end{abstract}

Keywords: Office buildings. Design management. Design process. Data flow. 


\section{ÍNDICE DE FIGURAS}

Figura 1 - Vista interior do edifício Larkin (EUA), construído em 1904 e demolido em 1949 24

Figura 2 - Representação parcial de um escritório panorâmico .25

Figura 3 - Sistemas modulares para individualização das estações de trabalho......25

Figura 4 - Alguns edifícios de escritório considerados como ícones, em diferentes regiões

Figura 5 - Potencial de influência no custo final de um empreendimento e suas fases

Figura 6 - Etapas da pesquisa.

Figura 7 - Ilustração, em planta tipo, dos diferentes critérios de consideração de áreas para cálculo por construtoras e para fins de aprovação legal ..... .42

Figura 8 - Ilustração, em planta tipo, do levantamento de área para locação pelo critério ANSI/ BOMA

Figura 9 - Quatro profundidades típicas de pavimento

Figura 10 - Planta de pavimento tipo indicando malha modular construtiva e profundidade do andar 48

Figura 11 - Corte esquemático de uma periferia de andar tipo.

Figura 12 - Tipologias de vedações verticais, sob o ponto de vista construtivo, e alguns exemplos (em cinza). .55

Figura 13 - Exemplos de edificações com fachadas leves, sendo: a) fachada-cortina

e b) fachada semi-cortina .57

Figura 14 - Exemplos de edifício de escritórios com fachada em placas pré-

fabricadas de concreto com granito incorporado 57

Figura 15 - Corte esquemático de uma fachada dupla ventilada. 58

Figura 16 - Exemplos de fachadas de edifícios de escritórios. .59

Figura 17 - Proporções consideradas ótimas de edificações de acordo com o clima

Figura 18 - Relação esquemática entre alternativas de soluções nos diferentes modos (passivo, ativo e produtivo) e impacto nos custos de implantação 64

Figura 19 - Ilustração da atuação de forças de pressão de vento (positivas e negativas) em modelo de teste 
Figura 20 - Ilustração de pavimento tipo e respectiva laje estrutural do edifício de

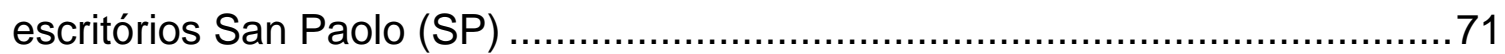

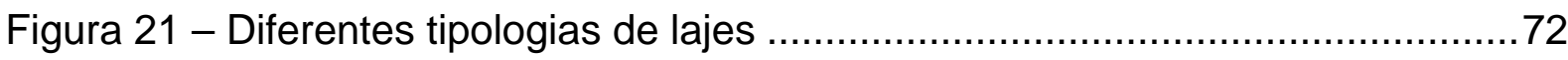

Figura 22 - Ilustração da estrutura de um pavimento tipo em laje plana, com previsão para interligação entre andares na área de escritórios........................76

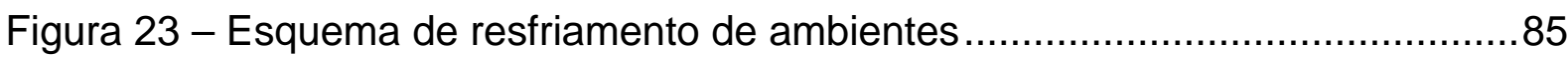

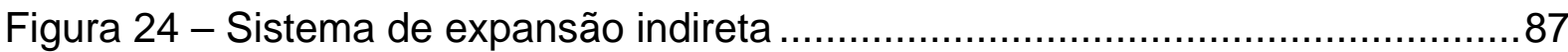

Figura 25 - Esquema hidráulico do sistema de expansão indireta ..........................88

Figura 26 - Desenho esquemático de distribuição do ar condicionado pelo forro ....90

Figura 27 - Desenho esquemático de distribuição do ar condicionado pelo piso .....91

Figura 28 - llustração esquemática das estratégias de desempenho passivo do

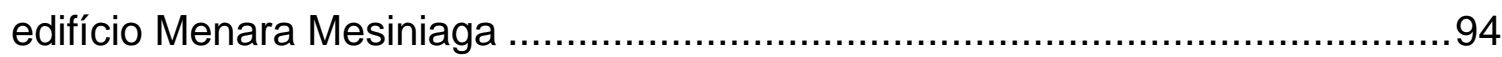

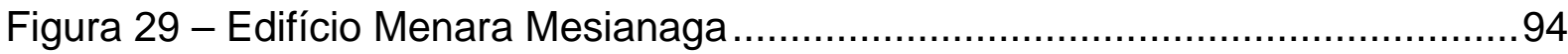

Figura 30 - Desenhos indicando esquemas de reservação de água fria.................100

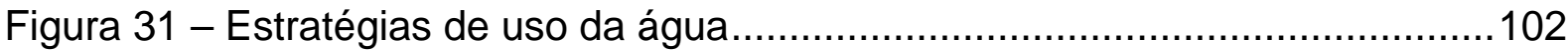

Figura 32 - Desenho esquemático de reservação de água fria e de aproveitamento

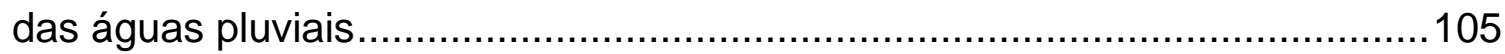

Figura 33 - Projeto do edifício Water Town, Chicago (EUA)...............................106

Figura 34 - Detalhe do projeto do edifício Water Town, Chicago (EUA)................ 106

Figura 35 - Exemplo de desconector do mictório seco ......................................108

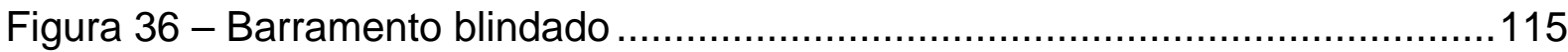

Figura 37 - Usina modular de geração de energia própria ....................................118

Figura 38 - Árvore conceitual da segurança contra incêndio e exemplos de disciplinas de projeto relacionadas 121

Figura 39 - Esquema básico de elevadores: (a) elétrico e seus componentes (válido para máquinas com e sem engrenagens) e (b) hidráulico ............................127

Figura 40 - Esquema simplificado de elevador sem casa de máquinas .................128

Figura 41 - Largura de portas de elevadores...................................................130

Figura 42 - Proporção da cabine do elevador..................................................131

Figura 43 - Velocidade de elevadores recomendada para edifícios não residenciais

Figura 44 - Intervalos de tráfego admissíveis para edifícios de escritórios ............132

Figura 45 - Sugestão de arranjos de elevadores em hall .....................................134 
Figura 46 - Controle do sistema de antecipação de chamadas.

Figura 47 - Exemplos de disposições de escadas rolantes

Figura 48 - Formulação do escopo do empreendimento em edifícios de escritório143

Figura 49 - Diversos arranjos de interação do coordenador de projetos com outros agentes

Figura 50 - Envolvimento dos agentes ao longo do processo de um empreendimento

Figura 51 - Perfil de despesas de ocupação de escritórios em 25 anos - sem considerar custos de salários

Figura 52 - Diagrama de controle do processo do projeto.

Figura 53 - Modelo genérico para organização do processo do projeto de forma integrada e simultânea

Figura 54 - Representação gráfica dos domínios de conhecimento abordados pela

gestão do processo do projeto integrado de edificações

Figura 55 - Desdobramentos do Gerenciamento de Patrimônio Imobiliário 153

Figura 56 - Uso estanque das ferramentas digitais de projeto 163

Figura 57 - Uso integrado de ferramentas tridimensionais de projeto 164

Figura 58 - Comunicação em um empreendimento com extranet de projeto 165

Figura 59 - Pilares do desenvolvimento sustentável 167

Figura 60 - Escala de impacto dos desempenhos de edifícios. 171

Figura 61 - Projeto do Pearl River Tower e detalhe das turbinas eólicas 172

Figura 62 - Custo total de um edifício comercial em 50 anos 173

Figura 63 - Gradação dos impactos de custo e ambientais das alternativas para uso eficiente de recursos em edifícios de escritórios 175

Figura 64 - Importância dos itens avaliados em diversos métodos de avaliação sobre sustentabilidade 177

Figura 65 - Aplicação dos diversos métodos de avaliação

Figura 66 - Perfil mínimo de desempenho para certificação pelo processo AQUA 181

Figura 67 - Área de atuação da incorporadora pelo mundo 185

Figura 68 - Estrutura organizacional da incorporadora 186

Figura 69 - Estrutura organizacional do departamento de Projeto \& Construção da incorporadora 186

Figura 70 - Fases do processo de produção da incorporadora 187 
Figura 71 - Fluxo do processo da incorporadora da fase de concepção do produto

Figura 72 - Fluxo do processo da incorporadora da fase de desenvolvimento do projeto 190

Figura 73 - Fluxo do processo da incorporadora da fase de construção. 195

Figura 74 - Fluxo do processo da incorporadora da fase de manutenção. 196

Figura 75 - Conteúdo do Manual de Coordenação de Projetos da incorporadora.. 198 Figura 76 - Perspectiva ilustrada do empreendimento 1 ..................................200

Figura 77 - Planta tipo (zona baixa) de uma torre do empreendimento 1...............201

Figura 78 - Corte esquemático do empreendimento 1, indicando alturas e zoneamento vertical do andar tipo 202

Figura 79 - Arranjo entre os principais agentes do processo de projeto do

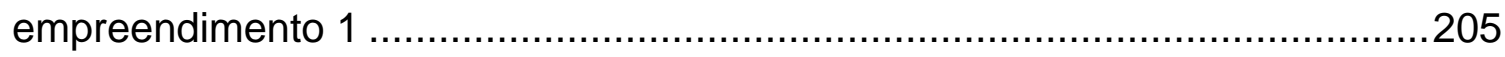

Figura 80 - Perspectiva ilustrada de uma torre do empreendimento 2 ..................206

Figura 81 - Planta tipo (zona baixa) de uma torre do empreendimento 2..............208 Figura 82 - Corte esquemático do empreendimento 2, indicando alturas e zoneamento vertical do andar tipo 208

Figura 83 - Arranjo entre os principais agentes do processo de projeto do empreendimento 2

Figura 84 - Perspectiva ilustrada do empreendimento 3 212

Figura 85 - Planta tipo (zona baixa) de uma torre do empreendimento 3. 213

Figura 86 - Corte esquemático do empreendimento 3 , indicando alturas e zoneamento vertical do andar tipo

Figura 87 - Arranjo entre os principais agentes do processo de projeto do empreendimento 3 217

Figura 88 - Paralelos entre fluxos de processos de projetos ................................220

Figura 89 - Fluxo do processo de Concepção do Produto do estudo de caso .......230 Figura 90 - Diretrizes do detalhamento da fase entre o Programa de Necessidades e o Plano de Massas 


\section{LISTA DE TABELAS}

Tabela 1 - Características das tipologias de núcleo em edifícios de escritórios 45

Tabela 2 - Requisitos de desempenho para vedações, e que podem ser aplicados à fachadas

Tabela 3- Características, vantagens e desvantagens de arranjos de pilares, vigas e lajes em concreto armado .73

Tabela 4 - Exemplos de sistemas prediais e subsistemas .79

Tabela 5 - Interfaces do Estudo Preliminar dos sistemas prediais e demais componentes do edifício 80

Tabela 6 - Temperaturas internas de conforto .84

Tabela 7 - Capacidade de tráfego de escadas rolantes 138

Tabela 8 - Espaços demandados para áreas técnicas do empreendimento 1 .......203

Tabela 9 - Projetistas e consultores do empreendimento 1 (em ordem alfabética de especialidade) 204

Tabela 10 - Espaços demandados para áreas técnicas do empreendimento 2 .....209

Tabela 11 - Projetistas e consultores do empreendimento 2 (em ordem alfabética de especialidade).

Tabela 12 - Espaços demandados para áreas técnicas do empreendimento 3, para uma torre

Tabela 13 - Projetistas e consultores do empreendimento 3 (em ordem alfabética de assunto) 


\section{LISTA DE ABREVIATURAS E SIGLAS}

ABNT

AdePT

AEDM

AFNOR

$\mathrm{AHU}$

ANAC

ANEEL

ANSI

AQUA

ASCE

ASHRAE

BEPAC

BIM

BOMA

BREEAM

CADD

CADES

CASBEE

CET

CFTV

$\mathrm{Cl}$
Associação Brasileira de Normas Técnicas

Analytical Design Planning Techniques

Architectural Engineering and Design Management

Association Française de Normalisation

Air Handling Unit

Agência Nacional de Aviação Civil

Agência Nacional de Energia Elétrica

American National Standards Institution

Alta Qualidade Ambiental

American Society of Civil Engineers

American Society of Heating, Refrigerating and Air Conditioning Engineers

Building Environmental Performance Assesment Criteria

Building Information Modeling

Building Owners and Managers Association

BRE Environmental Assesment Method

Computer Aided Design and Drafting

Conselho Municipal do Meio Ambiente e Desenvolvimento Sustentável

Comprehensive Assesment System for Building Environmental Efficiency

Companhia de Engenharia de Tráfego

Circuito Fechado de Televisão

Comitê de Investimento 
CIB

CII

CMMAD

COMAR

CONTRU

DC

DFD

DSM

EUA

GBt

GER

HK-BEAM

HQE

LEED

NBR

NFPA

P\&C

PCC

PERT-CPM

PMG

PMI

QAE

SARS

SBA

SBAT
International Council for Research and Innovation in Building and Construction

Construction Industry Institute

Comissão Mundial sobre Meio Ambiente e Desenvolvimento

Comando Aéreo Regional

Departamento de Controle de Uso de Imóveis

Desenvolvimento Comercial

Diagramas de Fluxos de Dados

Design Structure Matrix

Estados Unidos da América

Green Building tool

Gerência Regional do COMAR

Hong Kong Building Environmental Assesment Method

Haute Qualité Environnementale

Leadership in Energy and Environmental Design

Norma Brasileira

National Fire Protection Association

Projetos \& Construção

Departamento de Engenharia de Construção Civil

Project Evaluation Review Techniques - Critical Path Method

Preço Máximo Garantido

Project Management Institute

Qualidade Ambiental do Edifício

Severe Acute Respiratory Sindrome

Sustainable Building Alliance

Sustainable Building Assesment Tool 


$\begin{array}{ll}\text { SEHAB } & \text { Secretaria da Habitação } \\ \text { SGE } & \text { Sistema de Gestão Ambiental } \\ \text { SMT } & \text { Secretaria Municipal de Transportes } \\ \text { SPDA } & \text { Sistema de Proteção contra Descargas Atmosféricas } \\ \text { TGP } & \text { Tecnologia e Gestão da Produção } \\ \text { TI } & \text { Tecnologia da Informação } \\ \text { TIC } & \text { Tecnologia da Informação e Comunicação } \\ \text { TQM } & \text { Total Quality Management } \\ \text { USP } & \text { Universidade de São Paulo } \\ \text { VAV } & \text { Volume de Ar Variável } \\ \text { VRV } & \text { Volume de Refrigerante Variável } \\ \text { WGBC } & \text { World Green Building Council }\end{array}$




\section{LISTA DE SÍMBOLOS}

\begin{tabular}{|c|c|}
\hline $\mathrm{m}$ & metro \\
\hline$\%$ & porcentagem \\
\hline$m^{2}$ & metro quadrado \\
\hline lux & lux \\
\hline WWR & índice de área envidraçada de uma fachada \\
\hline $\mathrm{KN} / \mathrm{m}^{2}$ & quilo-Newtons por metro quadrado \\
\hline $\mathrm{Kgf} / \mathrm{m}^{2}$ & quilogramas-força por metro quadrado \\
\hline $\mathrm{p} / \mathrm{sf}$ & pounds per square feet (libras por pé quadrado) \\
\hline$w / m^{2}$ & watts por metro quadrado \\
\hline TR & tonelada de refrigeração \\
\hline${ }^{\circ} \mathrm{C}$ & graus Celsius \\
\hline $\mathrm{CO}_{2}$ & dióxido de carbono \\
\hline$m^{3}$ & metros cúbicos \\
\hline $\mathrm{m} / \mathrm{s}$ & metros por segundo \\
\hline $\mathrm{cm}$ & centímetros \\
\hline $\min$ & minutos \\
\hline 0 & graus \\
\hline
\end{tabular}




\section{SUMÁRIO}

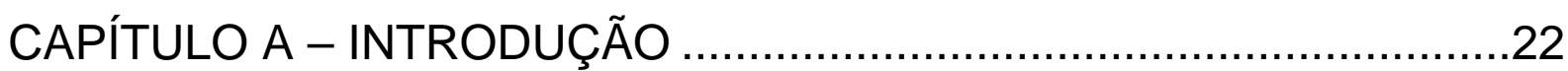

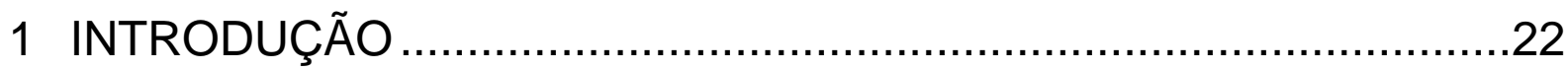

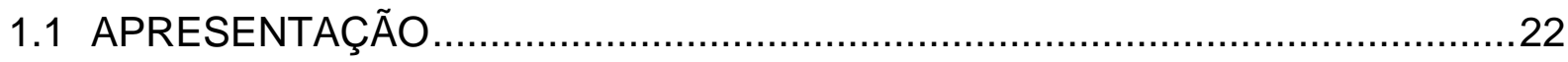

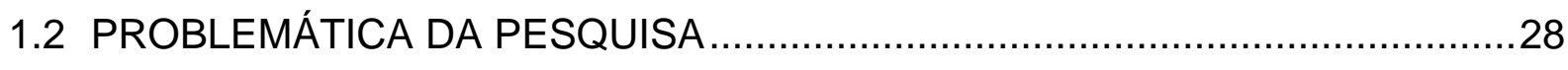

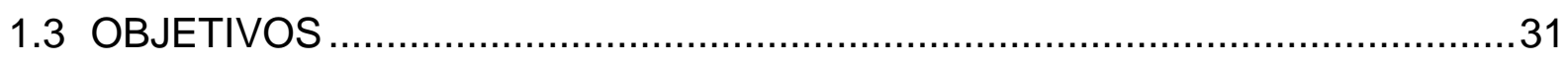

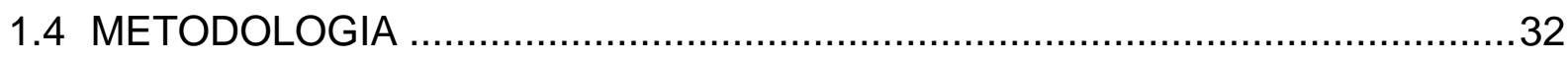

1.4.1 Considerações metodológicas / estruturação da pesquisa .........................32

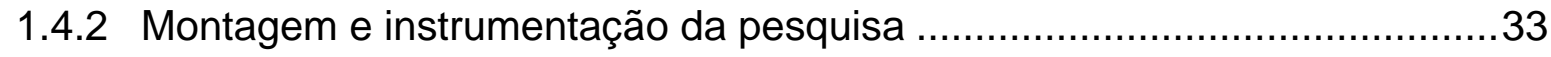

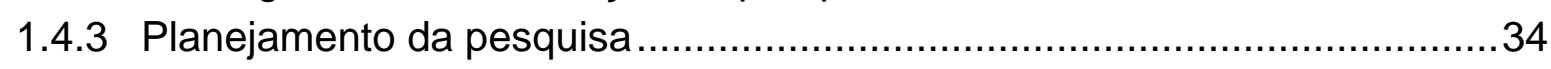

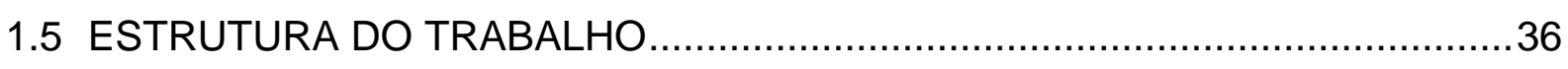

CAPÍTULO B - ESPECIALIDADES DE PROJETO ...........................37

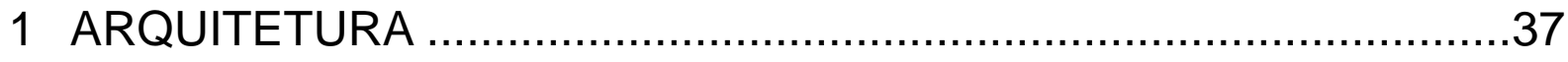

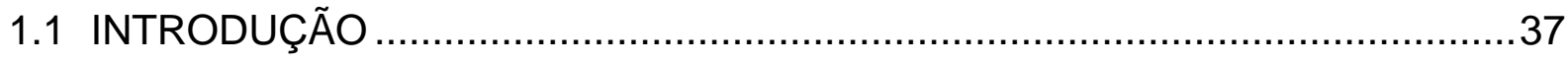

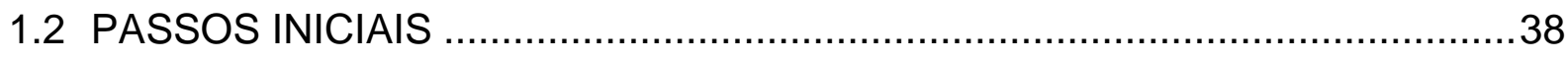

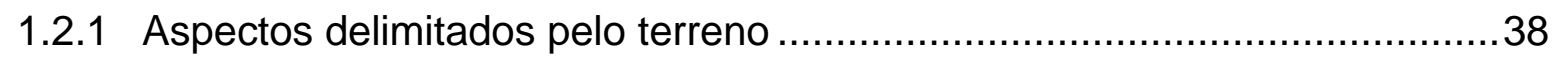

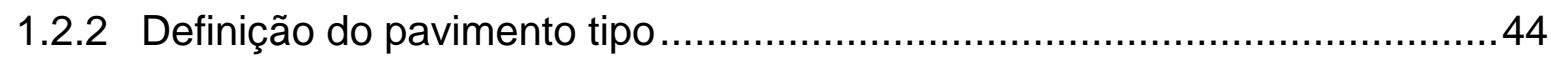

1.3 FACHADAS

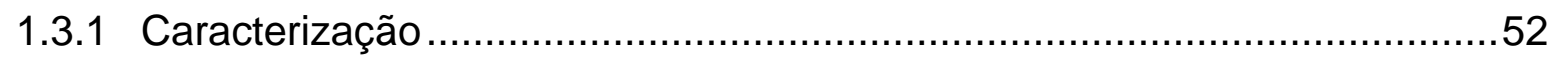

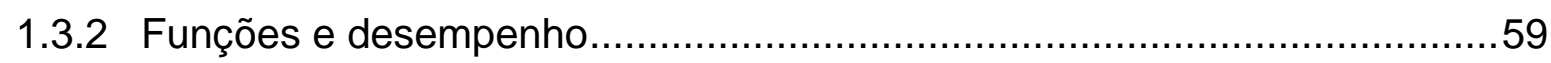

1.3.3 Importância das fachadas no conforto e sustentabilidade do edifício .........61

1.4 CLASSIFICAÇÃO MERCADOLÓGICA DOS EDIFÍCIOS DE ESCRITÓRIOS...66

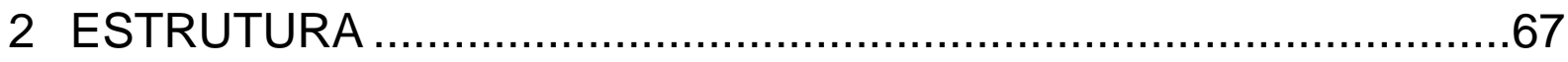

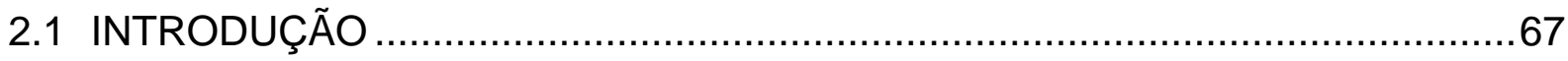

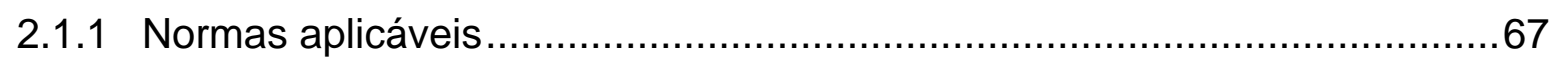

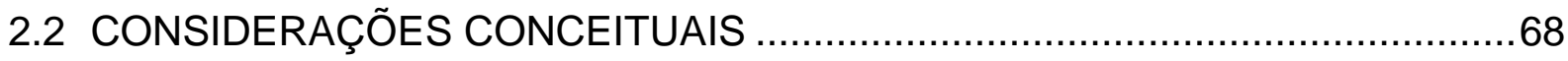

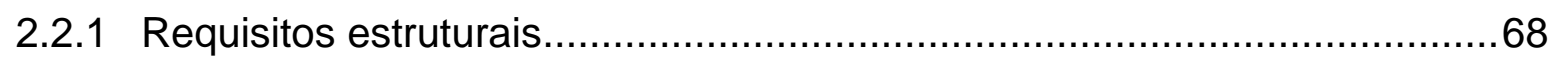

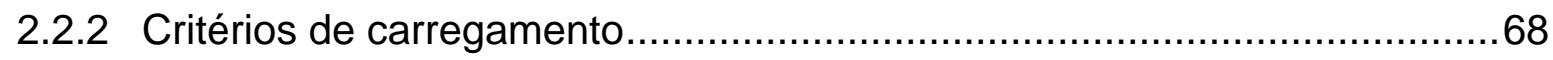

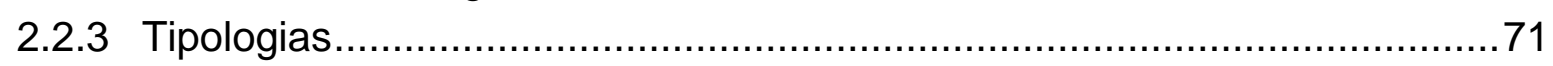

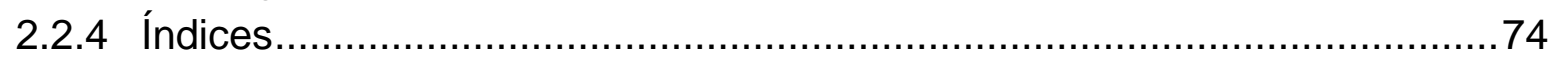

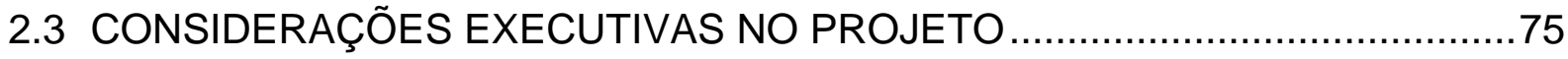

2.4 A ESTRUTURA NA CONCEPÇÃO DO EDIFÍCIO DE ESCRITÓRIOS...............76

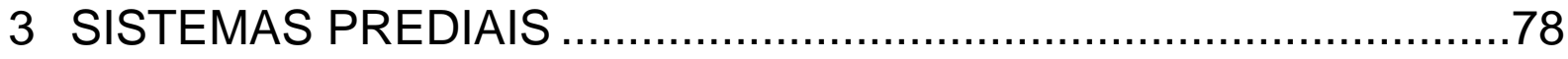

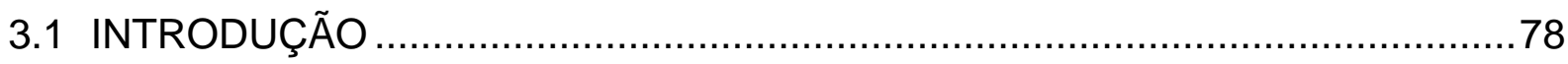




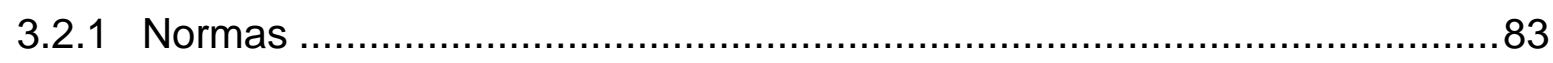

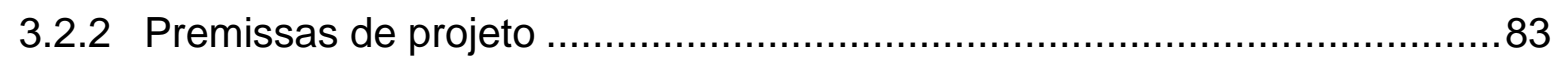

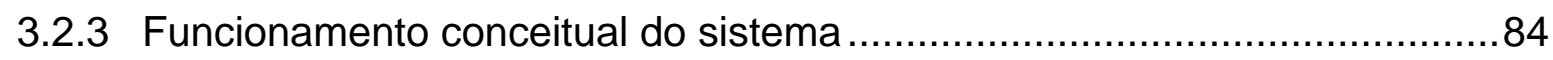

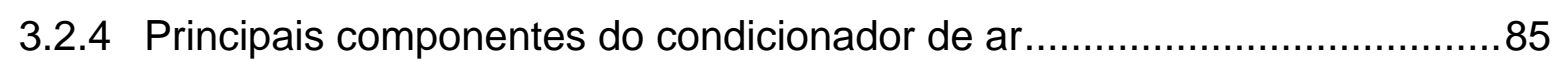

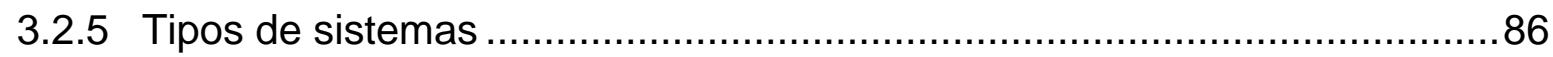

3.2.6 Componentes típicos e demanda de espaços ......................................... 89

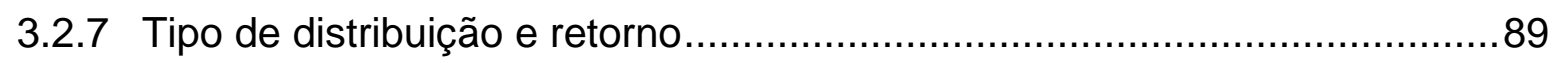

3.2.8 Impacto no consumo de energia elétrica ..............................................92

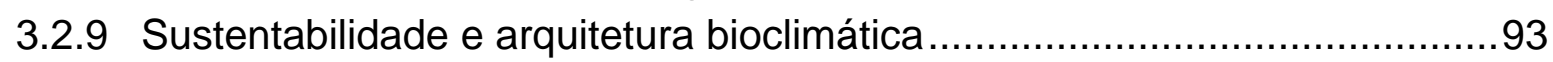

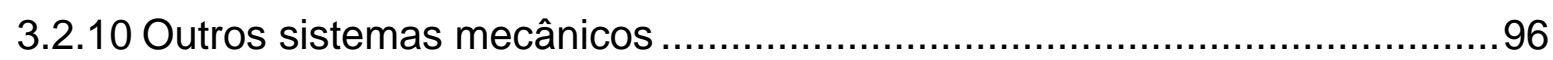

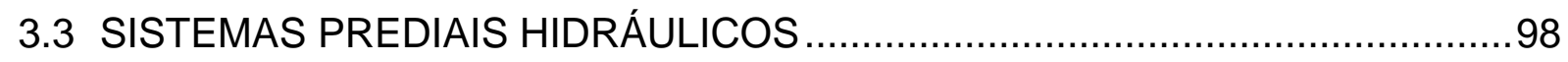

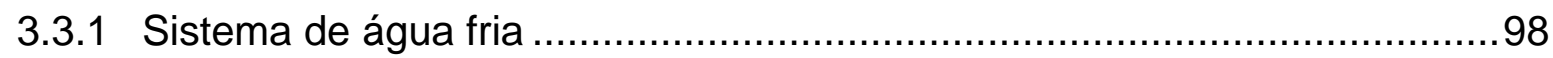

3.3.2 Sistema de água quente e gás combustível ........................................103

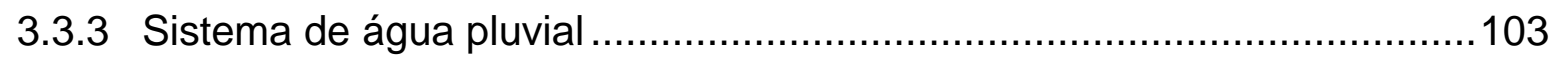

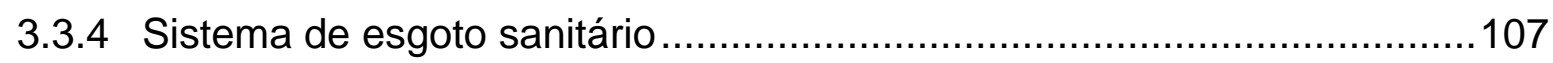

3.3.5 Sistema de proteção contra incêndio ………......................................110

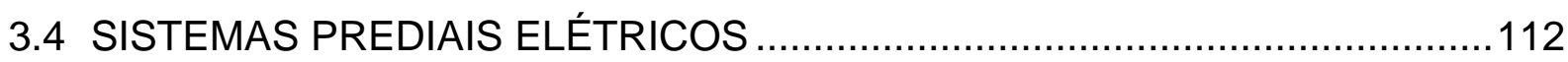

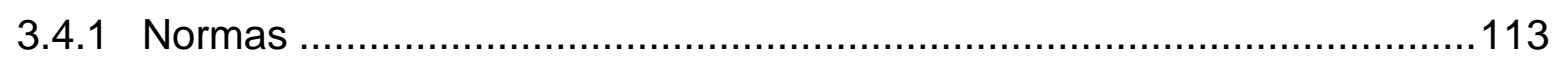

3.4.2 Entrada e medição de energia .......................................................113

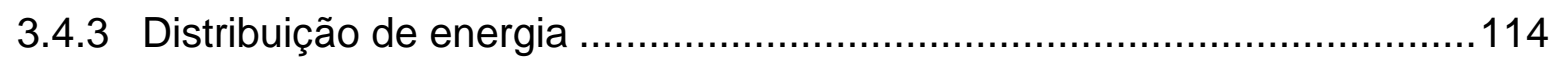

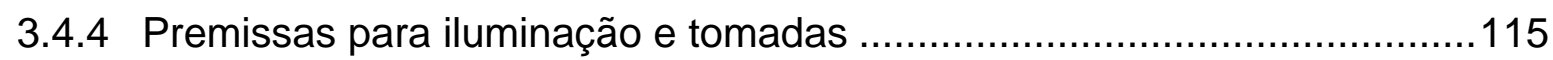

3.4.5 Sistemas de geração de energia própria ................................................116

3.4.6 Aterramento predial e proteção contra descargas atmosféricas ...............118

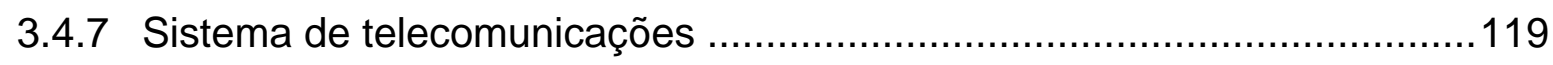

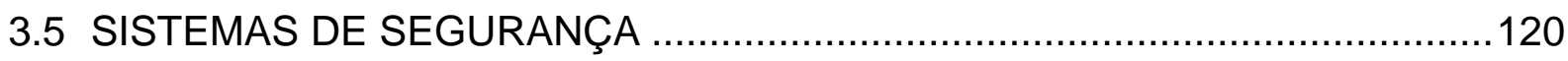

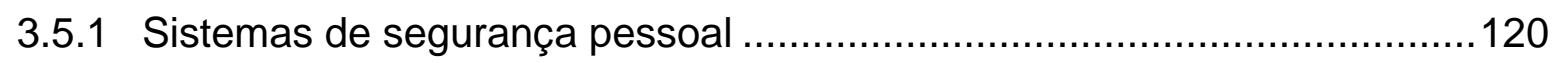

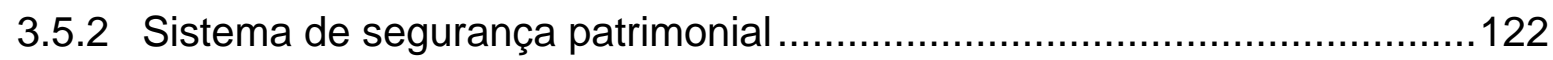

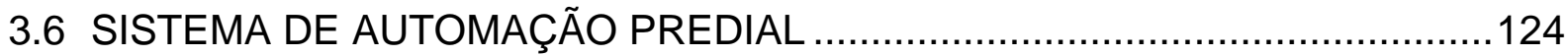

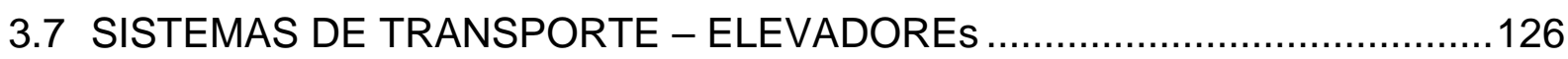

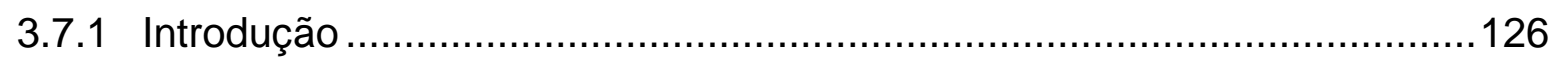

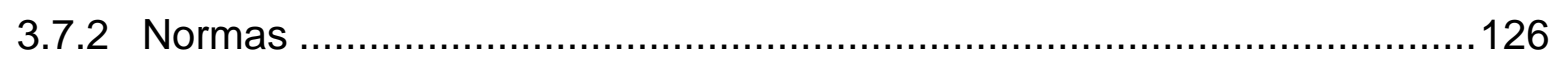

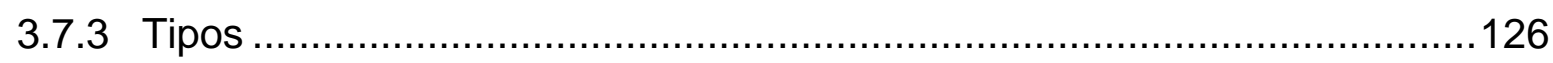

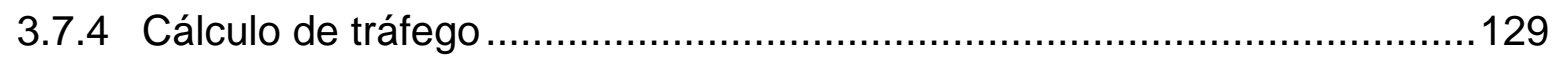

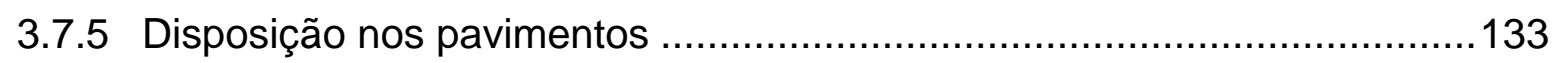

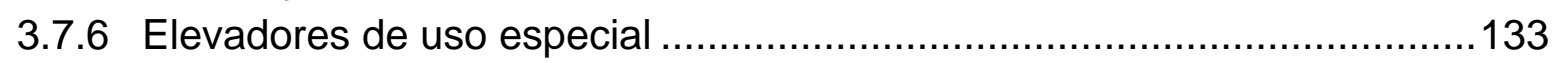

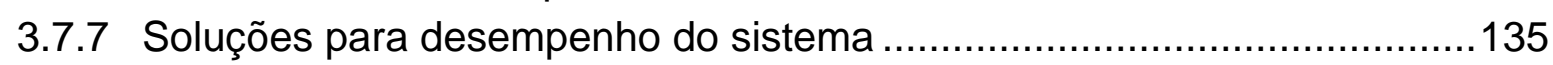

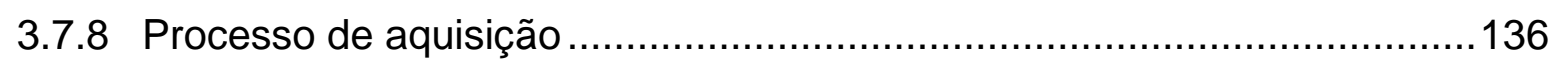

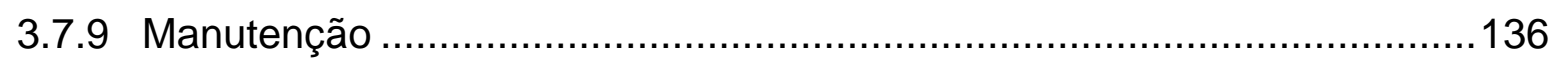


3.7.10 Escadas rolantes.

CAPÍTULO C - ASPECTOS DE GESTÃO ....................................139

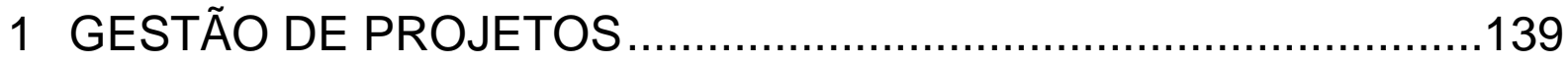

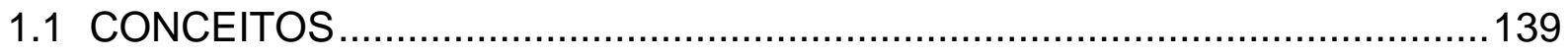

1.2 PLANEJAMENTO DO PROCESSO DE PROJETO ....................................141

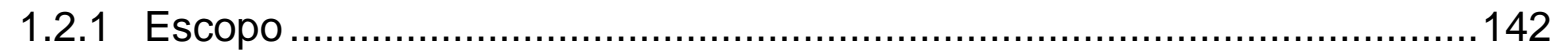

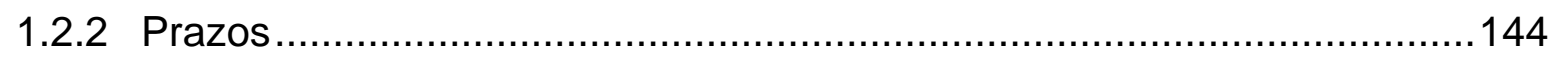

1.2.3 Agentes envolvidos e configuração de equipes ...................................145

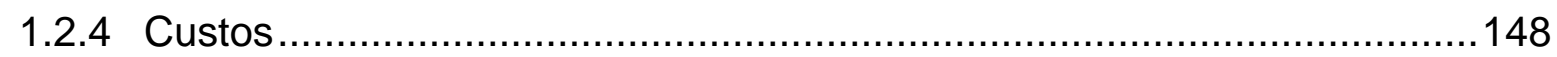

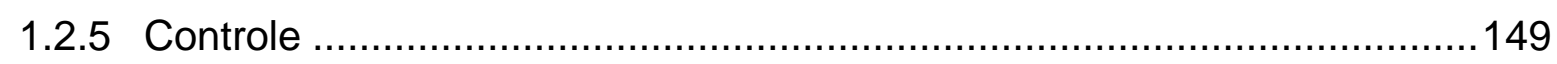

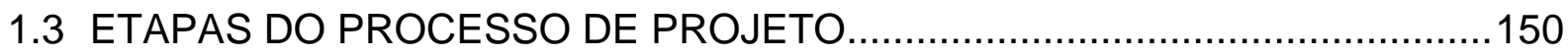

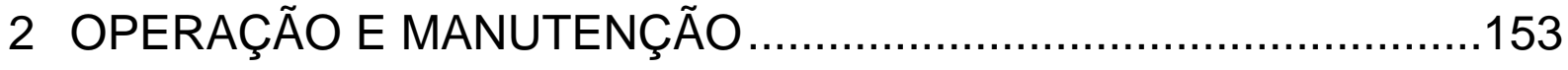

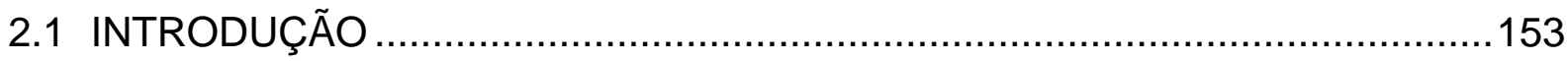

2.2 INFLUÊNCIA DA CONCEPÇÃO DOS SISTEMAS PREDIAIS .......................155

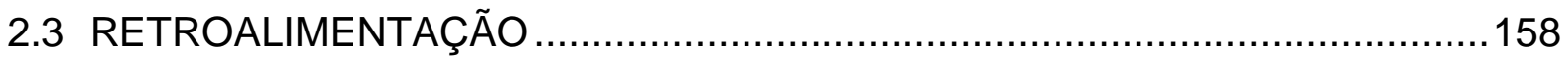

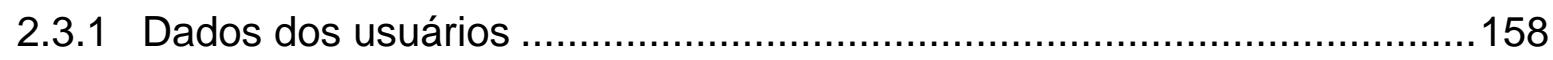

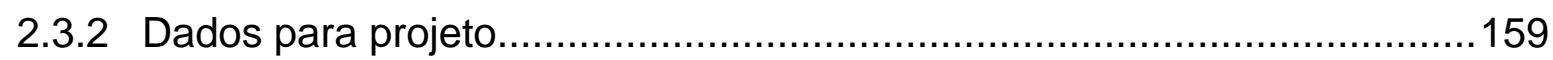

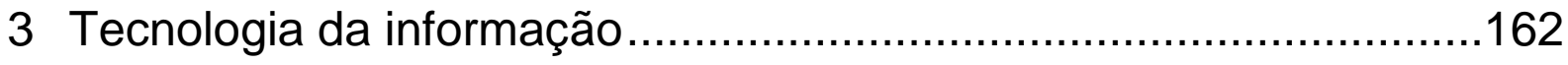

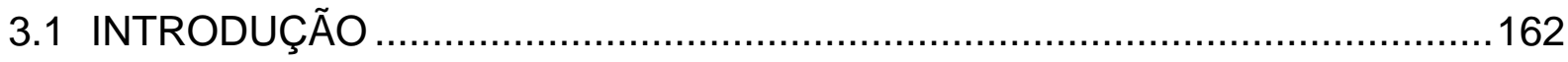

3.1.1 Ferramentas de cálculo e modelagem tridimensional .............................162

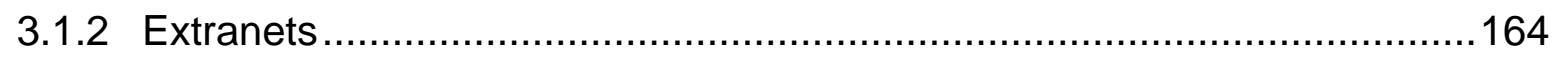

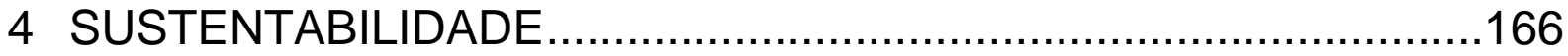

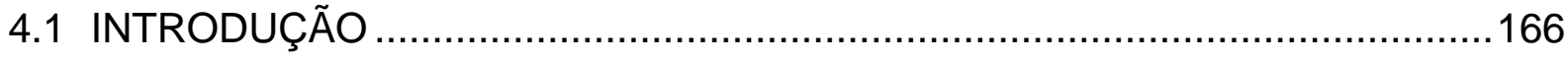

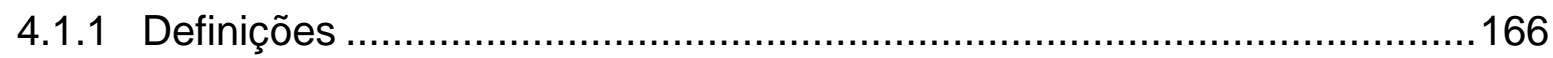

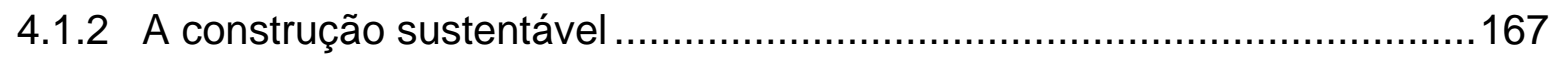

4.1.3 Dados de consumo da indústria da construção ......................................168

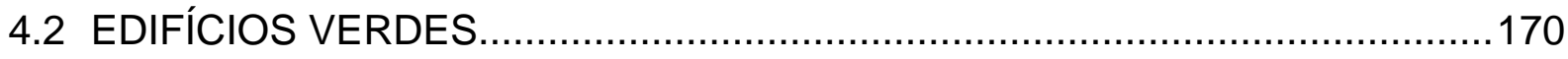

4.3 O CICLO DE VIDA DA EDIFICAÇÃO SOB A ÓTICA DO EMPREENDEDOR.173

4.4 ENTIDADES RELACIONADAS AO TEMA NO setor da construção................176

4.5 DESCRIÇÃO DOS MODELOS DE AVALIAÇÃO "LEED" e "AQUA" .................178

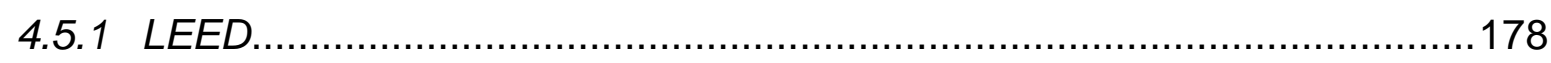

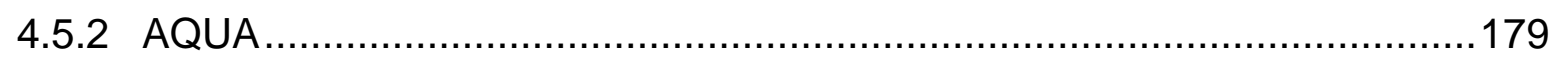

4.5.3 Análise comparativa dos sistemas de avaliação.......................................182

4.6 CONSIDERAÇÕES SOBRE O ASSUNTO …..............................................183

CAPÍTULO D - ESTUDO DE CASO ........................................185

1 APRESENTAÇÃO ............................................................ 185 


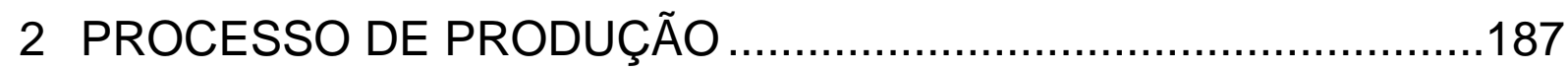

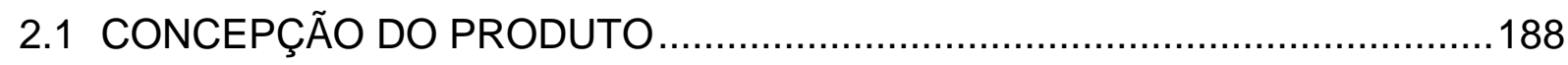

2.2 DESENVOLVIMENTO DO PROJETO ………………………………...... 190

2.2.1 Projeto Preliminar...............................................................................190

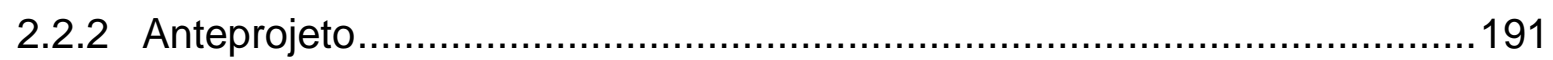

2.2.3 Projeto Básico ……………………………………………………........

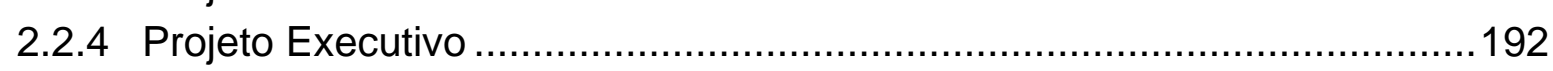

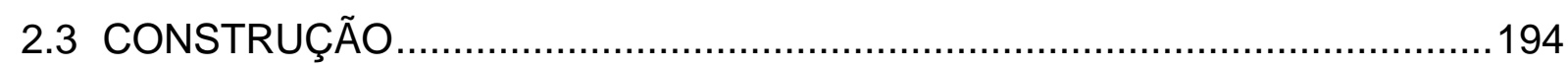

2.4 OPERAÇÃO E MANUTENÇÃO ..................................................................196

3 FERRAMENTAS PARA O PLANEJAMENTO DO PROCESSO DE

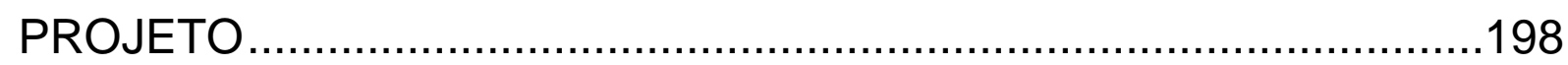

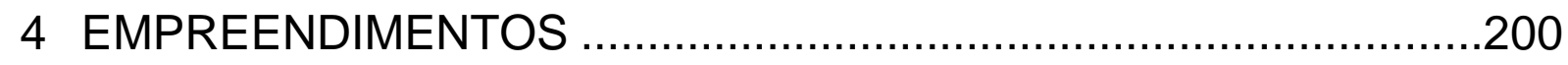

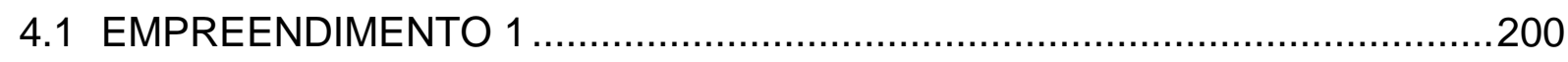

4.1.1 Dados técnicos …………………………………………………...201

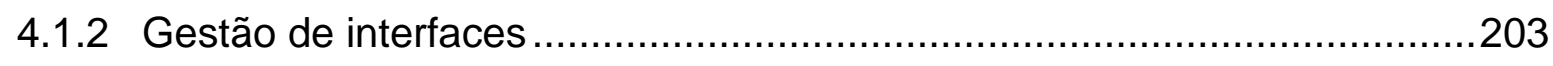

4.1.3 Certificação ambiental........................................................................20

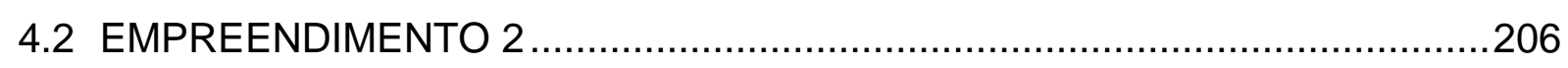

4.2.1 Dados técnicos ………………………………………………….....207

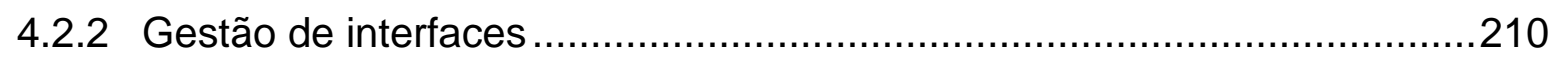

4.2.3 Certificação ambiental...........................................................................211

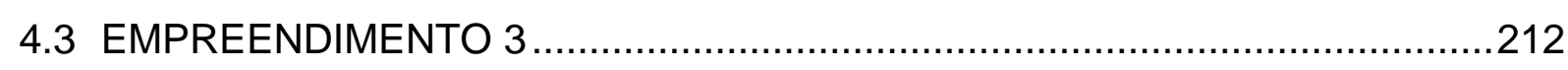

4.3.1 Dados técnicos do pavimento tipo ……………………………………....213

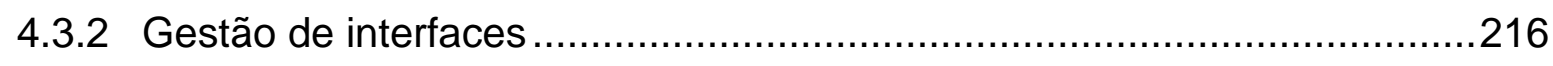

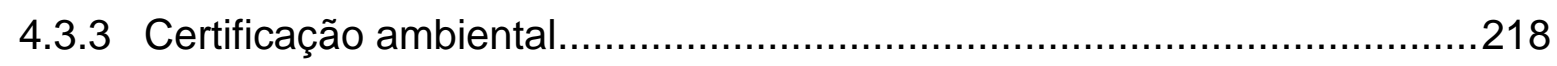

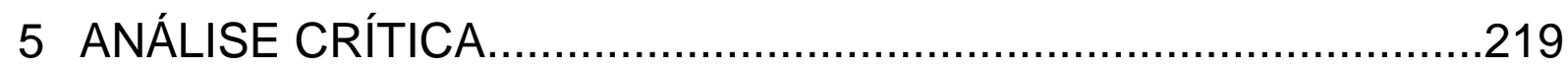

5.1 ANÁLISE DO PROCESSO ……………………………….......................219

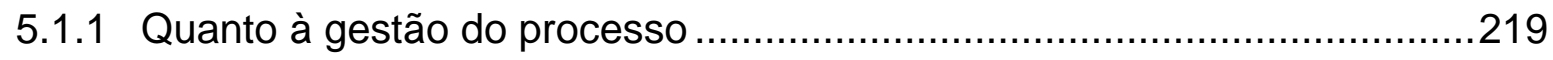

5.1.2 Quanto às etapas do processo ………………………………….....220

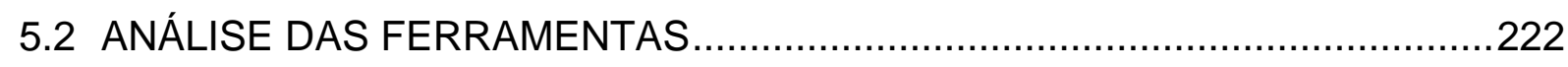

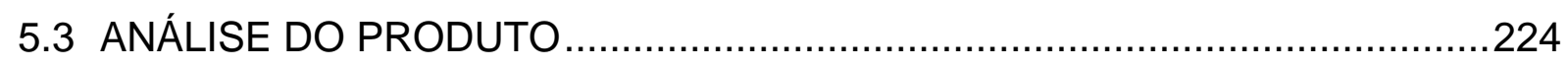

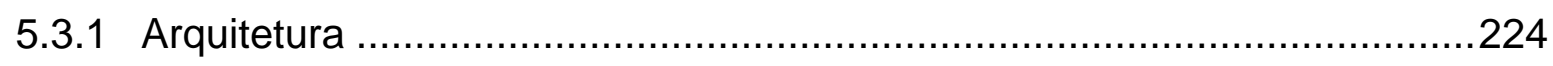

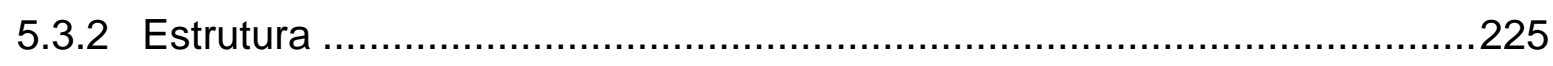

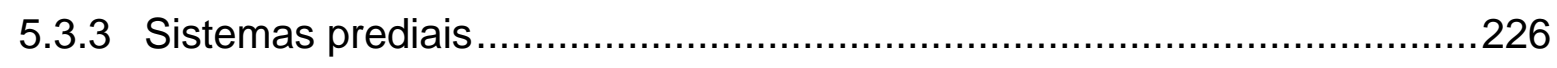

5.4 CONSIDERAÇÕES SOBRE O ESTUDO DE CASO ……………………....228

5.5 DIRETRIZES PARA O PLANO DE MASSAS ……………........................230

CAPÍTULO E - CONSIDERAÇÕES FINAIS ....................................23 
1 CONSIDERAÇÕES SOBRE OS RESULTADOS DA PESQUISA ...233

1.1 ATENDIMENTO AOS OBJETIVOS DA PESQUISA …...............................234

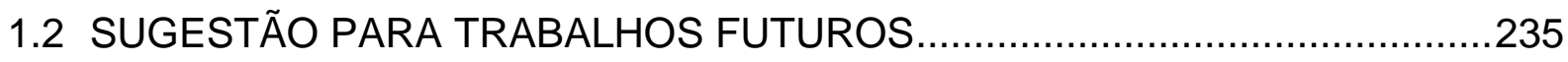

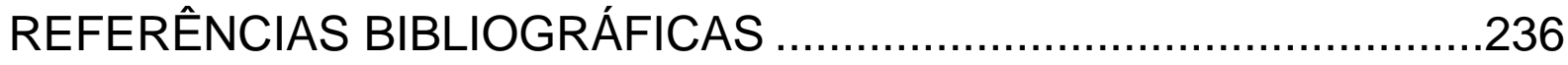




\section{CAPÍTULO A - INTRODUÇÃO}

\section{INTRODUÇÃO}

\subsection{APRESENTAÇÃO}

Os assuntos já desenvolvidos e que ainda podem ser objeto de estudo relacionado ao tema edifício de escritórios são vastos, pela natureza diversa dos agentes que o afetam ou são por ele afetados (investidores, empreendedores, construtores, projetistas, administradores prediais e usuários), e as inúmeras possibilidades de enfoque que o tema permite (histórico, de gestão, econômico e técnico, entre outros).

No Brasil, os edifícios de escritórios vistos como produto imobiliário constituem um segmento importante no mercado, principalmente nas grandes metrópoles, devido à expansão do setor terciário (de serviços). Segundo relatório da Jones Lang LaSalle (2009), o total de área de escritórios em estoque, no Brasil, corresponde a cerca de 25 milhões de metros quadrados, sendo que 60\% deste total localiza-se em São Paulo e no Rio de Janeiro. Além disso, estas duas cidades contam com uma proporção ainda maior de escritórios de alto padrão mercadológico ${ }^{1}$ em relação ao restante do país: $60 \%$ dos escritórios de alto padrão estão em São Paulo, enquanto que $20 \%$ encontram-se no Rio de Janeiro. No mercado local, os escritórios de alto padrão correspondem a $27 \%$ do total de área de escritórios em São Paulo e $20 \%$ no Rio de Janeiro. De acordo com a mesma fonte, o mercado de edifícios de escritório ainda é relativamente pequeno no Brasil, se comparado com as proporções de tamanho e de economia do país, sugerindo um potencial crescimento deste segmento imobiliário.

As referências bibliográficas sobre os edifícios de escritórios brasileiros com ênfase na produção arquitetônica aparecem em arquitetos autores de projeto, tais como: Botti \& Rubin (2002, 2009), Aflalo \& Gasperini ${ }^{2}$ (AFLALO; VIANNA, 1999, OLIVATO, 2004) e Carlos Bratke (BRATKE; MAIA; WISSENBACH, 1995, PUGLIESE, 2005). Outros estudos sobre edifícios de escritórios são relacionados a algum direcionamento específico, tais como: histórico (AMARAL, 1995, ANDRADE, 2007, FIALHO, 2007), aspectos de conforto (FROTA; SCHIFFER, 1999, CHVATAL; LABAKI; KOWALTOWSKY, 1998), avaliação pós-ocupação

\footnotetext{
${ }^{1}$ Ver seção 1.3 do capítulo B.

${ }^{2}$ A formação original do escritório era Croce, Aflalo e Gasperini.
} 
(ORNSTEIN; ROMÉRO, 1992, ANDRADE, 2005) e sistemas prediais específicos, como automação (LEITE, 1997, VASCONCELOS, 2005, MARTE, 1995, CASTRO NETO, 1991) e ar condicionado (LEITE, 2003).

As referências sobre os edifícios de escritório internacionais também trazem abordagens específicas. No enfoque histórico, a invenção do freio de segurança para elevadores por Elisha Otis, em 1852 (SANTOS, A. B., 2007), combinado com o desenvolvimento de estruturas que não dependiam das paredes de vedação e a evolução dos sistemas de proteção contra fogo, permitiu o surgimento das tipologias modernas dos edifícios de escritórios com múltiplos pavimentos. A produção de edifícios significativos desta natureza nos EUA no começo do século XX fez parte fundamental da história deste tipo de edificação, destacando-se a escola de Chicago $^{3}$ e os arranha-céus de Nova lorque, com diversos exemplares com mais de 50 andares e fortemente influenciados pela especulação imobiliária. Heinle e Leonhardt (1989) referem-se à expressão que o Reverendo S. Parker Cadman utilizou para o Woolworth Building (214m de altura) em 1913: "catedral do comércio", em alusão comparativa entre o monopólio da religião na Idade Média e o monopólio do comércio nos Estados Unidos no séc. XX.

A vertente norte-americana foi uma das duas principais correntes de concepção de projeto de escritórios consideradas relevantes por Duffy (1999). Suas características principais foram regidas pelo desenvolvimento de edifícios de uso genérico, decorrentes da prática dos investidores imobiliários em raciocinar sobre a multiplicação do valor do terreno pelo número de andares do edifício, para tornar o valor investido em negócio rentável.

A outra corrente de concepção tratou da tradição do norte europeu, que, por diferenças históricas e políticas, contou muito pouco com a figura do investidor imobiliário. As empresas desenvolveram os edifícios para uso próprio (edifícios customizados) e a forte presença dos sindicatos trabalhistas na negociação de condições ambientais de trabalho foi determinante na prevalência do princípio do bem-estar. O resultado apareceu em edifícios estreitos (para garantir luz natural a todos), altamente celulares e ambientalmente corretos, porém ineficientes em termos de planejamento de espaços.

Os conceitos dos espaços de trabalho, por sua vez, podem ser classificados em quatro principais, de acordo com a distribuição das pessoas e da organização empresarial: colméia, célula, alcova e clube (DUFFY, 1999). Estes conceitos podem ser relacionados

\footnotetext{
${ }^{3} \mathrm{O}$ termo escola de Chicago refere-se aos protagonistas dos acontecimentos relacionados à arquitetura e urbanismo da reconstrução da cidade de Chicago no início do séc.XX, após o incêndio de 1871, marcados pela proliferação de arranha-céus, especulação imobiliária, e caráter unitário dos edifícios. De acordo com Benevolo (1976), destacam-se os seguintes arquitetos: Willian Le Baron Jenney, Willian W. Boyngton, Daniel H. Burnham, Willian Hollabird, Martin Roche e Louis Sullivan. Frank L. Wright é considerado "herdeiro" e vanguardista desta escola.
} 
historicamente a aspectos do cenário político-econômico dos últimos 100 anos e a modelos de gestão das empresas (ANDRADE, 2007):

- No início do séc. XX, o taylorismo, pautado no modelo da fábrica e com o conceito de ocupação bull pen (arranjo rígido, com as mesas dispostas em fileiras - Figura 1);

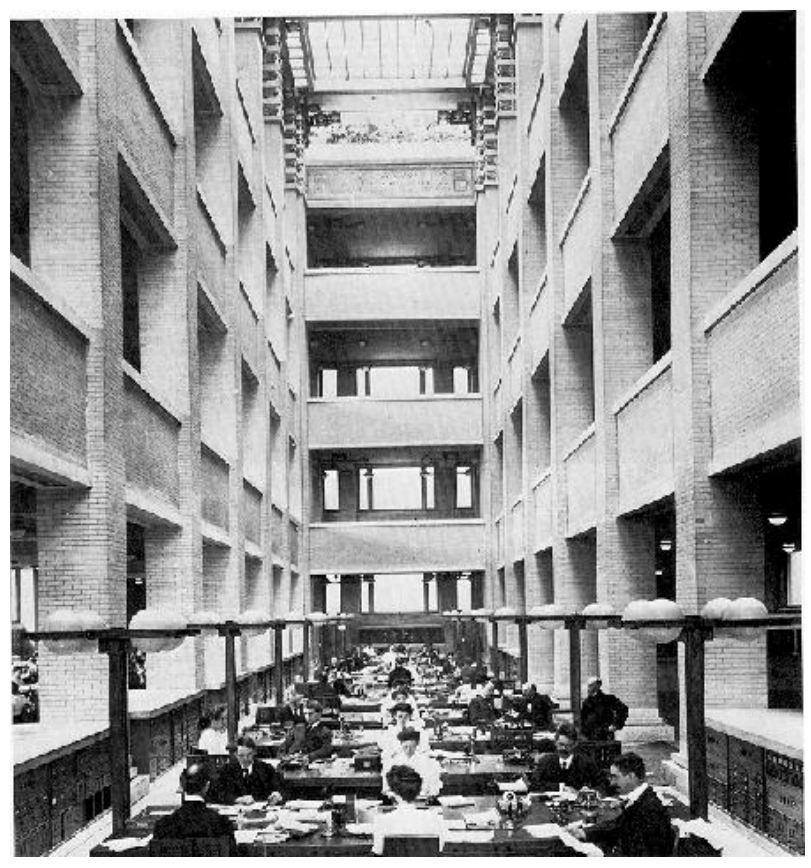

Figura 1 - Vista interior do edifício Larkin (EUA), construído em 1904 e demolido em 1949

Fonte: Haeber, J. (sem data)

- Na época do pós-guerra, o pós-fordismo, na administração por objetivos e com o conceito de ocupação de escritórios panorâmicos (landscape office - Figura 2) derivado do conceito de planta livre (open plan), mas com a preocupação principal sobre os fluxos de comunicação da empresa;

- Na década de 70, o conceito de qualidade total (TQM $\left.{ }^{4}\right)$, envolvendo maior preocupação com a privacidade dos indivíduos nas soluções de planta livre, por meio de estações de trabalho (Figura 3);

- Na década de 80, a busca da excelência, com o foco no negócio principal das empresas e com a terceirização dos serviços, com o arranjo de espaços refletindo esta complexidade por meio dos escritórios territoriais (que podem ser fechados ou abertos);

\footnotetext{
${ }^{4}$ Total Quality Management - Gestão da Qualidade Total
} 


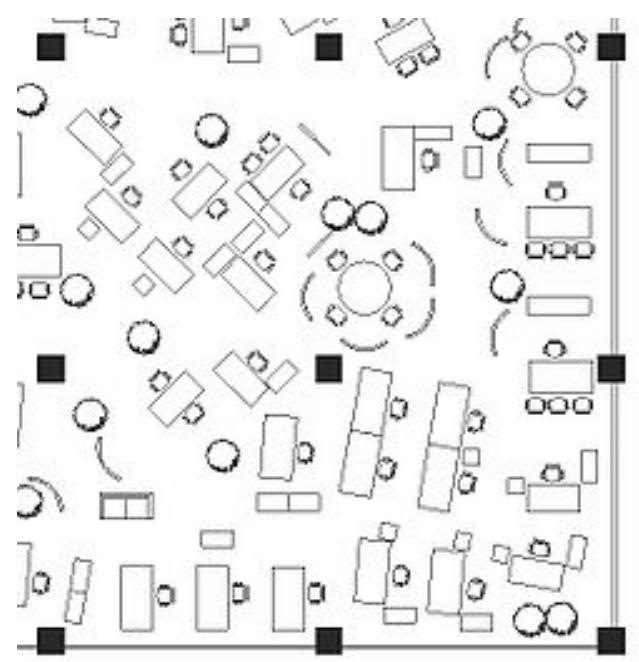

Figura 2 - Representação parcial de um escritório panorâmico

Fonte: http://en.wikipedia.org/wiki/Office_landscape

- E na década de 90 em diante, com a reengenharia, globalização e internet, os escritórios não territoriais, que tratam de diversas formas de organizar grupos de trabalho, incluindo o trabalho em casa (home office).

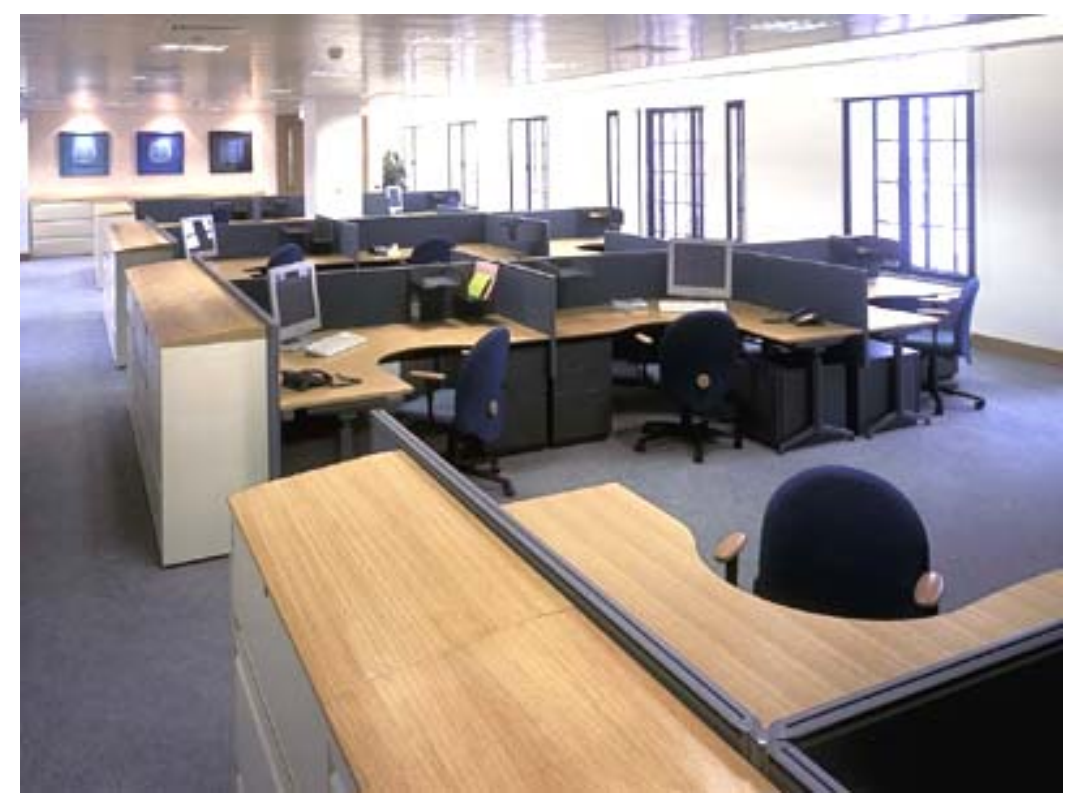

Figura 3 - Sistemas modulares para individualização das estações de trabalho Fonte: http://www.hermanmiller.com.br/our-business/bank-of-england-london/ 
No enfoque da gestão é possível relacionar as conseqüências das diferentes abordagens que o projeto permite sobre os usuários e as organizações, destacando-se, nesta linha, estudos de Becker e Steele (1995). A visão do funcionamento do ambiente de trabalho levado ao seu melhor desempenho também é uma abordagem relevante, por considerar questões de eficiência, adequação e adaptação do espaço, que fornecem subsídios para projetos. Esta abordagem (ELEY; MARMOT, 1995) enfatiza a importância e a visão do administrador predial neste tipo de edifício. Este agente é o que representa os interesses dos usuários finais, normalmente desconhecidos quando o edifício é concebido como produto imobiliário sem o ocupante final definido.

Por sua vez, nos edifícios customizados, onde o usuário final é também o empreendedor, Kaya (2004) verifica que não só é desejável que estes interesses estejam expressos no programa de necessidades de projeto, mas também que a participação ativa destes usuários na concepção do mesmo permite um retorno do investimento, por meio de valor incorporado ao desempenho do negócio, maior do que se não tivesse havido esta participação. Nesta mesma linha de raciocínio, Arge (2005) observa que os edifícios customizados apresentam maior adaptatibilidade de uso do que a se obtém nos edifícios projetados por empreendedores que só desenvolvem e operam os empreendimentos, e maior ainda, do que aquela que se verifica nos edifícios projetados por aqueles que apenas vendem o empreendimento.

No enfoque técnico, existem manuais para a projetação de edifícios de escritório de diferentes épocas, coerentes com o cenário político-econômico vigente e mostrando, indiretamente, a evolução dos diversos itens que compõem este tipo de edificação: organização espacial, estrutura, materiais, sistemas prediais, envoltória (fachadas) e sistemas de informação. Nesta linha, podem ser mencionados trabalhos de Rosenauer (1955), Manning (1965), Schmertz (1975) e Crane e Dixon (1991). Com destaque especial, aparecem Duffy; Cave e Worthington (1980) e Duffy (1999), que estudam em profundidade a ocupação do espaço de trabalho e seu reflexo no projeto, e Kohn e Katz (2002), que tratam do edifício e de seus subsistemas, na visão dos especialistas de cada área.

A evolução das tecnologias construtivas, de gestão e de sistemas prediais, aliada à percepção de que o edifício de escritórios passa a ter funções mais complexas do que simplesmente dar suporte às atividades de serviço - entre elas, a influência no desenvolvimento dos negócios -, extrapola os limites do enfoque puramente técnico para este tipo de projeto. Considerando as necessidades atuais de uso racional das fontes não renováveis de energia e matérias-primas, ligadas aos aspectos de mudanças climáticas e sustentabilidade, a abordagem para um manual de projetos de edifícios de escritório passa 
a ser mais complexa. No aspecto do projeto sustentável de edifícios, visões mais pragmáticas são abordadas por Frej et al. (2005) e Mendler; Odell e Lazarus (2006), mas a visão holística de todo o processo, no qual projeto e sustentabilidade estão envolvidos, é feita por Yeang (2006).

No enfoque urbano, os edifícios de escritório são comumente associados aos arranha-céus das grandes regiões metropolitanas. Heinler e Leonhardt (1989) sustentam que o objetivo dos construtores e arquitetos deste tipo de edificação é dar forma à expressão arquitetônica, criar confiança na empresa que constrói a estrutura, e, ao mesmo tempo, expressar grandiosidade, prosperidade e poder. O alcance bem sucedido deste objetivo reflete-se nos edifícios que são considerados ícones nas cidades (Figura 4), e que acabam sendo utilizados como pontos de referência. Não à toa, o emblemático ataque de 11 de setembro ocorreu em um complexo de edifícios de escritórios, o World Trade Center, em uma clara referência ao significado simbólico de se atingir o centro financeiro norte-americano.

O enfoque proposto para este trabalho trata do estudo que reúne os aspectos técnicos com os de gestão para o desenvolvimento de projetos de edifícios de escritórios como produto imobiliário, considerando as condições culturais brasileiras, lacuna sobre o qual a pesquisa pretende reduzir.

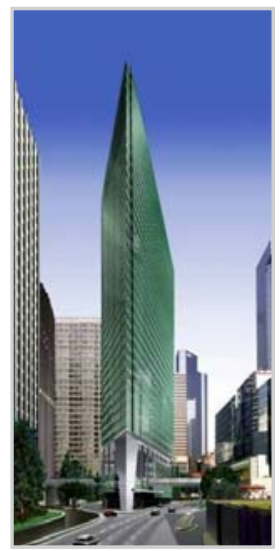

CBX Tower Paris, França
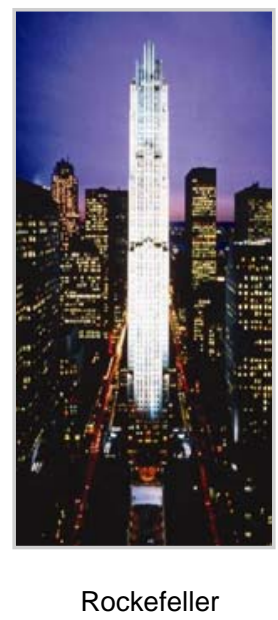

$$
\text { Center }
$$
New York, EUA

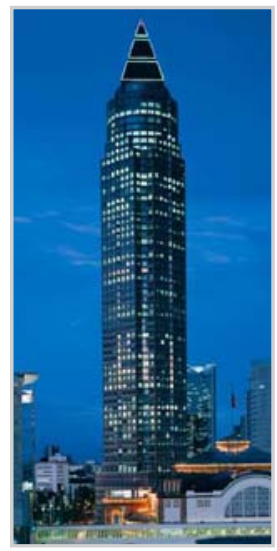

MesseTurm

Frankfurt,

Alemanha
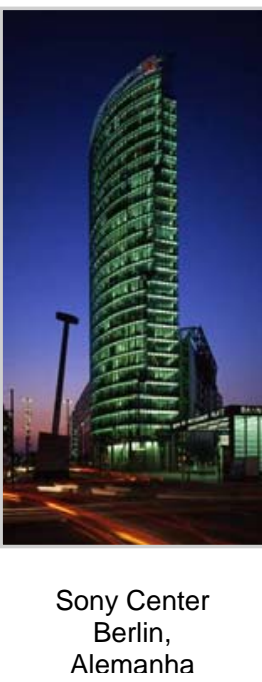

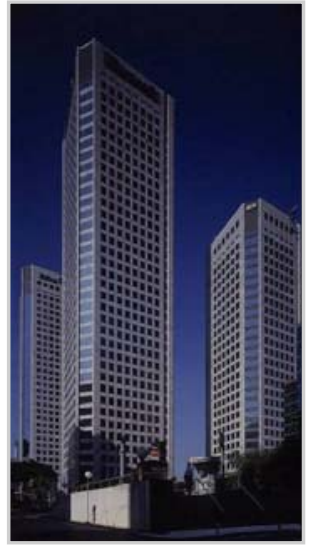

Torre Norte

São Paulo, Brasil

Figura 4 - Alguns edifícios de escritório considerados como ícones, em diferentes regiões 


\subsection{PROBLEMÁTICA DA PESQUISA}

Este trabalho vincula-se à linha de pesquisa de Gestão de Projetos e Sistemas de Gestão desenvolvida pelo Grupo de Tecnologia e Gestão da Produção na Construção Civil (TGP) do Departamento de Engenharia de Construção Civil da Escola Politécnica da Universidade de São Paulo (PCC-USP). Os trabalhos deste grupo têm procurado caracterizar as transformações recentes das práticas de gestão e das tecnologias construtivas da indústria da construção civil e proposto conceitos e modelos para seu aprimoramento, em todos os componentes da cadeia produtiva.

Assim, esta pesquisa trata do processo do projeto de edificações e, em especial, as etapas iniciais deste processo, com enfoque específico para os edifícios de escritórios.

O conceito da influência do projeto no resultado da construção e operação de empreendimentos é bem conhecido, tanto nos meios acadêmicos, quanto pelos profissionais de mercado, há, pelo menos 20 anos. O gráfico proposto (Figura 5) pelo grupo do Construction Industry Institute - CII - é amplamente utilizado, com variações no formato, em escolas de engenharia e em apresentações de consultorias para empresas.

É de se esperar, portanto, que as etapas de estudo de viabilidade e de projeto estejam sendo desenvolvidas de maneira consistente com a importância que têm em relação ao processo como um todo. Infelizmente, no mercado imobiliário, a constatação é outra: o processo do negócio faz que o estudo de viabilidade seja basicamente feito de forma analítica por agentes comerciais. Os projetos, por sua vez, são contratados da mesma forma que os serviços de construção, ou seja, por "pacotes fechados" (entregas de desenhos), para atendimento às duas fases consideradas cruciais pelos empreendedores: o projeto legal, que antecede a comercialização do empreendimento, e o projeto executivo, que antecede a construção (MANZIONE, 2006). Esta dinâmica do mercado imobiliário resulta no trabalho de concepção do projeto como uma interação quase que exclusiva entre o empreendedor e o arquiteto autor do projeto. 


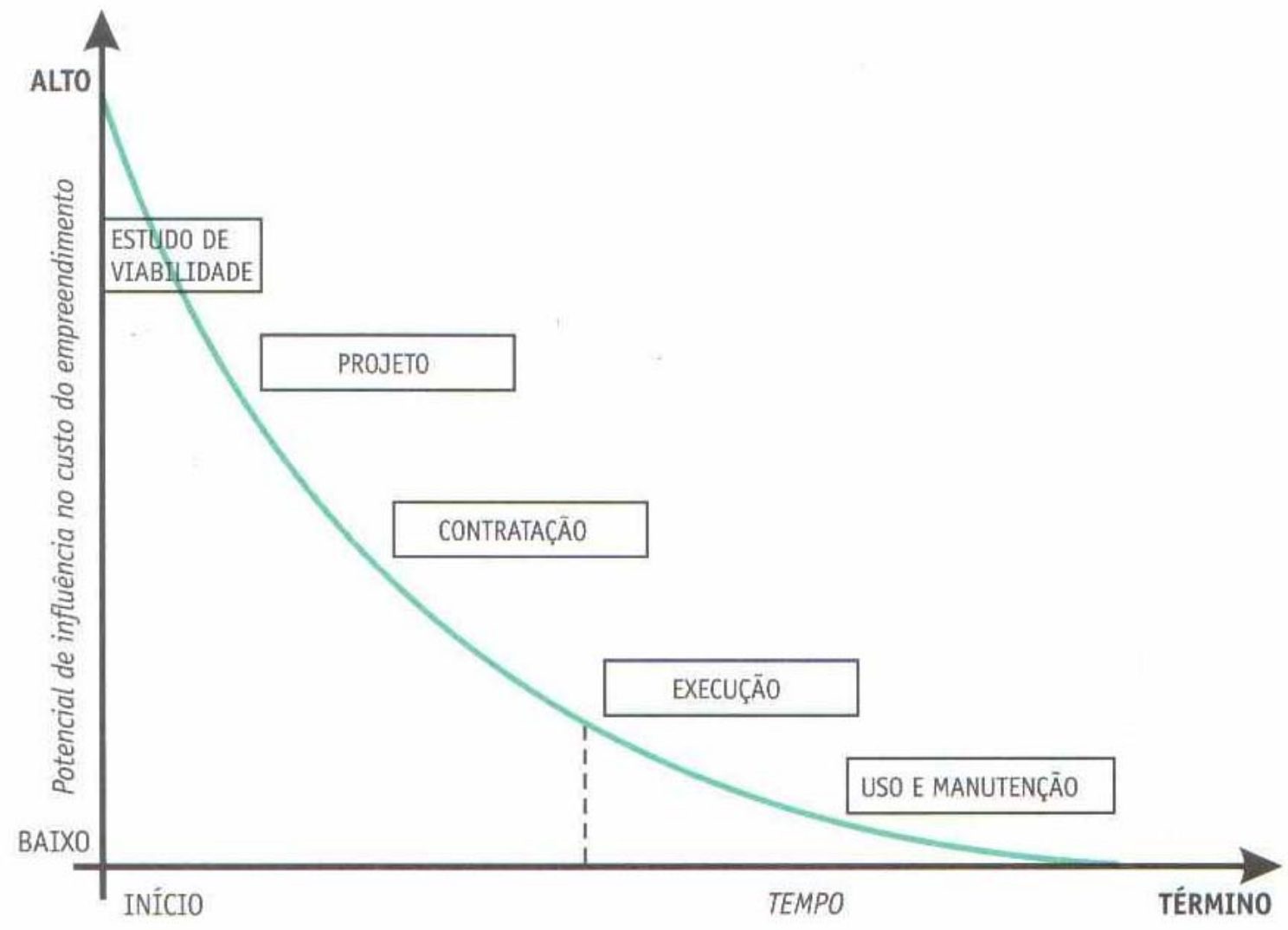

Figura 5 - Potencial de influência no custo final de um empreendimento e suas fases

Fonte: CII (1987) apud Melhado (2005)

Esta interação pode funcionar relativamente bem para os empreendimentos residenciais de até certo padrão, cujos requisitos de desempenho são amenizados e de domínio do conhecimento do arquiteto. Porém, em edifícios de escritórios, as exigências de desempenho são maiores, pela própria natureza do mercado, e os sistemas prediais, mais complexos e em constante evolução. O próprio planejamento dos espaços deste tipo de edificação envolve um estudo aprofundado da previsão de como ele será ocupado ao longo de sua vida útil, que pode ser algo em torno dos 50 anos. Neste período, as diversas tecnologias construtivas, prediais e de sistemas de operação do edifício também terão sofrido evolução, e o projeto precisa prever um nível de flexibilidade tal que estas mudanças possam ser incorporadas sem grandes impactos.

Portanto, a interação inicial deste tipo de edifício deve incluir também as outras disciplinas de projeto, tais como estruturas e sistemas prediais, em um nível de profundidade que demanda um certo aporte de conhecimentos destas áreas, com o intuito de traduzir melhor os requisitos do empreendimento. 
O atendimento aos diversos requisitos de desempenho que influem na classificação mercadológica do edifício de escritórios, aliado a outros requisitos inerentes aos interesses do empreendedor, tais como flexibilidade de ocupação e significado de expressão na fachada, têm influência direta no volume de investimentos destinados à construção destes empreendimentos e este volume é proporcional ao nível de exigência destes requisitos. Quando Arge (2005) observa que há diferenças significativas do quesito adaptatibilidade nos edifícios de escritórios com a interação direta do usuário final ${ }^{5}$, pode-se inferir que a decisão sobre quanto e como investir no empreendimento está diretamente ligada ao agente que investe. Se o usuário final também é o empreendedor, que é o caso dos edifícios feitos sob medida para sedes de empresas, a abordagem é diferente daquela que se observa entre empreendedores que vendem ou alugam o empreendimento, e que não conhecem este usuário final.

Neste contexto, este trabalho explora os possíveis aspectos de projeto que devem ser considerados já na fase de concepção do projeto para melhorar o desempenho das fases posteriores do processo, incluindo a operação e manutenção do edifício de escritórios como produto imobiliário, cujo usuário final é desconhecido, e que, justamente por este motivo, não tem suas necessidades consideradas.

Estes aspectos envolvem principalmente questões relacionadas à gestão do processo do projeto, principalmente nas etapas iniciais, quando ocorre a concepção artística e comercial do empreendimento, e quando deveria ocorrer o esforço mais pronunciado da questão técnica e do planejamento do processo. Ou seja, procura-se responder às questões sobre quais as interações técnicas mais importantes desta fase do processo devem ser consideradas, e qual a correta seqüência de inserção destas interações pode ser proposta para que o processo do projeto, como um todo, desenvolva-se sem grandes desvios.

\footnotetext{
${ }^{5}$ A pesquisa de Arge (2005) contempla estudos de caso da Noruega, onde os edifícios de escritório de investidores-proprietários apresentam mais atendimentos a quesitos de flexibilidade do que os de investidoresvendedores, e conclui que estes quesitos têm um custo, cujo benefício somente é percebido no uso da edificação ao longo do tempo.
} 


\subsection{OBJETIVOS}

O presente trabalho tem como objetivo principal propor diretrizes para o desenvolvimento e gestão de projetos de edifícios de escritórios. Estas diretrizes consideram os aspectos técnicos multidisciplinares do projeto (arquitetura, engenharia e outras disciplinas) e os aspectos de gestão de seu processo (gestão do processo de projetos), nos quais estão inseridas as questões relacionadas ao uso e manutenção da edificação.

O desenvolvimento desta pesquisa baseia-se na linha de pensamento de que as premissas para desenvolvimento de projetos de edifícios de escritório, cujas decisões técnicas consideram os requisitos de usuários e de administradores prediais (operação e manutenção), podem ser utilizadas para aperfeiçoar as práticas de gestão de projetos de edificações de mesma tipologia que são desenvolvidas exclusivamente para fins de comercialização imobiliária, quando estes dois agentes e seus respectivos requisitos não são conhecidos.

O refinamento deste estudo investiga a possibilidade de se propor uma linha de raciocínio específica para a gestão do processo deste tipo de projeto, por meio de um fluxograma detalhado da fase de concepção, indicando o momento correto de envolvimento e inserção de itens de arquitetura e de outras disciplinas. 


\subsection{METODOLOGIA}

\subsubsection{Considerações metodológicas / estruturação da pesquisa}

O objeto da pesquisa é a gestão das etapas iniciais do processo do projeto de edifícios de escritórios e as informações técnicas multidisciplinares mais relevantes que devem ser consideradas nestas etapas. Com isto, a pesquisa trata de duas vertentes:

- As relações organizacionais envolvidas na gestão de projetos de edifícios de escritórios;

- As principais informações técnicas de cada especialidade de projeto envolvida neste tipo de projeto.

Deste modo, a metodologia da pesquisa foi estruturada de maneira a abordar e caracterizar as duas vertentes acima citadas.

A primeira vertente, relacionada aos aspectos de gestão, é desenvolvida pelo método de estudo de caso, que prevê definição do caso a ser estudado, revisão bibliográfica do tema (com a finalidade de desenvolver questões mais objetivas a serem observadas no caso) e levantamento de dados empíricos (YIN, 2005), com acompanhamento de reuniões de coordenação de projetos e entrevistas com agentes relacionados ao desenvolvimento de edifícios de escritório. O objetivo desta vertente é investigar a possibilidade da proposta de uma seqüência ideal de atividades de gestão no processo para o caso específico de projetos de edifícios de escritório.

A segunda vertente, relacionada a informações técnicas multidisciplinares, baseia-se em revisão bibliográfica acerca de cada tema de projeto, acompanhada de entrevistas com consultores especializados. Estas entrevistas têm a dupla função de confrontar a validade e aplicabilidade das informações da literatura disponível e de observar como cada consultor enxerga sua parte no processo do projeto como um todo, o que complementa, de certa forma, a investigação da primeira vertente.

O trabalho desenvolve-se a partir da soma destas duas vertentes de investigação, que é o desenvolvimento de um fluxo de atividades de gestão, acrescido das informações técnicas que devem ser consideradas em cada atividade no início do processo, aliado, ainda, à fundamentada experiência da pesquisadora como coordenadora de projetos, resultando na proposta das diretrizes de projetos para edifícios de escritório. 


\subsubsection{Montagem e instrumentação da pesquisa}

A seleção da bibliografia para a pesquisa como um todo considerou literatura nacional e estrangeira, sendo a primeira privilegiada especialmente no que se refere a aspectos de gestão, leis, códigos e normas, para contextualizar localmente o trabalho. Produções nacionais e estrangeiras foram igualmente consideradas nos aspectos técnicos, devido a pouca influência do contexto cultural e organizacional sobre os mesmos, e também para fazer o contraponto entre os conceitos quando esta influência se mostra presente.

As pesquisas de seleção de material bibliográfico foram feitas por meio de consulta a bibliotecas (da Escola Politécnica da USP, da Faculdade de Arquitetura e Urbanismo da USP, da Faculdade de Economia e Administração da USP e do Instituto de Pesquisas Tecnológicas), acervo pessoal da pesquisadora, empréstimos de livros e normas por parte de empresas, participação de eventos científicos e não-científicos de assuntos pertinentes à pesquisa, e títulos disponíveis em portais da web, tais como periódicos da Capes $<w w w$.periodicos.capes.gov.br>, e da Science Direct <http://www.sciencedirect.com/>; enciclopédia eletrônica Wikipedia <http://pt.wikipedia.org> e Google books $<$ http://books.google.com.br/ bkshp?hl=pt-BR\&tab=wp>.

Com o intuito de evitar que o aspecto multidisciplinar no contexto técnico da pesquisa desviasse seu foco original, estabeleceu-se o nível de profundidade para desenvolvimento de cada assunto de projeto, com explanação de seus conceitos fundamentais e dos itens mais importantes que devem ser colocados junto com a concepção do projeto de arquitetura, visando o seguinte público-alvo: arquitetos, engenheiros, coordenadores de projetos, empreendedores, administradores prediais e membros de comunidades acadêmicas. O critério para definição destes itens relevantes foi baseado, para cada assunto, na importância que cada disciplina exerce nos estágios iniciais de projeto, nas percepções captadas durante entrevistas com os consultores profissionais e na experiência da pesquisadora na área de coordenação de projetos.

Para a definição do caso a ser estudado, e face à existência de inúmeros agentes envolvidos na gestão do processo de projeto de um edifício de escritórios (empreendedor, construtor, projetistas, consultores, usuários e empresas de administração predial, entre outros), optou-se por acompanhar o agente que mais domínio tem sobre o processo como um todo, que é o empreendedor. Esta opção possibilita a observação da maneira pela qual as interfaces técnicas e comerciais entre agentes são montadas, principalmente as relacionadas com a arquitetura e a coordenação de projetos, e os efeitos oriundos destas montagens. 
Além disso, o empreendedor escolhido para esta pesquisa apresenta uma situação privilegiada em relação ao padrão de atuação do mercado, que é administrar fundos imobiliários por meio de incorporação de patrimônio, e, para tanto, dominar todas as fases do ciclo de vida do edifício: montagem do negócio do empreendimento, gerenciamento de sua construção, execução da operação e manutenção do mesmo por toda a sua vida útil. O padrão de atuação comum do empreendedor no mercado brasileiro para após a etapa da construção do edifício, deixando a problemática da operação e manutenção para os futuros ocupantes. Esta diferenciação de atuação do empreendedor escolhido exerce forte influência nas decisões técnicas de projetos e são estas decisões, favoráveis às questões de consumo de recursos e de sustentabilidade de uma edificação, que a pesquisa deseja captar.

\subsubsection{Planejamento da pesquisa}

Diante do discorrido sobre a metodologia, a pesquisa foi planejada para ser desenvolvida nas seguintes etapas, de forma interativa:

Definição e planejamento

- Seleção e estudo da bibliografia para fundamentar os conceitos teóricos (técnicos e de gestão) e levantamento da linha de pensamento (objetivo).

- Definição do estudo de caso com estabelecimento de critérios sobre os empreendimentos do caso a ser estudado, os dados empíricos a serem coletados e os parâmetros de observação.

\section{Preparação e coleta}

- Acompanhamento do estudo de caso, sem interferência direta ou indireta da pesquisadora no objeto de estudo.

- Realização de pesquisa de campo, por meio de entrevistas com profissionais, para averiguação dos dados técnicos obtidos em revisão bibliográfica.

\section{Análise e conclusão}

- Análise crítica e comparativa dos dados empíricos obtidos com a revisão bibliográfica, com o objetivo de desenvolver e comprovar o objetivo inicial. 
- Redação final da dissertação, apresentando seus resultados, proposições considerações finais.

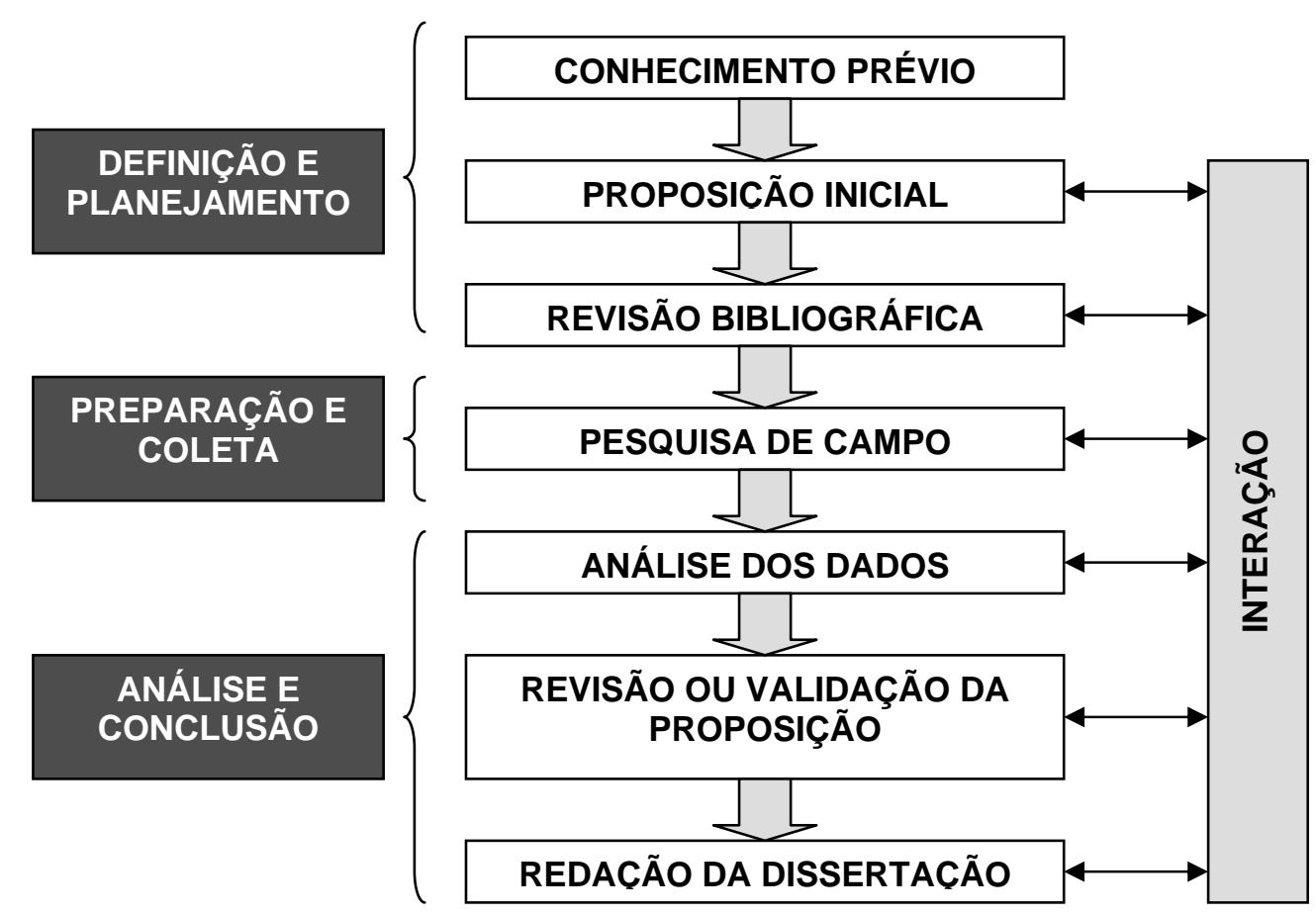

Figura 6 - Etapas da pesquisa 


\subsection{ESTRUTURA DO TRABALHO}

O trabalho é composto por cinco capítulos, A, B, C, D e E, sendo a discriminação de cada capítulo conforme segue:

O capítulo A - Introdução - traz algumas abordagens sobre o tema edifício de escritórios, incluindo os diversos enfoques que podem ser dados para o assunto, e situa o contexto do trabalho, além de apresentar a problemática e a metodologia da pesquisa.

O capítulo B - Especialidades de projeto - apresenta as principais disciplinas técnicas envolvidas em um projeto típico de edifício de escritórios, seus fundamentos teóricos e as informações típicas que devem ser consideradas no início do processo de projeto.

O capítulo C - Gestão de projetos - traz uma revisão bibliográfica que fundamenta e caracteriza os processos de projetos, destacando os diversos arranjos possíveis entre agentes envolvidos e contextualizando estes processos no produto edifício de escritórios.

O capítulo D - Estudo de caso - apresenta e tipifica o estudo de caso, apresentando os dados empíricos, tanto técnicos quanto de gestão, colhidos na pesquisa, além de dados de empreendimentos em diferentes estágios de desenvolvimento. Neste capítulo também é feita uma análise crítica destes dados com as informações contidas nos capítulos B e C, a fim de complementar e aprofundar as investigações já então desenvolvidas. O resultado desta análise consiste na proposição de diretrizes de projeto, da fase de concepção de produto, para o desenvolvimento de edifícios de escritório como empreendimentos imobiliários.

O capítulo E - Considerações finais - traz os resultados da pesquisa com as constatações sobre o tema e o atendimento aos objetivos iniciais, além de reflexões sobre os eventuais benefícios e dificuldades da aplicação prática das diretrizes propostas. Neste capítulo também são identificadas eventuais lacunas e outros itens que poderão se tornar estudos complementares sobre o tema.

A escolha da numeração dos capítulos principais com letras e das seções internas por números foi feita no intuito de evitar excesso de subdivisões nas subseções, notadamente no capítulo B - Especialidades de projeto. 


\section{CAPÍTULO B - ESPECIALIDADES DE PROJETO}

\section{ARQUITETURA}

\subsection{INTRODUÇÃO}

Este capítulo apresenta as considerações arquitetônicas iniciais do projeto de edifício de escritórios. São considerações de caráter restritivo regulamentar ou econômico, sem as quais o projeto do empreendimento pode se tornar inviável. O fracionamento dos assuntos em disciplinas reflete apenas uma maneira metodológica de organizá-los ${ }^{6}$. Todos eles compõem o caráter multidisciplinar da Arquitetura da edificação, que conceitualmente não pode ser fracionada.

Todo projeto inicia-se com a definição do produto e do programa de necessidades, que varia, dependendo do uso final do edifício: uso da própria corporação, venda de unidades, aluguel de unidades, ou investimento de base imobiliária. A correta definição deste programa de necessidades é fundamental para a elaboração de um edifício de escritórios bem sucedido, tanto em termos funcionais, quanto em termos de rentabilidade e satisfação por parte dos usuários. A complexidade na formulação deste programa de necessidades reside na dificuldade de prever a evolução das tecnologias disponíveis (construtivas, organizacionais, de informação), devido ao tempo de antecedência com que estas necessidades devem ser definidas em relação ao início de uso da edificação (entre dois e quatro anos, entre projeto e construção) e ao tempo relativamente longo de sua operação (espera-se entre 30 e 50 anos), intervalos que podem tornar características de funcionamento obsoletas.

Quando o projeto de edifício de escritórios é desenvolvido para o uso de uma corporação específica, o programa de necessidades abrange os objetivos e a forma de organização desta corporação. Quando o projeto é desenvolvido para fins de aluguel ou de investimento e não se sabe as características dos usuários finais, os requisitos relacionados à flexibilidade do uso dos espaços e dos sistemas prediais ganham força.

\footnotetext{
${ }^{6}$ Esta organização fracionada também é adotada pelo mercado para fins de contratação de projetos.
} 


\subsection{PASSOS INICIAIS}

Concluída a etapa de definição do programa de necessidades e tomando por base algumas considerações-chave de Kohn e Katz (2002), pode-se ter a seguinte estruturação para os passos iniciais do projeto de arquitetura:

$\underline{\text { Aspectos delimitados pelo terreno }}$

- Legislação (ocupação, recuos, limitações)

- Cálculo de áreas

- Número mínimo de vagas para veículos

Definição do pavimento tipo

- Configuração de núcleo

- Modulações de projeto

- Altura de piso a piso

As disciplinas complementares, apesar de começarem a ser desenvolvidas após o estudo preliminar da arquitetura, devem ser consideradas ainda nestes passos iniciais, pois nesta fase define-se o potencial comercial do empreendimento e espaços ocupados pelos sistemas estruturais e prediais podem frustrar expectativas, se colocados em etapas posteriores. Na definição do pavimento tipo, as disciplinas complementares que devem ser consideradas nestes passos iniciais são: estrutura, sistemas prediais mecânicos (ar condicionado), sistemas prediais hidráulicos (instalações sanitárias), e sistemas de transporte vertical (elevadores e monta-cargas).

\subsubsection{Aspectos delimitados pelo terreno}

\subsubsection{Legislação}

O primeiro aspecto a considerar, e este aspecto vale também para outras tipologias de projeto, é o terreno ou lote escolhido. Seu formato, tamanho e localização são determinantes para a área máxima construída, a ocupação dentro do lote e o partido 
arquitetônico do edifício. Em muitos países, assim como o Brasil, adotam-se os conceitos de taxa de ocupação (a área máxima em projeção que a edificação pode ocupar no lote) e coeficiente de aproveitamento (número pelo qual se multiplica a área do lote e se obtém a área máxima que pode ser construída). Estes conceitos são relacionados ao plano diretor de cada cidade, têm influência direta no nível de adensamento urbano e podem ser alvo de especulações por parte do mercado imobiliário, pois determinam o potencial construtivo do terreno.

A localização do terreno também determina seus recuos mínimos obrigatórios, o que influi diretamente na aeração e insolação da edificação, e eventualmente na altura máxima da edificação (gabarito de altura). Esta última também pode ser limitada pela largura da via. No município de São Paulo, estas restrições são determinadas pela Lei 13.885/2004 (Lei de Zoneamento), que disciplina o uso e a ocupação do solo.

Uma das maneiras de identificar as restrições legais de um determinado projeto é verificar em quais órgãos governamentais ele deverá passar por aprovação. Há instâncias municipais, estaduais e federais. Em São Paulo, as principais e às que frequentemente são submetidos os projetos de edifícios de escritório são discorridas abaixo:

\section{$\underline{\text { Municipais }}$}

- Sehab (Secretaria da habitação): por meio de seu departamento de aprovação de edificações (Aprov), analisa, entre outras coisas, pedidos de aprovação de construções de edificações de médio a grande porte, de acordo com o Código de Obras do município, Lei de Zoneamento e demais dispositivos legais pertinentes (por exemplo, Código Sanitário, que é estadual).

- Contru (Controle de uso de imóveis): também ligado à Sehab, analisa o sistema de segurança da edificação e fornece licença para instalação de equipamentos de transporte mecânico (elevadores, monta-cargas e escadas rolantes).

- SMT (Secretaria Municipal de Transportes): por meio do CET (Centro de Engenharia de Tráfego), fornece certidão de diretrizes para mitigar situações de polos geradores de tráfego (quando o empreendimento comercial contempla mais de 200 vagas de automóveis ou mais de 80 vagas e está situado em área de tráfego especial).

\section{Estaduais}

- Corpo de Bombeiros do Estado de São Paulo: analisa o sistema de segurança contra incêndio da edificação, baseado no Decreto Estadual no 46.076/01 e respectivas instruções técnicas. Este decreto pode ser considerado como um dos mais rigorosos dentro do território nacional. Muitos empreendimentos ainda adotam, por questões de 
seguro, requisitos norte-americanos da NFPA (National Fire Protection Association). Apesar de muitas instruções do Decreto Estadual terem como base requisitos da NFPA, a conciliação das exigências destes dois órgãos requer uma grande consciência do empreendedor sobre as reais necessidades de atendimento (seja de seguradoras, de certificação ou de aprovação) no projeto, pois os critérios, mesmo quando parecidos, podem ter níveis de exigência diferentes e reflexos diretos nos custos de implantação dos sistemas no empreendimento.

\section{Federais}

- ANAC (Agência Nacional de Aviação Civil): autoriza, por meio da GERs (Gerências Regionais da ANAC) a construção de helipontos privados (muito comuns em edifícios de escritórios sofisticados), de acordo com a Portaria 018/GM5-74 (Instruções para operação de helicópteros e para construção e utilização de helipontos ou heliportos) do Comando da Aeronáutica.

- COMAR (Comando Aéreo Regional): é acionado quando o gabarito máximo de altura, devido ao cone de aproximação de aeroporto, é ultrapassado.

Ainda há, para grandes projetos, a necessidade de se gerar um Relatório de Impacto de Vizinhança (RIV), a ser analisado pelo CADES (Conselho Municipal do Meio Ambiente e Desenvolvimento Sustentável), caso o empreendimento conte com mais de $60.000 \mathrm{~m}^{2} \mathrm{de}$ área computável.

\subsubsection{Cálculo de áreas}

Os critérios para se fazer cálculo de áreas variam de acordo com a finalidade de seus resultados. Para fins legais, a área construída considerada para cálculos de taxa de ocupação e coeficiente de aproveitamento varia de cidade para cidade, de acordo com as regras de zoneamento. Há cidades, como o Rio de Janeiro, onde a taxa e o coeficiente variam de lote para lote. No caso do município de São Paulo, a área que indica o potencial construtivo de um terreno denomina-se área computável, cuja medida considera a face externa da fachada. As considerações sobre o que deve ou não ser contabilizado como computável, ainda neste caso, também variam de acordo com a finalidade do edifício.

Ainda em São Paulo, para o edifício de escritórios, são consideradas não computáveis as áreas de estacionamento de veículos, áticos, térreo em pilotis, apartamento de zelador (até $60 \mathrm{~m}^{2}$ ), terraços que não ultrapassem $10 \%$ da projeção da laje do pavimento, saliências listadas na Tabela 10.12.1 do Código de Obras (como floreiras, pilares, elementos 
arquitetônicos) e equipamentos mecânicos localizados no subsolo ou no ático. Todas as demais áreas cobertas do edifício e não relacionadas acima são consideradas computáveis.

Para estabelecimento de parâmetros para custos de construção da edificação, a área construída total é considerada, genericamente, como toda área edificada coberta (Figura 7). Muitos construtores utilizam a referência da área construída do projeto para aprovação na prefeitura, que é a soma das áreas computáveis com as não computáveis, como área construída total, para compor seus preços. É necessário esclarecer, porém, que os vazios de shafts e caixa de elevadores não são contabilizados como área para aprovação, e, sendo numerosos em edifícios de escritórios de múltiplos pavimentos, podem fazer uma diferença significativa no valor do metro quadrado construído quando contabilizados no levantamento de área construída.

Para o caso de incorporações, existe outro critério para cálculo de áreas e de custos, definidos pela NBR 12721 (ABNT,1999), no qual diversos conceitos de área, tais como privativa, de uso comum, real e global, são explicitados. As áreas consideradas para rateios de custos de condomínios, por exemplo, baseiam-se nos critérios desta norma.

Para fins de comercialização (venda ou locação), os conceitos de área passam a ser o da área útil e o da área de locação, cujos critérios também variam de local para local. Em termos oficiais, consideram-se as mesmas definições da NBR 12721 (ABNT, 1999) para áreas de uso privativo e áreas de uso comum. Pelo fato destas definições serem genéricas, e valerem para qualquer tipo de empreendimento imobiliário (incluindo os edifícios residenciais), muitos empreendedores de edifícios de escritórios e empresas de gerenciamento de patrimônio corporativo adotam um critério norte-americano, a área BOMA (Building Owner and Manager Association), para definição de áreas para locação (Figura 8). Este critério também é regido por norma, a ANSI/ BOMA Z65.1 (ANSI,1996). Nela, estão definidos os conceitos de área útil (usable area), área de locação (rentable area ou leasable area), porção dominante, e grandes penetrações verticais. Estes conceitos de área são utilizados principalmente para determinação e comparação de valores de aluguel, além de análise de eficácia de aproveitamento de área do edifício de escritórios.

Por estes diferentes critérios, um mesmo andar tipo ou até mesmo o edifício como um todo pode ter levantamentos de áreas com resultados totalmente díspares. O correto conhecimento e uso destes conceitos evita a comparação equivocada de valores (custo, venda, aluguel) considerando áreas diferentes. 


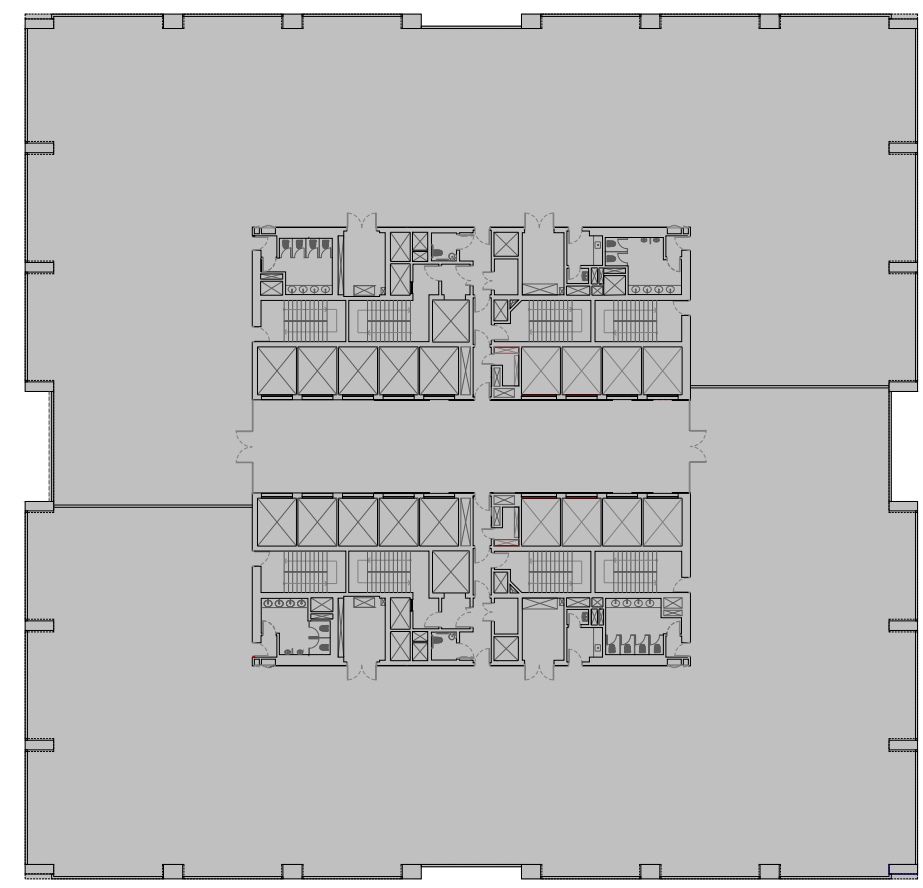

Área construída pelo critério de orçamentação das construtoras.

Equivalente ao termo em inglês gross floor area.

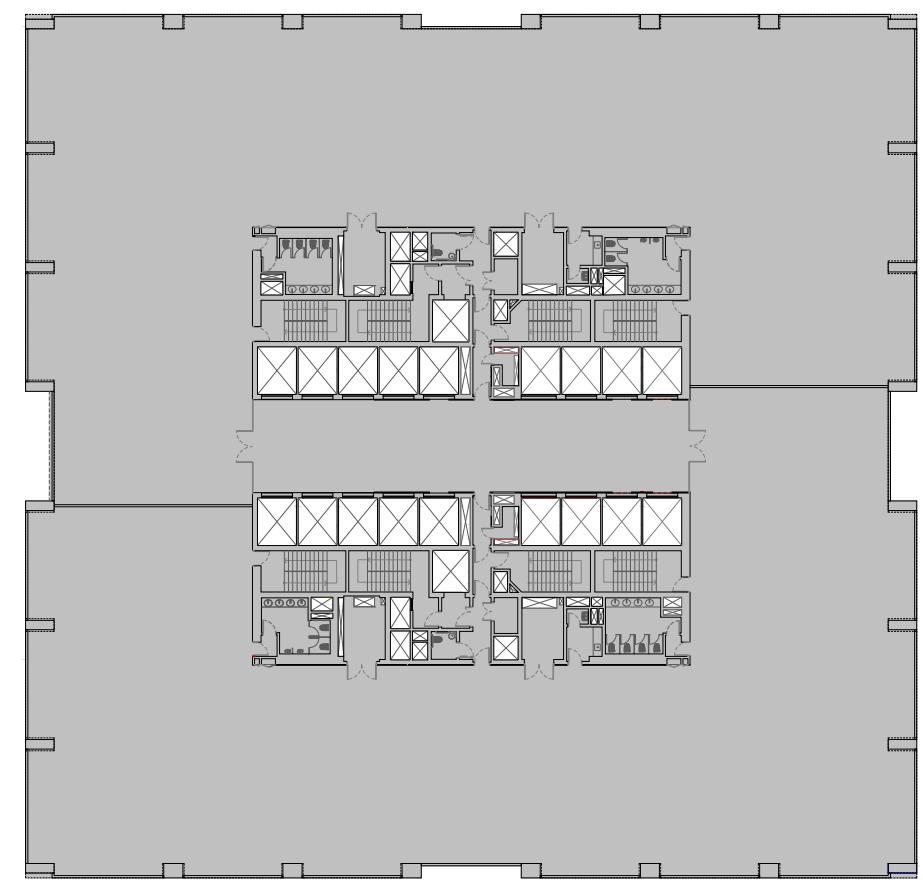

Área construída pelo critério de aprovação na prefeitura do município de São Paulo. No pavimento tipo deste exemplo, ela coincide com a área computável. A diferença de áreas nos dois desenhos é cerca de $6 \%$.

Figura 7 - Ilustração, em planta tipo, dos diferentes critérios de consideração de áreas para cálculo por construtoras e para fins de aprovação legal

Fonte da planta tipo: Orbi (2007) 


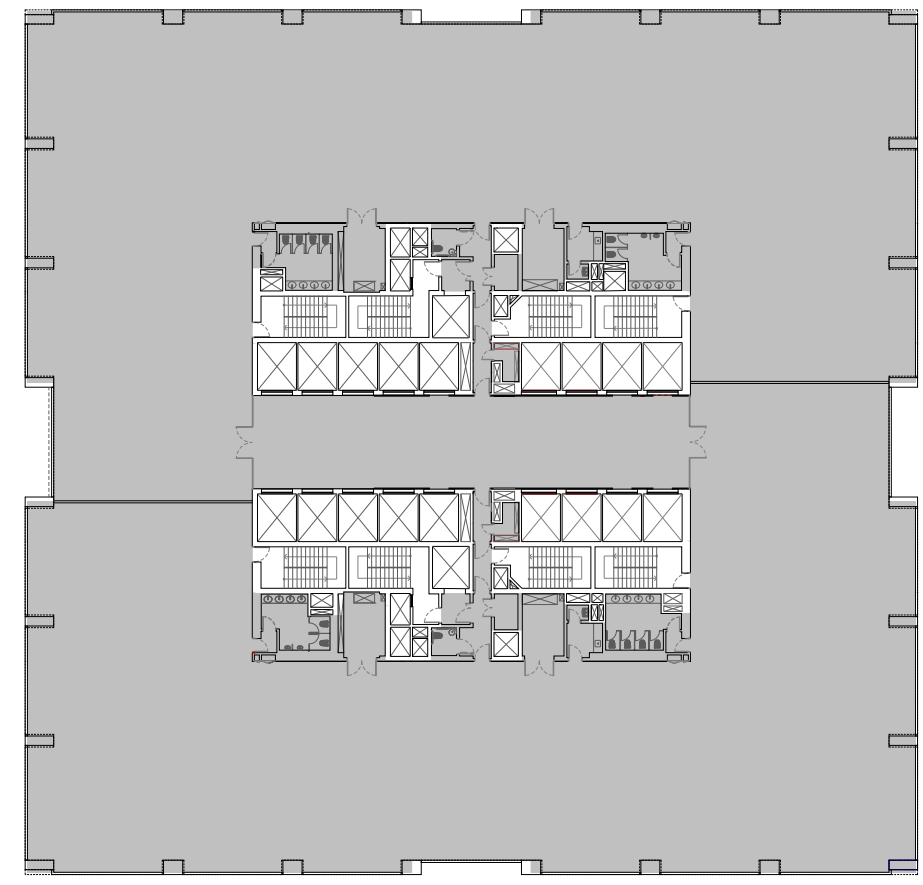

Área construída de locação (rentable area) pelo critério ANSI/BOMA. A diferença de áreas deste critério em relação à área construída considerada pelas construtoras, neste exemplo, é de cerca de $14 \%$.

Figura 8 - Ilustração, em planta tipo, do levantamento de área para locação pelo critério ANSI/ BOMA Fonte da planta tipo: Orbi (2007)

\subsubsection{Vagas para veículos}

Cada cidade tem sua política para circulação de veículos particulares e de transporte coletivo e isto se reflete no cálculo de dimensionamento de vagas de veículos e na necessidade, ou não, de previsão de pátios de carga e descarga. Em São Paulo, este dimensionamento é previsto na Lei de Zoneamento. Como regra geral, pode-se adotar o critério de uma vaga de veículo para cada $35 \mathrm{~m}^{2}$ de área construída computável em edificações de uso comercial, mesmo havendo casos em que o critério considera uma vaga a cada $50 \mathrm{~m}^{2}$. É preferível trabalhar com um pouco de folga nos estudos iniciais, pois estas áreas, caso não sejam utilizadas para estacionamento, podem ser facilmente remanejadas para outros usos. Destas vagas, segundo o Código de Obras de São Paulo, 3\% devem ser reservadas para uso de pessoas com deficiência ou mobilidade reduzida.

$\mathrm{Na}$ ocasião dos estudos para estacionamento de veículos, além de prever vagas para motos (de longa permanência e rotativas), é oportuno admitir a possibilidade de um bicicletário, que tem o duplo benefício de dar opção a uma parcela da população do edifício de utilizar um meio de transporte econômico e saudável, e de permitir a somatória de um ponto no $L E E D^{7}$, caso haja interesse em se fazer uma certificação ambiental do empreendimento. $O$

\footnotetext{
${ }^{7}$ Sigla para Leadership in Energy and Environmental Design. Ver seção 3 do capítulo C.
} 
cuidado que se deve tomar, ao optar pela adoção desta solução, envolve o espaço em si (se esta ocupação não compromete outros usos) e a necessidade de incremento de vestiários e chuveiros para atendimento deste bicicletário.

A importância do dimensionamento do número de vagas do empreendimento, ainda nos estudos iniciais, reflete-se em áreas requisitadas por estas vagas, que determinam a necessidade de eventuais subsolos, e na classificação mercadológica do empreendimento.

\subsubsection{Definição do pavimento tipo}

\subsubsection{Configuração de núcleo do pavimento}

Segundo Kohn e Katz (2002), "o núcleo de um pavimento de escritórios compreende todos os elementos que servem a 'área útil'" (tradução nossa). Estes elementos podem ser entendidos, de modo geral, como as áreas das escadas, elevadores, banheiros, copas e áreas técnicas. Os projetos atuais tendem a agrupar estes elementos, formando os núcleos, de modo que diversas situações favoráveis são criadas, tais como: a utilização das caixas de escadas com paredes estruturais, que também funcionam como proteção passiva contra incêndios; a centralização das prumadas de instalações prediais hidráulicas, que reduzem caminhamentos horizontais de tubulações; e a otimização da distância a percorrer até as escadas de emergência, de modo a atender requisitos de segurança. A localização deste núcleo ou núcleos no pavimento é influenciada por uma série de fatores e caracteriza os edifícios de escritórios basicamente em três tipos, descritos na Tabela 1. 
Tabela 1 - Características das tipologias de núcleo em edifícios de escritórios

\begin{tabular}{|c|c|c|c|}
\hline TIPO & CARACTERÍSTICAS & VANTAGENS & DESVANTAGENS \\
\hline $\begin{array}{l}\text { NÚCLEO } \\
\text { CENTRAL }\end{array}$ & $\begin{array}{l}\text { Tipologia mais } \\
\text { freqüentemente } \\
\text { encontrada em edifícios } \\
\text { de escritório, } \\
\text { principalmente em } \\
\text { arranha-céus. }\end{array}$ & $\begin{array}{l}\text { - Núcleo central estrutural para } \\
\text { resistir ao esforço dos ventos, } \\
\text { abrindo o perímetro para luz e } \\
\text { vista externa; } \\
\text { - Serviços mecânicos localizados } \\
\text { no centro do pavimento; } \\
\text { - Melhor condição construtiva; } \\
\text { - Arranjo flexível para situações } \\
\text { de múltiplos locatários. }\end{array}$ & $\begin{array}{l}\text { - Pouco apropriado } \\
\text { para: pavimentos } \\
\text { pequenos, edifícios } \\
\text { com certas condições } \\
\text { de lote ou edifícios } \\
\text { com funções } \\
\text { especiais, tais como } \\
\text { trading floors }^{8}, \text { que } \\
\text { não são adequados à } \\
\text { configuração de } \\
\text { núcleo central. }\end{array}$ \\
\hline $\begin{array}{l}\text { NÚCLEO } \\
\text { LATERAL }\end{array}$ & $\begin{array}{l}\text { Típico em edifícios com } \\
\text { pavimentos menores ou } \\
\text { com parede divisória na } \\
\text { área de locação. } \\
\text { Também muito utilizado } \\
\text { em locais onde não há } \\
\text { escritórios celulares. } \\
\text { Tem sido padrão } \\
\text { recentemente em países } \\
\text { asiáticos, tais como } \\
\text { Japão e Coréia. }\end{array}$ & $\begin{array}{l}\text { - O núcleo pode se abrir para o } \\
\text { exterior, permitindo ventilação } \\
\text { natural nos espaços comuns; } \\
\text { - O núcleo pode sombrear a área } \\
\text { de escritórios do sol mais forte; } \\
\text { - O sistema de ar condicionado } \\
\text { pode captar com mais facilidade } \\
\text { o ar externo de cada andar; } \\
\text { - A área de locação é homogênea } \\
\text { e pode ser organizada em um } \\
\text { espaço único. }\end{array}$ & $\begin{array}{l}\text { - Uso limitado em } \\
\text { pavimentos com } \\
\text { dimensões muito } \\
\text { grandes, } \\
\text { principalmente devido } \\
\text { às grandes distâncias } \\
\text { a percorrer para } \\
\text { chegar às escadas e } \\
\text { elevadores, o que } \\
\text { contraria normas de } \\
\text { segurança. }\end{array}$ \\
\hline $\begin{array}{l}\text { NÚCLEOS } \\
\text { MÚLTIPLOS }\end{array}$ & $\begin{array}{l}\text { Comum em edifícios } \\
\text { baixos, com pavimentos } \\
\text { de grandes dimensões e } \\
\text { pavimentos estreitos. } \\
\text { Estas configurações } \\
\text { aparecem com } \\
\text { freqüência no norte da } \\
\text { Europa, onde há } \\
\text { escritórios celulares, a } \\
\text { profundidade do edifício } \\
\text { é limitada e os terrenos } \\
\text { são irregulares. }\end{array}$ & $\begin{array}{l}\text { - Distâncias menores a percorrer } \\
\text { até o núcleo; } \\
\text { - O formato do pavimento pode } \\
\text { ser ajustado conforme } \\
\text { condições de terreno e de } \\
\text { contexto; } \\
\text { - Os elementos do edifício podem } \\
\text { ser menores em escala. }\end{array}$ & $\begin{array}{l}\text { - Quantidade total } \\
\text { maior de elevadores; } \\
\text { - Projeto mais } \\
\text { complicado para } \\
\text { lobby e circulação, } \\
\text { requisitando áreas } \\
\text { maiores. }\end{array}$ \\
\hline
\end{tabular}

Baseado em: Kohn e Katz (2002)

\footnotetext{
${ }^{8}$ Pavimentos com características especiais de altura de piso a piso, densidade populacional e requisitos de sistemas de comunicação.
} 


\subsubsection{Modulações de projeto}

Usualmente, utiliza-se uma malha modular para dar suporte ao processo de fazer o desenho propriamente dito da planta do projeto. Para os edifícios de escritórios, Duffy; Cave e Worthington (1980) classificam quatro tipos principais de malha, ou módulos, de acordo com sua função: estruturais, construtivas, de instalações e de arquitetura de interiores. Apesar de serem malhas independentes, é conveniente buscar uma compatibilidade, ou até mesmo uma coincidência entre elas, de forma a permitir configurações de ambientes de trabalho flexíveis e eficientes.

\section{Modulações estruturais}

As modulações estruturais definem as regiões dos elementos principais da edificação, tais como sua estrutura e áreas destinadas aos sistemas prediais, e influem na distribuição dos espaços horizontais e verticais. A definição do módulo estrutural está diretamente relacionada com a profundidade do pavimento e a solução estrutural do edifício.

Kohn e Katz (2002) definem a profundidade do pavimento como "a área útil medida entre a parede externa e o núcleo ou o corredor comum" (tradução nossa), e que apresenta relação direta com interesses do mercado, legislação e cultura local de uso. O acesso à visão das janelas do perímetro, por exemplo, influencia na classificação mercadológica do edifício. Quanto mais profundo é o pavimento, mais flexíveis são as disposições dos espaços e do mobiliário, porém maiores também são as necessidades de iluminação e ventilação artificiais. Duffy; Cave e Worthington (1980) dividem a profundidade do pavimento em quatro tipos: espaço estreito, espaço de profundidade média, espaço profundo e espaço muito profundo (Figura 9), e caracterizam os ambientes de trabalho mais adequados para cada tipo de profundidade de espaço.

Profundidades típicas em países do norte da Europa variam entre 8m, sendo o vão entre o núcleo e a fachada, e $18 \mathrm{~m}$, sendo o vão entre duas fachadas, devido às normas européias de direito à luz natural (KOHN; KATZ, 2002 e ANDRADE, 2007). No Brasil, pela NBR 5413 (ABNT, 1992), há exigência de garantir um nível de iluminância mínimo de 500lux, não necessariamente natural, em área de escritórios e, em São Paulo, o Código de Obras prevê aberturas mínimas de iluminação natural em ambientes de permanência prolongada. Projetos recentes de escritórios de planta livre em São Paulo têm sido concebidos com profundidades próximas a 15m, medida também considerada como ideal por Duffy (1999).

A profundidade do pavimento influencia diretamente na distribuição dos pilares e na solução estrutural do edifício, cujas tipologias são discorridas na seção de Estrutura. De uma maneira simplificada, pode-se dizer que vãos menores entre pilares possibilitam soluções 
mais econômicas do ponto de vista construtivo, mas limitam as opções de arranjos dos ambientes de trabalho; e que vãos maiores são mais desejáveis do ponto de vista de eficiência e flexibilidade de uso do pavimento, porém têm influência direta na equalização da altura de piso a piso e custos de implantação da solução estrutural.

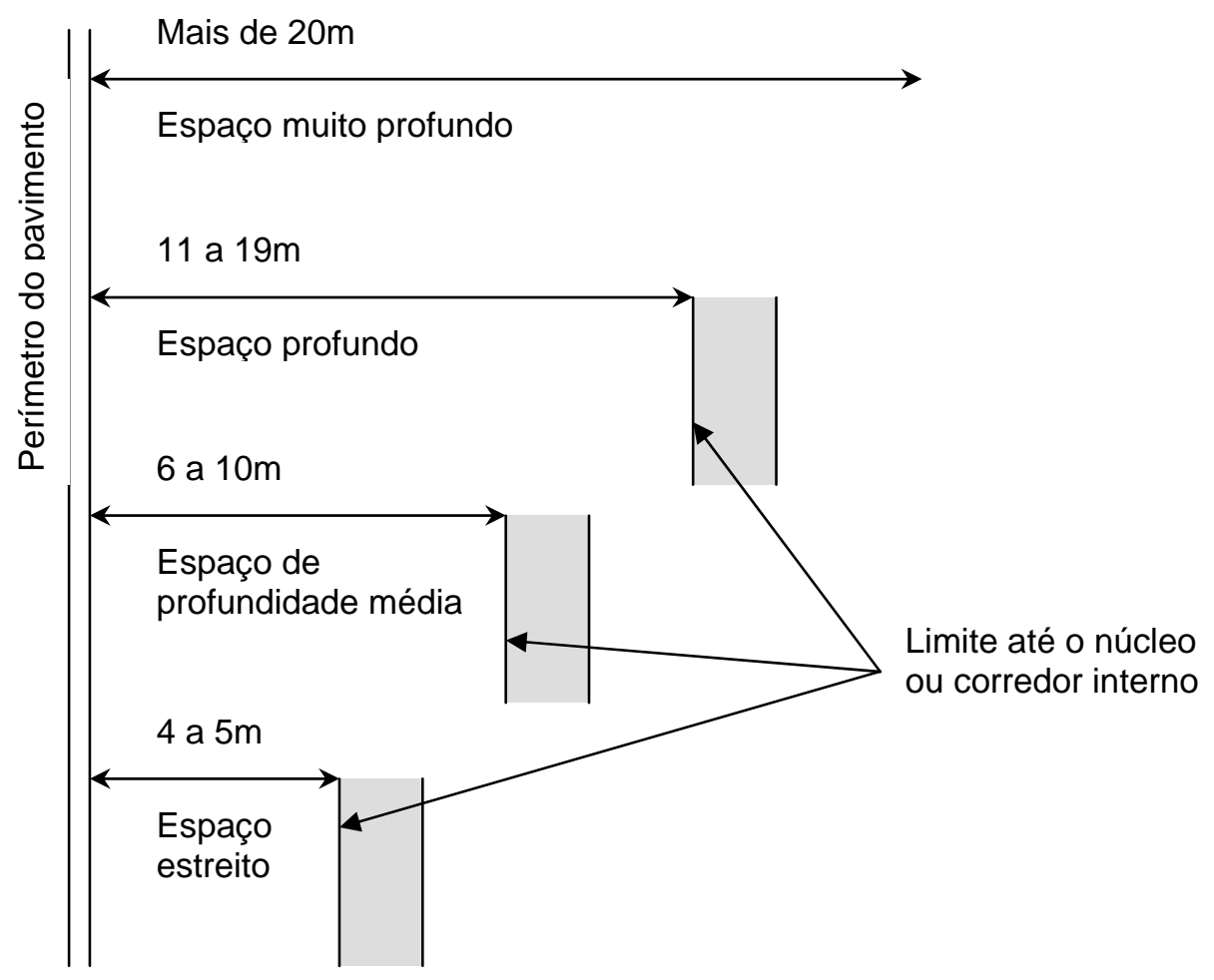

Figura 9 - Quatro profundidades típicas de pavimento

Fonte: Duffy; Cave e Worthington (1980)

Outro aspecto que deve ser lembrado na definição do módulo estrutural, além do equilíbrio com a profundidade ótima do pavimento, é o impacto da "chegada" dos pilares da torre nos andares inferiores (térreos e subsolos). O descompasso entre as modulações adotadas na torre e no embasamento do edifício, ao ser tecnicamente resolvido por meio de estruturas de transição, pode gerar uma interferência indesejável posterior na distribuição das instalações prediais, que encontram, eventualmente, uma barreira nestas estruturas. Vãos típicos entre pilares que possibilitam soluções estruturais relativamente simples são da ordem de 8 a 10m, e estes valores também são interessantes para fins de demarcação de vagas na garagem nos andares inferiores. 


\section{Modulações construtivas}

As modulações construtivas servem para organizar os elementos secundários do edifício, tais como divisórias, forros e caixilhos de fachada. A paginação destes elementos faz parte da expressão da arquitetura, mas alguns itens devem ser considerados. Caso a fachada utilize grandes extensões de vidro, é desejável, em termos construtivos, que o módulo desta tenha uma dimensão tal que se obtenha o aproveitamento máximo no corte da chapa de vidro de origem. Estas dimensões podem ser consultadas junto às empresas que fazem tratamento em vidro (têmpera, deposição de óxidos metálicos, insulamento, etc) ou a consultores específicos. Quanto ao forro, usualmente é utilizado o forro modular com propriedades acústicas e reflexivas (em termos de luz). No Brasil, as modulações de forros com tais propriedades, disponíveis no mercado, são de 0,625m e 1,25m. Freqüentemente esta última dimensão também é adotada como unidade de malha modular para todo o pavimento. Nos EUA, segundo Kohn e Katz (2002), os módulos típicos de malha são de 1,5m; no Japão, 1,6m e 1,8m e na Europa e Ásia, 1,2m e 1,5m.

A definição do módulo desta malha é feita considerando os seguintes aspectos principais: a profundidade do andar, o módulo estrutural, a paginação desejada para a fachada e a paginação para forro da área útil.

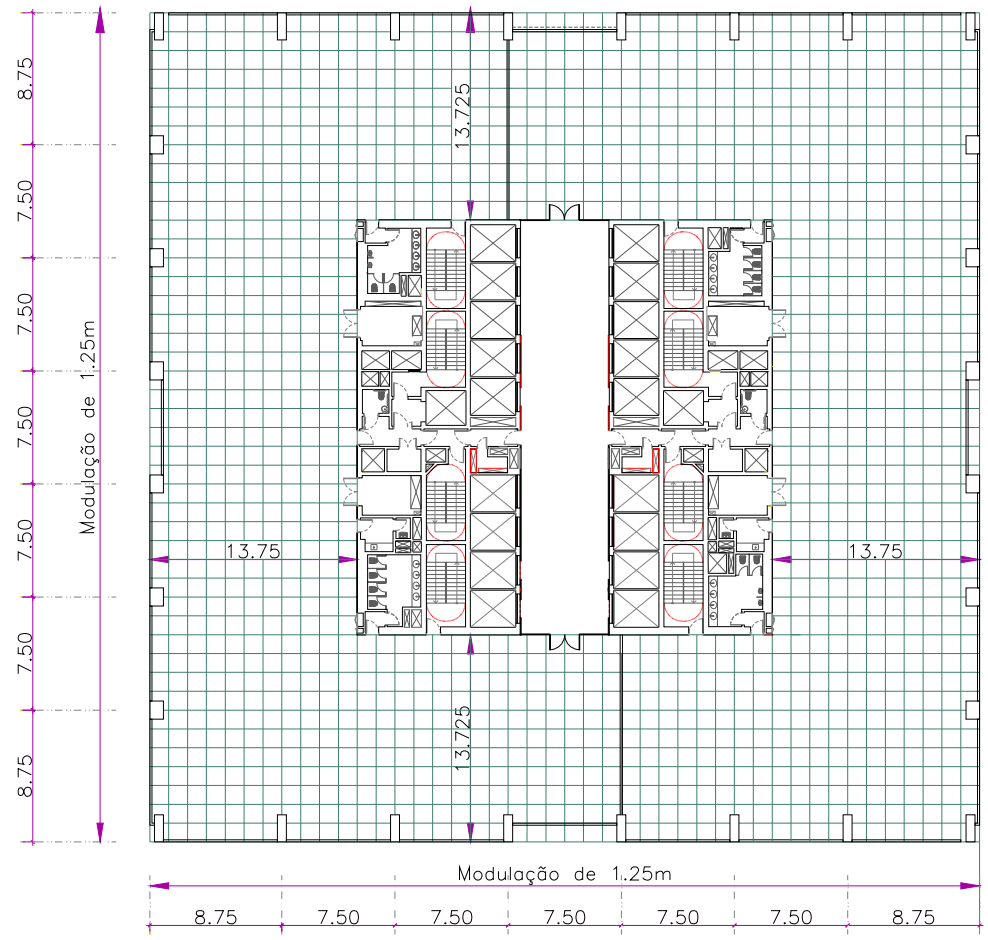

Figura 10 - Planta de pavimento tipo indicando malha modular construtiva e profundidade do andar Fonte da planta tipo: Orbi (2007) 


\section{Modulações de instalações}

As modulações propostas por Duffy; Cave e Worthington (1980) para este item referem-se a projetos onde não há previsão de piso elevado para fazer a distribuição das instalações elétricas, de telefonia e lógica. Em escritórios com salas fechadas, esta distribuição dá-se pelas paredes e pelo rodapé do piso. Em escritórios abertos, deve-se prever uma malha modular para esta distribuição, que pode variar entre 1,20 e 2,50m, sendo que os pontos das instalações são ligados por meio de canaletas embutidas na laje ou por tubos verticais ligados ao forro. Neste tipo de configuração, uma solução do piso elevado simplificaria a questão da distribuição das instalações, além de permitir flexibilidade para disposição interna de mobiliário e pessoas, e para adaptações futuras de sistemas prediais.

\section{Modulações de arquitetura de interiores}

Esta modulação, em escritórios de salas fechadas, determina a distribuição das divisórias e o tamanho das salas. Em escritórios de planta aberta, esta modulação cumpre a função de determinar o tamanho do posto de trabalho padrão e ordenar o conjunto de postos individuais e de equipes. Ela está diretamente relacionada com as dimensões do mobiliário, influencia e é fortemente influenciada pelas outras modulações discorridas anteriormente. Por exemplo, quando se discute a profundidade ideal do andar, está implícita a questão de seu melhor aproveitamento, em termos de ocupação de pessoas. As profundidades medianas permitem arranjos flexíveis em termos distribuição de postos de trabalho e um aproveitamento eficiente do espaço, razão pelo qual são preferidas entre empreendedores e incorporadores que ainda não sabem o perfil do usuário final dos empreendimentos que promovem.

\subsubsection{Alturas de piso a piso}

A altura de piso a piso de um edifício de escritórios que merece uma primeira consideração é a do pavimento tipo, pois a solução que for dada a este pavimento se repetirá por grande parte do corpo do edifício, tendo relevância significativa em sua altura final e na composição da fachada.

Esta altura normalmente é determinada pelas seguintes condicionantes: pé direito interno, espaço para passagem de instalações prediais (seja por forro ou piso) e altura da estrutura (espessura da laje somada à altura da viga, quando houver). Estas condicionantes têm como fatores limitadores principais: a legislação local (quando há, por exemplo, limitação de altura para o edifício) e os custos de construção correlatos (quanto maior a altura de piso a 
piso de uma edificação com múltiplos pavimentos, maiores os custos diretos de construção proporcionais ao número de pavimentos e à respectiva área vertical). A grande dificuldade, na definição desta altura está na conciliação de todos os espaços necessários para o conforto dos ocupantes, com o bom funcionamento dos sistemas prediais e seu fácil acesso à manutenção, dentro de uma somatória mínima possível.

O pé direito interno mínimo é determinado por norma ou legislação local. No município de São Paulo, por exemplo, o Código de Obras prevê um pé direito mínimo de 2,50m para ambientes de permanência de longa duração (considerando nesta classificação as áreas de escritório propriamente ditas) e 2,30m para ambientes de permanência de curta duração (banheiros, copas, áreas técnicas, estacionamento de veículos). Contudo, há empreendedores que consideram uma altura de pé direito maior como agregação de valor percebido ao seu cliente final, considerando alturas da ordem de 2,70m para as áreas de escritório, na intenção de incrementar a classificação mercadológica de seu edifício e obter valores melhores de venda ou aluguel.

A altura mínima entre o forro e a estrutura do pavimento é determinada pela ocupação das instalações prediais. As principais são: dutos do ar condicionado e de exaustão, sistemas de chuveiros automáticos (sprinklers), luminárias, reatores e alimentações elétricas. O próprio forro e seu sistema de fixação não devem ser esquecidos (as chapas têm cerca de $2,5 \mathrm{~cm}$ de espessura), bem como um espaço mínimo para acesso e manutenção das instalações prediais. Quanto maior a profundidade do andar, maiores as dimensões das instalações, pois normalmente as salas técnicas com os equipamentos estão localizadas no seu núcleo. Os equipamentos e dutos do sistema de ar condicionado são os principais responsáveis pela ocupação de altura de forro, e valores entre $0,80 \mathrm{~m}$ e $1,00 \mathrm{~m}$ são bastante comuns para abrigar todos os sistemas mencionados.

Quando há previsão para colocação de piso elevado no andar, deve-se ainda considerar cerca de $15 \mathrm{~cm}$ de altura. Esta altura é suficiente para a passagem e distribuição de cabeamento elétrico, telefônico e de lógica (dados e voz). Para os casos - com uso ainda incipiente no Brasil - de sistemas de distribuição de ar condicionado pelo piso, as necessidades de altura passam a ser maiores, podendo os edifícios de centrais de dados (data centers) serem citados como exemplo (alturas em torno de $1 \mathrm{~m}$ ou mais).

A altura da estrutura, por sua vez, refere-se à espessura de laje somada à altura das vigas (quando houver na área útil), e estas dimensões têm relação direta com a profundidade do pavimento e a solução estrutural adotada ${ }^{9}$. Esta solução, segundo os calculistas estruturais, deve estar estreitamente ligada à concepção do sistema de ar condicionado e à

\footnotetext{
${ }^{9}$ Ver seção 2 deste capítulo.
} 
profundidade do andar, devido ao alto grau de interferência que estes itens exercem sobre a estrutura. Outro aspecto que não deve ser esquecido refere-se à altura de piso a piso nos andares onde ocorrer transição de pilares; ela deve ser maior para comportar a vigas de transição.

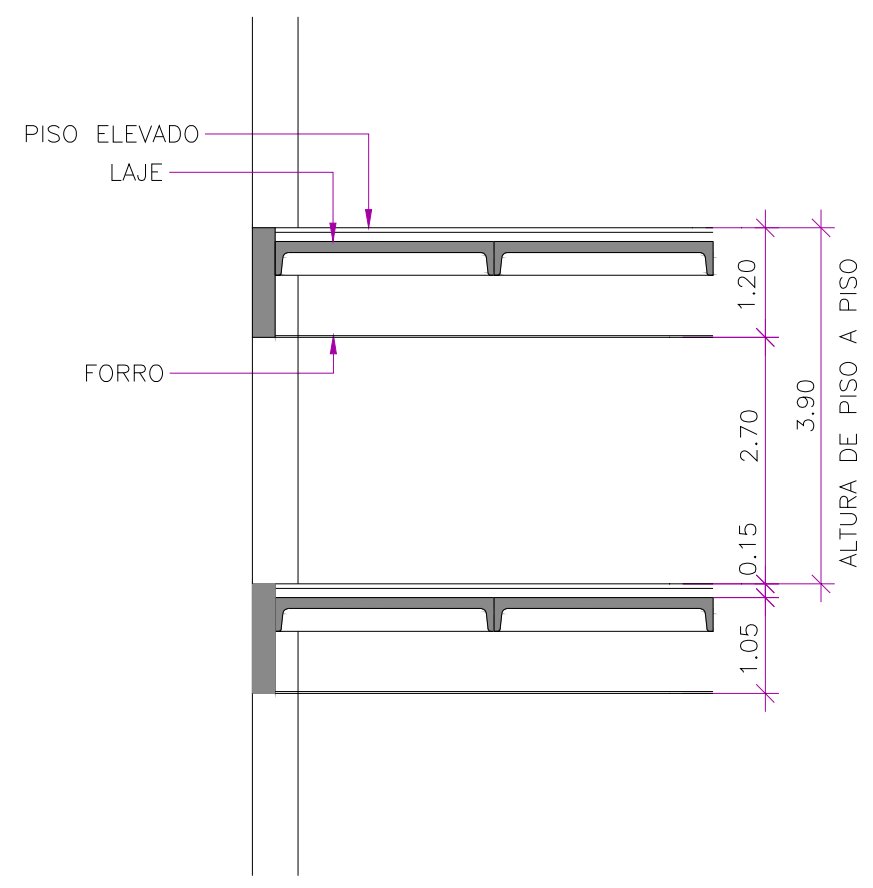

Figura 11 - Corte esquemático de uma periferia de andar tipo indicando medidas das condicionantes típicas para definição de altura de piso a piso entre pavimentos Fonte do corte: Orbi (2008) 


\subsection{FACHADAS}

A definição para o termo fachada como "qualquer das faces de um edifício, de modo geral, a da frente" (FERREIRA, 2009) esconde, com sua simplicidade, um entendimento de que há a percepção do edifício pela sua "face", ou seja, uma construção que "olha" ao seu redor e que é percebida pelo seu entorno (HERZOG; KRIPPNER e LANG, 2008). A fachada também pode ser entendida como algo mais do que uma manifestação bidimensional do limite vertical dos edifícios, abrangendo toda sua espessura e todos os elementos usados para defini-lo em cada caso (MAHFUZ, 2009). O desenvolvimento de tecnologias para o cumprimento das funções primordiais da fachada - proteção, conforto e expressão arquitetônica - acaba por trazer à tona uma especialidade de projeto relativamente nova: o projeto e a consultoria de fachadas. Em projetos de edifícios de escritório, este aspecto é acentuado, de certa forma influenciado, pelos edifícios ícones de cidades como Nova lorque e Chicago, de modo que os materiais mais empregados são aqueles dão a idéia de modernidade e poder econômico, tais como o vidro, as pedras naturais e os metais.

\subsubsection{Caracterização}

As fachadas, do ponto de vista construtivo, podem ser consideradas como a vedação envoltória do edifício, sendo que uma das faces está sempre em contato com o meio ambiente externo ao edifício (SABBATTINI et. al, 2007). Por fazerem parte de um subsistema construtivo da edificação - a vedação vertical -, as fachadas compreendem as paredes, as esquadrias e os revestimentos. Não à toa, o termo utilizado para projeto e consultoria de fachada, traduzido do inglês, é "envelope da edificação" (building envelope). Este termo considera que, além dos limites verticais, o envelope compreende também a cobertura da edificação.

Há diversos critérios para se classificar as fachadas. Segundo Herzog; Krippner e Lang (2008), os dois principais são: critérios funcionais e critérios construtivos.

\section{Critérios funcionais}

Permeabilidade ao ar: estratégias de ventilação natural pedem a permeabilidade do ar variável e controlável. A dissipação de calor em excesso, vapor d’água e, em caso de 
incêndio, gases tóxicos, também requerem certa permeabilidade da fachada. Neste critério, elas podem ser:

- Estanques;

- Abertas;

- Parcialmente permeáveis.

Permeabilidade à luz: a natureza e o nível de permeabilidade à luz controlam o nível de luz natural, criam relações visuais entre o ambiente interno e externo, e governam a quantidade de energia, em forma de calor, que entra e sai do edifício. Neste critério, as fachadas podem ser:

- Opacas;

- Translúcidas;

- Semitransparentes;

- Transparentes;

- Abertas.

Ganhos de energia: superfícies permeáveis à radiação solar permitem ganhos diretos de energia, que podem ser aproveitados ou não pela edificação (ex: utilização de painéis fotovoltáicos na fachada para geração de energia elétrica). Neste critério, os ganhos de energia podem ser:

- Nenhum;

- Em forma de calor;

- Em forma de eletricidade.

Variabilidade: a superfície de uma fachada pode reagir à mudança das condições externas, mudando a posição ou propriedade dos seus componentes. Esta mudança pode ser:

- Nenhuma;

- Mecânica: por partes móveis da fachada (ex: brises ou sombreamentos ajustáveis);

- Física: por iniciação de processos reversíveis de mudança de propriedade físicas dos materiais, utilizando processos elétricos, termossensíveis ou fotossensíveis;

- Química: por mudança de propriedades químicas dos materiais, pelos mesmos processos citados para as mudanças físicas.

Controle: a variabilidade requer controle, que pode ser feito de maneira: 
- Manual ou mecânica;

- Automática (sem necessidade de intervenção humana ou de processadores);

- Com circuitos de controle (ex: ligados a algum sistema de automação).

Critérios construtivos

Função estrutural: as fachadas, como vedações externas, podem auxiliar a transmissão de cargas e a rigidez da estrutura. Neste critério, elas podem ser:

- Com função estrutural;

- Sem função estrutural.

Construção em camadas: camadas de diferentes materiais podem compor uma fachada, assim, elas podem ser:

- Com camada única;

- Com múltiplas camadas.

Ventilação: a ventilação da própria fachada implica em camadas múltiplas, sendo uma delas de ar, que permitem a dissipação do calor e da condensação pelo efeito chaminé. Neste critério, as fachadas podem ser:

- Com camada de ar ventilada;

- Com camada de ar estanque.

Pré-fabricação: o nível de pré-fabricação desejado tem efeitos na concepção do projeto, na natureza dos elementos, no tamanho real de cada componente e nas condições governantes de montagem da fachada. Por isto, neste critério, as fachadas podem ter:

- Baixo nível de pré-fabricação;

- $\quad$ Alto nível de pré-fabricação.

Outra forma possível de classificar as fachadas é considerando o ponto de vista da técnica construtiva. As fachadas, como vedações verticais externas (SABBATTINI et. al, 2007), podem ser:

Por conformação: vedações obtidas por moldagem a úmido no local, com emprego de materiais com plasticidade obtida com a adição de água. Ex: paredes de alvenaria de blocos assentados com argamassa.

Por acoplamento a seco: vedações obtidas por montagem através de dispositivos de fixação (pregos, parafusos, rebites, etc.). Ex: parede de gesso acartonado. 
Ainda sob este ponto de vista, as fachadas podem ser classificadas em função do momento em que o acabamento é incorporado a elas (OLIVEIRA, L., 2009):

Com revestimento incorporado: vedações verticais que são posicionadas acabadas em seus lugares definitivos, sem a necessidade de aplicação de revestimentos a posteriori. Ex: painéis pré-fabricados arquitetônicos de concreto.

Com revestimento a posteriori: vedações verticais que são executadas em seus lugares definitivos, sem a aplicação prévia de revestimentos. Ex: alvenarias que recebem revestimentos aderidos ou não-aderidos.

Sem revestimento: vedações verticais que não necessitam da aplicação de revestimentos. Podem ser aparentes ou receberem unicamente uma pintura. Ex: fachadas envidraçadas.

Sob a ótica construtiva, uma forma possível de organizar as tipologias de vedações verticais, e conseqüentemente de fachadas, é pela combinação das duas classificações acima comentadas (Figura 12).

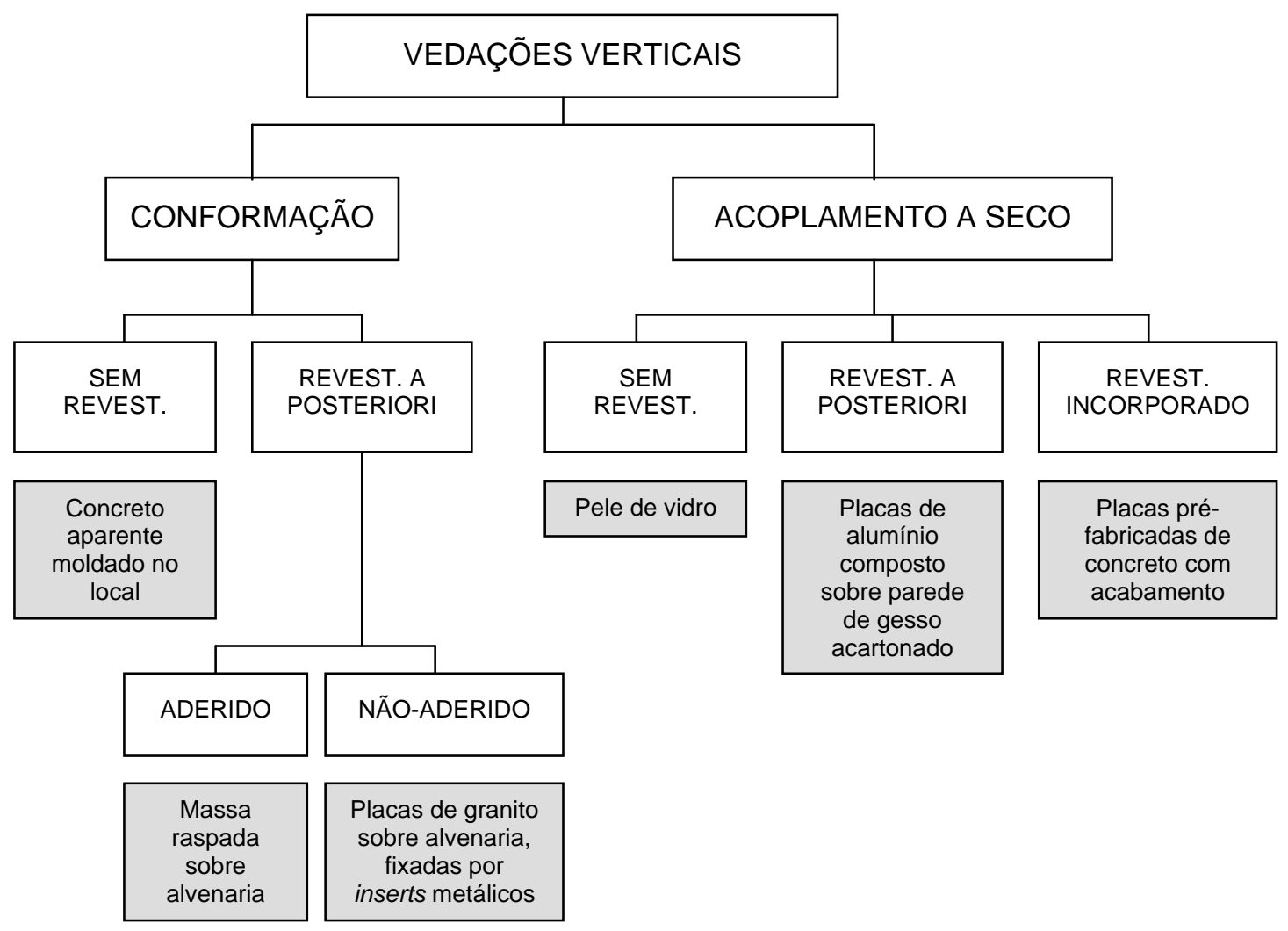

Figura 12 - Tipologias de vedações verticais, sob o ponto de vista construtivo, e alguns exemplos (em cinza) 
Outra classificação possível é relacionada à densidade superficial da fachada como vedação vertical, podendo ser (OLIVEIRA, L., 2009):

Leve: vedação vertical não estrutural, constituída de elementos de densidade superficial baixa, cujo limite aproximado é $100 \mathrm{kgf} / \mathrm{m}^{2}$;

Pesada: vedação vertical que pode ser estrutural ou não, constituída de elementos de densidade superficial superior ao limite pré-determinado de aproximadamente $100 \mathrm{kgf} / \mathrm{m}^{2}$.

As fachadas leves podem, ainda, ser classificadas de acordo com seu posicionamento em relação à estrutura principal do edifício (norma francesa AFNOR NF P 28 001, 1990 apud OLIVEIRA, L., 2009):

Fachada-cortina: fachada leve, constituída de uma ou mais camadas, posicionada totalmente externa à estrutura do edifício (à face exterior das lajes de borda) formando uma pele sobre o mesmo. Em inglês esta classificação é conhecida pela expressão curtain wall.

Fachada semi-cortina: fachada leve, constituída de uma ou mais camadas, cuja camada exterior é posicionada externa à estrutura do edifício e a camada interior interna e entre pavimentos. Esta norma considera que a camada interior não obrigatoriamente deve ser leve, existindo casos em que a camada interior da fachada semi-cortina é uma parede em alvenaria ou em concreto e a camada exterior um revestimento não-aderido.

Muitos projetos recentes de edifícios de escritórios têm utilizado as fachadas-cortina, cuja definição brasileira está na norma de caixilhos (esquadrias) especiais NBR 10821 (ABNT, 2000) como:

Caixilhos interligados e estruturados com função de vedação que formam um sistema contínuo, desenvolvendo-se no sentido da altura e/ou da largura na fachada da edificação, sem interrupção pelo menos por dois pavimentos.

Isto decorre da influência da abertura de mercado e o ingresso de projetos de origem norteamericana, que tratam das fachadas de edifícios de escritórios genericamente como curtain walls (KHOURY, 2002), sem sequer considerar as outras formas possíveis de se projetar o envelopamento deste tipo de edifício.

A fachada-cortina pode ser composta por uma envoltória por acoplamento a seco sem revestimento, como é o caso das fachadas envidraçadas do tipo "pele de vidro", e, a semicortina, por uma vedação por conformação com revestimento não-aderido, como é o caso das placas de alumínio composto sobrepostas a paredes de alvenaria por meio de estrutura auxiliar (Figura 13). 
a)

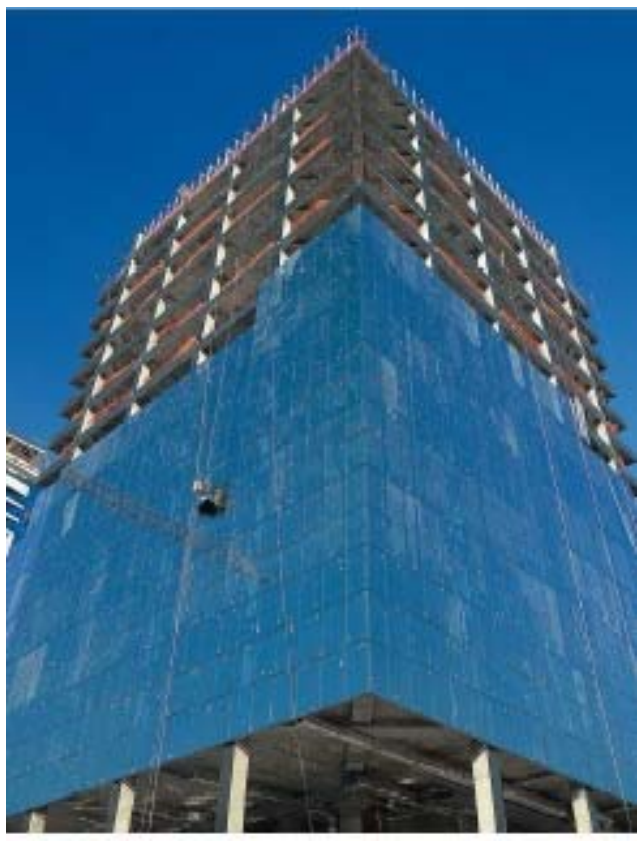

b)

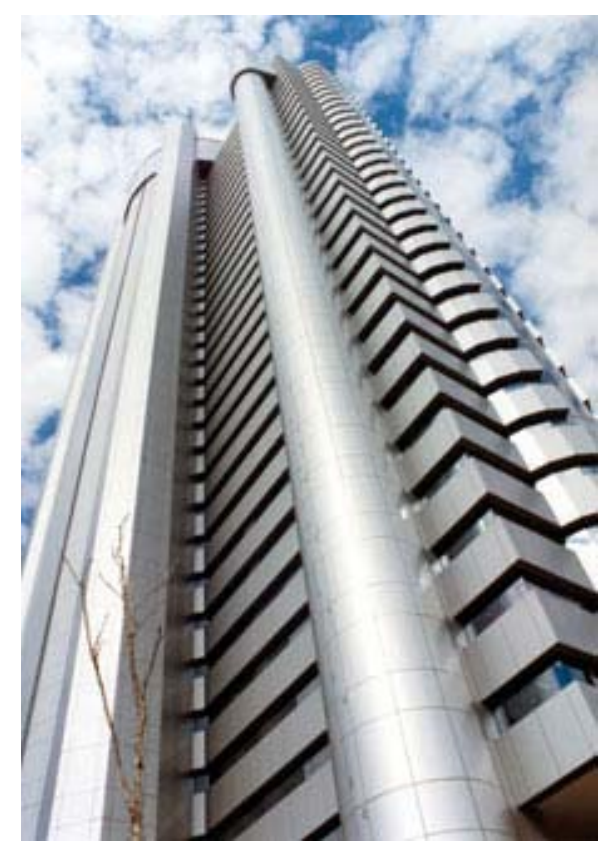

Figura 13 - Exemplos de edificações com fachadas leves, sendo: a) fachada-cortina e b) fachada semi-cortina Fonte: a) Duarte (2009) e b) Bratke (2009)

Efeitos interessantes em edifícios de escritórios também podem ser obtidos com fachada pesada, construída por acoplamento a seco e revestimento incorporado (Figura 14).

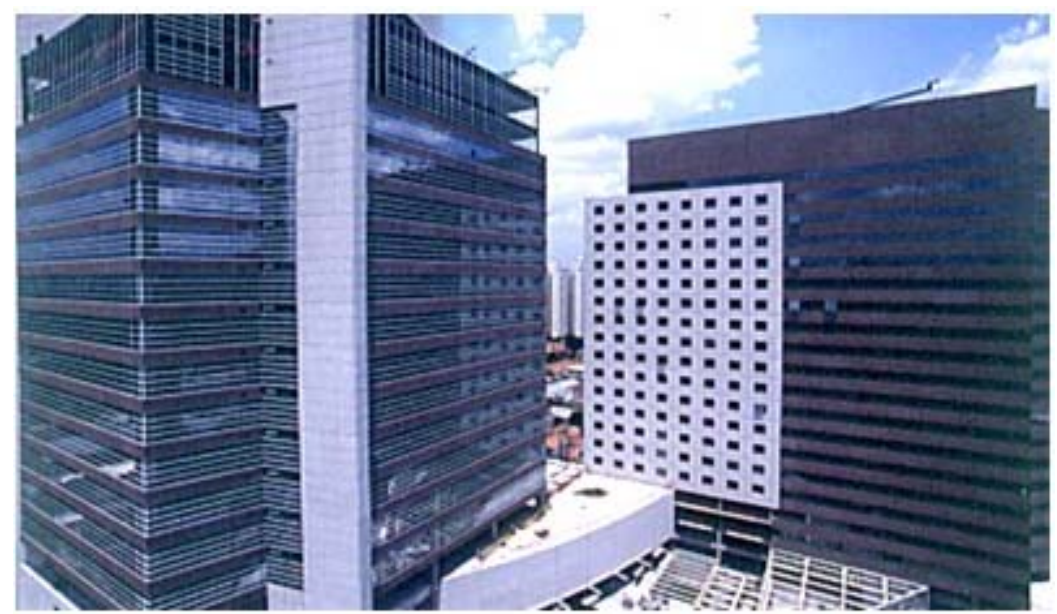

Figura 14 - Exemplos de edifício de escritórios com fachada em placas pré-fabricadas de concreto com granito incorporado

Fonte: http://www.continentalsquare.com.br/indexh.htm 
As fachadas-cortina e semi-cortina com múltiplas camadas podem ainda ser compostas de maneira que exista uma camada de ar, que pode ser estanque ou não. Neste caso, elas são consideradas fachadas duplas e, quando o ar do espaço pode circular para o ambiente externo, elas são consideradas fachadas ventiladas (Figura 15).

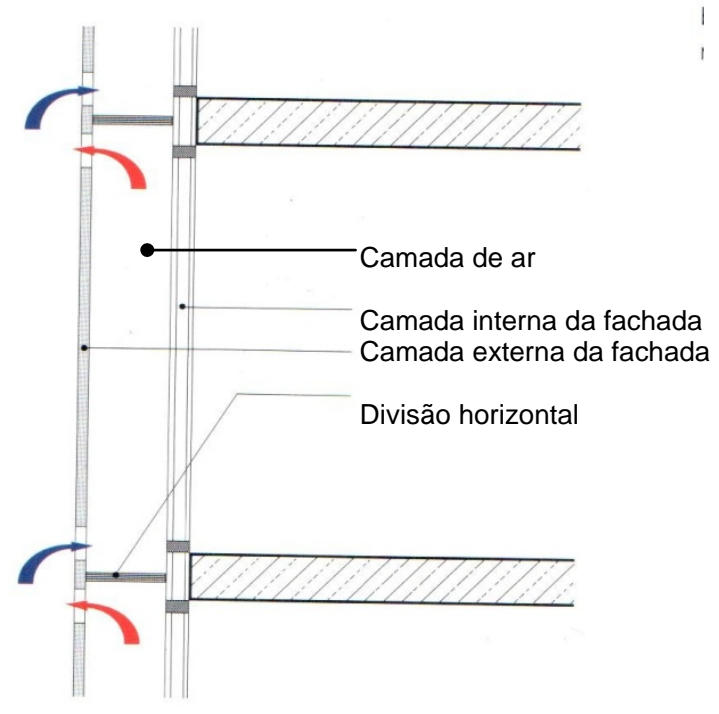

Figura 15 - Corte esquemático de uma fachada dupla ventilada Fonte: Oesterle et. al (2001)

Os materiais de acabamento mais utilizados em projetos que têm fachadas-cortina e fachadas semi-cortina são: vidro, pedra natural e chapas metálicas (alumínio composto e aço inoxidável, os mais utilizados). Na Europa, em especial na França, as chapas cimentícias também são utilizadas com freqüência. Herzog; Krippner e Lang (2008), em seus estudos sobre fachadas no geral, também consideram como materiais de destaque a cerâmica, o concreto, a madeira e as resinas plásticas. 

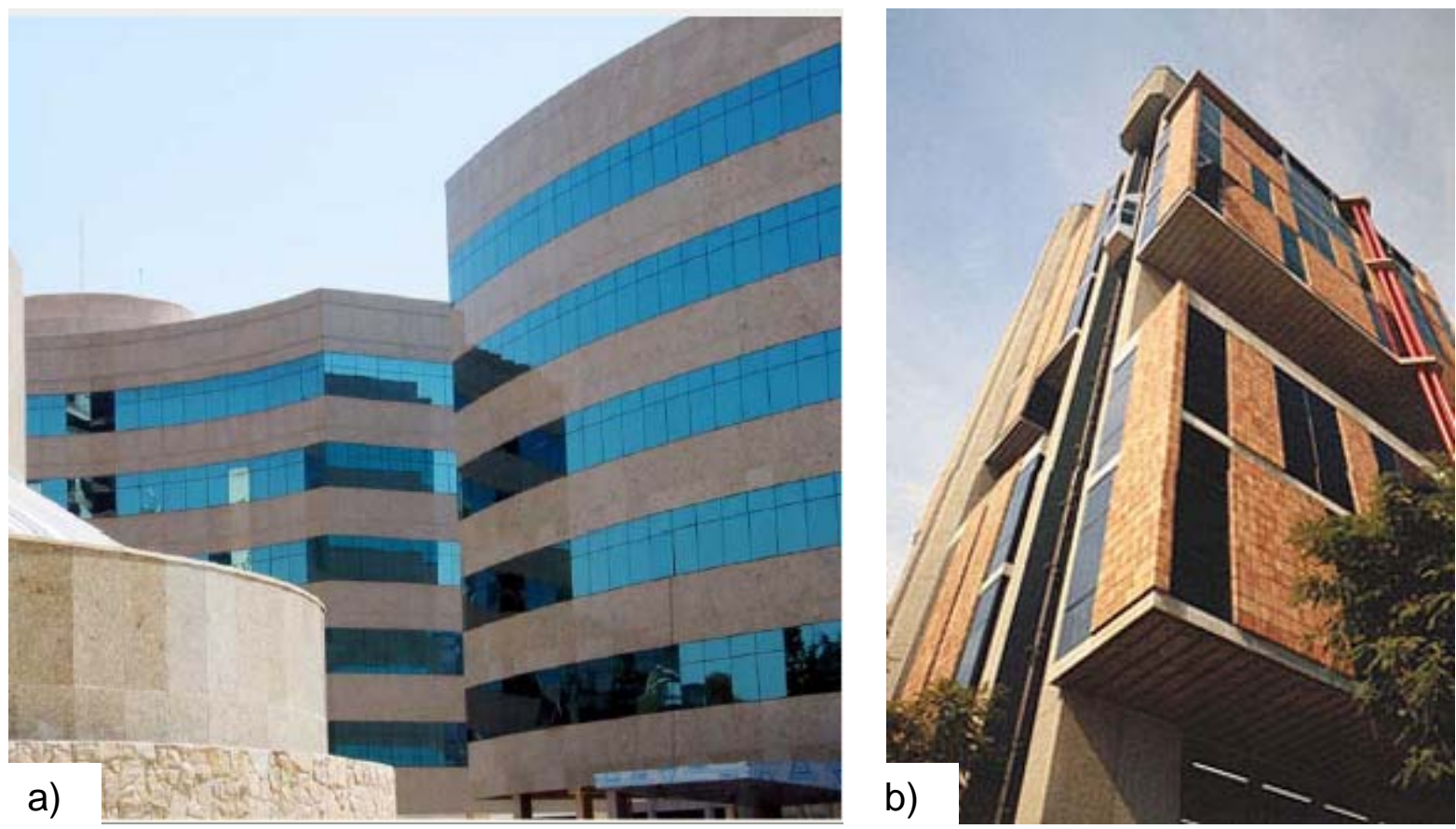

Figura 16 - Exemplos de fachadas de edifícios de escritórios

sendo: a) fachada por conformação e revestimento não-aderido de granito e b) fachada por conformação e revestimento aderido de cerâmica

Fonte: a) Botti e Rubin (2009) e b) Bratke (2009)

\subsubsection{Funções e desempenho}

As funções primordiais das fachadas na edificação referem-se à proteção do ambiente interno em relação às condições externas, que podem ser permanentes ou variáveis, criando condições mínimas de flutuação interna e propiciando conforto aos usuários. O componente expressivo também está presente, pois a fachada não pode estar dissociada do restante da edificação, e a evolução da arquitetura, das técnicas construtivas e o incremento da diversidade de materiais disponíveis acentuam este aspecto, tornando-o também uma função primária da fachada.

Sob o ponto de vista técnico, as fachadas podem exercer outras funções, consideradas como as funções secundárias das vedações (LORDSLEEM JR., 1998):

- Suporte e proteção às instalações;

- Proteção aos equipamentos do edifício;

- Criação de condições de habitabilidade; 
- Atuação estrutural plena ou parcial.

Uma forma objetiva de avaliar a adequação destas atribuições da fachada no funcionamento da edificação aparece na recente norma brasileira de desempenho, NBR 15575-4 (ABNT, 2008). Apesar desta norma ser direcionada para edifícios habitacionais de até cinco pavimentos e ter parâmetros mínimos de desempenho pouquíssimo rigorosos, ela tem por mérito: a) tratar do conceito de vida útil dos sistemas da edificação e das responsabilidades inerentes do projeto, e b) tratar do conceito do desempenho que determinado sistema ou subsistema construtivo deve apresentar, ao invés de determinar a forma dele ser construído. Estas tratativas possibilitam que aspectos relacionados à vida útil, desempenho e renovação das fachadas sejam equacionados com a escolha do partido arquitetônico e do sistema construtivo. Os requisitos de desempenho para as fachadas - como vedações externas discorridos nesta norma são indicados na Tabela 2.

Tabela 2 - Requisitos de desempenho para vedações, e que podem ser aplicados a fachadas

\begin{tabular}{|c|c|}
\hline \multicolumn{2}{|r|}{ Segurança estrutural } \\
\hline- & Estabilidade e resistência estrutural \\
\hline- & Limites para deslocamentos, fissuração e descolamentos \\
\hline- & Resistência à solicitação de cargas suspensas e a impactos \\
\hline \multicolumn{2}{|r|}{ Segurança contra fogo } \\
\hline- & Dificultar a ocorrência da ignição do fogo e de sua propagação \\
\hline \multicolumn{2}{|r|}{ Uso e operação } \\
\hline \multicolumn{2}{|r|}{ - $\quad$ Atender às condições de uso e operação } \\
\hline \multicolumn{2}{|r|}{ Estanqueidade } \\
\hline- & Ser estanque à água proveniente de chuvas e de outras fontes \\
\hline \multicolumn{2}{|r|}{ Conforto térmico } \\
\hline- & Propiciar condições de conforto térmico compatíveis com as condições bioclimáticas locais \\
\hline \multicolumn{2}{|r|}{ Conforto acústico } \\
\hline & $\begin{array}{l}\text { Propiciar condições de conforto acústico compatíveis com o nível de ruído de fundo do local da } \\
\text { edificação, em termos de transmissão aérea e estrutural e em termos de privacidade acústica }\end{array}$ \\
\hline \multicolumn{2}{|r|}{ Durabilidade e manutenibilidade } \\
\hline & $\begin{array}{l}\text { Manter a capacidade funcional e características estéticas compatíveis com o envelhecimento da } \\
\text { vida útil dos materiais, submetidos a intervenções periódicas de conservação }\end{array}$ \\
\hline
\end{tabular}

Baseado em: NBR 15575-4 (ABNT, 2008)

Além dos requisitos previstos em norma, podem também ser mencionados como requisitos importantes de desempenho: os de Conforto Lumínico (uso de luz natural, sistemas de sombreamento e antiofuscamento) e de Estanqueidade ao Ar (controle de fluxo de entrada 
do ar). Todos eles influenciam diretamente o projeto dos sistemas construtivos da fachada, de seus materiais, e desta como um todo. Não à toa, os assuntos relacionados às condições de habitabilidade abordados pela norma de desempenho são muito parecidos com os requisitos de qualidade ambiental interna, tratados pelas entidades certificadoras de selos verdes para edifícios ${ }^{10}$.

\subsubsection{Importância das fachadas no conforto e sustentabilidade do edifício}

O conforto interno de uma edificação é o resultado de múltiplas variáveis, entre elas as externas (localização, condições climáticas), as internas (projeto, forma, sistema construtivo, sistemas prediais, materiais) e as do usuário (diferentes pessoas e culturas têm diferentes padrões de conforto). Neste contexto, a fachada da edificação tem uma importância bastante significativa no resultado do conforto interno, por ela ser o meio que separa as condições externas das internas. Como as condições internas são as percebidas pelos usuários da edificação, é necessário pensar quais os parâmetros destas condições que se deseja obter, antes de procurar por soluções puramente técnicas para o projeto da edificação e das fachadas.

Alguns parâmetros destas condições podem ser extraídos dos níveis "I" (intermediário) e "S" (superior) da norma de desempenho NBR 15575-1 (ABNT, 2008); de outras normas, como os padrões da $A S H R A E^{11}$ para o conforto térmico; e dos quesitos para obtenção de certificação de sustentabilidade, tendo como exemplo os requisitos do LEED. Considerando as principais categorias de conforto, como: conforto térmico e de qualidade do ar; conforto lumínico; conforto acústico e conforto antropodinâmico (referente à ergonomia e acessibilidade), pode-se dizer que, em edifícios de escritórios, as duas últimas categorias podem ser resolvidas, na maior parte das vezes, com sistemas passivos (que não consomem energia), enquanto que as duas primeiras, com grande enfoque no conforto térmico, necessitam de sistemas prediais ativos que consomem uma parcela substancial de energia na operação do edifício.

A influência da fachada no conforto acústico em edifícios de escritórios refere-se ao isolamento do ambiente interno de ruídos aéreos e de ruídos de impacto na cobertura, e manutenção de ruído de fundo compatível com as atividades dos usuários. Este isolamento deve ser obtido de forma que a composição dos materiais da fachada considere:

\footnotetext{
${ }^{10}$ Ver seção 3.2 do capítulo C.

${ }^{11}$ Sigla para American Society of Heating, Refrigerating, and Air-Conditioning Engineers.
} 
componentes densos (massa) e componentes fono-absorventes (mola), além de mecanismos para evitar frestas não-desejáveis no conjunto, já que o som é uma onda mecânica de diferentes freqüências que se propaga pelo $\operatorname{ar}^{12}$.

Já o consumo de energia para a geração de conforto está diretamente relacionado à questão da sustentabilidade do edifício em sua operação. De um modo geral, quanto menos energia o edifício consome para sua operação, mais sustentável ele é do ponto de vista de economia de recursos e de menor geração de dióxido de carbono (o principal agente gerador do efeito estufa). Yeang (2006) propõe cinco modos básicos de sistemas para criação de condições de conforto em edificações, relacionados ao uso de energias nãorenováveis:

- Sistemas de modo passivo: sistemas que não utilizam energias não-renováveis e que devem preferencialmente ser considerados na concepção de projetos ecológicos;

- Sistemas de modo misto: sistemas parcialmente assistidos por equipamentos eletromecânicos (ex: ar condicionado) com o objetivo de otimizar outras energias ambientes do local;

- Sistemas de modo completo: sistemas totalmente assistidos por equipamentos eletromecânicos;

- Sistemas de modo produtivo: sistemas que geram energia na própria edificação (ex: geração fotovoltáica e eólica);

- Sistemas de modo composto: sistemas que formam uma composição de todos os mencionados acima.

Sob o raciocínio de Yeang (2006), o sistema de modo passivo é o que primeiramente deve ser considerado, pois supõe que o consumo energético da edificação será otimizado e que ela funcionará relativamente bem, mesmo com uma falha no fornecimento de energia. Os principais métodos passivos propostos por ele, que podem ser obtidos pelos modos passivo e misto, no projeto de uma edificação são:

- Configuração da forma do edifício e implantação no terreno;

- Orientação da edificação (fachadas e aberturas principais);

- Projeto da fachada, incluindo dimensões das aberturas, localização e detalhamento;

12 O som é uma vibração em um meio elástico, que pode ser ar, água, materiais de construção e solo. Esta vibração é uma onda, cuja frequência é medida em Hertz $(\mathrm{Hz})$, e as frequências audíveis ao ouvido humano situam-se entre 20 e $20.000 \mathrm{~Hz}$ (EGAN, 1988). As frequências mais baixas são isoláveis por materiais densos, com mais massa molecular (efeito "massa"), e as frequências mais altas podem ser combatidas com materiais mais leves, porém com propriedades físicas que amortecem a vibração ao seu contato, gerando o efeito "mola". 
- Mecanismos de controle solar (ex: sombreamento de fachadas e janelas);

- Conceitos de uso passivo da luz natural (uso de condutores de luz);

- Ventos e ventilação natural;

- Cobertura da edificação;

- Cor da envoltória da edificação;

- Paisagismo (uso da vegetação ao longo da edificação, não só no térreo);

- Sistemas de refrigeração passivos;

- Inércia da edificação (de acordo com os materiais construtivos e sua composição na edificação).

Como alguns exemplos de aplicações dos métodos passivos, podemos mencionar: a forma da edificação (e, consequentemente, da envoltória) mais adequada ao clima (Figura 17); a orientação solar; a utilização de dispositivos externos de sombreamento (brises); a utilização de meios passivos de refrigeração do edifício, como a ventilação natural noturna ou a fachada ventilada; a escolha dos materiais de composição e acabamento; a adequação da área envidraçada e do tipo de vidro ao clima; e dispositivos ajustáveis para controlar a permeabilidade da fachada (luz, ofuscamento, ventilação natural) de acordo com as condições climáticas externas.

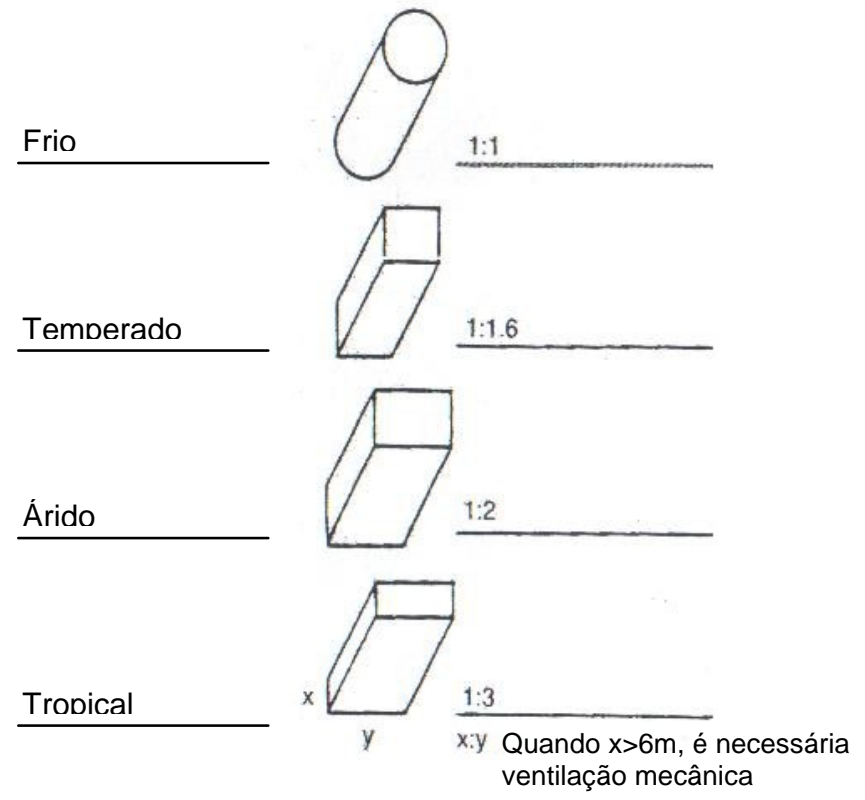

Figura 17 - Proporções consideradas ótimas de edificações de acordo com o clima Fonte: Yeang (2006) 
Os modos passivos e mistos também apresentam, de um modo geral, alternativas de soluções de baixo impacto nos custos de construção, se comparados com os modos ativos e produtivos. No estudo de alternativas para as fachadas do prédio da prefeitura (City Hall) de Londres, Hall; Shuttleworth e Hyams (2003) esquematizaram a relação entre as soluções destes modos e os custos implicados (Figura 18).

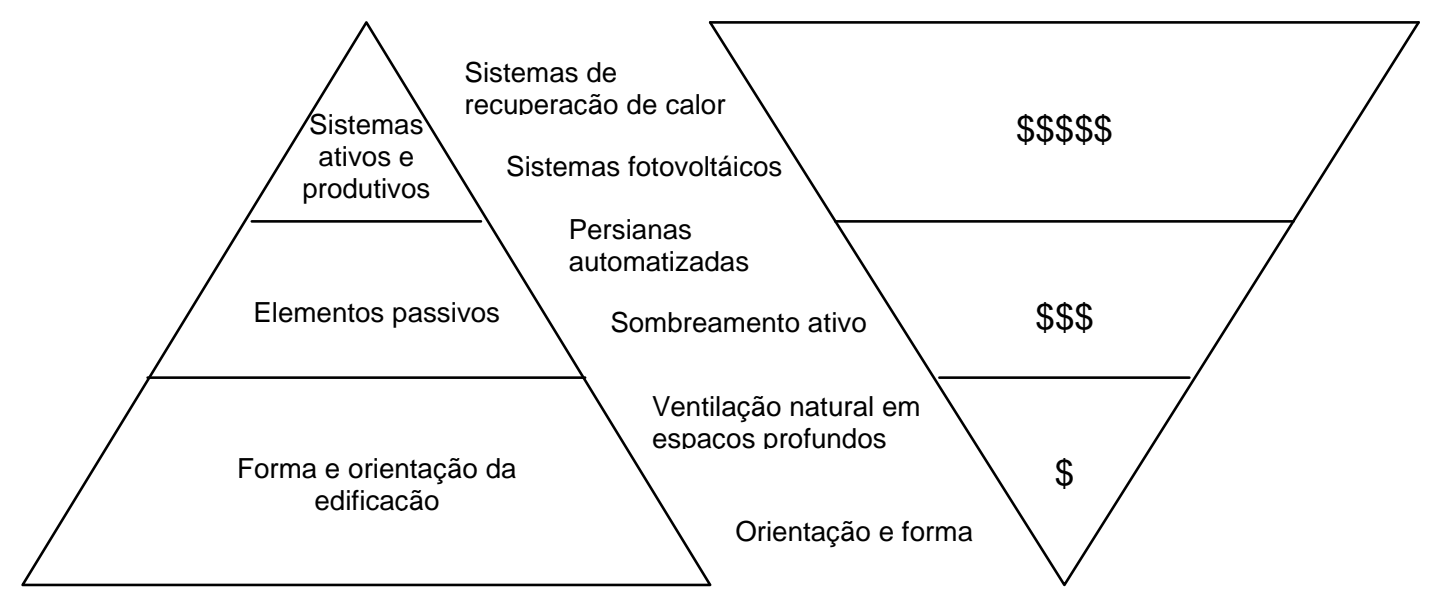

Figura 18 - Relação esquemática entre alternativas de soluções nos diferentes modos (passivo, ativo e produtivo) e impacto nos custos de implantação

Fonte: Hall; Shuttleworth e Hyams (2003)

Todos os métodos acima citados envolvem, de forma direta ou indireta, a concepção e o detalhamento das fachadas, que, por consequência, influenciam diretamente no consumo energético das edificações. Em edifícios de escritórios, este consumo é ainda mais acentuado, devido à intensa utilização de sistemas como ar condicionado, iluminação artificial, equipamentos de informática, e elevadores. Pirró (2005) verifica, em seu estudo sobre o impacto das envolventes verticais no desempenho energético de edifícios de escritórios da cidade de São Paulo, que, das tipologias de fachada estudadas, as que têm até metade de sua área envidraçada $\left(W W R^{13} 50\right)$ e que possuem dispositivos externos de sombreamento são as que apresentam melhor desempenho energético. Verifica também que estas tipologias não são necessariamente as que têm maiores custos de implantação, com exceção da tipologia de fachada dupla ${ }^{14}$, e que mesmo esta última tipologia traz economias ao longo do tempo, justificando seu custo de implantação mais alto.

13 Percentual de área envidraçada.

14 No caso do estudo trata-se de uma fachada composta por uma camada externa em cortina de vidro e uma camada interna de superfície com diferentes percentuais de vedos opacos e transparentes, separadas por um espaço de ar ventilado naturalmente. 
O aprofundamento da questão do desempenho energético das edificações traz à tona a importância de se considerar na fase de concepção do projeto a influência das fachadas nos aspectos relacionados ao conforto interno, à operação e à sustentabilidade da edificação, já que elas têm relação direta com a escolha do sistema de condicionamento do ar e do sistema de iluminação artificial, e, consequentemente, com o consumo energético ao longo do tempo. 


\subsection{CLASSIFICAÇÃO MERCADOLÓGICA DOS EDIFÍCIOS DE ESCRITÓRIOS}

As considerações-chave acima discorridas são parte essencial de atributos que classificam a qualidade do edifício de escritórios como produto. Apesar da grande diversidade de classificações existentes no mercado imobiliário (principalmente das empresas atuantes no mercado de edifícios de escritórios), a maior parte destas classificações converge nos quesitos das qualidades destes atributos, de modo a justificar um valor maior de preço de venda ou aluguel. Lajes grandes (ex: maiores que $800 \mathrm{~m}^{2}$ ), profundidade de andar rentável, boa relação entre área de locação e área construída, poucos pilares nas áreas de escritórios, pé direito mínimo de 2,70m e proporção confortável de vagas de automóveis em relação à área de locação (ex: uma vaga a cada $30 \mathrm{~m}^{2}$ ) são exemplos de atributos que compõem um edifício de escritórios com o nível mais alto de classificação (podendo ser AAA, ou A+, ou A, dependendo do tipo de sistema de classificação). Veronezi (2004) observa que não há consenso nas regras de classificação mercadológica destes edifícios e apresenta, para tanto, mais informações sobre valores de atributos e propostas para um sistema de certificação da qualidade de edifícios de escritórios, cujos principais conceitos são utilizados pelo Núcleo de Real Estate, da Escola Politécnica da USP, para prestação de serviços de avaliação e classificação mercadológica dos empreendimentos imobiliários. 


\section{ESTRUTURA}

\subsection{INTRODUÇÃO}

A concepção estrutural de um projeto nasce no projeto arquitetônico. Segundo Rebello (2001):

A concepção de uma forma implica na concepção de uma estrutura e, em conseqüência, dos materiais e processos para materializá-la. A estrutura e a forma são só um objeto e, assim sendo, conceber uma implica conceber a outra e vice-versa.

Esta concepção não exige domínio nos cálculos matemáticos, necessários para seu dimensionamento, mas domínio conceitual das forças que estão agindo naquela forma que está sendo concebida e da hierarquia de requisitos que devem ser atendidos (estéticos, de custos, de execução). Uma boa concepção estrutural no início do projeto evita futuras distorções ou desfigurações decorrentes do cálculo estrutural do mesmo.

\subsubsection{Normas aplicáveis}

Todos os projetos de estruturas de edificações estão submetidos a algum tipo de norma ou código local. Apesar de uma norma não ter o mesmo impacto que uma lei (como é o caso do zoneamento), ela é utilizada como parâmetro em casos em que há algum tipo de falha estrutural que resulta em litígio judicial.

As normas aplicáveis no Brasil para o projeto de estruturas de edificações são inúmeras, de acordo com os materiais (concreto, aço, madeira) e a técnica construtiva escolhida, sendo relacionadas abaixo as que envolvem critérios gerais de dimensionamento:

- NBR 6120 (ABNT, 1980) - Cargas para o cálculo de estrutura de edificações

- NBR 6123 (ABNT, 1988) - Forças devidas ao vento em edificações 


\subsection{CONSIDERAÇÕES CONCEITUAIS}

\subsubsection{Requisitos estruturais}

Estrutura, em arquitetura, é o sistema de material de edificação capaz de transmitir cargas e absorver esforços, de modo a garantir a estabilidade, a segurança e a integridade da construção, cooperando na sua organização espacial e na sua expressão, mediante o adequado emprego dos materiais, das técnicas, dos processos e dos recursos econômicofinanceiros (SOUTO; SILVA, 2000).

Assim, as estruturas de edificações são projetadas basicamente para resistir a cargas de forma segura e transferir estas cargas para o solo. Além das funções primordiais mencionadas na definição acima, as estruturas têm que atender a outros critérios de desempenho, tais como proteção contra fogo, níveis de vibração máximos, conforto acústico entre andares e deformação máxima de lajes. Ainda há os requisitos comerciais do edifício, que consistem em critérios específicos de carregamento, presença mínima de pilares na área de locação, peso próprio reduzido e os menores custos de implantação possíveis. A melhor solução para um projeto está, portanto, na definição da hierarquia e do equacionamento destes requisitos no sistema estrutural.

\subsubsection{Critérios de carregamento}

As cargas estruturais podem ser divididas em duas categorias: cargas permanentes e cargas acidentais (ou sobrecargas). As cargas permanentes consideram o peso próprio da estrutura e todas as cargas aplicadas constantemente sobre ela, caracterizadas pelos elementos fixos da edificação, tais como: paredes não removíveis (alvenaria ou drywall ${ }^{15}$ ), acabamentos, fachadas e esquadrias. As cargas acidentais, por sua vez, consideram todas as demais cargas que podem atuar na edificação em função de seu uso. Nesta categoria, incluem-se as cargas de móveis, divisórias removíveis, estações de trabalho, equipamentos, pessoas, veículos, variações de temperatura (carga térmica), ações naturais (vento, neve, efeitos sísmicos) e empuxos.

\footnotetext{
${ }^{15}$ Tecnologia construtiva de vedo vertical que utiliza perfis metálicos e placas de gesso acartonado.
} 
As normas locais prevêem valores mínimos para as cargas permanentes e acidentais. $\mathrm{Na}$ NBR 6120 (ABNT, 1980), por exemplo, a carga acidental prevista para área de escritórios (salas e banheiros) é de $2 \mathrm{KN} / \mathrm{m}^{2}$ (ou $200 \mathrm{Kgf} / \mathrm{m}^{2}$ ), que é bem próxima dos $244 \mathrm{Kgf} / \mathrm{m}^{2}$ (ou 50p/sf) previstos pela norma ASCE 7-05 (ASCE, 2005) para território norte-americano. Como nesta mesma norma a carga acidental para área de lobbies e corredores de andares baixos passa para o dobro do valor (cerca de $488 \mathrm{kgf} / \mathrm{m}^{2}$, arredondando para $500 \mathrm{kgf} / \mathrm{m}^{2}$ ), há empreendedores brasileiros que solicitam que ela seja considerada em todo o pavimento tipo, talvez por acreditarem que isto melhora a classificação mercadológica do empreendimento e, consequentemente, o valor de comercialização do edifício. Realmente, este incremento de carga acidental possibilita uma maior faixa de potenciais compradores ou inquilinos, pois há usos específicos de centrais de dados e alguns setores de bancos que requerem estes valores. Porém, considerando que desperdícios conceituais devem ser evitados, cabe ao projetista questionar a real necessidade de se aplicar esta carga na totalidade dos pavimentos, sugerindo, como alternativa, regiões específicas do pavimento com este critério de carga. Em projetos de edifícios de escritório, Franco (informação verbal ${ }^{16}$ ) aconselha utilizar como critério de carregamento acidental o valor mínimo estabelecido por norma brasileira acrescido de mais $100 \mathrm{kgf} / \mathrm{m}^{2}$ e, em casos muito específicos, uma faixa de dois metros ao redor do núcleo do pavimento com carga de $1.000 \mathrm{kgf} / \mathrm{m}^{2}$.

Ainda a respeito das cargas acidentais, as forças que geram cargas de ações naturais em um edifício, normalmente são originárias do vento, neve e eventos sísmicos. No Brasil, principalmente na região Sudeste, a neve e os eventos sísmicos, por serem pouco frequentes e de baixa intensidade, não são considerados no cálculo estrutural. As cargas de vento, por sua vez, além de estarem previstas em norma, tornam-se particularmente importantes em edifícios altos, por causa da área maior de atuação e pela esbelteza estrutural inerente da edificação (Figura 19).

\footnotetext{
${ }^{16}$ Informação obtida em entrevista com eng. Mário Franco, diretor da JKMF Engenharia, em 17 Fev. 2009.
} 


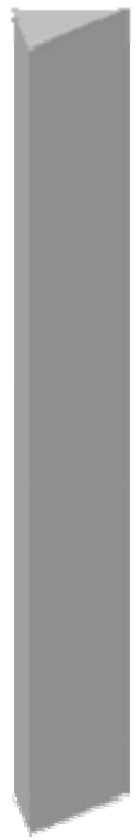

Modelo de edifício com 64 andares para teste em túnel de vento
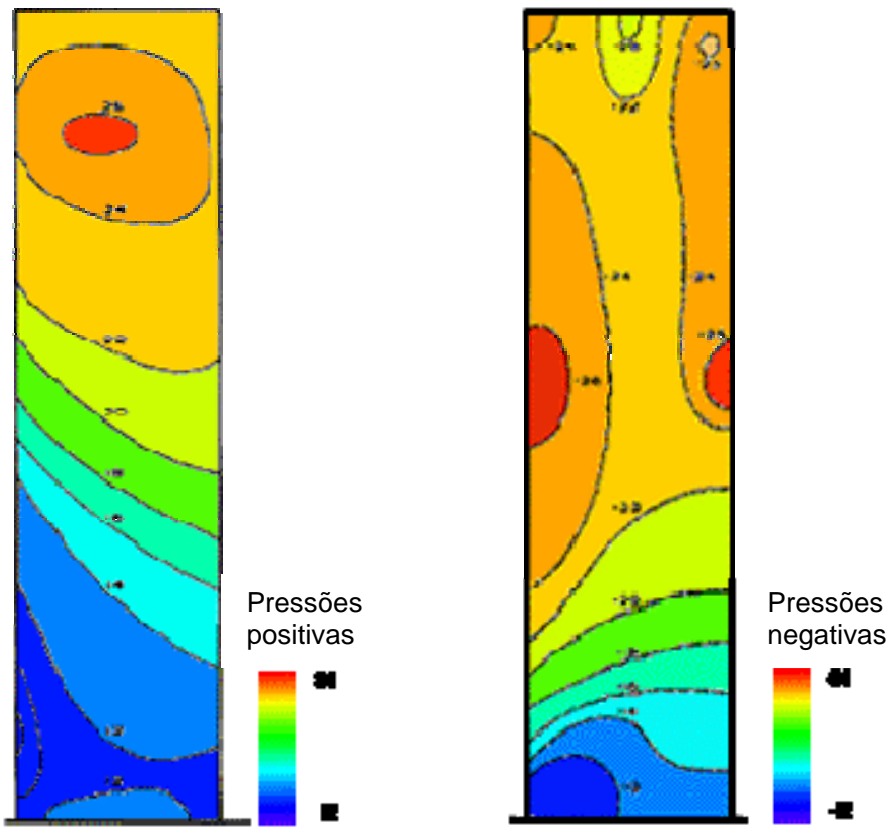

Figura 19 - Ilustração da atuação de forças de pressão de vento (positivas e negativas) em modelo de teste Fonte: http://www.cse.polyu.edu.hk/ civcal/wwwroot/superstr/curtain_wall/default.htm

Cowan (1976) afirma que o incremento da velocidade do vento é proporcional à altura do edifício e ainda influenciado pelas condições onde ele se localiza. Robertson e See (2002) comentam soluções para resistência às cargas horizontais, notadamente para estruturas metálicas, tais como paredes de travamento, núcleos reforçados e tesouras de contraventamento em andares pré-determinados. As soluções brasileiras mais comuns, particularmente na região Sudeste, envolvem a utilização de:

- Pórticos;

- Núcleos reforçados com paredes de travamento em concreto armado (Figura 20), vistos com freqüência em caixas de elevadores e de escadas;

- Geometria, dimensão e número de pilares, também de concreto armado;

- E, por fim, da própria laje, pela rigidez que proporciona. 


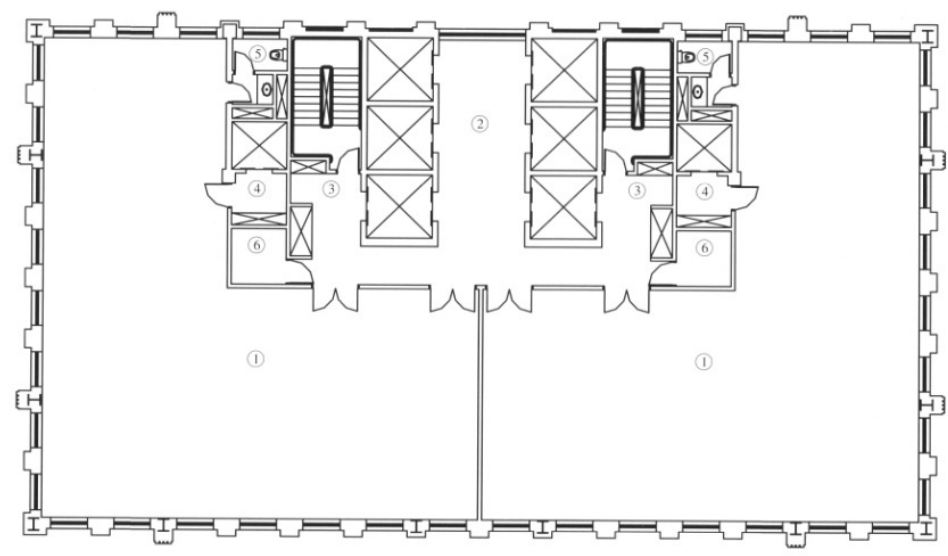

Pavimento tipo

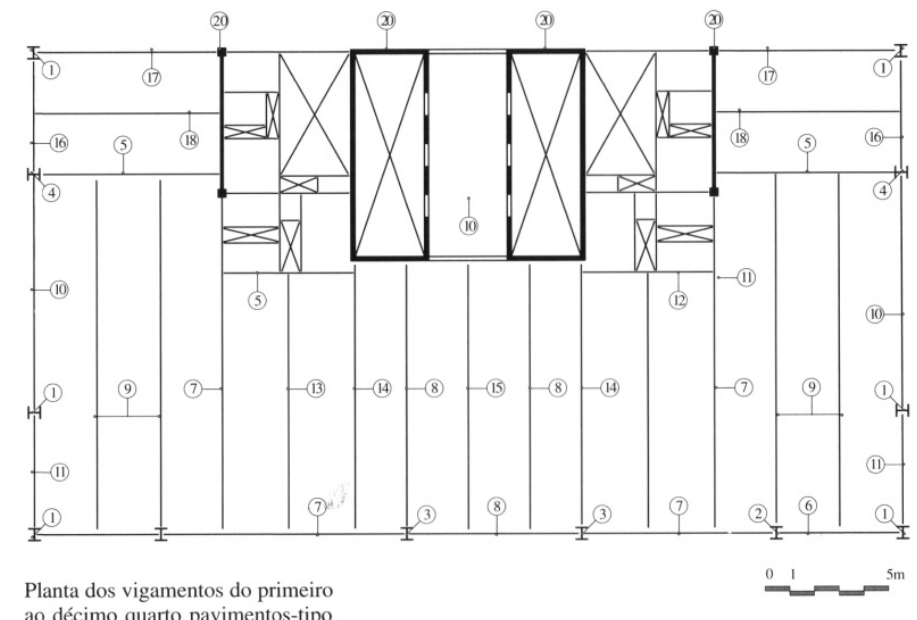

\author{
Laje estrutural, \\ indicando estrutura \\ metálica (pilares e \\ vigas) e reforço do \\ núcleo do pavimento \\ com paredes de \\ concreto armado \\ (linhas escuras) para \\ resistência às cargas \\ de vento
}

Figura 20 - llustração de pavimento tipo e respectiva laje estrutural do edifício de escritórios San Paolo (SP) Fonte: Dias (2001)

\title{
2.2.3 Tipologias
}

Há uma série de soluções e tipologias estruturais para edificações. Como a estrutura é parte inerente do aspecto do edifício, é importante que o arquiteto conheça conceitualmente estas tipologias e saiba, em termos gerais, a melhor aplicação para cada uma delas. Descrições destas tipologias e de seus diferentes materiais podem ser encontradas em Souto e Silva (2000), Cowan (1976) e Torroja (1960), e alguns cálculos e dimensionamentos iniciais podem ser consultados em Margarido (2001), principalmente para o concreto armado. Em Rebello (2000), pode-se encontrar uma abordagem bastante didática de sistemas estruturais que são considerados básicos, cujas associações permitem a criação de todas as demais 
possibilidades estruturais. Estes sistemas básicos são: o cabo, o arco, a viga de alma cheia, a treliça, a viga Vierendeel e o pilar.

Laje plana

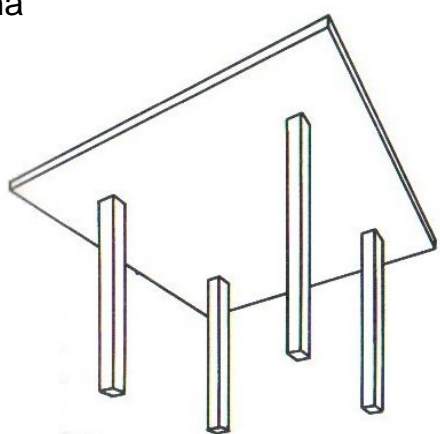

Laje nervurada

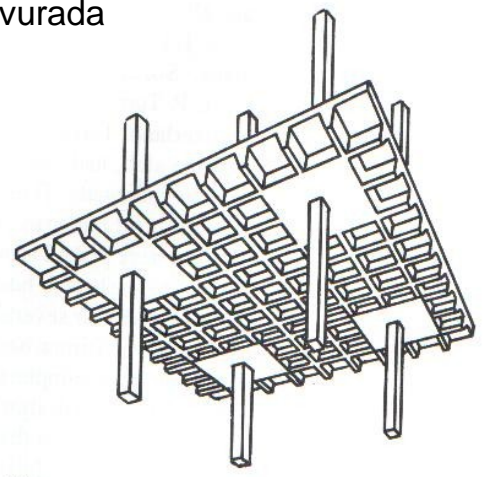

Laje com vigas

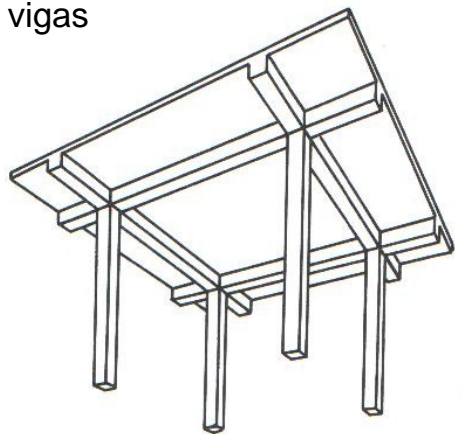

Figura 21 - Diferentes tipologias de lajes

Fonte: MacGregor (1988)

As tipologias estruturais mais comuns encontradas para o pavimento tipo de edifícios de escritórios são resultantes da associação contínua de vigas e pilares, resultando nas lajes (Figura 21), cujos arranjos típicos são comentados na Tabela 3.

Estes arranjos ainda podem considerar o uso combinado de peças para atender necessidades específicas em uma determinada tipologia, tais como aumento do vão a ser vencido, aumento de rigidez da laje, redução de altura ou número de vigas. Algumas combinações de soluções bastante comuns que podem ser citadas são: vigas de borda nas lajes planas e nervuradas, vigas protendidas nas lajes com vigas, vigas embutidas na laje nervurada, lajes protendidas, e diversas outras combinações. Para se ter uma idéia, é conveniente que lajes com vãos entre 10 e 12m, muito comuns em edifícios de escritórios de planta aberta, tenham algum tipo de protensão, seja na própria laje ou nas vigas que a apóiam. 
Tabela 3 - Características, vantagens e desvantagens de arranjos de pilares, vigas e lajes em concreto armado

\begin{tabular}{|c|c|c|c|}
\hline TIPO & CARACTERÍSTICAS & VANTAGENS & DESVANTAGENS \\
\hline $\begin{array}{l}\text { LAJE COM } \\
\text { VIGAS }\end{array}$ & $\begin{array}{l}\text { Tipologia mais usual } \\
\text { em edificações, por ser } \\
\text { econômica. Solução } \\
\text { comum para edifícios } \\
\text { de escritórios com } \\
\text { múltiplas salas. } \\
\text { Margarido (2001) } \\
\text { sugere espaçamentos } \\
\text { de } 4 \text { a } 7 \mathrm{~m} \text { entre pilares } \\
\text { como ideais. }\end{array}$ & $\begin{array}{l}\text { - Custos mais baixos. } \\
\text { - Sistema amplamente } \\
\text { difundido no mercado } \\
\text { tanto de projetos quanto } \\
\text { de construção. }\end{array}$ & $\begin{array}{l}\text { - A altura da viga é } \\
\text { proporcional ao vão entre } \\
\text { pilares, o que pode ser um } \\
\text { limitante para grandes vãos } \\
\text { (superiores a 7m) } \\
\text { - Grande quantidade de } \\
\text { pilares em pavimento tipo } \\
\text { de planta livre pode } \\
\text { prejudicar flexibilidade de } \\
\text { uso. }\end{array}$ \\
\hline LAJE PLANA & $\begin{array}{l}\text { Lajes com reforço na } \\
\text { armação para } \\
\text { compensar a ausência } \\
\text { de vigas. Normalmente } \\
\text { apresenta protensão e } \\
\text { viga de borda para } \\
\text { conferir rigidez à } \\
\text { estrutura e capitéis } \\
\text { para minimizar o efeito } \\
\text { de punção do pilar na } \\
\text { laje. }\end{array}$ & $\begin{array}{l}\text { - Permite alturas de piso a } \\
\text { piso menores. } \\
\text { - Permite a passagem } \\
\text { horizontal de sistemas } \\
\text { prediais de maior calibre } \\
\text { por ter espessura única e } \\
\text { possibilitar maior altura no } \\
\text { entreforro. }\end{array}$ & $\begin{array}{l}\text { - Aberturas nas lajes, } \\
\text { próximas aos pilares, muito } \\
\text { restritas, podendo dificultar } \\
\text { passagem de prumadas de } \\
\text { sistemas prediais. } \\
\text { - Limite de vão livre é similar } \\
\text { à da laje com vigas. }\end{array}$ \\
\hline $\begin{array}{c}\text { LAJE } \\
\text { NERVURADA }\end{array}$ & $\begin{array}{l}\text { Laje com entremeado } \\
\text { de vigas nas duas } \\
\text { direções, formando } \\
\text { uma grelha. Utiliza em } \\
\text { seu método construtivo } \\
\text { moldes de diversos } \\
\text { materiais, podendo ser } \\
\text { plástico, polipropileno, } \\
\text { isopor ou metal. }\end{array}$ & $\begin{array}{l}\text { - Melhor distribuição das } \\
\text { cargas sobre os apoios. } \\
\text { - Apresenta vantagens } \\
\text { econômicas devido à } \\
\text { relação altura/vão para } \\
\text { solicitações maiores de } \\
\text { carga. } \\
\text { - Apresenta menor peso } \\
\text { próprio em relação às } \\
\text { demais tipologias para } \\
\text { vãos próximos de 10m. }\end{array}$ & $\begin{array}{l}\text { - Não indicado para locais } \\
\text { com limitação de altura de } \\
\text { piso a piso. } \\
\text { - Solução pouco econômica } \\
\text { para vãos e cargas } \\
\text { pequenas. } \\
\text { - Aspecto estético da laje } \\
\text { pode demandar a utilização } \\
\text { de forro. }\end{array}$ \\
\hline
\end{tabular}

O material mais utilizado para estas tipologias é o concreto armado, cuja norma regente é a NBR 6118 (ABNT, 2007), e os arranjos estruturais podem ser combinados com peças em concreto armado protendido ou peças metálicas, de acordo com a necessidade do aumento de vão a ser vencido ou com a necessidade de se reduzir a altura das vigas. Comparações mais detalhadas do ponto de vista econômico e construtivo dos diversos tipos de arranjos da estrutura reticulada em concreto armado para edificações podem ser encontradas em Albuquerque (1999).

A opção, no Brasil, pelo uso em larga escala da solução estrutural em concreto armado moldado no local tem explicação, em parte, pelo seu custo comparativo menor em relação à estrutura de aço, que é outro material de excelente desempenho para sistemas estruturais, e muito utilizado em empreendimentos norte-americanos. A solução em aço, bem como a 
em concreto pré-fabricado, conta com a vantagem da rapidez da execução da obra e com a maior precisão dimensional das peças, e apresenta características executivas e de logística particulares (espaço no terreno para equipamentos de montagem, transporte das peças). Porém, uma rapidez de execução maior implica também em um desembolso financeiro para construção concentrado em um prazo menor, o que muitas vezes não é desejável para planejamentos de fluxo de caixa de empreendimentos. Além disso, o tratamento de proteção passiva contra incêndio das estruturas metálicas contribui para seu encarecimento, justificando o uso ainda relativamente restrito destas soluções estruturais nos edifícios de escritório brasileiros.

\subsection{4 Índices}

Alguns índices são interessantes para situar e eventualmente comparar estruturas de edifícios de tipologias diferentes, mas com usos e carregamentos semelhantes. Muitas construtoras, que estudam meios de baratear a execução de um projeto sem comprometer os requisitos iniciais do mesmo, utilizam os índices como balizadores para verificar o consumo relativo de materiais de execução. Os índices mais utilizados são: a espessura média da estrutura, a taxa de aço e a taxa de forma.

A espessura média da estrutura é a relação entre o consumo total de concreto e a área estrutural (somatória das áreas de plantas de forma) do edifício. A taxa de aço é a relação entre o consumo total de aço e a área estrutural do edifício. A taxa de forma é a relação entre o consumo total de forma e a área estrutural do edifício. Teoricamente, quanto menores os índices, menores são os consumos dos materiais para execução da estrutura e menores são os custos. Porém, índices nunca devem ser utilizados de forma isolada para tomadas de decisão. Uma avaliação comparativa completa de soluções estruturais deve contemplar outros fatores. Albuquerque (1999) conclui, em seu estudo comparativo de diversas tipologias de estruturas de concreto armado em edificações, que todos os aspectos pertinentes ao processo construtivo devem ser considerados (mão de obra, tempo de execução, recursos e materiais), além das implicações de cada alternativa para os demais projetos (sistemas prediais, vedações, acabamentos). 


\subsection{CONSIDERAÇÕES EXECUTIVAS NO PROJETO}

$\mathrm{O}$ arquiteto e o projetista estrutural devem entender conceitualmente o processo executivo da estrutura, de modo que, além de atender aos requisitos técnicos e estéticos, permita uma execução racional e otimizada. Isto minimiza possíveis erros de execução e melhora a produtividade em obra. Alguns exemplos de observações que facilitam a execução de estrutura de concreto armado in loco:

- Evitar peças (vigas ou pilares) com dimensões muito reduzidas. A NBR 6118 (ABNT, 2007) já prevê que dimensões inferiores a $10 \mathrm{~cm}$ sejam evitadas, pois isto dificulta a entrada do vibrador de concreto dentro da fôrma, não garantindo a distribuição uniforme de sua massa e possibilitando o aparecimento de "bicheiras".

- Evitar peças com formas geométricas muito complexas para pilares e paredes, pelo mesmo motivo exposto acima e por aumentar a demanda por trabalho artesanal (pouco conveniente em termos de produtividade) na obra para confecção das fôrmas.

- No caso estético de pilares de seção circular, verificar se os acabamentos que estes pilares receberão permitem que o mesmo seja executado em seção quadrada para depois ser "envelopado", em seção circular, pelo acabamento (bastante factível em caso de acabamento em placas de alumínio composto). O custo da fôrma circular de papelão é maior quando comparado à fôrma do pilar quadrado.

- Quando possível, conceber de forma que a malha modular da arquitetura seja compatível com a malha modular de execução da estrutura (ex: módulo das fôrmas).

- Também quando possível conceber a área de lajes de forma modular ou simétrica, permitindo que jogos de fôrma possam ter maior reaproveitamento.

A melhor produtividade em obra possibilita uma margem de erro menor no cronograma e uma melhor negociação do custo de execução da estrutura na fase de construção do empreendimento. 


\subsection{A ESTRUTURA NA CONCEPÇÃO DO EDIFÍCIO DE ESCRITÓRIOS}

No início do projeto estrutural de um edifício de escritórios, a definição das características do pavimento tipo é o principal aspecto considerado pelos projetistas estruturais. As considerações principais referem-se às seguintes questões: formato do pavimento, arranjo do núcleo, profundidade do andar, espaços reservados aos pilares, possibilidade de interligação entre andares (Figura 22) e altura de piso a piso. São itens comuns às primeiras definições do projeto de Arquitetura, o que enfatiza a importância do conhecimento de conceitos estruturais e do envolvimento de um projetista ou consultor desta área junto ao agente envolvido na concepção do projeto arquitetônico.

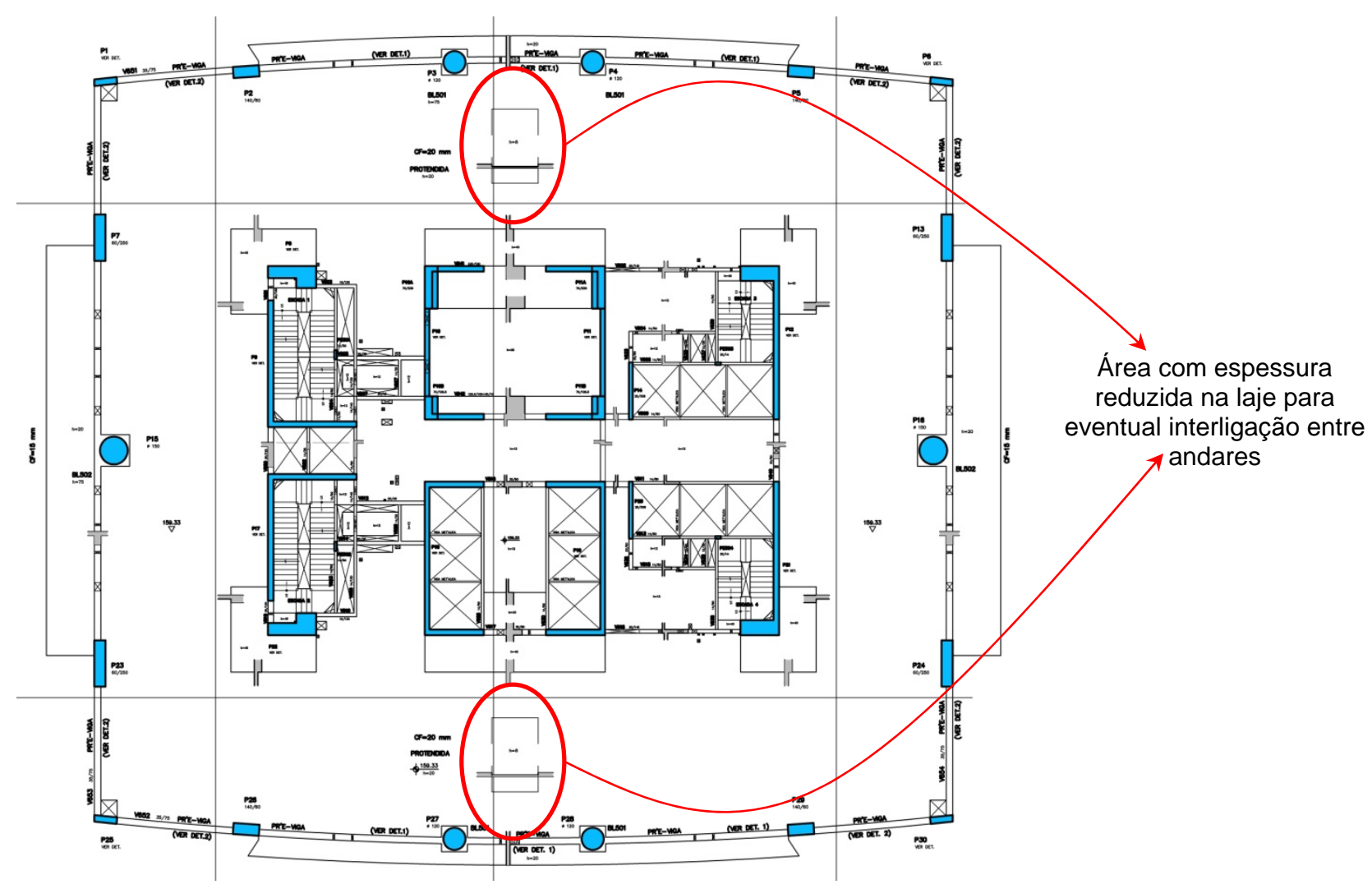

Figura 22 - Ilustração da estrutura de um pavimento tipo em laje plana, com previsão para interligação entre andares na área de escritórios 
Além disso, a definição do sistema de ar condicionado, ainda nesta fase de concepção, é vital para indicar importantes limitações e impactos aos quais está sujeito o sistema estrutural, principalmente os relacionados a percurso de dutos e localização da casa de máquinas do pavimento tipo. Ambos influenciam no uso, na altura e no posicionamento de vigas da solução estrutural.

Uma vez definido o sistema de ar condicionado, a abordagem do sistema estrutural é focada na limitação de altura de piso a piso. Isto porque, em termos gerais, quanto maior a altura da estrutura, mais econômica ela é. No caso da estrutura reticulada em concreto armado, isto é traduzido pela solução de laje com vigas. Quando alturas significativas de entreforro são requisitadas pelo sistema de ar condicionado, o conflito entre os dutos e as vigas torna-se inevitável. As possíveis soluções para este conflito são determinadas pelo equacionamento das outras condicionantes que determinam a altura de piso a piso, tais como gabaritos de altura para o edifício, o número potencial de pavimentos que podem ser comercializados e a disposição de investimento do empreendedor na solução estrutural. Alguns exemplos de soluções estruturais podem ser citados, tais como: furação das vigas para passagem de dutos, redução de altura de vigas por meio de protensão das mesmas, utilização de laje maciça plana para evitar o uso de vigas e zoneamento estratégico das vigas. Outros exemplos, que envolvem o sistema de ar condicionado, são a utilização de sistema de expansão direta com $V_{R} V^{17}$, eliminando a distribuição por dutos no entreforro, e o sistema de distribuição de ar pelo piso, que também reduz comparativamente a necessidade de altura do entreforro. Portanto, a definição da solução estrutural deve ser o resultado de um equacionamento de diversos requisitos, não necessariamente estruturais, e deve ser feita pelo projetista estrutural em conjunto com o empreendedor e o arquiteto.

\footnotetext{
${ }^{17}$ Volume de refrigerante variável.
} 


\section{SISTEMAS PREDIAIS}

\subsection{INTRODUÇÃO}

Os Sistemas Prediais de um edifício são os sistemas físicos que têm por finalidade dar suporte às atividades dos usuários, suprindo-os com os insumos necessários e propiciando os serviços requeridos (GONÇALVES, 1997 apud FARINA, 2002). Estes serviços podem ser considerados como a parte dinâmica ou operacional do edifício (sendo estática a parte física em si: estrutura, envoltória, divisões internas) e podem ser listados como: suprimento de água, energia, comunicação, conforto, segurança e transporte.

Kurtz (2002) destaca que o projeto bem sucedido destes sistemas, em edifícios de escritórios, é avaliado de acordo com sua capacidade de atingir os seguintes objetivos:

- Flexibilidade - sistemas que funcionem para diferentes tipos de usuários e que permitam adaptação ao longo da vida útil do edifício, sem perda de desempenho;

- Maximização da área de locação e da área útil ${ }^{18}$ - o comprometimento de área a ser ocupada pelas instalações deve considerar o equacionamento de seu desempenho com sua localização no edifício;

- Desempenho da infraestrutura - decorrente da crescente dependência dos edifícios de escritórios de energia e tecnologia da informação, a confiabilidade e o desempenho dos sistemas são peças-chave nos sistemas prediais, opinião também partilhada por De Martini (2008);

- Custos - o alcance dos objetivos anteriores deve equacionar os custos iniciais (execução das instalações) e os custos globais do sistema (execução das instalações, operação e manutenção dos sistemas prediais ao longo da vida útil do edifício).

Farina (2002) indica que são várias as disciplinas da Engenharia envolvidas para a concepção e domínio destes sistemas, exemplificando alguns deles e seus subsistemas correlatos na Tabela 4.

\footnotetext{
${ }^{18}$ Ver seção 1.2.1.2 deste capítulo.
} 
Tabela 4 - Exemplos de sistemas prediais e subsistemas

\begin{tabular}{ll}
\hline \multicolumn{1}{c}{ Sistemas Prediais } & \multicolumn{1}{c}{ Subsistemas } \\
\hline Sistemas de Suprimento & - Sistema de água fria \\
e Coleta da Água & - Sistema de água quente \\
& - Sistema de esgotos sanitários \\
& - Sistema de águas pluviais \\
\hline Sistemas de Conforto & - Sistema de ar condicionado \\
Térmico e Ventilação & - Sistema de iluminação \\
& - Sistema de ventilação e exaustão \\
& - Sistema de calefação \\
\hline Sistemas de Suprimento & - Sistema de gás combustível \\
e Distribuição de Energia & - Sistema de energia elétrica \\
& - Sistema de geração de energia eólica \\
& - Sistema de geração de energia solar \\
\hline Sistemas de & - Sistema de telefonia \\
Telecomunicação & - Sistema de TV \\
& - Sistema de interfonia \\
\hline Sistemas de Transporte & - Sistema de lógica ou informática \\
\hline Sistemas de Segurança & - Sistema de elevadores \\
\hline contra Incêndio & - Sistema de esteiras e escadas rolantes \\
& - Sistema de chidrantes \\
& - Sistema de detecção de fumaça e alarme \\
\hline Sistemas de Segurança & - Sistema de pressurização de escadas \\
\hline Patrimonial & - Sistema de segurança perimetral \\
\hline Sistemas de Automação & - Sistema de controle de acesso \\
Predial & - Sistema de integração de sistemas de segurança \\
& - Sistema de controle de sistemas de iluminação, som e imagem \\
& - Sistema de controle e monitoramento de elevadores \\
\hline & condicionado monitoramento dos sistemas hidráulicos e de ar \\
\hline
\end{tabular}

Fonte: FARINA (2002)

A quantidade, o escopo de cada disciplina e a especialização dos consultores em alguns subsistemas torna a contratação dos projetos de Sistemas Prediais a mais passível de sofrer erros de abrangência de escopo (lacunas de contratação ou contratação tardia). Utilizando a Tabela 4 como exemplo, observamos que em apenas um sistema, o de segurança contra incêndio, há o envolvimento de pelo menos três categorias de projetos: os sistemas de hidrantes e chuveiros automáticos estão nos projetos de instalações hidráulicas; o sistema de detecção e alarme, no projeto de instalações elétricas; e o sistema de pressurização de escadas, no projeto de ar condicionado. No edifício de escritórios, o cuidado com esta abrangência deve ser ainda maior, com a crescente evolução dos sistemas relacionados à tecnologia da informação e seus respectivos requisitos em infraestrutura dos sistemas prediais. 
Os sistemas prediais também afetam as ocupações de espaços e têm interfaces entre si e com a parte estática do edifício. Farina (2002) enumera algumas destas interfaces no início do projeto, em uma etapa inicial denominada de Estudo Preliminar, de modo a ilustrar o conceito sistêmico que deve ser dado aos projetos destes sistemas (Tabela 5).

Nas subseções que seguem, são discorridos os conceitos de cada disciplina dos sistemas prediais, considerando seus principais requisitos de projeto e as influências de suas soluções sobre o projeto arquitetônico e estrutural.

Tabela 5 - Interfaces do Estudo Preliminar dos sistemas prediais e demais componentes do edifício

\begin{tabular}{|c|c|c|}
\hline SIST. PREDIAL & ESTUDO PRELIMINAR & VARIÁVEIS DO EDIFÍCIO \\
\hline $\begin{array}{l}\text { Água fria } \\
\text { Incêndio } \\
\text { Ar condicionado }\end{array}$ & $\begin{array}{l}\text { - Volume de reservatórios } \\
\text { - Altura do reservatório superior }\end{array}$ & $\begin{array}{l}\text { - Altura do edifício } \\
\text { - Carregamento na estrutura } \\
\text { - Consumo de energia }\end{array}$ \\
\hline $\begin{array}{l}\text { Água fria } \\
\text { Água quente } \\
\text { Esgoto } \\
\text { Água pluvial } \\
\text { Energia elétrica } \\
\text { Gás } \\
\text { Telefonia } \\
\text { Ar condicionado }\end{array}$ & $\begin{array}{l}\text { - Posicionamento de prumadas e } \\
\text { dutos } \\
\text { - Definição do número de } \\
\text { prumadas e dutos } \\
\text { - Estimativa dos diâmetros das } \\
\text { prumadas e dimensões dos dutos }\end{array}$ & $\begin{array}{l}\text { - Área útil dos pavimentos } \\
\text { - Área útil de subsolos } \\
\text { - Resistência dos elementos estruturais } \\
\text { - Espessuras de paredes } \\
\text { - Tamanho dos vazios (shafts) } \\
\text { - Altura de forros }\end{array}$ \\
\hline $\begin{array}{l}\text { Água fria } \\
\text { Água quente } \\
\text { Gás }\end{array}$ & $\begin{array}{l}\text { - Tipo de distribuição (coletiva ou } \\
\text { individualizada) }\end{array}$ & $\begin{array}{l}\text { - Área e configuração de núcleo dos } \\
\text { pavimentos } \\
\text { - Áreas de administração } \\
\text { - Consumo de energia }\end{array}$ \\
\hline Incêndio & $\begin{array}{l}\text { - Posição de hidrantes } \\
\text { - Reserva de incêndio } \\
\text { - Chuveiros automáticos }\end{array}$ & $\begin{array}{l}\text { - Área e configuração de núcleo dos } \\
\text { pavimentos } \\
\text { - Área de reservatórios } \\
\text { - Áreas de administração }\end{array}$ \\
\hline $\begin{array}{l}\text { Esgoto } \\
\text { Água pluvial }\end{array}$ & - Cotas de descargas dos efluentes & $\begin{array}{l}\text { - Consumo de energia } \\
\text { - Pé direito útil de subsolos } \\
\text { - Flexibilidade de configuração de áreas } \\
\text { molhadas nos pavimentos }\end{array}$ \\
\hline Energ & $\begin{array}{l}\text { - Centro de medição } \\
\text { - Entrada de energia } \\
\text { - Prumada de energia }\end{array}$ & $\begin{array}{l}\text { - Área útil do embasamento } \\
\text { - Área e configuração de núcleo dos } \\
\text { pavimentos }\end{array}$ \\
\hline
\end{tabular}




\subsection{SISTEMAS DE AR CONDICIONADO E VENTILAÇÃO MECÂNICA}

O ar condicionado em edifícios de escritórios está diretamente ligado ao conforto térmico, que é uma sensação subjetiva, dependente de fatores tais como: radiação solar, temperatura, umidade relativa e velocidade do ar, temperatura radiante, atividade e vestimenta dos usuários, hábitos e culturas locais, entre outros. O conforto térmico pode ser definido como "o estado mental que expressa satisfação com o ambiente térmico" (ASHRAE, 2005).

O condicionamento do ar, para fins de conforto, é uma forma ativa de se controlar as condições térmicas e de umidade do ambiente interno da edificação, de maneira que estas condições internas fiquem independentes das condições climáticas externas e proporcionando conforto térmico para seus ocupantes. Segundo Hernandez Neto e Vittorino (2003), os objetivos deste sistema, em relação ao ar ambiente, podem ser:

- Resfriar ou aquecer;

- Umidificar ou desumidificar;

- Distribuir;

- Filtrar;

- Renovar.

As condições higro-térmicas desejadas para o ambiente interno, que determinam o seu grau de conforto e que são premissas de projeto, variam significativamente de acordo com o uso do ambiente e com a cultura local. Lobbies, salas de escritórios e de reuniões requerem um condicionamento maior que sanitários, garagens e áreas técnicas. Uma área de escritório pode ter requisitos diferentes de temperatura e umidade se locado em um país asiático, europeu, nos EUA ou no Brasil. Em países como China e Japão, é culturalmente aceitável e desejável que, no verão, as pessoas trabalhem, nos ambientes de escritórios, sem gravata e com camisas de manga curta, de maneira a aceitar temperaturas internas mais elevadas. $O$ padrão europeu, especificamente o alemão, admite também edifícios naturalmente ventilados, com uso mínimo do condicionamento tanto para aquecimento quanto resfriamento. Já nos EUA, prevalece a cultura do condicionamento total, na qual o usuário não tem sequer a liberdade de operar a abertura de janelas, às vezes até de persianas, ficando isto a cargo do administrador do edifício. Mesmo no Brasil, as diferenças de requisitos regionais são bastante relevantes. Portanto, as definições das premissas de 
projeto, baseadas nas necessidades locais, são muito importantes para definir o melhor sistema em termos de desempenho, consumo de energia e custos.

Um bom projeto de ar condicionado é aquele que é o mais adequado para o clima e o uso da edificação, proporcionando condições favoráveis para processos produtivos e de conforto térmico aos usuários, e equacionando estes requisitos com uma boa relação custo-benefício de implantação e operação. Portanto, o bom projeto de ar condicionado já nasce na própria arquitetura, quando são definidos elementos cruciais, tais como a orientação solar do edifício, os recuos, a ventilação natural, os materiais da envoltória (fachadas e coberturas), os elementos de proteção (tais como brises) e as aberturas. Um bom desempenho térmico passivo do edifício requer uma instalação de ar condicionado menos robusta e, conseqüentemente, com menores custos de implantação e operação.

Um sistema de ar condicionado com baixo custo de implantação não tem necessariamente baixo custo de operação. É necessário que se faça, junto ao consultor de instalações mecânicas, um estudo de custos globais e consumo de energia ao longo do tempo. Infelizmente, observam-se práticas de mercado em que o empreendedor preocupa-se somente com o custo de implantação, deixando para o futuro condomínio a preocupação com os custos posteriores. Estas práticas são danosas a médio e longo prazo, pois a maior parte do custo de um edifício de escritórios, ao longo de toda a sua vida útil, é na sua operação e manutenção ${ }^{19}$. Além do mais, um alto custo relativo de condomínio desvaloriza comercialmente o edifício de escritório. Isto já não ocorre com corporações que constroem suas próprias sedes e com empreendedores que também são administradores prediais, dada a necessidade direta de controlar seus custos de operação. Espera-se que o aumento da consciência ambiental, que envolve necessariamente a redução do consumo de recursos (água e energia), aliado ao seu crescente custo, reduza estas práticas com visão de curto prazo.

O conceito de funcionamento do sistema de ar condicionado sobre o qual discorremos neste capítulo é praticamente sobre resfriamento, por se tratar de uma ação dificilmente resolvida por métodos passivos e por ser responsável por grandes interferências físicas no projeto de arquitetura e de estrutura. Uma vez resolvido este sistema, o de aquecimento passa a ter soluções mais simples.

${ }^{19}$ Ver seção 3.3 do capítulo C. 


\subsubsection{Normas}

As recomendações para o projeto ar de condicionado nos edifícios são regidas pela norma NBR 16401 (ABNT, 2008), além de código de obras e especificidades do município. Na cidade do Rio de Janeiro, por exemplo, há uma aprovação legal específica para este tipo de projeto, o que já não ocorre na cidade de São Paulo.

\subsubsection{Premissas de projeto}

Primeiramente, definem-se os ambientes que serão condicionados, ventilados mecanicamente, ventilados naturalmente e os que terão combinações de efeitos. Esta definição geralmente é feita pelo arquiteto em conjunto com o empreendedor, com o propósito de equilibrar o projeto e os interesses de mercado. Alguns escritórios de arquitetura norte-americanos utilizam matrizes para formalizar estas definições, dado o tamanho e a complexidade de alguns projetos. O consultor de instalações mecânicas verifica conceitualmente estas definições e aponta sugestões de modificação. O condicionamento da sala de baterias para alimentar sistemas de no-breaks em edifícios comerciais é um exemplo citado por Grecco (informação verbal ${ }^{20}$ ). Como se trata de uma área técnica, a sala de baterias é inicialmente desprezada para receber qualquer tipo de condicionamento de ar. Contudo, o resfriamento deste local possibilita o aumento da vida útil das baterias, e pode ser resolvido com um equipamento relativamente simples e de baixo investimento.

$\mathrm{Na}$ parte de cálculo, que é feita pelo consultor de instalações mecânicas, adotam-se premissas de temperaturas de conforto (Tabela 6) e de cargas térmicas externas (transmitidas pela envoltória e pelo ar externo) e internas, oriundas de: densidade populacional, lâmpadas, reatores e equipamentos de escritório. Valores muito utilizados para os cálculos preliminares são: uma pessoa a cada 6 a 10m²; 20 a 25w/m² para lâmpadas e 30 a 45w/m² para equipamentos (KURTZ, 2002, GRECCO, informação verbal $\left.^{19}\right)$.

${ }^{20}$ Informação obtida em entrevista com eng. Eduardo Grecco, diretor da Contractors Engenharia, em 11 Dez. 2008. 
Com estes dados, o consultor de instalações mecânicas faz o cálculo teórico da carga térmica total da edificação (expressa em $\mathrm{TRs}^{21}$ ), e propõe alternativas de sistemas mais adequados ao uso, com suas vantagens e desvantagens, incluindo os aspectos qualitativos relacionados a: vida útil do sistema, custos de operação e de manutenção.

Tabela 6 - Temperaturas internas de conforto

\begin{tabular}{lcc}
\hline & Verão & Inverno \\
\hline Temperatura bulbo seco & $23^{\circ}$ a $26^{\circ} \mathrm{C}$ & $21,5^{\circ}$ a $24^{\circ} \mathrm{C}$ \\
\hline Temperatura bulbo úmido & $22,5^{\circ}$ a $25,5^{\circ} \mathrm{C}$ & $21^{\circ}$ a $23,5^{\circ} \mathrm{C}$ \\
\hline
\end{tabular}

Fonte: NBR 16401-2 (ABNT, 2008)

Existem também disponíveis no mercado diversos softwares que fazem a simulação computacional do balanço energético do edifício (o EnergyPlus é um deles). Estes softwares consideram diversas variáveis, desde a carta climática da região de implantação do edifício, sua orientação solar, situação de ventos, tipos e quantidades de aberturas na envoltória, materiais da envoltória e tipos de luminárias, entre outros. A alimentação de dados para este tipo de simulação envolve uma complexidade proporcional à precisão que se deseja dos resultados finais. Um deles é a real carga térmica que deve ser combatida pelos sistemas ativos. Por envolver uma precisão maior deste valor em relação ao cálculo teórico, estas simulações computacionais, quando bem feitas, podem otimizar o dimensionamento do sistema de ar condicionado.

\subsubsection{Funcionamento conceitual do sistema}

Segundo Hernandez Neto e Vittorino (2003), o ar é insuflado no ambiente em condições de temperatura, umidade e pureza diferentes daquelas que se quer manter. Este ar se mistura ao do ambiente, resultando nas condições definidas em projeto. Como exemplo, no caso de remoção de calor em ambientes internos (sendo este calor gerado pelo próprio uso do ambiente e pela parcela que penetra pela envoltória do edifício), o ar é insuflado com temperatura cerca de $10^{\circ} \mathrm{C}$ a $12^{\circ} \mathrm{C}$ mais baixa do que a desejada.

21 TR: Tonelada de refrigeração - unidade que expressa a capacidade de refrigeração de equipamentos de ar condicionado. Uma TR equivale a 12.000 BTUs/hora. 
Esquematicamente (Figura 23), o sistema funciona com os seguintes elementos: uma tomada de ar externo, um equipamento de resfriamento, o ambiente que se deseja condicionar, uma exaustão de ar, uma unidade de recuperação de energia e as ligações entre estes elementos por meio de dutos. O equipamento faz o resfriamento do ar que é tomado externamente; o ar de retorno é, em parte, recirculado e, em parte, exaurido. Parte do ar exaurido é utilizado para pré-resfriar o ar externo, de modo a reduzir o trabalho do equipamento de resfriamento. A unidade de recuperação de energia é o elemento que faz esta troca de calor.

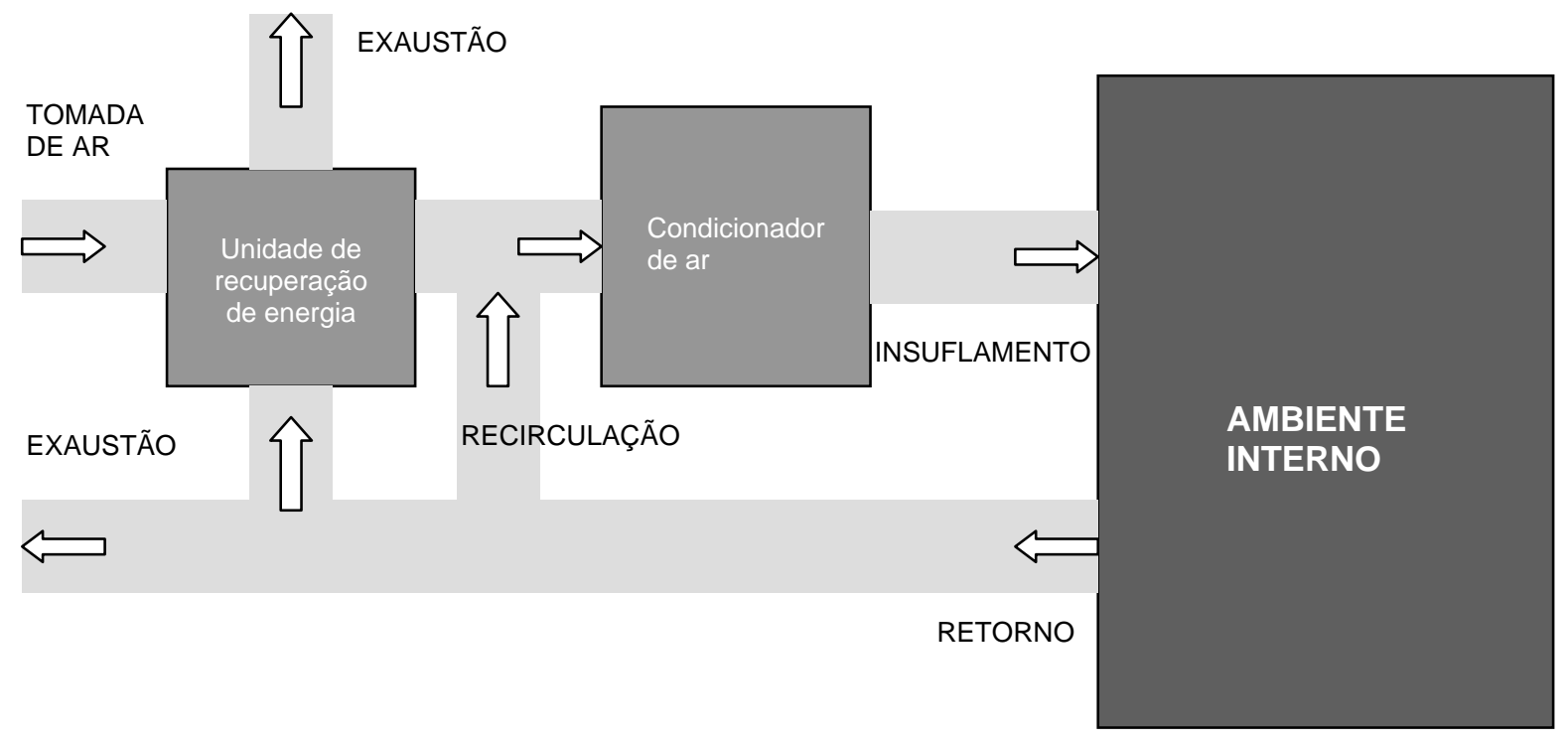

Figura 23 - Esquema de resfriamento de ambientes

Fonte: Hernandez Neto; Vittorino (2003)

\subsubsection{Principais componentes do condicionador de ar}

Os principais componentes conceituais do condicionador de ar são:

- Evaporador: elemento que retira o calor do ambiente pela evaporação de um gás (em estado líquido) a baixas pressões;

- Compressor: fornece a energia mecânica para o funcionamento do sistema e comprime o gás de modo a elevar sua pressão;

- Condensador: rejeita para o exterior o calor retirado do ambiente, por meio da condensação do gás, que volta ao estado líquido; 
- Válvula de expansão: reduz a pressão do líquido de modo a adequá-lo ao recomeço do ciclo, pronto para ser evaporado novamente.

\subsubsection{Tipos de sistemas}

A classificação dos tipos de sistemas pode variar em função do meio utilizado para fazer a troca de calor do fluido refrigerante ou em função do sistema de distribuição. Stoecker e Jones (1985) dividem os sistemas de distribuição em: sistemas de zona simples (utilizados em auditórios e laboratórios, em que condições térmicas devem ser mantidas com rigor), sistemas de múltiplas zonas (utilizados nos edifícios de escritórios em geral), e sistemas unitários. Hernandez Neto e Vittorino (2003) classificam os sistemas em quatro tipos básicos, apresentados abaixo, em função de como o ambiente é resfriado ou aquecido: expansão direta no ambiente, sistemas todo ar, sistemas todo água e sistemas ar-água.

\section{Expansão direta no ambiente}

Sistema unitário, cujo equipamento autônomo contém todos os componentes necessários (evaporador, compressor, condensador e válvula de expansão) para resfriar e trocar o ar, sendo que esta ação é feita por meio de troca de calor direta do ar com o fluido refrigerante. Como exemplos deste tipo de sistema, temos os condicionadores de janela e os sistemas divididos (split). Estes sistemas funcionam bem em pequenos ambientes, têm custo relativamente baixo e são de fácil instalação, porém oferecem pouca versatilidade em termos de capacidade e de controles. Seu uso indiscriminado em edifícios de escritórios representa desperdício de energia e a maior parte dos equipamentos tipo "mini-split" não permite a renovação do ar interno.

\section{Sistema todo ar}

É um sistema de condicionamento de ar, em que evaporador e condensador utilizam o ar como meio de transferência do calor do fluido refrigerante. A mistura do ar pode ser feita no próprio equipamento de resfriamento (no caso, um "self-contained") ou em unidades misturadoras específicas $\left(A H U^{22}\right)$. A distribuição do ar resfriado pode ser feita por evaporadores distribuídos ao longo do forro dos andares ou por meio de dutos. Neste caso,

\footnotetext{
${ }^{22}$ Air Handling Unit - unidade misturadora de ar.
} 
o equipamento de resfriamento é locado não muito distante do andar condicionado para evitar grandes percursos horizontais e verticais de dutos, seja de fluido refrigerante ou de ar. Dependendo da geometria do andar e da localização do equipamento (ex: extremo de um dos lados), o balanceamento da temperatura do andar (muito frio próximo ao equipamento e pouco frio distante dele) e o retorno do ar resfriado pode ser dificultado.

\section{Sistema todo água}

É um sistema de condicionamento de ar central, também conhecido como sistema de expansão indireta (Figura 24), em que evaporador e condensador utilizam água ou água com sais como meio de transferência do calor do fluido refrigerante. Este sistema requer subsistemas hidráulicos (Figura 25), compostos por planta de água gelada e torre de resfriamento.

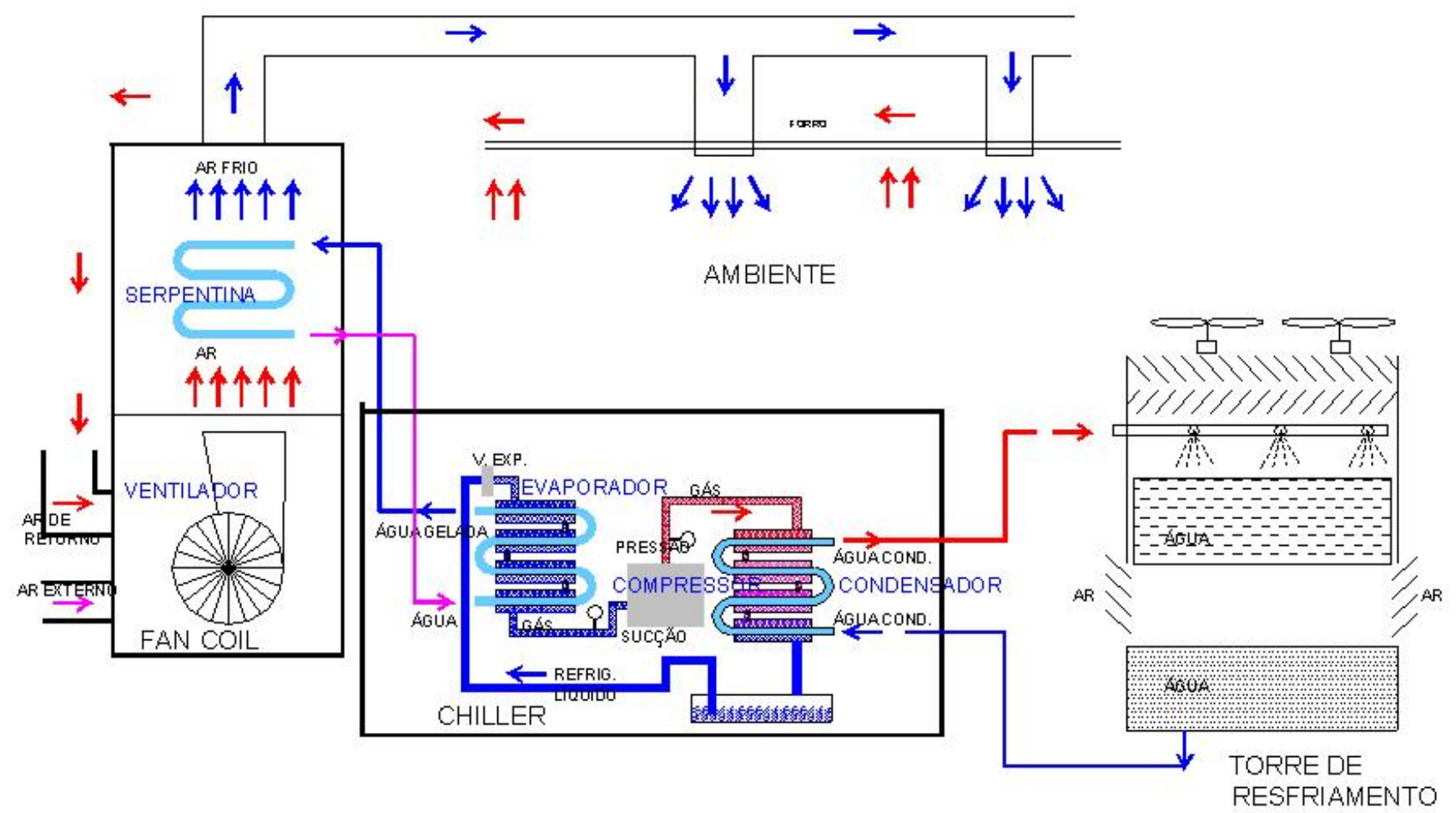

Figura 24 - Sistema de expansão indireta

Fonte: Leite (2009)

A planta de água gelada permite que o equipamento de resfriamento (chiller) fique distante do andar ou local condicionado, o que é uma vantagem em termos de liberação de área útil nos pavimentos. Ela pode contar ou não com um sistema de termoacumulação, que permite a redução da capacidade total do equipamento de resfriamento, mas que também implica 
em maiores espaços demandados pelo sistema para os reservatórios de água gelada ou gelo. O fornecimento de água gelada pelo sistema possibilita a sua medição individualizada e o rateio proporcional de custos de ar condicionado entre os usuários.

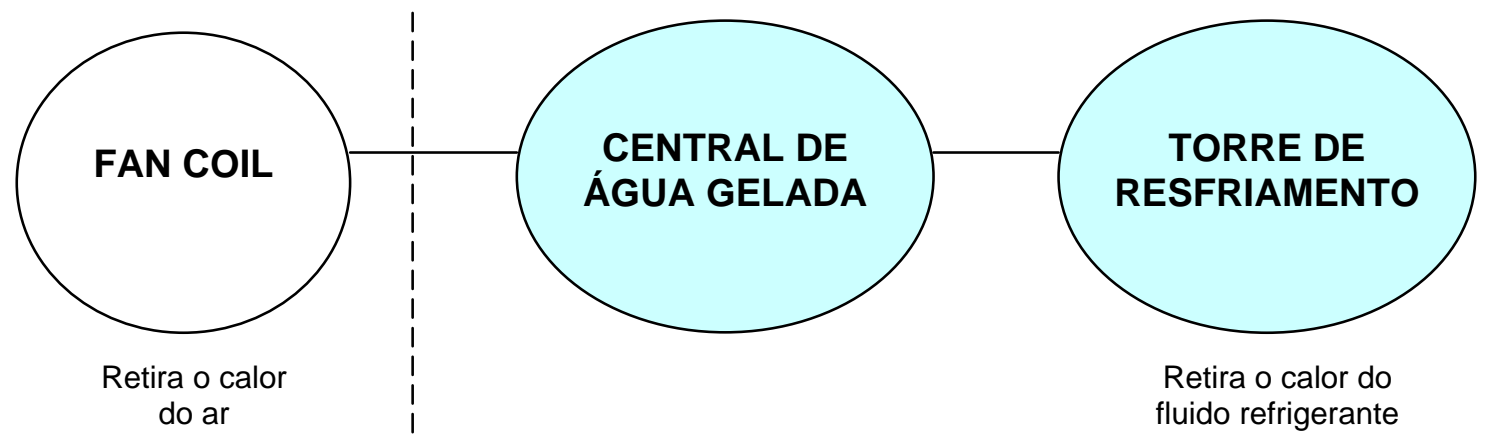

Figura 25 - Esquema hidráulico do sistema de expansão indireta

Fonte: Leite (informação verbal ${ }^{23}$ )

A torre de resfriamento, por sua vez, demanda grandes espaços descobertos para transferência do calor e é um grande centro consumidor de água, uma vez que a maior parte dela é perdida no processo pela evaporação. Esta demanda por espaços, aliada a necessidades de máximo aproveitamento de áreas comercializáveis, faz que este sistema hidráulico seja preferencialmente localizado nas coberturas dos edifícios de escritórios.

As unidades misturadoras de ar, neste sistema, recebem água gelada do equipamento central e denominam-se fan coils. Geralmente ficam localizadas em salas específicas no núcleo do pavimento, e interferem diretamente no arranjo de vigas estruturais, por necessitarem de dutos de grandes dimensões em suas saídas. Além disso, estas salas devem contar com sistemas de drenagem para a água de condensação que se forma na serpentina do fan coil, que devem ser previstos no projeto de sistemas prediais hidráulicos.

\section{Sistema ar-água}

É um sistema de condicionamento de ar central, em que um dos componentes do equipamento de resfriamento (evaporador ou condensador) usa ar, enquanto o outro usa água como meio de transferência de calor do fluido refrigerante. Este sistema requer apenas um dos subsistemas hidráulicos mencionados no sistema todo-água.

\footnotetext{
${ }^{23}$ Informação obtida junto à prof. Brenda C. C. Leite, em 27 Mar. 2009.
} 


\subsubsection{Componentes típicos e demanda de espaços}

As dimensões, localizações e requisitos especiais dos espaços dos equipamentos típicos variam de acordo com as características dos edifícios e do sistema utilizado. Os componentes mais significativos podem ser citados como: resfriadores (chillers), dutos de ar, ventiladores (AHUs ou fan coils), bombas e controles. Os ambientes onde ficam os resfriadores e ventiladores possuem requisitos especiais de proteção acústica e contra incêndio, e devem contar com um sistema de drenagem para a água de condensação. Os dutos de ar, que influenciam diretamente na altura do entreforro e do sistema estrutural, também devem contar com cuidados de proteção acústica. Todos os acessos a ambientes com equipamentos ou componentes de sistemas de ar condicionado (portas, alçapões, placas de forro) devem ser previstos com dimensões suficientes para a passagem dos mesmos, além das pessoas que irão realizar sua operação, em caso de necessidade de troca ou manutenção externa.

Como cada sistema é customizado em função das necessidades e características de cada empreendimento, os espaços demandados mais significativos pelos equipamentos de ar condicionado estão exemplificados nos empreendimentos do estudo de caso (seções 4.1.1, 4.2.1 e 4.3.1 do capítulo D).

\subsubsection{Tipo de distribuição e retorno}

Os equipamentos de expansão direta, por condicionarem recintos pequenos e estarem localizados nos mesmos, não necessitam de elementos externos de distribuição do ar frio e retorno do ar resfriado. Estes ocorrem nos sistemas centrais, e sua distribuição pode ser dividida em dois tipos: pelo forro e pelo piso.

\section{Distribuição pelo forro}

Os caminhamentos, tanto o ar frio como o ar de retorno, ocorrem pelo forro. A distribuição do ar frio é feita por meio de dutos, que podem ser aparentes no teto ou embutidos no forro. Quando embutidos, os dutos são dotados de uma camada de isolamento térmico, o que aumenta suas dimensões em termos de espaços ocupados. 
Os terminais dos dutos são as grelhas, por onde o ar frio é incorporado ao ambiente. O ar de retorno passa pelo forro por meio de dutos ou utilizando o próprio forro como um plenum (Figura 26).

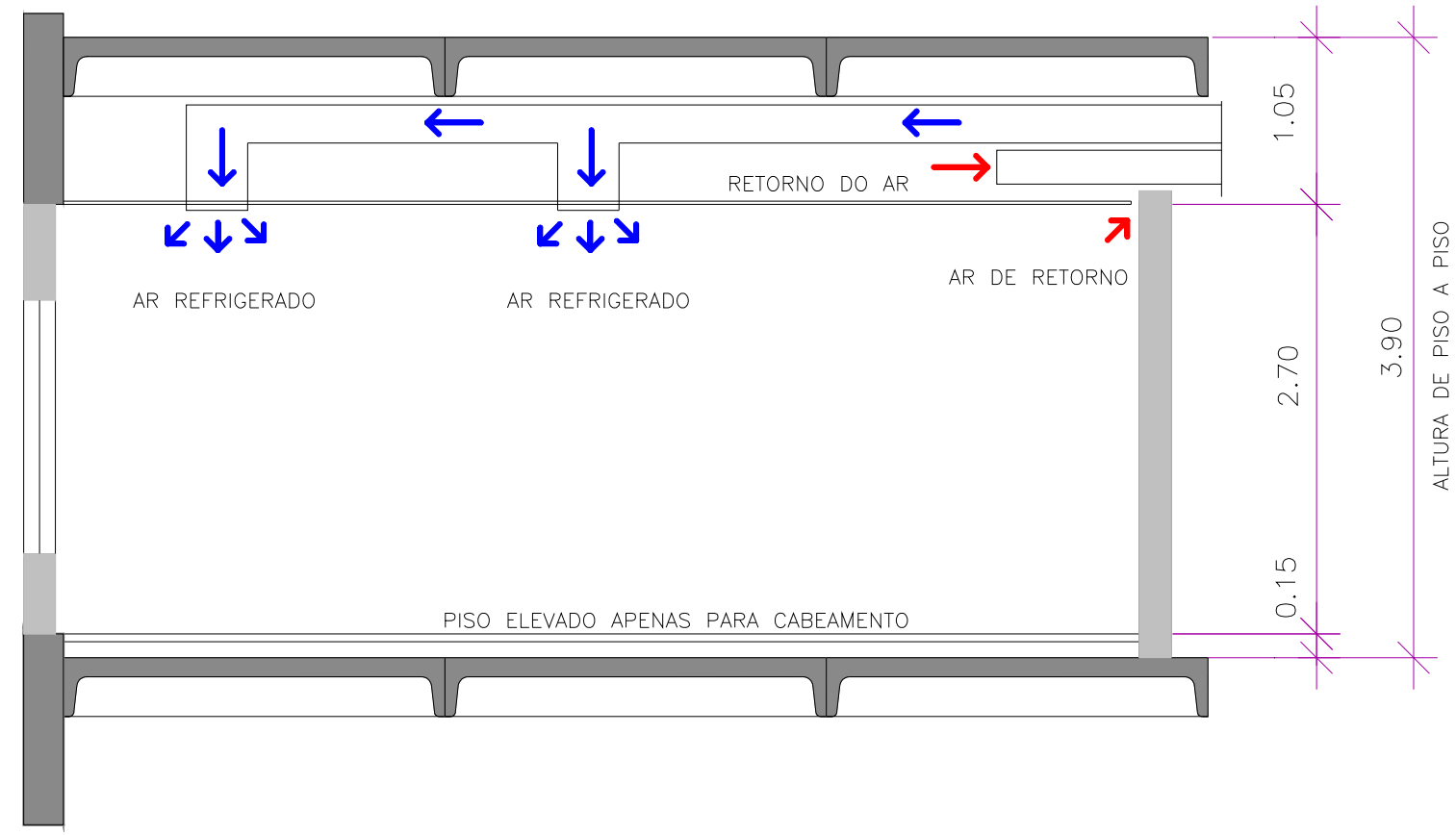

Figura 26 - Desenho esquemático de distribuição do ar condicionado pelo forro

\section{Distribuição pelo piso}

O sistema de distribuição pelo piso é relativamente novo e exige a consideração de piso elevado nos pavimentos condicionados. O espaço interno do piso elevado funciona como um grande plenum de ar refrigerado, com leve pressão positiva, e de onde o ar passa ao ambiente por meio de distribuidores de piso ou distribuidores de mesa. Estes distribuidores, por estarem incorporados à placa do piso elevado, podem ser remanejados com certa facilidade, de acordo com as necessidades do lay-out do ambiente. $O$ ar frio tende naturalmente a permanecer mais próximo ao piso e, conforme ele se aquece com o decorrer do uso do ambiente, sobe pelo efeito da convecção e é captado por aberturas no forro (Figura 27). 


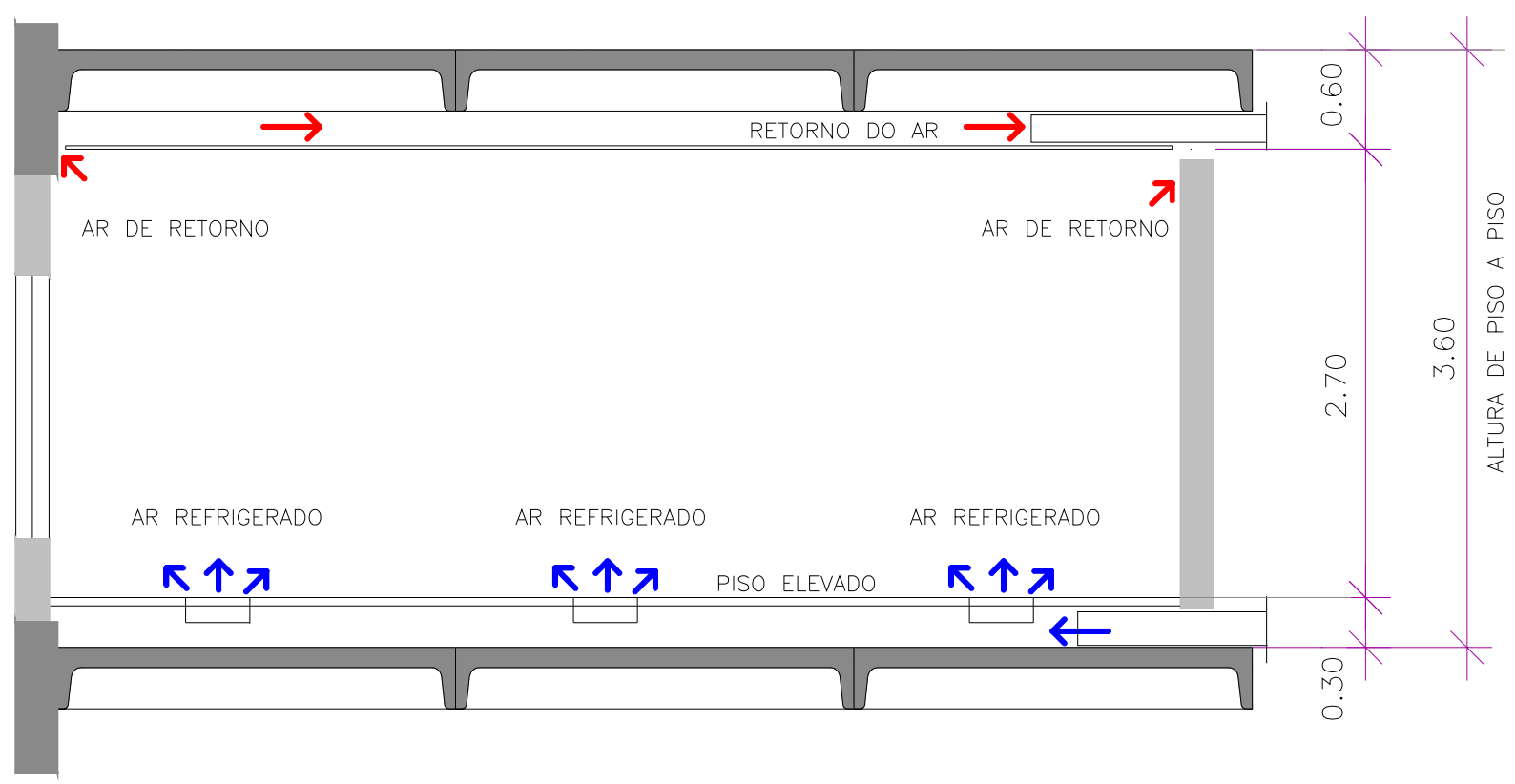

Figura 27 - Desenho esquemático de distribuição do ar condicionado pelo piso

A distribuição pelo piso é defendida por alguns como conceitualmente mais lógica, por considerar o fenômeno da extratificação do ar e diminuir comparativamente a carga térmica a ser vencida, já que o volume condicionado é menor (ar frio somente na zona ocupada, nos primeiros dois metros de altura, e não em todo o volume do ambiente) e o perfil de temperatura permite que o ar insuflado tenha uma temperatura superior ao do sistema de distribuição pelo forro, indicando economia de energia do sistema. Para este, Leite (2003) recomenda parâmetros de projeto baseados nas características de uso e operação, para atendimento a condições de conforto térmico, e enumera alguns principais aspectos, tanto positivos quanto negativos, tais como:

- A temperatura do ar insuflado no ambiente é mais alta do que a do ar fornecido pelo sistema de distribuição pelo forro;

- O sistema tende a consumir menos energia do que um convencional, por insuflar ar menos refrigerado e por condicionar um volume menor de ar;

- O sistema permite a redução da altura de piso a piso dos edifícios, pelo ganho de espaço no entreforro com a ausência de dutos e dá flexibilidade a soluções estruturais mais econômicas;

- O sistema não é recomendado em áreas suscetíveis à água, e exige um maior controle na desumidificação do ar. 
A não observância de cuidados na implantação e operação deste sistema pode acarretar na insatisfação dos usuários, sob forma de desconforto com correntes de ar e "frio nos pés", e consequentemente na rejeição do mesmo como um todo.

A determinação do tipo de distribuição do ar condicionado, portanto, relaciona-se com a solução arquitetônica e estrutural do edifício de escritórios, à medida que os espaços ocupados pelos dutos, na distribuição pelo forro, influenciam diretamente no resultado da altura de piso a piso dos pavimentos ${ }^{24}$.

\subsubsection{Impacto no consumo de energia elétrica}

O ar condicionado é o grande consumidor de energia elétrica em edifícios de escritórios, sendo responsável por uma fatia da ordem de $40 \%$ a $60 \%$, dependendo das condições climáticas e do tipo de sistema utilizado. Além disso, a tarifação de energia para edifícios comerciais, devido às cargas e potências instaladas, geralmente é horo-sazonal, isto é, tem valores diferenciados para horários de ponta (três horas entre as $17 \mathrm{~h} 00$ e 22h00 nos dias úteis, definidas pela concessionária de energia local) e horários fora de ponta, o que não ocorre, por exemplo, em edifícios residenciais, cuja tarifação é convencional.

Diante destes dados, existem algumas estratégias de operação dos sistemas de ar condicionado que consideram esta diferenciação da tarifa, mas que trazem interferências em outras áreas. Por exemplo, o uso de sistemas de termoacumulação para fornecimento de água gelada nos horários em que a tarifa elétrica é mais cara e quando os equipamentos de resfriamento são desligados. Como contrapartida, estes sistemas implicam em operação e manutenção mais cuidadosas, além de demandarem espaços significativos para os reservatórios. Há, ainda, a opção de geração autônoma de energia durante o horário de pico, utilizando motores a diesel ou gás, e os requisitos de segurança e de funcionamento dos ambientes que comportam estes equipamentos devem ser observados, tais como armazenagem do combustível, tomada de ar externo, proteção contra incêndios e redutores sonoros. Qualquer que seja a escolha, ela deve levar em conta todos estes fatores, mais as implicações de espaços e de custos globais que cada sistema impõe.

\footnotetext{
${ }^{24}$ Ver também as seções 1.3.3 e 2.7 deste capítulo.
} 


\subsubsection{Sustentabilidade e arquitetura bioclimática}

Como já mencionado anteriormente, um bom projeto de ar condicionado nasce no projeto de arquitetura. Sua parcela no consumo energético dos edifícios, somada à agressividade do gás refrigerante ao meio ambiente e o ruído produzido pela instalação, torna este sistema um dos principais focos de atenção quando se fala de sustentabilidade nos edifícios de escritórios. Todas as simulações computacionais em que o desempenho energético do edifício é avaliado são unânimes ao concluir sobre a importância determinante do tipo de envoltória do edifício na variação de sua carga térmica.

Além disso, empreendimentos que desejam obter a certificação ambiental em programas específicos, tais como o $L E E D^{2}$, têm como maior desafio conquistar os pontos relacionados à eficiência energética. Para exemplificar a relevância, numa categoria C\&S (Core \& Shell), o assunto que trata deste tema (energia e atmosfera) conta com 14 pontos em 61 possíveis. Destes 14 pontos, 8 são correspondentes ao desempenho otimizado da energia, que, entre outras coisas, determina a economia de $14 \%$ de energia em relação a um modelo padrão preestabelecido (baseline da ASHRAE 90.1). O modelo padrão tem critérios já bastante restritos se comparados às edificações convencionais brasileiras, pois foi concebido para as condições climáticas norte-americanas, resultando em uma dificuldade real para se alcançar tal nível de economia apenas na otimização do sistema de ar condicionado.

Daí a importância da arquitetura bioclimática, que define elementos construtivos adequados ao clima local e que procura tirar proveito destas condições climáticas no desempenho passivo do edifício, utilizando ao mínimo os equipamentos de condicionamento artificial. Um bom exemplo deste tipo de arquitetura pode ser visto nos trabalhos de Ken Yeang, que concilia o uso intensivo de áreas nos edifícios em zonas urbanas com estratégias passivas de economia de energia. O edifício Menara Mesiniaga, construído em 1992 e localizado em Kuala Lumpur, região de clima tropical e úmido, apresenta as seguintes estratégias para um bom desempenho passivo: orientação solar adequada, átrio central espiralado utilizado como um jardim vertical, de modo a permitir a ventilação natural e melhoria da qualidade do ar interno, e venezianas (brises) externas que diminuem o ganho de calor do edifício pela envoltória (Figuras 28 e 29).

\footnotetext{
${ }^{2}$ Sigla para Leadership in Energy and Environment Design, programa para certificação descrito na seção 3 do capítulo C.
} 


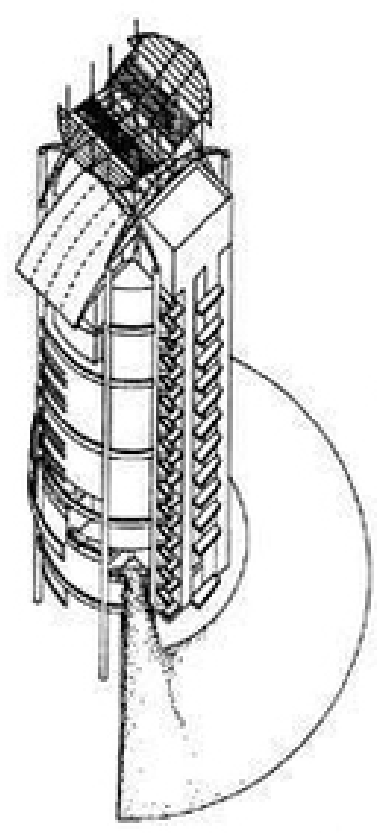

Formato da construção

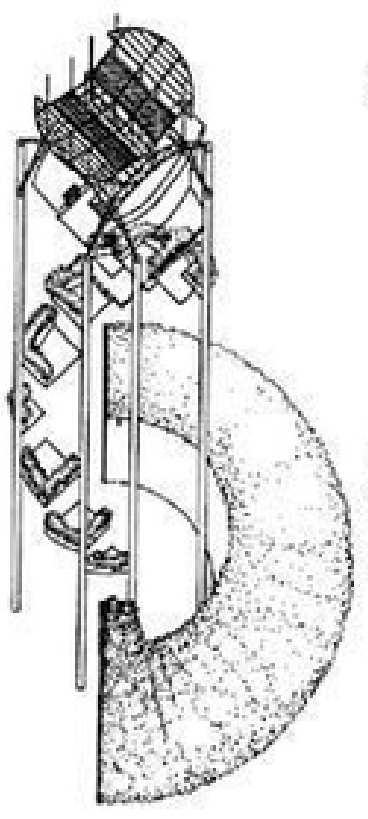

Paisagismo

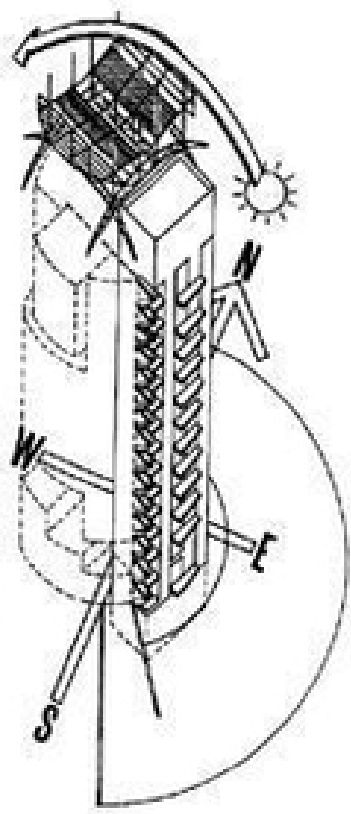

Orientação solar

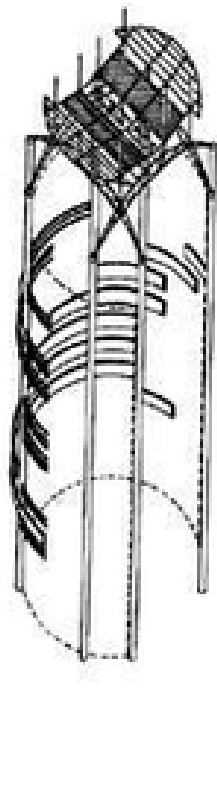

Mecanismos de sombreamento

Figura 28 - Ilustração esquemática das estratégias de desempenho passivo do edifício Menara Mesiniaga Fonte: http://jetsongreen.typepad.com/jetson_green/images/iaa0291_1.jpg

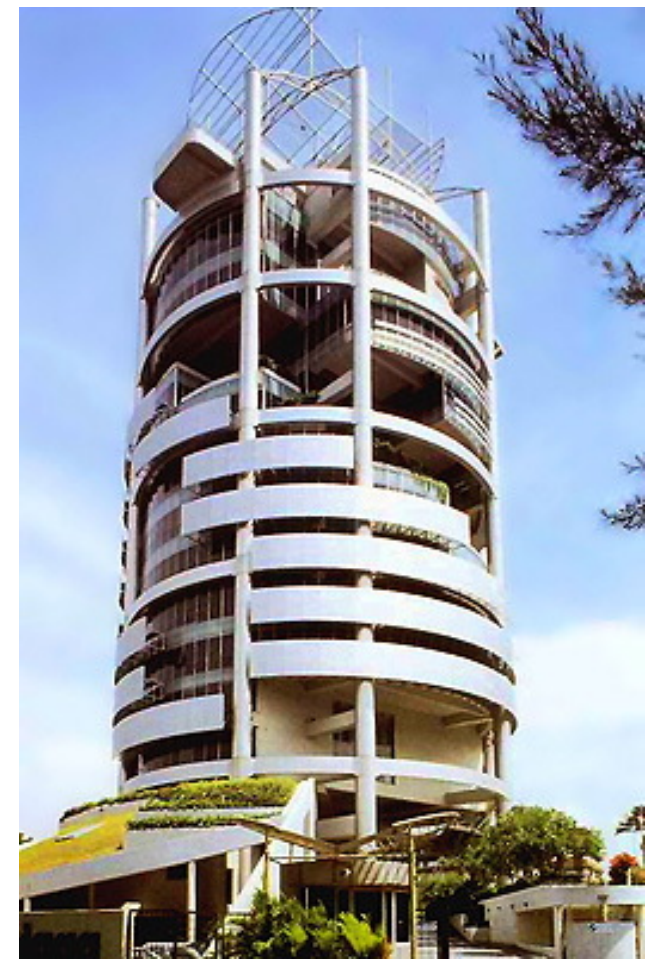

Figura 29 - Edifício Menara Mesianaga

Fonte: http://images.businessweek.com/ss/06/07/wow_green/image/2menara-mesiniaga.jpg 
Os princípios da arquitetura bioclimática também norteiam os chamados "green buildings", cujos projetos, em alguns casos extremos, introduzem elementos tais como fazendas verticais, captadores de águas pluviais, sistemas geradores de energia elétrica alimentados pela luz solar (energia fotovoltáica) e pelas forças dos ventos (energia eólica). Não há, ainda, exemplos de edifícios de escritórios com tais sistemas instalados no Brasil, pois alguns têm alto custo de implantação (o que já é uma barreira, considerando a cultura de visão de curto prazo) e outros envolvem dificuldades na segurança da operação do edifício.

Dentro deste contexto, podem ser enumeradas algumas ações possíveis para otimizar o sistema de ar condicionado e, assim, reduzir o consumo de energia associado. Estas ações podem ser divididas em ações de projeto e ações de operação e manutenção.

\section{Ações de projeto}

- Adotar partidos arquitetônicos adequados à orientação solar e que permitam a chegada de ventilação e iluminação natural às áreas centrais do pavimento. O formato do edifício também tem parcela de contribuição significativa para seu desempenho térmico;

- Para as condições climáticas brasileiras, evitar grandes áreas envidraçadas na fachada norte; se possível, protegê-las com elementos tipo venezianas externas ou brises;

- Definir fachadas com bom isolamento térmico na fachada sul;

- Prever a possibilidade do usuário controlar a abertura e fechamento de janelas para permitir o uso da ventilação natural em determinadas épocas do ano ou em algumas horas do dia;

- Reduzir a iluminação artificial desnecessária: distribuir os circuitos de modo a aproveitar a luz natural e utilizar sensores de presença para evitar áreas vazias iluminadas e condicionadas sem necessidade;

- Em halls ou lobbies com grandes alturas de pé direito, considerar a distribuição de ar refrigerado pelo piso, de modo que a temperatura de conforto esteja somente onde há pessoas, ou seja, nos primeiros dois metros de altura;

- Definir vidros com alto desempenho termodinâmico (baixos índices de transmissão e absorção térmica, coeficientes de sombra adequados);

- Adotar sistemas que permitam controle individualizado de temperatura de conforto $\left(V^{2} V^{25}\right.$ OU VRV $\left.{ }^{26}\right)$;

- Quando possível, usar a geotermia como coadjuvante no resfriamento do ar;

\footnotetext{
${ }^{25}$ Volume de ar variável.

${ }^{26}$ Volume de refrigerante variável.
} 
- Adotar sistemas de pré-tratamento do ar externo, que melhoram a eficiência do sistema;

- Adotar equipamentos energeticamente mais eficientes;

- Adotar refrigeradores (chillers) escalonados, que são acionados conforme a necessidade;

- Adotar sensores de $\mathrm{CO}_{2}$ para otimizar a renovação do ar;

- Adotar sistemas de recuperação de calor (ex: roda entálpica).

\section{Ações de operação e manutenção do sistema}

- Evitar perdas de calor e pressão em dutos e tubos, mantendo a integridade de sistemas de isolamento e desobstruindo tomadas de ar e bocas de insuflação;

- Operar eficientemente os equipamentos;

- Programar e realizar etapas de manutenção preventiva do sistema (limpeza de filtros, dutos, bocas de ar e manutenção dos equipamentos).

A manutenção preventiva é um aspecto muito importante para o bom funcionamento do sistema e, infelizmente, muitas vezes é confundida com reparos e conserto de equipamentos. Analogamente à manutenção de um carro, a manutenção preventiva do sistema de ar condicionado mantém seu funcionamento nas melhores condições possíveis a custos comparativamente mais baixos se considerados os custos de reparos.

\subsubsection{Outros sistemas mecânicos}

Além do sistema do ar condicionado, o sistema de ventilação mecânica deve ser considerado no projeto de edifício de escritórios. Suas aplicações mais comuns ocorrem na exaustão de ambientes, pressurização de escadas e exaustão de emergência.

\section{Exaustão}

Sistema de ventilação mecânica, normalmente associado à exaustão de sanitários, copas, subsolos e outros ambientes que não necessitam de condicionamento do ar, mas que necessitam de ventilação e renovação do mesmo, e não têm contato com a parede da envoltória. O sistema de exaustão é composto por ventiladores, tomadas de ar, saídas de ar e respectiva rede de dutos não isolados termicamente. Os ventiladores de exaustão dos 
sanitários e copas, por exemplo, podem ficar localizados no entreforro dos pavimentos, ou na cobertura do edifício, ligados aos pavimentos por um duto central.

\section{Pressurização de escadas}

É um sistema bastante comum em edifícios de escritórios, associado a requisitos de segurança das escadas de emergência. Seu funcionamento baseia-se no princípio de que o interior das escadas fique sempre com pressão positiva em relação ao exterior delas, de modo que, numa situação de incêndio, a fumaça originada nos andares não entre na escada de emergência, possibilitando a fuga segura da população.

O sistema é composto por ventilador, dutos e grelhas. Há requisitos especiais de segurança da sala onde fica o ventilador e de desempenho dos materiais que compõem os dutos. $A$ sala do ventilador deve ficar posicionada de forma a garantir uma tomada de ar externo, preferencialmente no pavimento de saída da edificação ou próximo a este. Ela deve ser construída de maneira a estar protegida contra fogo e fumaça por pelo menos duas horas, mesmo desempenho exigido para seus acessos e para os dutos que servem ao ventilador. O ventilador, por sua vez, deve ser alimentado por um circuito elétrico diferenciado e ligado a um gerador de emergência.

A preferência deste sistema, em relação à alternativa de uma antecâmara separadora em todos os acessos às escadas, decorre da economia de espaço, com a retirada desta antecâmara, e de custos de implantação, com a retirada de uma porta corta-fogo adicional, por acesso, às escadas.

\section{Exaustão de emergência}

A exaustão de emergência é a parte ativa do sistema de controle de fumaça, que deve ser considerada quando a ventilação natural não for suficiente para a entrada de ar limpo e a exaustão da fumaça. Geralmente atende rotas de fuga e ambientes com grandes dimensões e volumes, tais como átrios centrais e lobbies com grandes pés-direitos. O equipamento neste caso faz o contrário do sistema de pressurização de escadas: faz a exaustão do ar e da fumaça (gerando uma pressão negativa no ambiente), e somente é acionado na situação de emergência. Os requisitos de desempenho dos equipamentos deste sistema são ainda mais rigorosos do que os do sistema de pressurização, pois tanto ventiladores quanto dutos devem resistir às altas temperaturas da fumaça. 


\subsection{SISTEMAS PREDIAIS HIDRÁULICOS}

Os projetos de sistemas prediais hidráulicos tiveram, durante muito tempo, pouca notoriedade para empreendedores, arquitetos e coordenadores de projeto, quando comparados a outros projetos, como, por exemplo, os de estrutura. Isto é explicado, em parte, pela ótica da falha, que, no caso do projeto estrutural, pode resultar em perigo de morte para as pessoas (tanto as que constroem, como as que ocupam o edifício) e comprometimento total da edificação, enquanto que, no caso dos sistemas prediais hidráulicos, resulta, predominantemente, em situações apenas de desconforto, tais como falta de água, vazamentos, entupimentos e odores ruins.

Entende-se que esta situação está no início de um processo de transformação, uma vez que a preocupação com o uso racional da água e seu eventual reuso nos edifícios são temas de diversos estudos, com a crescente percepção de que este recurso será cada vez mais caro e precioso. Estes temas, aliados ao enfoque sistêmico do funcionamento do edifício, exigem uma nova forma de se abordar o projeto de sistemas prediais hidráulicos, não bastando mais apenas o atendimento da norma sobre um partido arquitetônico já concebido; a arquitetura deverá, cada vez mais, considerar este sistema em seu nascedouro.

Este capítulo trata das questões conceituais que devem ser abordadas pelo arquiteto ou empreendedor junto ao seu consultor ou projetista de sistemas prediais hidráulicos. Utilizando como referência a Tabela 4 dos Sistemas Prediais e a lógica de contratação de projeto no mercado, discorreremos sobre os seguintes sistemas e subsistemas:

- Sistema de Suprimento e Coleta de Água: sistemas de água fria, água quente, águas pluviais e esgotos sanitários;

- Sistema de Suprimento e Distribuição de Energia: sistema de gás combustível;

- Sistema de Proteção contra Incêndio: sistema de hidrantes e chuveiros automáticos.

\subsubsection{Sistema de água fria}

As recomendações para o projeto do sistema predial de água fria são regidas pela NBR 5626 (ABNT, 1998) e as regras da concessionária local. As interfaces que este sistema tem 
com o início do projeto arquitetônico resumem-se a quatro de seus subsistemas: sistema de alimentação, sistema de reservação, sistema distribuição e sistema de medição.

\subsubsection{Sistema de alimentação}

O sistema de alimentação define a fonte de fornecimento de água, que pode ser pela rede pública de água da concessionária ou por meio de fontes de águas alternativas, tais como caminhões-pipa, águas subterrâneas e águas resultantes de tratamento de efluentes e/ou águas pluviais. Estas opções devem ser consultadas junto ao órgão público responsável pelo gerenciamento de recursos hídricos local.

\subsubsection{Sistema de reservação}

O sistema de reservação implica em espaços para os reservatórios de água no edifício. Ele está relacionado com as características de oferta de água local e as características do consumo. Em São Paulo, é muito comum a utilização de dois conjuntos de reservatórios: um inferior, que recebe a água da rede pública e a recalca para um outro, superior, que distribui para os andares por gravidade. Muitas vezes este reservatório superior também contempla a reserva de incêndio. $O$ dimensionamento destes reservatórios deve ser feito pelo consultor ou projetista de sistemas prediais hidráulicos, mas cabe ao arquiteto prever os espaços necessários de forma integrada ao conjunto arquitetônico e eventualmente questionar se esta solução de dois conjuntos é realmente a melhor para seu projeto específico.

Em edifícios altos ${ }^{27}$, por exemplo, há a possibilidade de criação de um reservatório em um andar intermediário. Esta sugestão tem implicações relativas à ocupação de uma área "nobre" do edifício para um uso técnico, que pode ser discutida, especialmente se outros usos para a mesma são definidos, como, por exemplo: melhorar o desempenho de outros sistemas prediais, abrigar reservatórios para águas pluviais ou mesmo considerar esta área técnica também como área de refúgio, na necessidade de evacuação das pessoas do edifício em caso de incêndio. O contrário também é possível: em caso de restrições físicas que não permitam a utilização do reservatório superior, o projeto pode ser feito considerando somente o reservatório inferior e a distribuição realizada por meio de sistema de pressurização, desde que atendidos os requisitos de segurança que garantam o

\footnotetext{
27 Segundo Oliveira, L. H. (2008), "denominam-se edifícios altos aqueles dotados de uma altura expressiva em relação aos demais do entorno e, usualmente, apresentando formatos de torre". Para a realidade brasileira, pode-se convencionar edifícios com mais de 40 pavimentos.
} 
funcionamento dos sistemas de combate a incêndio mesmo com falha de fornecimento de energia por parte da rede pública local.
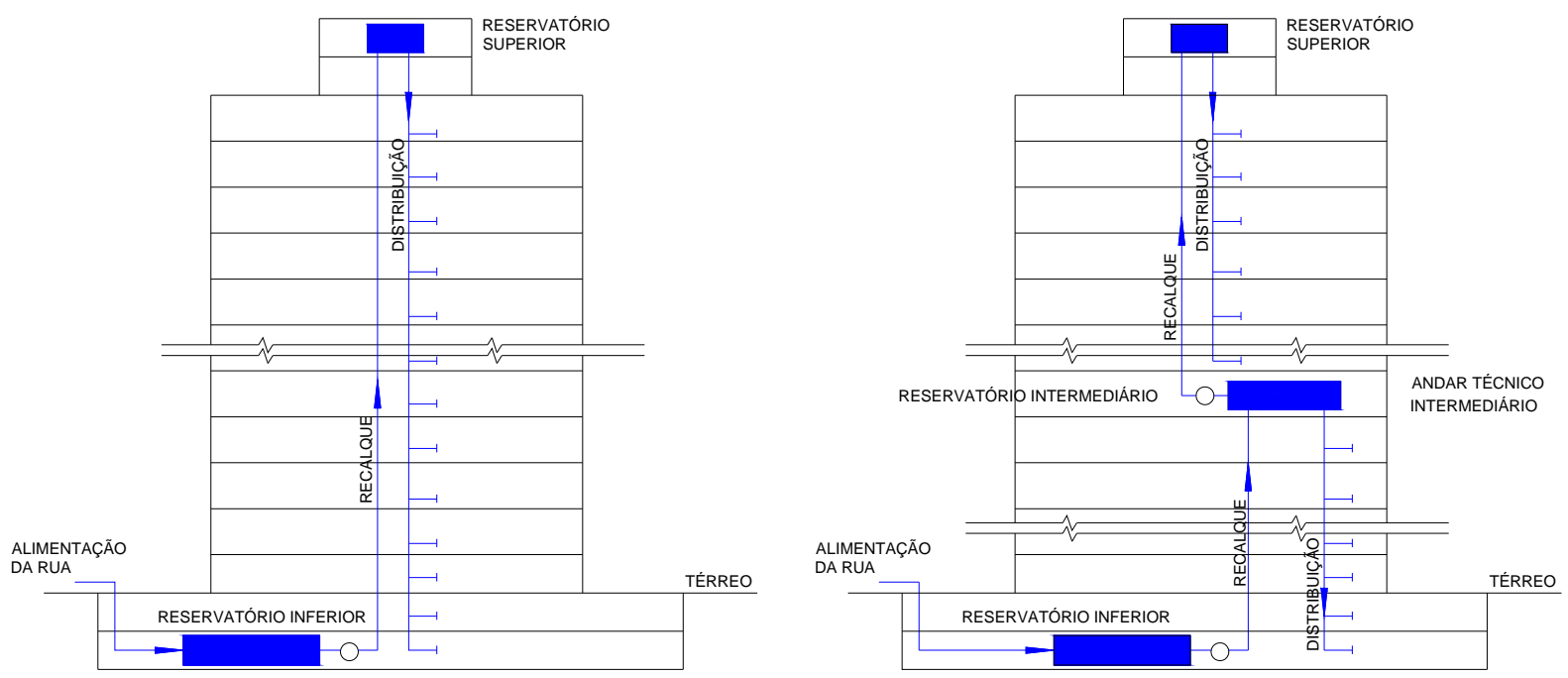

À esquerda, esquema tradicional de reservatório inferior e superior. À direita, exemplo de utilização de reservatório intermediário.

O recurso do reservatório em andar intermediário é preferencialmente utilizado em edifícios muito altos (em torno de 100 pavimentos) e, entre outras funções, auxilia no efeito de redução de pressão da água nos andares mais baixos

Figura 30 - Desenhos indicando esquemas de reservação de água fria

\subsubsection{Sistema de distribuição}

O sistema de distribuição tem menor influência em espaço no projeto arquitetônico, se comparado ao sistema de reservação, mas existe e deve ser considerado. As tubulações verticais, tanto de recalque quanto de distribuição por gravidade, devem ser locadas de tal forma a minimizar os percursos horizontais e a permitir visita para inspeção e manutenção. Uma maneira de otimizar os espaços requisitados por estas tubulações é pelo seu agrupamento em dutos verticais (shafts) visitáveis.

Outro aspecto relacionado ao sistema de distribuição refere-se ao próprio ponto de consumo. A responsabilidade pela especificação do aparelho sanitário é do arquiteto ou do projetista dos sistemas prediais, mas, muitas vezes, o empreendedor e o construtor acabam optando por alternativas durante a execução da obra. Antes de se adotar um determinado modelo ou marca, o arquiteto ou projetista deve verificar os requisitos de desempenho dos aparelhos, principalmente consumo reduzido de água, e assim fazer a especificação. 
Torneiras hidromecânicas e eletrônicas, arejadores, válvulas de descarga e caixas de descarga com duplo acionamento são exemplos de aparelhos sanitários disponíveis no mercado e que contribuem para o uso racional da água.

\subsubsection{Sistema de medição}

O sistema de medição influencia diretamente na maneira como o edifício será operado e, indiretamente, no regime de consumo de água. Ele pode contar com um medidor único, cujo total medido é rateado entre as unidades autônomas, ou contar com um sistema individualizado, em que cada unidade tem seu medidor próprio. Experiências em edifícios residenciais, que realizam a mudança do sistema de medição de único para o individualizado, apresentam reduções significativas de consumo, e o mesmo raciocínio pode valer para os edifícios de escritórios.

Apesar disso, muitos edifícios de escritório de andar livre, mesmo os de alta classificação mercadológica, não contam com sistema individualizado, exceto para a medição de consumo de água gelada do ar condicionado, quando o mesmo apresenta este subsistema hidráulico.

\subsubsection{Outros aspectos}

Os aspectos da operação e manutenção também devem estar previstos em projeto. Em andares de escritório onde não há previsão de depósito de material de limpeza com torneira ou tanque, deve-se prever, em algum sanitário, a existência de uma torneira com altura compatível para uso pela equipe de limpeza, para evitar uma prática muito comum, que é a retirada do sifão do lavatório para enchimento de baldes.

\section{Estratégias de uso da água}

Há duas estratégias importantes sobre o uso da água que merecem atenção nos projetos de sistemas prediais hidráulicos dos edifícios: conservação e uso racional da água (Figura 31). A primeira estratégia consiste em equacionar o uso da água em duas frentes: na oferta e na demanda, enquanto a segunda promove basicamente o controle da demanda. 


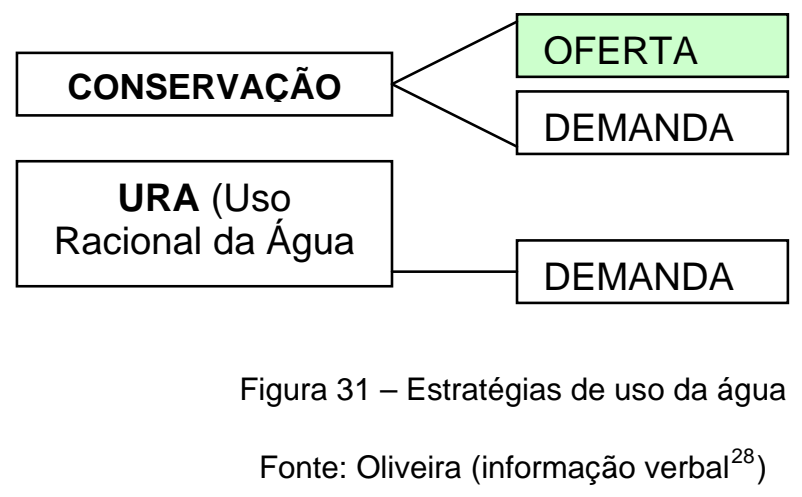

A oferta de água refere-se à fonte de abastecimento do edifício. Como mencionado no sistema de alimentação, este abastecimento pode ser o da rede pública local ou vir de fontes de água alternativas. O incremento do uso de águas alternativas aumenta a oferta de água no edifício sem sobrecarregar o sistema de abastecimento da rede pública, e algumas maneiras de obtê-las serão tratadas nos itens referentes a águas pluviais e esgotos sanitários. Além disso, é necessário fazer o correto gerenciamento do uso da água destas fontes, devido à inconsistência do seu nível de potabilidade.

A demanda de água refere-se ao consumo propriamente dito no edifício. Segundo Schmidt (2003), um programa de uso racional da água "consiste da aplicação de determinadas ações em uma edificação, com o objetivo de se reduzir seu consumo de água, garantindo-se a qualidade das atividades consumidoras". Em algumas metodologias de implantação deste tipo de programa (TESIS, 1988 apud SCHMIDT, 2003, e OLIVEIRA, L. H., 1999), pode-se mencionar o uso de dispositivos para o controle do consumo, tais como: a correta especificação de equipamentos economizadores; a medição individualizada; a manutenção preventiva das instalações para evitar perdas no sistema e, principalmente, a conscientização dos usuários.

A conscientização dos usuários é especialmente importante na estratégia da conservação, pois o aumento da oferta de água pode ocasionar um entendimento equivocado de que não há mais a necessidade de ações para a redução da demanda. A estratégia da conservação só faz sentido se o equacionamento do uso da água for realmente feito nestas duas frentes.

\footnotetext{
${ }^{28}$ Informação obtida junto a prof. Lúcia Helena Oliveira, em 05 mar. 2009.
} 


\subsubsection{Sistema de água quente e gás combustível}

As recomendações para o projeto da instalação predial de água quente são regidas pela norma NBR 7198 (ABNT, 1992), e as de gás, pela norma NBR 15526 (ABNT, 2009). Em edifícios de escritório no Brasil, a água quente é um item de pouca relevância, pois seu uso fica restrito a alimentação de chuveiros de sanitários coletivos, normalmente localizados no embasamento $^{29}$ do edifício, e seu consumo é reduzido, se comparado ao consumo total de água da edificação. A água quente não é considerada para alimentar os lavatórios mesmo em empreendimentos luxuosos e com alta classificação mercadológica, denotando que este uso não tem valor percebido junto aos empreendedores deste tipo de edifício.

O gás, por sua vez, tem uso mais relevante se o edifício em questão abrigar, em sua área de amenidades, restaurantes ou refeitório central, pois as copas dos andares tipo têm sido projetadas, cada vez mais, para receber equipamentos elétricos. Há, também, muitos empreendimentos que prevêem a alimentação dos sanitários coletivos do embasamento com chuveiros elétricos. Em empreendimentos complexos, muito grandes ou de múltiplos usos, pode-se utilizar o gás como fonte alternativa de energia, gerando eletricidade por meio de sua queima, e aproveitar o calor resultante do processo original para outros fins, tais como aquecimento de água, geração de vapor e até resfriamento de ambientes. Este aproveitamento do calor, que normalmente seria perdido no processo de geração de energia, denota a chamada co-geração.

De qualquer forma, havendo previsão para o uso do gás na edificação, há recomendações especiais de segurança quanto à localização da central de alimentação e à tubulação de distribuição, que devem ser de conhecimento do projetista destes sistemas e do arquiteto.

\subsubsection{Sistema de água pluvial}

As recomendações para o projeto do sistema de água pluvial são regidas pela norma NBR 10844 (ABNT, 1989), que traz os critérios para seu dimensionamento, a tabela com as intensidades pluviométricas, de acordo com o local e o período de retorno, e critérios para o cálculo de área de contribuição. Neste último item, é interessante observar que as fachadas dos edifícios também entram neste cálculo, e podem até ser consideradas como áreas de contribuição dominantes, principalmente no caso de edifícios altos.

\footnotetext{
${ }^{29}$ Térreo e subsolos.
} 
O conceito que trata do fluxo de captação, condução e afastamento das águas pluviais está sendo substituído pelo de captação, tratamento, reserva e uso destas águas no edifício. Esta mudança decorre de diversos fatores, alguns dos quais podemos enumerar: crescimento da consciência ecológica, encarecimento dos custos de fornecimento de água, adoção de princípios de sustentabilidade no projeto do edifício, interesses em obter pontuação em sistemas de certificação ${ }^{30}$ ambiental e possibilidade de redução de custos de operação.

A utilização de águas pluviais tratadas no edifício muitas vezes é erroneamente chamada de reuso. O reuso, como o próprio nome indica, caracteriza-se por uma repetição de uso, o que significa o aproveitamento de uma água que já foi utilizada em algum consumo anterior. A água pluvial, por sua vez, pode ser considerada como uma fonte alternativa de abastecimento.

O nível de tratamento que a água pluvial deve receber depende da destinação que terá a água tratada. Quanto maior o nível de potabilidade da água que se deseja atingir, mais caro é o sistema e a operação de tratamento, e maior a responsabilidade do operador do edifício sobre a qualidade e uso desta água. Como grande parte dos empreendedores brasileiros não faz a operação do edifício que concebem, as soluções preferenciais remetem aos tratamentos de investimento menor, mais simples, preferencialmente passivos, que permitem uma qualidade de água suficiente para irrigação de jardins, lavagem de pisos e uso em bacias sanitárias.

A utilização bem-sucedida da água pluvial tratada depende principalmente de uma administração predial preparada para isso, uma vez que esta será responsável pela qualidade do tratamento ao longo do tempo e pelo correto controle de acesso a torneiras ou registros que disponibilizarão esta água. O preparo diferenciado de uma administração predial de edifício de escritórios em relação a um edifício residencial explica em parte a maior adesão, no primeiro caso, deste sistema.

Atualmente, nos projetos de edifícios de escritório de São Paulo, o conceito mais comum para utilização da água pluvial tratada consiste em sua captação, condução total até um reservatório inferior (geralmente localizado no subsolo), tratamento, recalque até um reservatório superior e distribuição (Figura 32). Este modelo segue a lógica do conceito de distribuição de água fria; além disso, ele pode aproveitar a obrigatoriedade do tanque de retenção de água pluviais (Lei 13.276/02 do Município de São Paulo) previsto em projetos de edifícios novos com mais de $500 \mathrm{~m}^{2}$ de área impermeabilizada. Por este modelo, as implicações no projeto arquitetônico aparecem na forma de espaços extras para

\footnotetext{
${ }^{30}$ Ver seção 3 do capítulo C.
} 
reservatórios, tubulações e casa de bombas, pois a água pluvial tratada deve estar em um sistema completamente independente da água fria, para evitar o fenômeno da conexão cruzada (NBR 5626, ABNT, 1998).

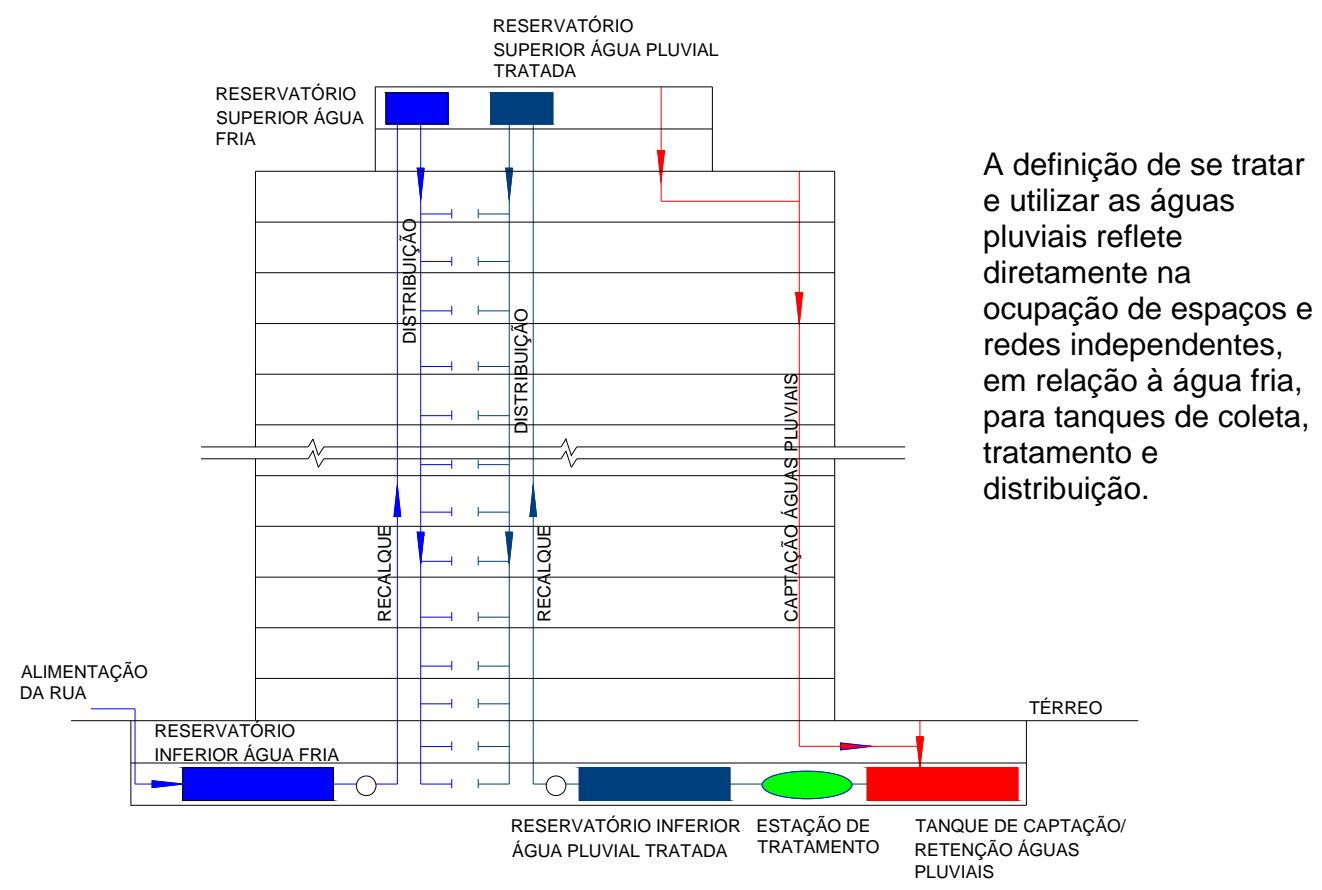

Figura 32 - Desenho esquemático de reservação de água fria e de aproveitamento das águas pluviais

Em países onde o custo da energia elétrica é maior do que no Brasil, como os do norte da Europa e os dos Estados Unidos, o conceito para o uso das águas pluviais e de reuso das águas servidas ${ }^{31}$ é um pouco mais complexo. Primeiramente, há um equacionamento da energia que é gasta para o funcionamento do sistema com o nível de potabilidade de água que se deseja alcançar, além da qualidade final do ar que resulta deste gasto de energia. $O$ Pacific Institute (Califórnia, EUA), por exemplo, disponibiliza um simulador que analisa, entre outras coisas, a energia consumida para fazer que a água, seja ela de rede pública, seja de fonte alternativa, chegue ao seu destino final, o que possibilita a tomada de decisões a respeito de sua gestão. Este simulador pode ser alimentado de forma que diversos cenários possam ser comparados. Com estas informações, em conjunto com a arquitetura, os sistemas de abastecimento e aproveitamento das águas são definidos. Esta necessidade da estreita interação entre arquitetura e sistemas prediais, nas etapas iniciais de um projeto, pode ser bem exemplificada no projeto do Water Town (Chicago, EUA), em que a água pluvial é captada, tratada e reservada de forma escalonada (Figuras 33 e 34) com uso mínimo de energia. A captação da fachada deve estar integrada a este escalonamento, e os reservatórios intermediários, previstos desde a concepção do projeto.

\footnotetext{
${ }^{31}$ Esgotos sanitários.
} 

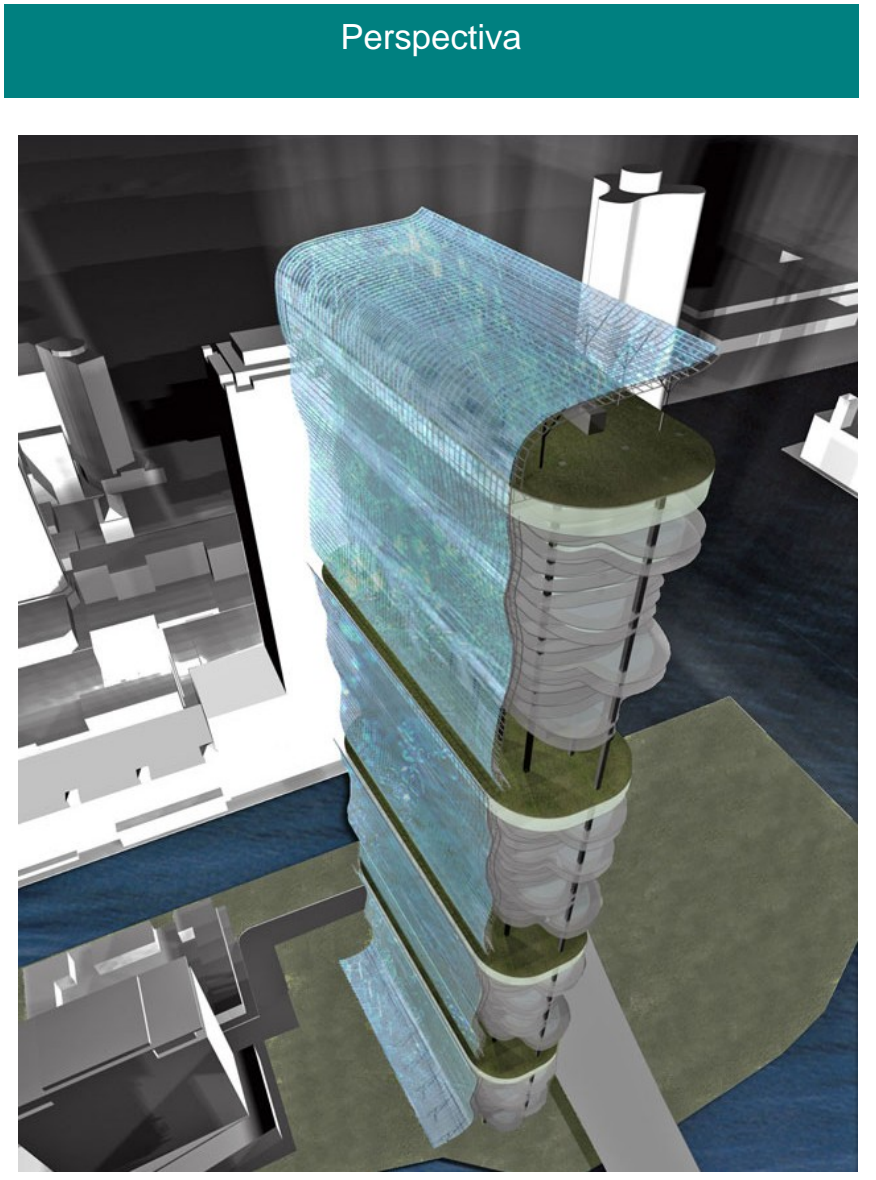

Figura 33 - Projeto do edifício Water Town, Chicago (EUA)

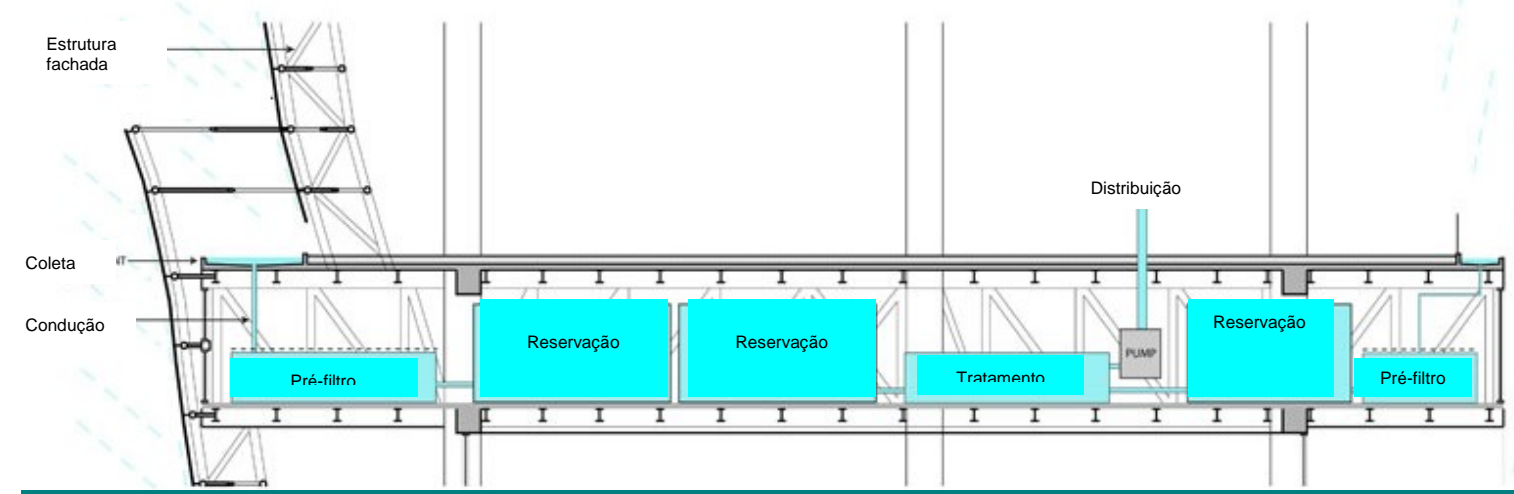

Desenho esquematizado do sistema de captação, tratamento e reservação de águas pluviais

Figura 34 - Detalhe do projeto do edifício Water Town, Chicago (EUA)

Fonte: www.ctbuh.org/Portals/O/Education/IIT/AntonyWood/Tall\&Green/WaterTower. 


\subsubsection{Sistema de esgoto sanitário}

As recomendações para o projeto de sistemas de esgotos sanitários são regidas pela norma NBR 8160 (ABNT, 1999). O objetivo desta norma é estabelecer as exigências e recomendações para atendimento dos requisitos mínimos de higiene, segurança e conforto dos usuários.

\section{Sistemas}

Assim como ocorre com o sistema de água pluvial, o impacto do sistema de esgoto sanitário no projeto arquitetônico é aparentemente pequeno, desde que mantidos os devidos cuidados para espaços para as tubulações de caminhamento horizontal (ramais e coletores) e de caminhamento vertical (tubos de queda e colunas de ventilação). A maioria dos projetos brasileiros considera o escoamento do esgoto por conduto livre (gravidade), portanto é importante garantir, nos percursos horizontais, espaços que permitam a declividade mínima exigida nas tubulações deste sistema.

Existem também sistemas de coleta e transporte de esgoto a vácuo que ganham espaço devido ao seu forte apelo por economia de água. A opção por este sistema permite utilização de diâmetros menores de tubulação e percursos horizontais praticamente sem declividade, devido ao seu regime de subpressão. As desvantagens deste sistema envolvem, além do aspecto cultural, previsão de espaços para colocação de bombas de vácuo e tanques, além de gastos com energia para sua operação e manutenção mais complexa.

Ainda sob o ponto de vista da economia de água, há também aparelhos que dispensam o uso desta tanto para seu acionamento quanto para seu desconector ${ }^{32}$, tais como os mictórios sem água (Figura 35). Neste caso, não há acionamento de água para descarga da urina, e um selo líquido, cuja densidade é menor do que a da urina, faz a função do fecho hídrico. A manutenção deste tipo de aparelho pede apenas a troca deste líquido em um número de usos que pode variar de acordo com o fabricante do selo. Como exemplo, a fabricante Waterless sugere esta troca a cada 1.500 usos sanitários. Este tipo de aparelho representa uma relevante solução para a economia de água em edifícios de escritórios, pois, segundo Schmidt (2003), "o mictório é um exemplo de equipamento que historicamente representa um desperdício significativo de água", mas alguns aspectos dificultam sua efetiva introdução nos ambientes brasileiros: a falta de fabricantes nacionais,

\footnotetext{
${ }^{32}$ Ver definição na seção Desconectores, abaixo.
} 
a questão cultural e a segurança do sistema. A questão cultural tem a ver com o correto uso (não há acionamentos) e manutenção (o aparelho não deve ser limpo com água, somente com pano úmido); a questão da segurança envolve eventual toxicidade, em longo prazo, da evaporação do líquido no ambiente e do seu descarte após o ciclo de usos. Schmidt (2003), em seu estudo sobre mictórios sem água, conclui que a eliminação da água do processo de coleta de urina não afeta negativamente o desempenho do ambiente sanitário.

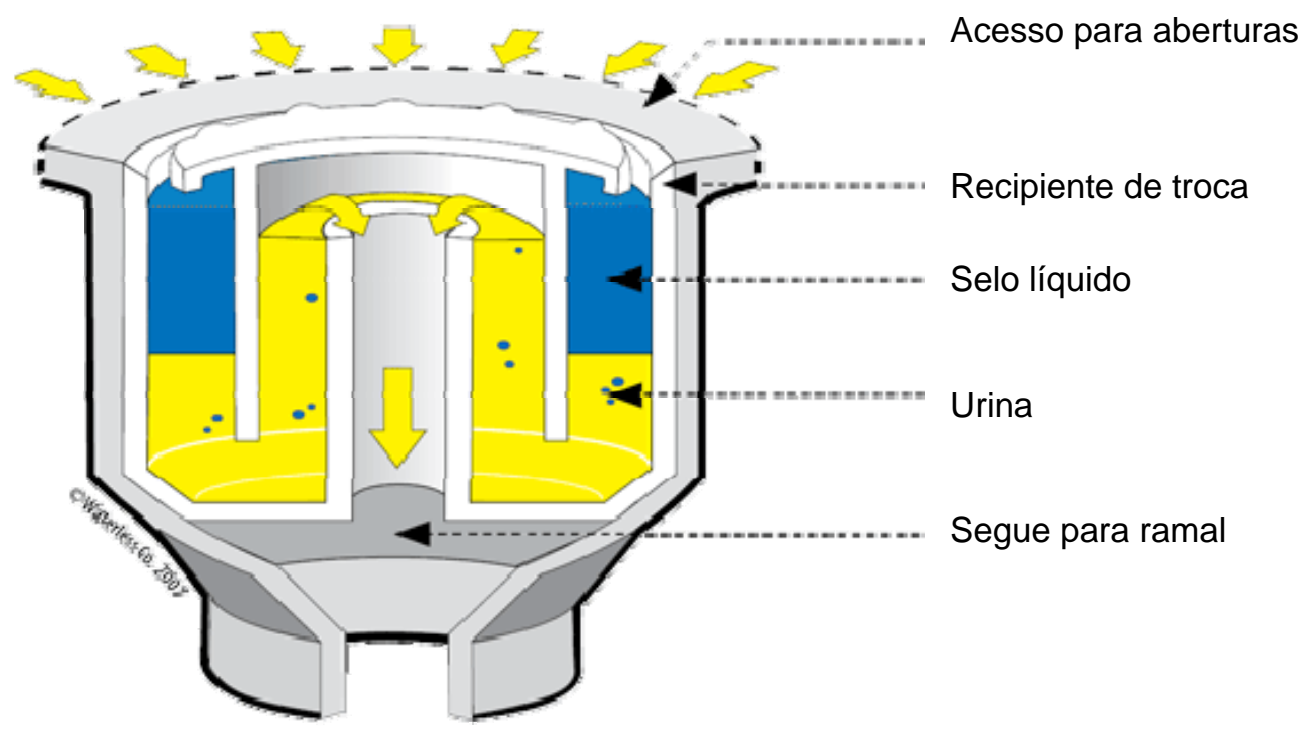

Figura 35 - Exemplo de desconector do mictório seco

Fonte: waterless.com/index.php?option=com_content\&task=view\&id=3\&ltemid=55

\section{Desconectores}

Outro aspecto importante a ser considerado no sistema de esgoto refere-se ao desconector, que, segundo definição da NBR 8160 (ABNT, 1999), é um "dispositivo provido de fecho hídrico, destinado a vedar a passagem de gases no sentido oposto ao deslocamento do esgoto". Na prática, os desconectores são basicamente os sifões dos diversos aparelhos sanitários e de alguns tipos de ralos. Graça (1985) estudou alguns efeitos que podem comprometer o bloqueio hídrico destes sifões, e que podem ocorrer em edifícios de escritório:

\section{- Evaporação}

Decorrente de condições climáticas (temperatura e umidade relativa do ar), condições geométricas (tipo de sifão e distância do mesmo até o tubo de queda) e tempo de 
exposição sem escoamento de esgoto. Pode ocorrer em sanitários que ficam muito tempo sem utilização, por exemplo, em escritórios não ocupados, aguardando locador.

- Variação de pressão do ambiente

Sanitários de edifícios de escritórios normalmente ficam localizados em seu núcleo e contam com exaustão mecânica, o que gera uma pressão ambiente menor que a pressão atmosférica. No caso de sanitários integrados à área útil ${ }^{33}$, o ar condicionado cria o efeito contrário: pressão ambiente maior que a pressão atmosférica. Ambos os casos modificam as alturas do nível d'água da câmara de entrada e da câmara de saída do fecho hídrico.

- Sifonagem induzida

Situação em que o escoamento de um aparelho sanitário influi no fecho hídrico de outro aparelho inoperante próximo, ligado ao mesmo ramal de esgoto, como é o caso dos aparelhos em bateria dos sanitários coletivos.

Ainda há outros efeitos, tais como capilaridade, tiragem térmica, efeito do vento e sobrepressão, que também devem ser considerados no dimensionamento e especificação do desconector.

A importância dos desconectores, apesar da aparente pouca significância no projeto como um todo, ganha outra dimensão em casos extremos de falha: Swaffield (2006) sugere uma ligação direta entre o início da epidemia da SARS ${ }^{34}$ de 2003, no condomínio Amoy Gardens, em Hong Kong, com o rompimento dos fechos hídricos dos sanitários e a conseqüente contaminação do ar. A origem do rompimento seria a combinação entre falta de manutenção do sistema, permitindo o efeito da evaporação, combinada ao uso de exaustores para ventilação, o que teria criado uma pressão negativa nos sanitários e permitido a disseminação inicial do vírus entre andares.

\section{Reuso}

O aproveitamento do esgoto por meio de seu tratamento é um tema em voga, decorrente, em parte, do apelo mercadológico, da redução dos custos referentes a consumo de água e da conquista de pontos em processos de certificação de edifícios verdes.

As variáveis para definição do sistema a ser considerado no projeto consistem em: o volume necessário, o que vai ser tratado (se todo o esgoto sanitário ou se somente as águas

\footnotetext{
${ }^{33}$ Ver item 1.2.1.2 deste capítulo.

${ }^{34}$ Síndrome da deficiência respiratória severa.
} 
$\operatorname{cinzas}^{35}$ ), o destino final que será dado à água tratada (que definirá seu nível de potabilidade e complexidade de tratamento), os custos (tanto de implantação quanto de operação) e as demandas técnicas e de espaços de cada sistema. Como já anteriormente comentado no item do sistema de água pluvial, a operação de tratamento de água (seja pluvial ou esgoto) tem um gasto energético que deve ser compensado pela economia de água, ou deixa de ser viável no empreendimento.

A prática mais comum em edifícios de escritórios em São Paulo é fazer o tratamento das águas cinzas e utilizá-las para descargas das bacias sanitárias. O modelo é parecido com o tratamento de águas pluviais, em que as águas cinzas são coletadas e tratadas em um reservatório inferior, e, em seguida, recalcadas para um reservatório superior, para posterior distribuição. Algumas empresas já se especializaram em fazer esta operação (fornecem os equipamentos para tratamento e fazem a gestão do sistema) e a comercializam por meio do valor do metro cúbico de água tratada (que deve ser inferior ao valor da água potável fornecida pela rede pública). Assim, a gestão do uso de água de reuso passa a ser mais um serviço a ser contratado pela administração predial.

Algumas questões ainda devem ser definidas junto ao empreendedor e projetista, tais como: a integração deste sistema ou não ao de tratamento de águas pluviais; o controle de acesso à água de reuso; como o sistema será alimentado pelo sistema de água fria, caso a demanda seja maior do que a oferta, e como será evitado o fenômeno da conexão cruzada entre sistemas (água potável e água de reuso). O cálculo do volume de água a ser tratado, devidamente equacionado com a demanda esperada, evita desperdício de energia para o processo de tratamento e condução das águas, e o desperdício de espaços demandados pelo sistema de tratamento.

\subsubsection{Sistema de proteção contra incêndio}

O sistema de proteção contra incêndio compõe-se de diversos outros subsistemas ${ }^{36}$ e os mencionados neste item são diretamente relacionados com sistemas prediais hidráulicos. As recomendações para o projeto deste sistema estão em diversas normas da ABNT que integram o decreto estadual $n^{\circ}$ 46076/01 do Corpo de Bombeiros do Estado de São Paulo e suas respectivas Instruções Técnicas (IT). Muitos empreendedores também consideram os

\footnotetext{
${ }^{35}$ Águas servidas de lavatórios e chuveiros.

${ }^{36}$ Ver seção 3.5 deste capítulo.
} 
requisitos da norte-americana NFPA (National Fire Protection Association), motivados por questões de seguro e, em outros casos, pela origem internacional dos investimentos.

Os aspectos da proteção contra incêndio, relacionados aos sistemas prediais hidráulicos, estão inseridos nas medidas de proteção ativa dos sistemas de segurança, que são as medidas de combate ao fogo. Entre elas, podemos destacar:

\section{Reserva de incêndio}

A reserva de incêndio é calculada de acordo com a área construída, o uso do edifício (tipifica também o grau de risco) e o tipo de hidrante ou mangotinho. Para exemplificar, um edifício de escritórios de $10.000 \mathrm{~m}^{2}$ de área construída terá uma reserva de incêndio de 12 a $18 \mathrm{~m}^{3}$. Como já descrito anteriormente, a integração da reserva de incêndio com a de água fria é uma prática comum, e normalmente ela é disposta no reservatório superior da edificação, o que influencia diretamente nas sobrecargas da estrutura.

\section{Sistema de hidrantes}

Os pontos de água deste sistema devem servir a todos os andares, o que requer previsão de espaço na arquitetura para tal. Além disso, estes pontos também são determinados em função do comprimento e alcance da mangueira, podendo ocasionar a presença de mais de um ponto por andar.

\section{Sistema de chuveiros automáticos (sprinklers)}

Integrantes de um sistema de combate ao fogo bastante eficaz, os chuveiros automáticos são ligados a algum tipo de sistema de detecção, obrigatórios em grande parte das configurações de edifícios de escritório e integrantes dos diversos sistemas que ocupam o espaço situado entre a laje e o forro do andar. O critério de dimensionamento deste sistema é regido pela Instrução Técnica no 23 do decreto 46.076/01 e pela NBR 10897 (ABNT, 2007). O impacto deste sistema na arquitetura configura-se no espaço para o sistema de reservação de água e a compatibilização da distribuição de seus chuveiros com os outros diversos sistemas que ocorrem no forro, tais como luminárias, grelhas do ar condicionado e sistemas de detecção. 


\subsection{SISTEMAS PREDIAIS ELÉTRICOS}

Os sistemas prediais elétricos, que sempre tiveram grande importância por serem associados ao funcionamento dos sistemas ativos dos edifícios e por serem também considerados fontes possíveis de ignição de incêndios, ganham ainda mais destaque por sua contribuição direta para a sustentabilidade do edifício, preocupação decorrente do aumento progressivo dos custos da energia e consequentes custos de operação.

A rápida evolução da tecnologia dos diversos sistemas e o aumento da dependência de energia para seu bom funcionamento faz que os edifícios de escritórios modernos exijam instalações de infra-estrutura elétrica mais complexas. De Martini (2008) comenta que os edifícios comerciais corporativos "possuem hoje requerimentos rigorosos em energia, capacidade, disponibilidade e confiabilidade, telecomunicações sempre em constante evolução, segurança e proteção, qualidade ambiental e de forma muito atual, compromissos com políticas ambientais e de sustentabilidade".

As principais diretrizes para um bom projeto de instalações elétricas seguem os mesmos preceitos dos sistemas prediais como um todo ${ }^{37}$, incluindo os seguintes objetivos abaixo, segundo De Martini (2008):

- Desenvolver o projeto com as soluções mais atualizadas;

- Preparar o sistema para evoluir com o passar do tempo, levando em conta a vida útil do edifício (cerca de 20 a 30 anos, ou até mais);

- Projetar sistemas simples e confiáveis;

- Considerar equacionamento entre custo inicial (de implantação) e custo global (de toda a vida útil) dos sistemas.

A preparação para evolução do sistema conta também com os requisitos de espaços, ou seja, a arquitetura também deve ser pensada quando o aspecto da adaptação e modernização do sistema é considerado.

Em termos gerais, os sistemas prediais elétricos exercem pequena influência na demanda de espaços do pavimento tipo durante a concepção do projeto arquitetônico, se comparados aos sistemas de ar condicionado. Nesta etapa inicial de projeto, sua influência é percebida na implantação do edifício no terreno e, em etapas posteriores de detalhamento, é definitiva na eficiência da operação do edifício.

\footnotetext{
${ }^{37}$ Ver seção 3.1 deste capítulo.
} 
Para fins deste trabalho, que investiga os requisitos técnicos das etapas iniciais do projeto de edifício de escritórios, os aspectos mais relevantes referentes aos sistemas prediais elétricos concentram-se nos itens que apresentam alguma interferência física para as demais disciplinas de projeto, notadamente arquitetura e estrutura.

\subsubsection{Normas}

As recomendações para projeto de instalações elétricas nos edifícios são regidas pelas normas NBR 5410 (ABNT, 2004), para baixa tensão, e NBR14039 (ABNT, 2005), para média tensão, prerrogativas da ANEEL (Agência Nacional de Energia Elétrica), além de regras da concessionária de energia local.

\subsubsection{Entrada e medição de energia}

A configuração e implantação no edifício no terreno têm influência na definição do local para a entrada e medição da energia, pois as distâncias entre o poste da concessionária (localizado na rua) e os medidores do edifício determinam o volume de cobre a ser consumido no trecho da chamada "corrente não medida", o que gera impacto direto no custo da instalação. Segundo Loturco (2008), os critérios deste trecho são definidos pela concessionária local e, em termos nacionais, não são uniformes.

Por esta e por outras razões, há, no início do projeto de instalações elétricas, uma forte interação entre o projetista ou consultor destas instalações e a concessionária local, seja para verificar a viabilidade de fornecimento de energia na demanda necessária, seja para negociar a flexibilização de algumas regras no caso de concepções não convencionais.

Em termos gerais, o projetista ou consultor de instalações elétricas faz o cálculo de demanda de energia do edifício e avalia, de acordo com a sua forma de funcionamento (se com vários proprietários, ou com um só e vários inquilinos) e com as regras da concessionária, as possibilidades de fornecimento de energia: em alta, média ou baixa tensão ${ }^{38}$. Ele também avalia qual a melhor modalidade de tarifação para aquele edifício

\footnotetext{
38 Alta tensão: tensão do sistema de transmissão (69 ou 138kV).

Média tensão: tensão primária de distribuição (13,8 ou 25kV).

Baixa tensão: tensão secundária de distribuição (220, 380, 440, 480V).
} 
especificamente. Todos estes critérios influenciarão nos espaços a serem ocupados por salas técnicas de medição, subestações ou transformadores, além da quantidade, tipo e custo dos cabos.

Ainda na concepção do projeto, também é conveniente já estar definido como será feita a medição individualizada das áreas de escritório e comuns, e dos grandes centros de consumo de energia, tais como elevadores e centrais de ar condicionado. Os equipamentos de medição geralmente necessitam de um painel que pode ser considerado para cada unidade. De Martini (2008) destaca que o fornecimento em uma única medição, possibilidade para edifícios de um único proprietário e unidades para locação, permite o fornecimento de energia em média tensão, trazendo as seguintes vantagens:

- Flexibilidade em relação à demanda máxima esperada, e seus eventuais acréscimos,

- Flexibilidade da instalação interna relacionada às posições das subestações e do sistema de distribuição.

Loturco (2008) acrescenta outra vantagem do fornecimento em média tensão, em relação à baixa tensão, que é o custo de instalação, ao reduzir o volume de cobre dos cabos de entrada.

\subsubsection{Distribuição de energia}

A distribuição de energia é feita, entre andares, por meio de prumadas, que podem ser compostas por conjuntos de cabos ou por barramento blindado (Figura 36). Em cada andar deve haver o acesso restrito a esta prumada, para fins de manutenção, que pode consistir numa pequena sala ou em um armário protegido no seu núcleo. Desta prumada, saem os cabos para os quadros de distribuição e, destes quadros, os circuitos elétricos que alimentam os diversos equipamentos do andar, tais como: luminárias, reatores, tomadas, sistemas de controle, etc. A distribuição dos circuitos é feita principalmente pelo forro (para os sistemas de iluminação e de detecção) e pelo piso (tomadas), considerando a formatação do andar tipo de planta livre.

Convém lembrar que as prumadas de distribuição devem possuir seccionadores entre os andares, com material resistente ao fogo, de maneira a impedir a propagação de fogo e fumaça, em caso de situações de incêndio, pelo efeito chaminé. Estes seccionadores são conhecidos no mercado como fire-stops. 

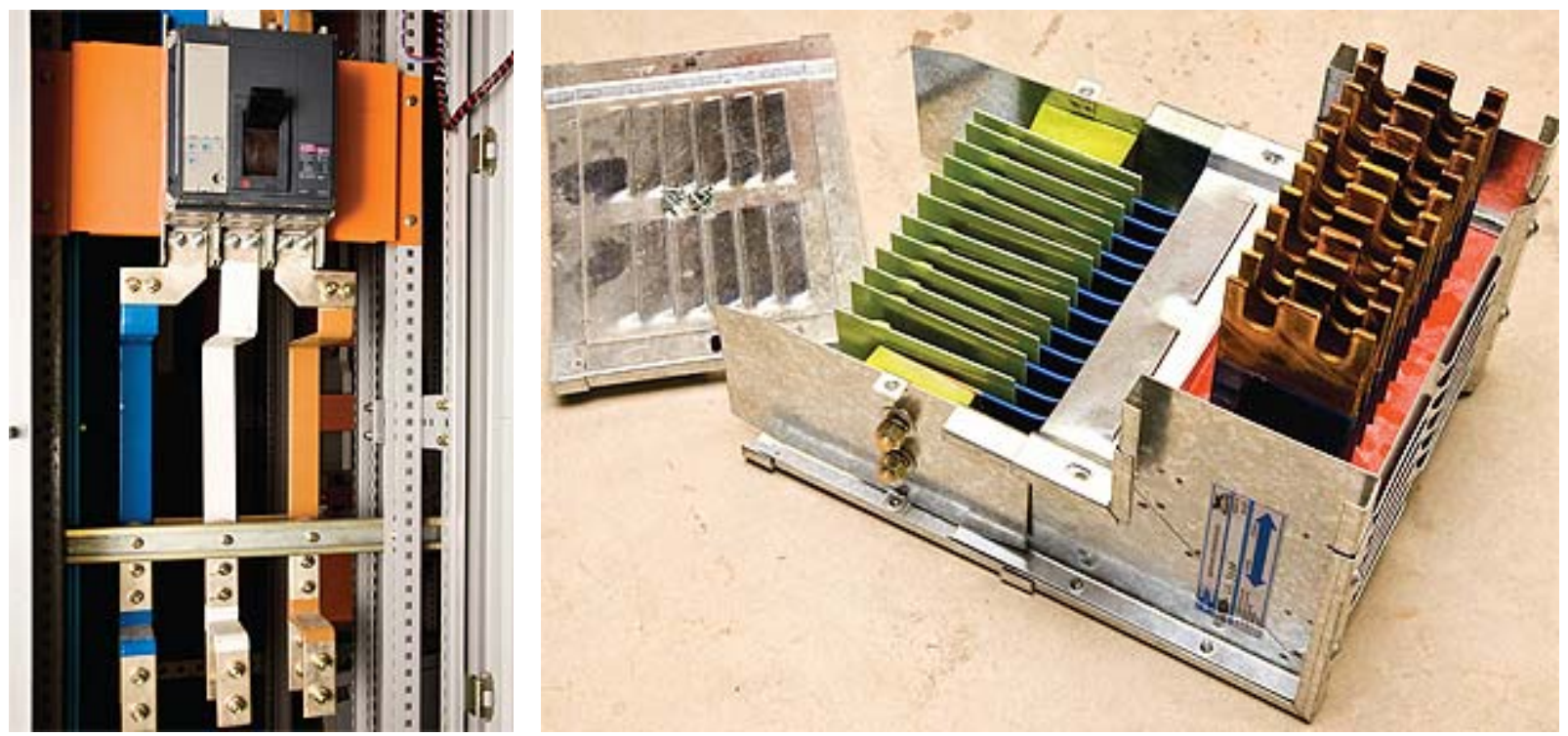

Figura 36 - Barramento blindado

Fonte: Loturco (2008)

\subsubsection{Premissas para iluminação e tomadas}

A iluminação interna do edifício tem importante contribuição no seu desempenho energético e na produtividade de seus usuários. O desempenho energético está diretamente ligado ao consumo de energia e emissão de calor das lâmpadas e reatores, pois a iluminação artificial é responsável pelo consumo de cerca de 12 a 15\% da energia do edifício (informação verbal $^{39}$ ). A produtividade dos usuários está relacionada ao conforto visual que esta iluminação traz em longos períodos de tempo, o que ressalta a importância do desenvolvimento de um projeto específico, o luminotécnico.

O projeto luminotécnico deve ser desenvolvido por consultores especializados, juntamente com a concepção da arquitetura, de modo a obter maior aproveitamento da luz natural e minimizando a incidência direta da luz do sol e o efeito do ofuscamento. Os requisitos de níveis de iluminância exigidos conforme a atividade do local estão previstos na norma NBR 5413 (ABNT, 1992 $)^{40}$, sendo que, em edifícios de escritórios, de uma maneira geral, os

\footnotetext{
39 Informação obtida junto ao eng. José Luiz De Martini, diretor da Gerencial Engenharia, em 26 Fev. 2009.

40 Esta norma encontra-se atualmente em processo de revisão de diversos critérios, principalmente aqueles relacionados ao perfil de usuários de edifícios comerciais com utilização plena de computadores.
} 
níveis das áreas de trabalho variam de 500 a 1000lux; dos corredores e escadas, de 75 a 150lux; e das garagens, de 100 a 200lux.

Além das considerações dos níveis de iluminância, o projeto luminotécnico deve contemplar as seguintes definições:

- A distribuição dos circuitos das luminárias, considerando luz natural próxima à área de janelas (circuitos paralelos à envoltória e sensores de nível de iluminância) e rotas de fuga de emergência;

- Os instrumentos de acionamento e controle das luminárias, tais como disjuntores, sensores de presença ou dimmers;

- O tipo de luminária para cada ambiente, com respectivas lâmpadas e reatores;

- As potências ou cargas elétricas das luminárias.

Estes dados são alguns dos pré-requisitos para a continuidade do projeto de instalações elétricas, principalmente na parte que envolve cálculo da potência a ser instalada no edifício e na alimentação dos circuitos. Outras premissas que afetam este cálculo são definidas pelo consultor em forma de considerações de cargas elétricas relacionadas à área e ao uso, por ser influenciado pela densidade de pessoas e pelo tipo de equipamentos. Projetistas experientes adotam, para projetos atuais, cargas médias para equipamentos e iluminação da ordem de $67 \mathrm{w} / \mathrm{m}^{2}$ (informação verbal ${ }^{41}$ ) nas áreas de escritórios, sem considerar o sistema ar condicionado, que é calculado à parte, devido ao seu grande diferencial em relação às outras cargas.

\subsubsection{Sistemas de geração de energia própria}

O sistema de geração de energia própria em edifícios de escritório é uma necessidade e objetiva, entre outras coisas, garantir uma autonomia mínima de funcionamento dos sistemas do edifício em casos de emergência e de falha no fornecimento da concessionária local, além de reduzir valores na conta de energia mensal. Os equipamentos previstos para serem atendidos pela geração própria de emergência geralmente são os ventiladores do sistema de pressurização e controle de fumaça, o sistema de iluminação para rota de fuga, os elevadores de emergência, os sistemas de segurança contra incêndio (tais como

$\overline{41}$ Informação obtida junto ao eng. José Luiz De Martini, diretor da Gerencial Engenharia, em 26 Fev. 2009. 
detectores, alarmes, bombas de incêndio e de chuveiros automáticos) e a parte eletrônica dos sistemas de controle e segurança patrimonial.

Além disso, De Martini (2008) faz referência a levantamentos em grandes edifícios, que mostram a existência de uma demanda contínua (24horas x 7dias) da ordem de 15\% a 25\% da capacidade nominal dos sistemas, associadas a atividades ininterruptas, tais como comércio exterior, call centers e plataformas de suporte a sistemas de tecnologia da informação, que também podem estar incluídas no sistema de geração de energia própria.

A tarifação da energia, diferenciada por horário, também influi na concepção do projeto elétrico e do sistema de geração própria. É muito comum haver previsão desta geração para o chamado horário de pico, quando a tarifa da concessionária é mais cara (tarifa horosazonal), para atendimento aos grandes centros consumidores do edifício, que são as centrais de ar condicionado e o conjunto de elevadores.

O sistema de geração de energia constitui-se de: grupo motogerador, alimentado a óleo diesel ou gás, cuja envoltória deve atender a requisitos de proteção contra incêndio e proteção acústica, tanto nos equipamentos quanto no ambiente; tomada de ar e escape de gases externos; além de requisitos especiais para armazenagem de combustível, previstas, no caso do Estado de São Paulo, no decreto n 46.076/01 do Corpo de Bombeiros.

Dependendo da quantidade de equipamentos a serem atendidos pelo sistema de geração própria, De Martini (2008) sugere que o mesmo seja composto por um conjunto modular de máquinas acionadas progressivamente, de acordo com a necessidade da demanda.

Outras tecnologias de geração autônoma, para reduzir gastos com a energia tarifada pela concessionária, e que envolvem a captação eólica e fotovoltáica, ainda não encontraram viabilidade econômica para serem implementadas em edifícios de escritórios brasileiros. De Martini opina que é mais importante investir no conjunto de soluções técnicas que permitam uma utilização racional da energia do que procurar fontes alternativas próprias (informação verbal $\left.^{42}\right)$.

${ }^{42}$ Informação obtida junto ao eng. José Luiz De Martini, diretor da Gerencial Engenharia, em 26 Fev. 2009. 


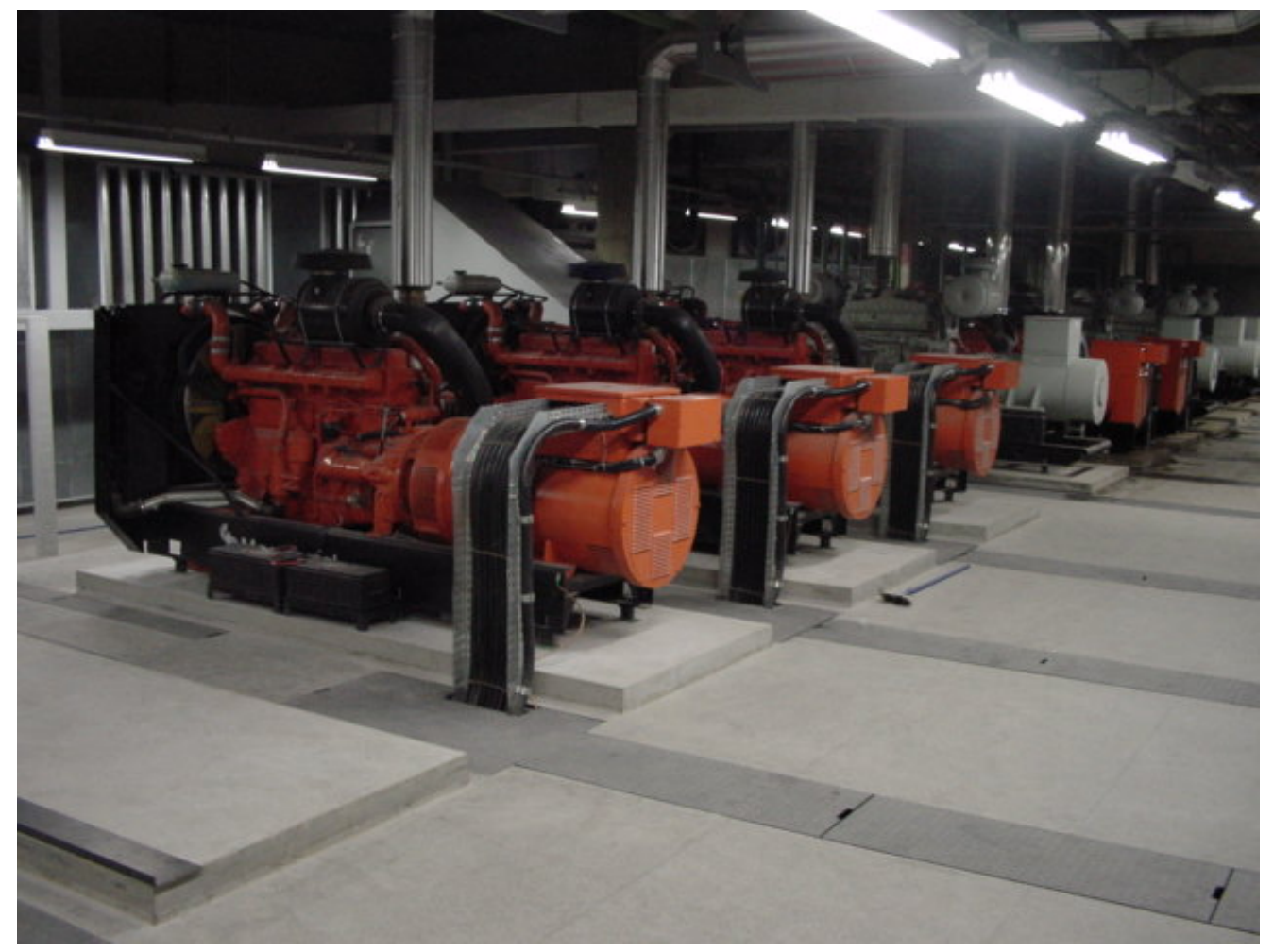

Figura 37 - Usina modular de geração de energia própria

Fonte: De Martini (2008)

\subsubsection{Aterramento predial e proteção contra descargas atmosféricas}

A norma NBR 5410 (ABNT, 2004) prevê que toda edificação deve dispor de uma infraestrutura de aterramento, denominada "eletrodo de aterramento", que pode estar contida na armadura do concreto das fundações. Normalmente associa-se a esta infraestrutura o sistema de proteção contra descargas atmosféricas (SPDA), que está contida na armadura do concreto da superestrutura (pilares) e associada a captores (para-raios na cobertura) e ligações equipotenciais. Este item ilustra um ponto onde parte da solução do sistema predial elétrico pode estar no detalhamento do projeto de estrutura. 


\subsubsection{Sistema de telecomunicações}

O sistema de telecomunicações envolve a transmissão de voz, dados, áudio e vídeo, e pode abranger diversos outros subsistemas, a depender da forma de transmissão em cada caso: telefonia, televisão, interfonia, áudio, vídeo e lógica ou informática.

Mesmo com os avanços da tecnologia sem fio nos equipamentos para telecomunicações, ainda é importante contar, nos projetos, com a rede tradicional com fio para fins de transmissão e recepção. Em termos de espaço, devem ser consideradas salas de telecomunicações no embasamento do edifício (térreo ou subsolo) e acessos às prumadas, em forma de armários no núcleo do pavimento, em todos os andares. As prumadas de telecomunicações devem adotar os mesmos cuidados das de elétrica, em termos de seccionamento entre andares. A distribuição no próprio andar, a partir do quadro, ocorre da mesma maneira que a dos circuitos elétricos: pelo forro e pelo piso. A opção de um empreendimento sem previsão para piso elevado obriga a utilização de uma modulação de instalações $^{43}$ para fazer esta distribuição em pontos fixos. Em alguns casos, há a necessidade de prever um ponto de antena para comunicação via satélite na cobertura e uma sala técnica, de aproximadamente $10 \mathrm{~m}^{2}$, próxima a ela.

\footnotetext{
${ }^{43}$ Ver seção 1.2.2.2 deste capítulo.
} 


\subsection{SISTEMAS DE SEGURANÇA}

Os sistemas de segurança nos edifícios de escritório podem ser classificados em duas categorias: segurança pessoal e segurança patrimonial. O sistema de segurança pessoal (ou life-safety) engloba o sistema de proteção da população em situações de emergência, principalmente no que se refere a combate a incêndios nas edificações, e o sistema de segurança patrimonial (security) envolve os sistemas de monitoração e controle de acessos, com o objetivo de preservar o patrimônio do edifício e de seus ocupantes.

\subsubsection{Sistemas de segurança pessoal}

Conforme já comentado no início deste capítulo ${ }^{44}$, o sistema de segurança pessoal envolve diversas disciplinas de contratação de projeto (arquitetura, instalações hidráulicas, instalações elétricas, ar condicionado) e, apesar de sua importância nos requisitos de desempenho do edifício, é freqüentemente tratado como um item de atendimento compulsório à regulamentação de corpos de bombeiros e prefeituras.

Segundo Ono (2007), isto decorre, em parte, pela falta desta disciplina específica nas escolas de arquitetura e engenharia e, em parte, pela natureza prescritiva de suas regulamentações. Este caráter prescritivo tem a função de garantir que um nível mínimo de segurança seja atendido, mas, ao mesmo tempo, não permite o desenvolvimento de soluções alternativas e criativas. Para possibilitar estas soluções, em alguns países, já há a discussão de códigos e regulamentações baseadas em desempenho, mas este nível de discussão só é possível quando os fundamentos teóricos que levaram à formulação das regras são de total domínio do arquiteto ou engenheiro envolvido nesta questão. Como exemplo, a proliferação de edifícios muito altos (com mais de 100 andares), em diversos países, suscitou a discussão sobre a possibilidade de se reservar um elevador, ou um grupo específico deles, para a utilização em caso de incêndio, contrariando uma regra já bem estabelecida de proibição deste uso. Como argumentos para fundamentar a discussão, os principais aspectos levantados são: o tempo total gasto para evacuação completa das pessoas neste tipo de edificação e, principalmente, o tempo de evacuação da parcela significativa da população com alguma dificuldade de locomoção em caso de emergência.

\footnotetext{
${ }^{44}$ Seção 3.1.
} 
Para ilustrar a conceituação que rege a regulamentação da proteção de incêndio, de uma forma geral, pode-se utilizar a árvore conceitual proposta pela NFPA (2002) e, por meio dela, estabelecer as ligações entre as disciplinas de projeto que contemplam seus requisitos, conforme Figura 38. Na regulamentação específica do Estado de São Paulo, considerada completa e rigorosa se comparada a outros Estados Brasileiros, esta conceituação aparece na forma de Instrução Técnica (IT-02 do decreto n 46.076/01).

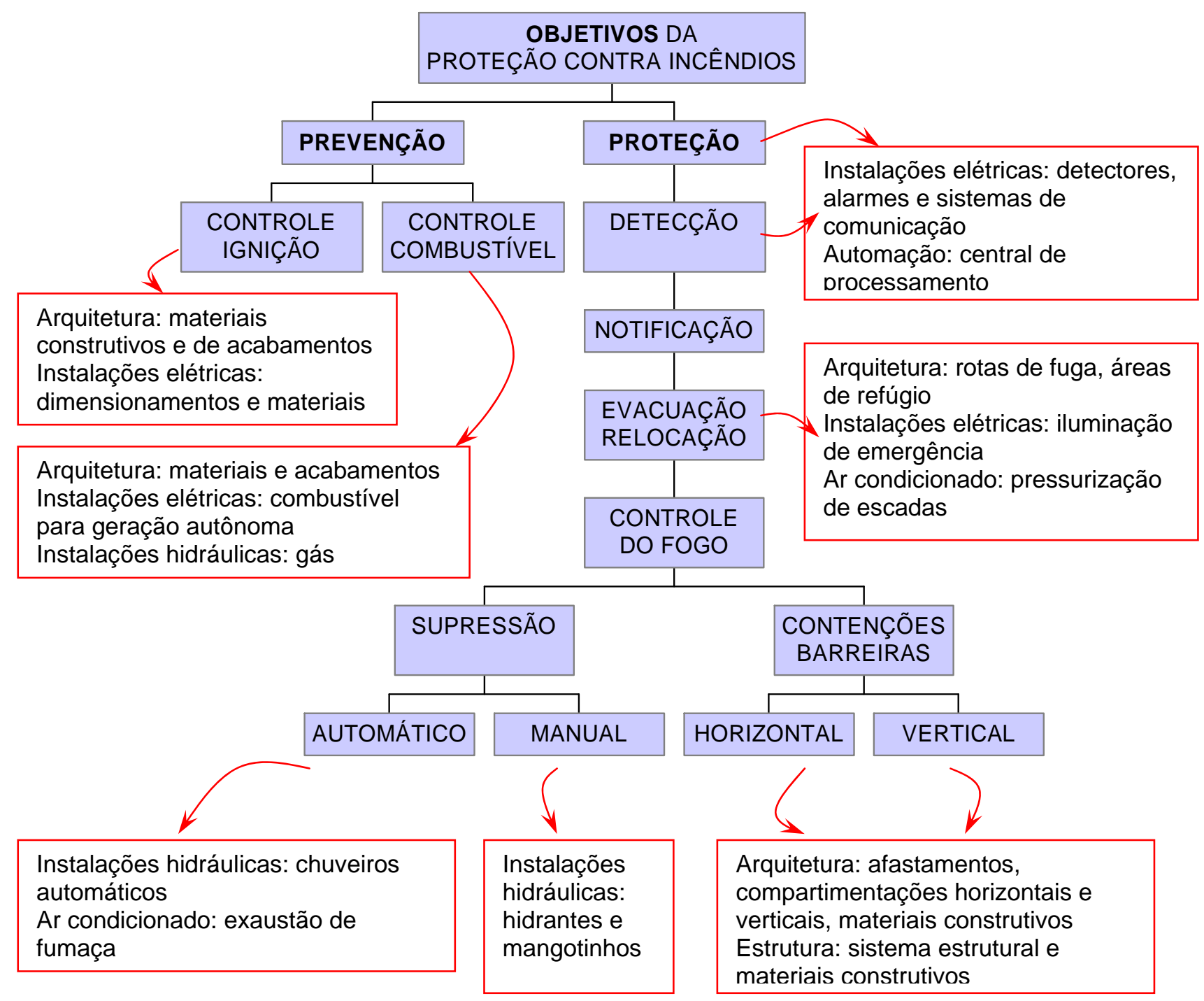

Figura 38 - Árvore conceitual da segurança contra incêndio e exemplos de disciplinas de projeto relacionadas

Fonte (árvore conceitual): NFPA (2002)

Por meio desta árvore conceitual e as diversas disciplinas de projetos relacionadas, pode-se inferir que os projetos de arquitetura e de estrutura têm importância fundamental nas 
questões relacionadas à segurança passiva contra incêndio das edificações, e que os componentes da segurança ativa são englobados pelos sistemas prediais.

O domínio da essência dos conceitos de requisitos de segurança, na fase de concepção de projeto arquitetônico, permite que sua inserção seja integrada e harmônica. Nos resultados parciais de estudos envolvendo edifícios brasileiros altos - a quase totalidade deles para uso de escritórios -, Ono (2007) detecta que os que têm concepção de origem norte-americana apresentam qualidade de projeto de segurança contra incêndio excelente, quando comparados aos demais edifícios, e que as falhas ou não-atendimento de itens avaliados nestes últimos decorrem da falta de conhecimento sobre as ferramentas básicas de medidas de segurança na etapa de desenvolvimento do projeto arquitetônico.

Os requisitos de projeto do sistema de segurança pessoal devem ser conhecidos na fase de concepção do projeto, pois interferem diretamente na formulação do pavimento tipo, ao regulamentar o número necessário de escadas de segurança, as rotas de fuga e as distâncias máximas a serem percorridas em caso de emergência.

\subsubsection{Sistema de segurança patrimonial}

Assim como no caso do sistema de segurança pessoal, esta disciplina dificilmente é encontrada nas escolas de engenharia e de arquitetura, sendo grande parte deste conhecimento adquirido segundo as práticas de mercado e orientação de autoridades de segurança. Um ponto de atenção do projeto de segurança patrimonial está na dificuldade de sua conciliação, em termos de organização dos espaços, com o projeto de sistema de segurança pessoal. O primeiro cria controles e, de certa forma, dificuldades para os acessos, e que o segundo pretende justamente liberar estes acessos. Uma forma encontrada para diminuir este conflito conceitual está na utilização de componentes eletrônicos para fazer o controle e a liberação destes acessos, e seu uso inteligente pressupõe uma estreita integração entre o sistema de segurança e o sistema de automação predial.

Segundo Leite (1997), o componente automatizado do sistema de segurança patrimonial contempla os seguintes subsistemas:

- Detecção perimetral: barreira perimetral, composta por sensores interligados a alarmes, cuja função é detectar a intrusão ou evasão de indivíduos na área controlada. 
- Sensoriamento interno: supervisão das áreas internas ao edifício, detectando anormalidades no acesso de pessoas. Normalmente associado ao sistema de controle de acessos e ao circuito fechado de televisão.

- Circuito fechado de televisão (CFTV): sistema composto por câmeras instaladas em pontos críticos, sob o ponto de vista da segurança, que captam e enviam imagens a uma central de segurança.

- Controle de acessos: sistema de gerenciamento de controle de entradas e saídas de pessoal (funcionários e visitantes), composto por: rede de processadores, unidades de leitura e respectivos cartões ou elementos de leitura.

- Controle de rondas: sistema composto por pontos de registro, em locais estratégicos, que controla os tempos de percurso dos vigias para cada posto, e detecta anormalidades quando o registro não é feito no tempo esperado. 


\subsection{SISTEMA DE AUTOMAÇÃO PREDIAL}

O conceito de automação em edifícios de escritórios está relacionado aos sistemas de gerenciamento das instalações prediais e é definido como o "sistema de processos automáticos de supervisão e controle dos diversos sistemas prediais e serviços, de forma integrada, tendo como suporte o computador" (LEITE, 1997).

Ainda segundo Leite (1997), as principais funções desempenhadas pelos sistemas de automação predial são: sistemas de gestão, segurança, controle de energia e controles adicionais.

- Sistemas de gestão: abrangem as funções de supervisão e controle dos sistemas prediais, propiciando sua manutenção, medições individualizadas e análises de funcionamento.

- Segurança: supervisão e controle de sistemas de controle de acesso, vídeo-observação, segurança perimetral, detecção e combate a incêndio e problemas de falha no suprimento de energia.

- Controle de energia: atuação sobre os equipamentos de medição e de grande consumo de energia, tais como sistemas de iluminação artificial e ar condicionado, com o objetivo de propiciar otimização energética das instalações.

- Controles adicionais: atuação sobre outros sistemas prediais da edificação, tais como controle de acesso de veículos, controle do suprimento de água potável e controle sobre persianas, entre outros.

O processo do sistema de automação predial consiste na interpretação automática de sinais de entrada, que são enviados por sensores ou detectores, e a geração de sinais de saída, representados por ações locais, tais como: liga/desliga, abre/fecha e outros. Para tanto, conta com unidades controladoras que realizam o processamento dos dados coletados e mandam os sinais de atuação sobre os equipamentos locais. Desta forma, diversos sistemas prediais podem ser conectados ao sistema de automação, entre os quais:

- Gerenciamento automático das instalações (elétrica, iluminação, hidráulica, condicionamento de ar);

- Economia energética;

- Controle dos serviços de segurança; 
- Pessoal: detecção e combate a incêndios;

- Segurança patrimonial: detecção perimetral, sensoriamento interno, circuito fechado de televisão, controle de acesso, controle de rondas;

- Automação de escritórios (redes de transmissão de dados de alta velocidade);

- Telecomunicações (redes internas ou sistemas de cablagem estruturada).

O nível de automação da resposta dada aos sinais de entrada, ou seja, quem decide a resposta (se um operador ou se uma máquina), define o nível de automação do sistema e do edifício. Um alto grau de automatização adotado é freqüentemente associado ao termo edifício inteligente, cuja conceituação abrange aspectos mais amplos. Duffy (1999), por exemplo, separa as funções do edifício de escritórios fazendo uma analogia ao universo dos computadores: em hardware e software. O hardware, em seu entender, compõe-se dos elementos físicos do edifício, que originam a arquitetura, o projeto de interiores e serviços ambientais; o software, por sua vez, é sua administração predial ao longo do tempo. A coordenação de ambos, de maneira que o projeto de edifício de escritórios seja eficiente e eficaz, fundamenta a visão de que o edifício inteligente integra de forma bem sucedida a administração predial (utilização plena das instalações físicas), a administração dos espaços (otimização do uso dos espaços internos) e a administração do negócio (exploração de possibilidades que deem suporte ao foco principal de negócios dos ocupantes). Hartkopf (1993), por sua vez, define o edifício inteligente como aquele que compreende, para as diferentes configurações de tecnologias recentes, os arranjos adequados dos aspectos físicos, ambientais e organizacionais, de modo a melhorar a velocidade, entendimento, comunicação e produtividade como um todo.

Desta forma, o sistema de automação predial é apenas uma parte componente do chamado edifício inteligente, e um projeto bem equacionado deste sistema está mais relacionado à boa solução das questões de concepção do projeto do que ao grau de sofisticação que o sistema pode oferecer. 


\subsection{SISTEMAS DE TRANSPORTE - ELEVADORES}

\subsubsection{Introdução}

Um grande marco na história dos edifícios altos refere-se à invenção do elevador de segurança. Apesar do uso de equipamentos mecânicos para transporte vertical de pessoas e cargas já ser há muito conhecido, é em 1852 que Elisha Graves Otis apresenta um dispositivo de segurança que freia o elevador em caso de rompimento do cabo que o transporta (SANTOS, A. B., 2007). O transporte vertical seguro, associado ao desenvolvimento de um sistema estrutural separado da vedação vertical, permitiu o surgimento dos edifícios de escritório do séc. XX e dos grandes arranha-céus que marcaram a história deste tipo de edificação.

Neste capítulo, discorriremos sobre as tipologias mais comuns de elevadores em uso no Brasil e as condicionantes do sistema que interferem diretamente na fase de concepção do projeto.

\subsubsection{Normas}

As recomendações para projeto de elevadores de passageiros nos edifícios são regidas pelas normas NBR 5665 (ABNT,1983), NBR NM 207 (ABNT,1999), NBR NM 313 (ABNT, 2007), NBR 9077 (ABNT, 2001), além de código de obras do município (em São Paulo, a Lei 11228/92).

\subsubsection{Tipos}

No mercado brasileiro, os tipos mais comuns de elevadores de passageiros em edifícios de escritórios são: 


\section{Elevador elétrico e máquina com engrenagem (geared elevator)}

Elevador cujo motor elétrico comanda uma unidade de redução por engrenagem que gira a polia de tração (Figura 39). A unidade de redução faz que o motor necessite de menos força para girar a polia, porém limita sua velocidade. Este sistema trabalha com velocidades típicas entre 0,65 a 2,5m/s, tornando-o eficiente em prédios residenciais (para os quais a norma não exige intervalo mínimo de tráfego) e, segundo Van Deusen (2002), em edifícios de escritórios com alturas medianas, de oito a doze andares.

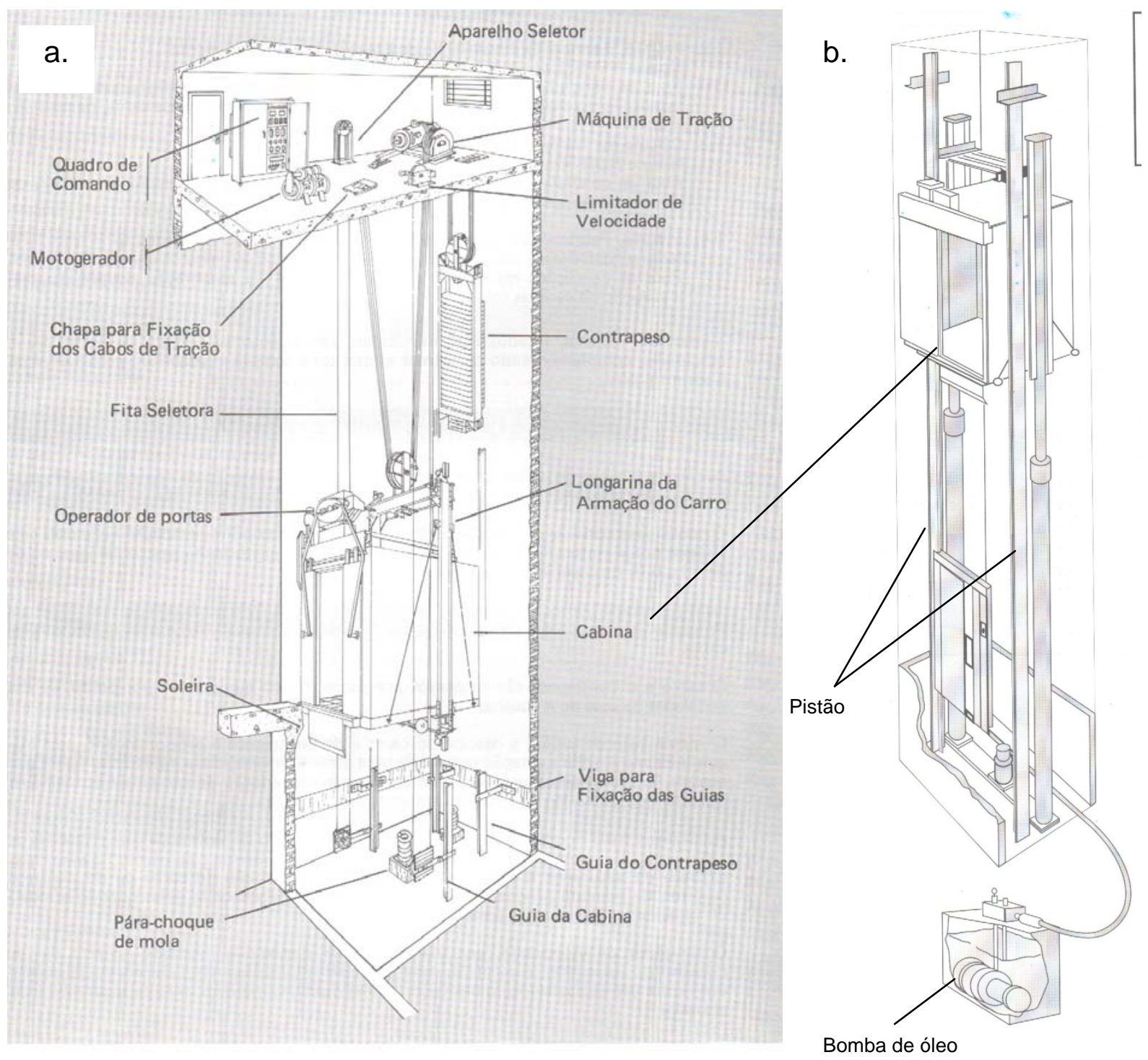

Figura 39 - Esquema básico de elevadores: (a) elétrico e seus componentes (válido para máquinas com e sem engrenagens) e (b) hidráulico

Fonte: (a) Elevadores Atlas Schindler (2001) e (b) Elevadores Otis (1996) 


\section{Elevador elétrico e máquina sem engrenagem (gearless elevator)}

Elevador que, por não contar com a unidade de redução (engrenagem), tem um motor mais potente e uma polia maior. É o mais utilizado em edifícios de escritórios, por contar com velocidades maiores que $2,5 \mathrm{~m} / \mathrm{s}$ e cuja máquina raramente necessita de substituição em uma eventual modernização do sistema (SANTOS, A. B., 2007).

\section{Elevador hidráulico}

Elevador que, ao invés de usar um sistema de tração com polias, utiliza um sistema de pistão que viaja dentro de um cilindro com óleo hidráulico (Figura 39). Este sistema permite viagens suaves e velocidades baixas, o que torna seu uso preferencial em percursos curtos (até oito andares). O sistema demanda uma casa de máquinas com previsão de tanque para o óleo. A casa de máquinas tem uma certa flexibilidade de posição, não necessitando estar exatamente na projeção do poço, como é o caso dos elevadores elétricos.

\section{Elevador sem casa de máquinas}

Elevador cujas dimensões de motor e polia permitem que o sistema seja montado no próprio poço, evitando a utilização de um espaço adicional, que seria a casa de máquinas (Figura 40). Também tem limitações de velocidade de transporte e altura do edifício (até 20 andares).

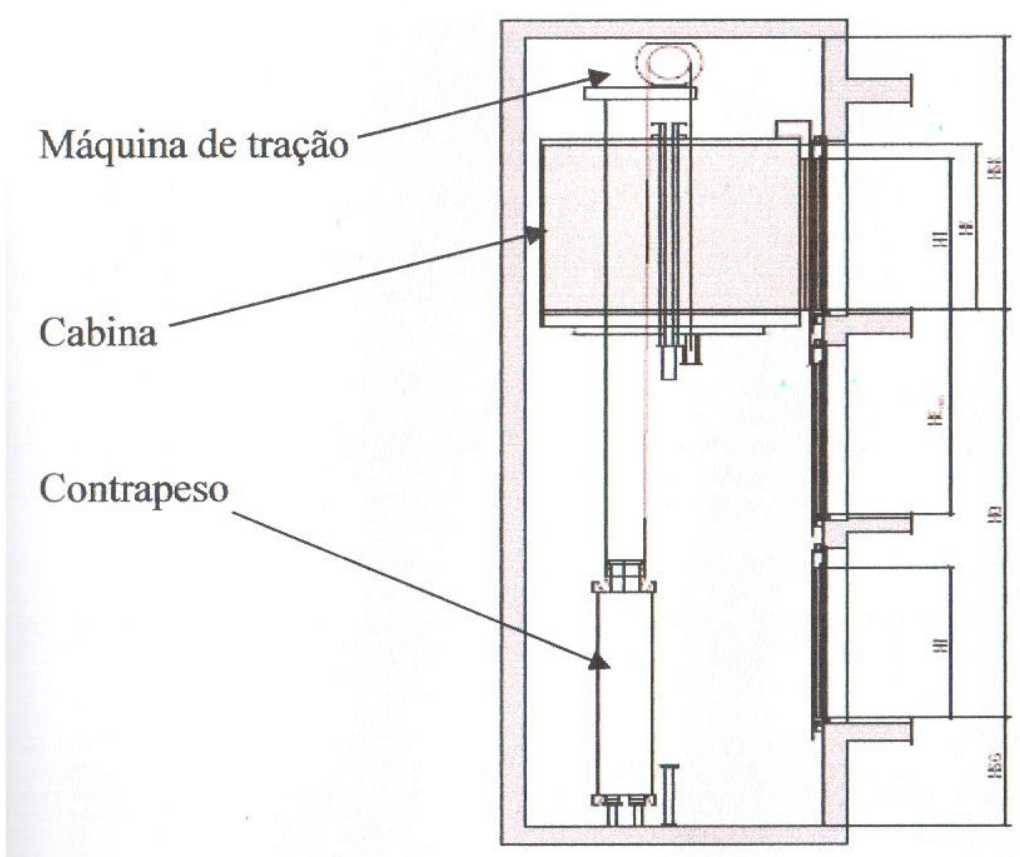

Figura 40 - Esquema simplificado de elevador sem casa de máquinas Fonte: Santos, A. B. (2007) 


\subsubsection{Cálculo de tráfego}

O cálculo de tráfego vertical de um edifício determina a quantidade, a capacidade e a velocidade dos elevadores que o atenderão. Isto tem impacto direto sobre o projeto do núcleo, no indicador de eficiência de uso de áreas do pavimento tipo, no nível de conforto que se deseja obter do sistema e na classificação mercadológica ${ }^{45}$ do edifício de escritório.

As variáveis que compõem este cálculo, e que são exploradas nesta seção, são:

- População do edifício

- Número de andares do edifício

- Alturas de piso a piso dos andares

- $\quad$ Tipos de portas dos elevadores

- Capacidade dos elevadores

- Velocidade dos elevadores

- Quantidade dos elevadores

$\underline{\text { População do edifício }}$

A população de um edifício é calculada de acordo com seu uso. A NBR 5665 (ABNT, 1983) prevê, para o uso de escritórios em geral e consultórios, o cômputo de uma pessoa a cada sete metros quadrados de sala ou área útil. Prevê, ainda, que podem ser computados 50\% da população nos pavimentos imediatamente acima ou abaixo do pavimento de acesso, desde que estes não estejam situados a mais de cinco metros do mesmo.

Outros usos que podem estar associados ao edifício de escritórios, tais como lanchonetes, lojas e salas de conferências, demandam relações diferentes entre número de pessoas e área. Isto deve ser observado no cálculo da população total do edifício.

\section{Número de andares do edifício}

Esta informação determina o número de paradas dos elevadores.

\section{Alturas de piso a piso dos andares}

Estas alturas, conjugadas com a informação do número de andares do edifício, determinam o percurso total dos elevadores. Para fins de cálculo, este percurso é considerado desde o piso acabado da primeira parada até o piso acabado da última parada.

\footnotetext{
${ }^{45}$ Ver seção 1.4 deste capítulo.
} 


\section{$\underline{\text { Tipos de portas dos elevadores }}$}

As portas podem ser de abertura central $(A C)$ ou abertura lateral (AL). A definição do tipo de porta, apesar de parecer muito técnica e específica, influi de maneira direta na análise de tráfego vertical do edifício, devido aos diferentes tempos de abertura e de fechamento das portas.

A largura destas portas também influi nesta análise (Figura 41). A NBR NW 207 (ABNT, 1999) pede uma largura mínima de $0,80 \mathrm{~m}$, que permite a passagem de uma pessoa por vez. Para a passagem de duas pessoas simultaneamente, a largura mínima necessária é 1,10m. Larguras intermediárias entre 0,80 e 1,10m permitem, portanto, a passagem de somente uma pessoa por vez, sendo que elas só se justificam no caso de acesso de equipamentos especiais ou deficientes físicos.

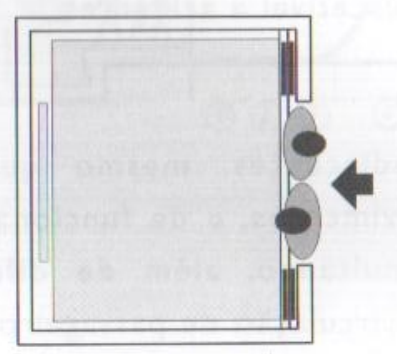

$A L \geq 1100$

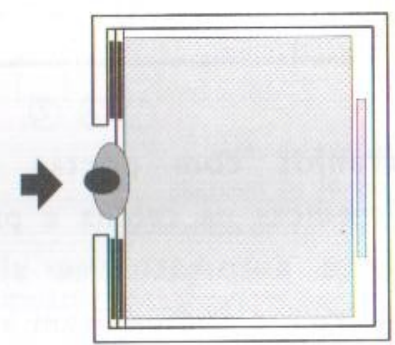

$\mathrm{AL}=800$

Figura 41 - Largura de portas de elevadores

Fonte: Elevadores Otis (1996)

\section{Capacidade dos elevadores}

A capacidade do elevador refere-se ao número máximo de passageiros que o mesmo transporta, descontando-se um, caso haja previsão de ascensorista. O número de passageiros define a área necessária para a cabine do elevador, cuja proporção de melhor funcionamento é a relação frente/ lado em torno de 3/2 (Figura 42). 


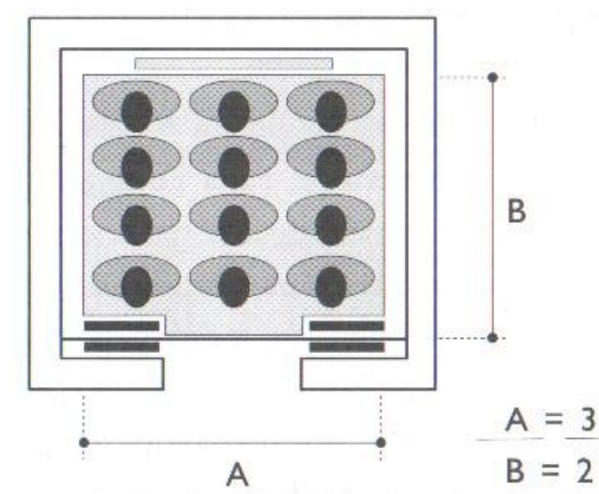

Figura 42 - Proporção da cabine do elevador

Fonte: Elevadores Otis (1996)

\section{Velocidade dos elevadores}

A velocidade ótima para os elevadores é definida após a análise completa do tráfego, pois, o incremento de velocidade do elevador melhora o seu desempenho, porém com um maior custo de aquisição. Para os cálculos iniciais, a velocidade é estabelecida em função da altura do edifício (Figura 43).

\begin{tabular}{|l|l|}
\hline Percurso $(\mathrm{m})$ & Velocidade $(\mathrm{m} / \mathrm{s})$ \\
\hline Até 17 & De 0,50 a 1,00 \\
\hline De 18 a 29 & De 1,00 a 1,75 \\
\hline De 30 a 44 & De 1,75 a 2,50 \\
\hline De 45 a 59 & De 2,50 a 3,50 \\
\hline De 60 a 74 & De 3,50 a 4,00 \\
\hline De 75 a 89 & De 4,00 a 5,00 \\
\hline De 90 a 150 & De 5,00 a 6,00 \\
\hline Acima de 150 & De 6,00 a 8,00 \\
\hline
\end{tabular}

Figura 43 - Velocidade de elevadores recomendada para edifícios não residenciais

Fonte: NBR 5665 (ABNT, 1983)

\section{Quantidade de elevadores}

Os elevadores são agrupados conforme os andares que atendem, para fins de cômputo no cálculo de tráfego. 


\section{Conceituação do cálculo}

A NBR 5665 (ABNT, 1983) define a capacidade de transporte dos elevadores, que é a quantidade de pessoas transportadas no intervalo de cinco minutos. Para o edifício de escritórios, a quantidade mínima prevista varia de 12\% (múltiplas entidades) a 15\% (entidade única) da população total do edifício. Esta diferenciação decorre do fato de que, nas entidades únicas, há intensa circulação de pessoas entre os andares, enquanto que nas entidades múltiplas, ocorre majoritariamente a circulação entre o andar da empresa ocupante e o térreo, e vice-versa. Este dado é importante na formulação do produto pelo empreendedor e na conceituação do projeto do arquiteto, pois a diferença de capacidades pode resultar em elevadores adicionais, problema que, se resolvido somente em etapas posteriores, pode inviabilizar o empreendimento.

Os dados de população transportada em cinco minutos e de intervalo de tráfego permitem a análise da eficiência do sistema. O intervalo de tráfego é o tempo de espera do passageiro, e seu cálculo considera também o tempo total de viagem de um elevador. Nesta viagem, são também consideradas as paradas prováveis (de acordo com a população da cabine e o número de paradas totais), os tempos de abertura de fechamento de portas, entrada e saída de passageiros, aceleração, desaceleração e corrida do carro do elevador. A NBR 5665 (ABNT, 1983) prevê intervalos de tráfego máximos para edifícios de escritórios de acordo com o número de elevadores (Figura 44).

\begin{tabular}{|clc|}
\hline \multicolumn{3}{|c|}{ Intervalo de Tráfogo } \\
\hline $\begin{array}{c}\text { Número de } \\
\text { elevadores }\end{array}$ & $\begin{array}{c}\text { Finalidade } \\
\text { do prédio }\end{array}$ & $\begin{array}{c}\text { Intervalo de } \\
\text { tráfego máximo } \\
\text { (s) }\end{array}$ \\
\hline \hline 1 & Geral lexceto apartamentos) & 80 \\
2 & Geral lexceto apartamentos) & 60 \\
3 & Geral (exceto apartamentos) & 50 \\
\hline \hline 4 ou mais & Escritórios de uma única entidade & 40 \\
& Escritorios om geral o consultórios & 40 \\
\hline
\end{tabular}

Figura 44 - Intervalos de tráfego admissíveis para edifícios de escritórios

Fonte: NBR 5665 (ABNT, 1983)

A qualidade do serviço de transporte, que se estabelece em função do intervalo de tráfego (quanto menor o intervalo, melhor é a qualidade), tem seus requisitos mínimos determinados por norma, mas, dependendo do produto imobiliário que o empreendedor pretende oferecer, pode ser incrementada. Um bom estudo de tráfego equaciona, de modo econômico, a qualidade de serviço e a capacidade de tráfego. 
O cálculo de tráfego para determinação do tipo e número de elevadores pode ser feito pelo próprio arquiteto, seguindo a NBR 5665 (ABNT, 1983) e manuais de fabricantes, ou por consultor especializado. Há também softwares de cálculo disponibilizados pelos fabricantes de elevadores nacionais, que podem ser utilizados para um pré-dimensionamento nos estudos de viabilidade do projeto. Na consolidação do mesmo, porém, é importante a validação por parte de uma consultoria especializada, pois o sistema de elevadores é um item de aquisição relativamente cara e cuja compra deve ser feita com grande antecedência em relação ao cronograma de obra.

\subsubsection{Disposição nos pavimentos}

Não há uma regra específica para a disposição dos grupos de elevadores. Alguns fabricantes nacionais (Atlas Schindler e Otis) sugerem arranjos em linha com largura máxima de três elevadores, e arranjos em alcova, isto é, dispostos frente a frente em hall comum, de quatro a oito elevadores (Figura 45). Van Deusen (2002) também sugere que um grupo de elevadores tenha a largura máxima de quatro unidades, de modo a facilitar o acesso do passageiro, que está no hall de espera, a qualquer um deles.

\subsubsection{Elevadores de uso especial}

Existem tipologias específicas de elevadores, relacionadas a seu uso. Em edifícios de escritórios, as mais comuns são:

- Elevadores para passageiros e carga: têm dimensões maiores de cabine, acabamentos para resistir a impactos ocasionais de transporte de mobiliário e equipamentos e grande capacidade de carga. Não devem ser confundidos com monta-cargas, que são elevadores exclusivos de carga e não permitem o acesso de passageiros;

- Monta-cargas: elevadores de dimensões especiais para transporte exclusivo de cargas;

- Elevador de emergência: obrigatório, em São Paulo, quando o edifício tem mais de 60m de altura (IT-11, Decreto Estadual 46076/01), é dotado de antecâmara própria, deve atender a todos os andares do edifício e tem especificidades em relação à alimentação elétrica e detalhes de poço; 
Dois elevadores - arranjo em linha

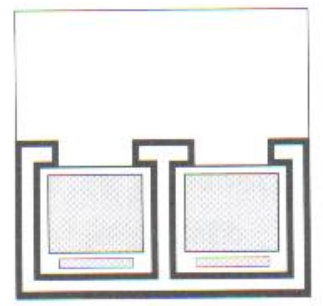

Três elevadores - arranjo em linha

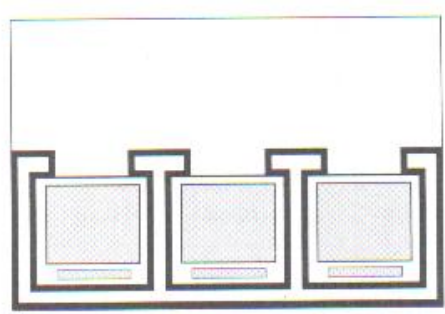

Quatro a oito elevadores - arranjos em alcova
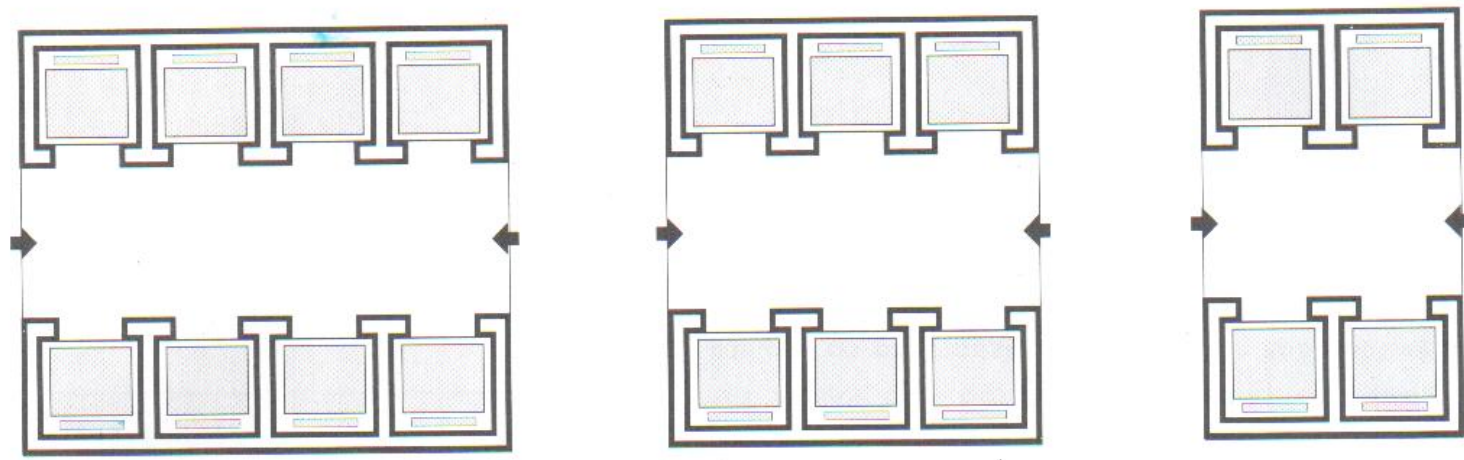

Figura 45 - Sugestão de arranjos de elevadores em hall

Fonte: Elevadores Otis (1996)

- Elevadores para deficientes: a plena acessibilidade ao edifício, prevista na norma NBR 9050 (ABNT, 2004), tem disposições específicas para elevadores, regidas pela NBR NM 313 (ABNT, 2007), que trata de cuidados, como a largura mínima de portas, dimensões de cabine, comandos com leitura em braile e avisos sonoros de chegada ao andar;

- Elevadores com dois pavimentos: elevadores cuja cabine e paradas atendem simultaneamente a dois pavimentos. Normalmente o térreo conta com um mezanino, ligado por escadas rolantes, para direcionar o fluxo de entrada de passageiros. Os que entram em andares pares, descem em andares pares, e os que entram em andares ímpares, descem em andares ímpares. Sua vantagem consiste em aumentar consideravelmente a capacidade de tráfego sem aumentar a projeção do pavimento em planta. Segundo Van Deusen (2002), por se tratar de uma solução extremamente cara, só é viável em edifícios com exigências muito específicas, tais como capacidade de transporte superior a 25\%, ou como elevador expresso para edifícios com mais de 100 andares. 


\subsubsection{Soluções para desempenho do sistema}

O sistema de elevadores consome uma quantidade considerável de energia no uso e operação do edifício. Segundo Dal Monte (2000), "o consumo de energia elétrica dos elevadores representa em média 5\% (prédios comerciais) ou 6\% (prédios residenciais) do valor global do condomínio". Com os custos crescentes deste recurso, as empresas fabricantes têm apresentado alternativas com a finalidade de tornar o sistema energeticamente mais eficiente.

Uma delas refere-se a um sistema de antecipação de chamada (Figura 46), cujo controle, no hall do andar, pede que o passageiro identifique o andar ao qual vai se dirigir, para então definir qual elevador deve atendê-lo. Este sistema tem por finalidade reduzir as paradas prováveis de um sistema convencional, ao agrupar em andares próximos o destino de cada elevador e, assim, reduzir os intervalos de tráfego. Com isso, em teoria, é possível reduzir a quantidade total de elevadores de um conjunto, sem prejuízo de conforto do usuário.

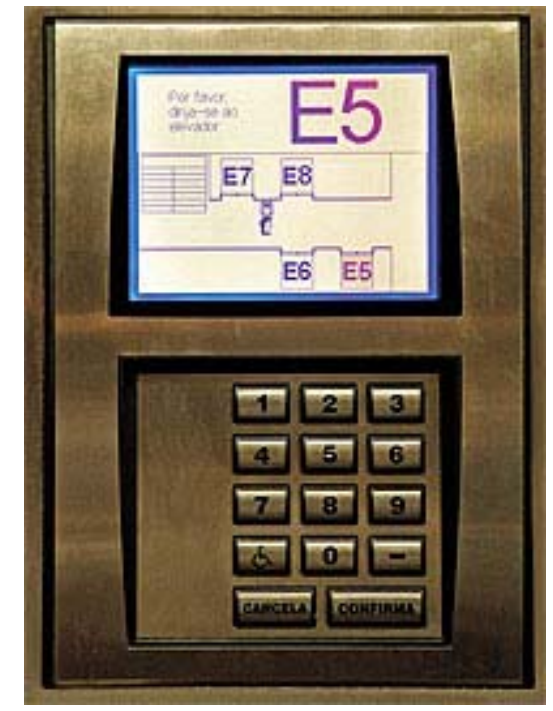

Figura 46 - Controle do sistema de antecipação de chamadas

Fonte: Faria (2008)

Outra alternativa interessante refere-se a um sistema de dispositivos (drives) regenerativos de energia elétrica, que aproveita o princípio do uso do contrapeso nos elevadores para produzir uma pequena quantidade de energia quando o uso dos motores é pouco solicitado (quando a cabine desce cheia ou sobe vazia). Versões mais sofisticadas destes dispositivos convertem, também, a energia gasta na frenagem dos elevadores. 


\subsubsection{Processo de aquisição}

O processo de aquisição do sistema de elevadores tem influência no projeto de outras disciplinas porque alguns requisitos de espaços, tais como dimensões da casa de máquinas, pontos de gancho no seu teto e confirmação de medidas de poço, variam de acordo com o produto escolhido e com o fabricante. O projeto que contém estas informações é o de montagem do fabricante e só é fornecido após a contratação comercial do sistema. Como ele pode influenciar nos projetos de estrutura (cargas dos ganchos), arquitetura (dimensões) e sistemas prediais (cargas elétricas e drenagem de poço), é importante que o arquiteto ou o coordenador de projetos prevejam em seus cronogramas a necessidade da entrada destas informações no desenvolvimento do projeto e sinalizem ao empreendedor as dataslimite para sua compra.

Os prazos com que os fabricantes nacionais trabalham usualmente são de cerca de 30 dias, após o fechamento comercial, para entrega do projeto de montagem (que deve ser aprovado pelo arquiteto ou consultor especializado) e seis meses para entrega do sistema, após a aprovação do projeto.

\subsubsection{Manutenção}

Segundo Dal Monte (2000), os padrões de contrato de manutenção mais comuns no Brasil são:

Manutenção integral: contrato com direito à substituição da maioria ou todas as peças do equipamento;

Manutenção parcial: contrato que discrimina as peças que podem ser repostas sem ônus ao proprietário;

Conservação simples: contrato sem cobertura para reposição de peças.

Em todos os contratos, estão previstos a manutenção de rotina e o atendimento de emergência em caso de pane dos elevadores. Segundo Martins (informação verbal ${ }^{46}$ ), além dos contratos de manutenção serem padronizados, a forma de contratação é praticamente por adesão, com poucas possibilidades de se modificar os itens de escopo.

46 Informação obtida em entrevista com o eng. Alexandre V. Martins, Gerente de Engenharia da Hochtief Facility Management do Brasil, em 03 Nov. 2009. 
Atualmente, há a possibilidade de se incluir o monitoramento e diagnóstico remoto dos elevadores, de maneira a permitir uma resposta mais rápida da equipe de manutenção (FARIA, 2008).

Van Deusen (2002) sugere alguns itens relevantes, adotados em empreendimentos norteamericanos, a serem considerados em contratos de manutenção de elevadores em edifício de escritórios:

- Requisitos de desempenho, inclusive tempos de percurso de piso a piso, tempo de abertura e fechamento de portas, tempo por que a porta do elevador permanece aberta após uma chamada, entre outros;

- Tempo máximo de espera do atendimento de emergência em caso de pane do elevador: 30 min em horário comercial e 60min fora dele;

- Número tolerado de panes por unidade, por mês;

- Penalidades quando o número tolerado for ultrapassado.

Estes itens demonstram uma preocupação com o desempenho de funcionamento do sistema, diferentemente do que é abordado nos contratos de manutenção tradicionais brasileiros.

\subsubsection{Escadas rolantes}

A norma que rege o projeto para escadas rolantes é a NBR NM 195 (ABNT, 1999). Seu uso é recomendado para escoamento de grande número de pessoas em percursos curtos. As larguras de seus degraus são padronizadas em 0,60, 0,80 e 1,00m, e seu ângulo de inclinação, em $30^{\circ}$ e $35^{\circ}$. Como sua capacidade de tráfego é relativamente alta, é necessário considerar o espaço de acomodação destas pessoas nos andares, principalmente se houver uma continuação de percurso para outra escada rolante. Várias disposições são possíveis, e a Figura 47 ilustra alguns exemplos.

Um cuidado necessário na definição da escada rolante consiste na sua real capacidade de tráfego. A capacidade fornecida pelos fabricantes retrata uma condição de uso pleno, somente observada em horários de picos de estações de metrô. A capacidade real, em edifício de escritórios, e mesmo em shopping centers, considerando o espaço de conforto mínimo dos usuários, é cerca de 35 a 40\% menor (Tabela 7). 

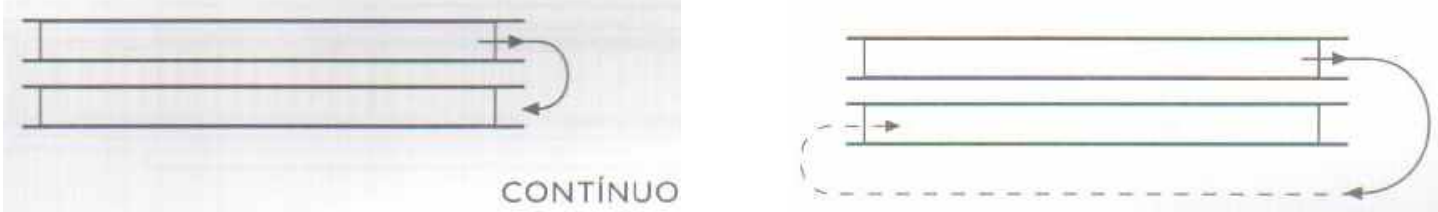

SEPARADO

\section{Disposição em corte}
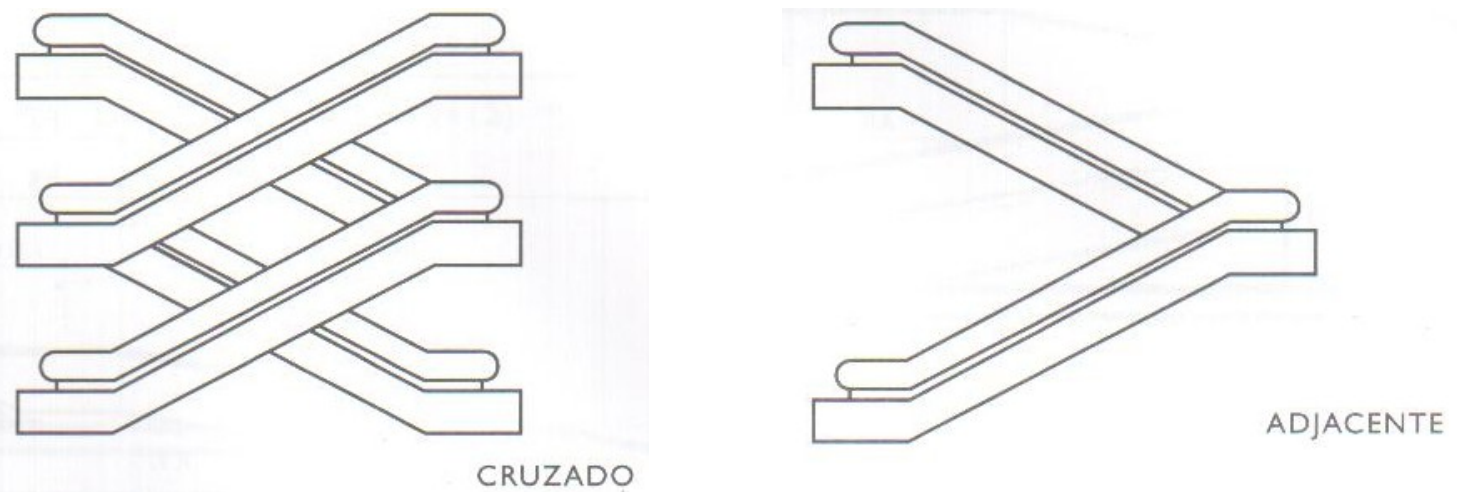

Figura 47 - Exemplos de disposições de escadas rolantes

Fonte: Manual do projetista - Elevadores Otis (1996)

Outro cuidado a ser tomado é, da mesma forma como os elevadores, não considerar as escadas rolantes como rota de fuga, nem suas capacidades de tráfego no cálculo de escoamento da população, em casos de emergência.

Tabela 7 - Capacidade de tráfego de escadas rolantes

\begin{tabular}{ccc}
\hline Largura do degrau (metros) & $\begin{array}{c}\text { a)Capacidade nominal } \\
\text { (pessoas / hora) }\end{array}$ & $\begin{array}{c}\text { b)Capacidade real (pessoas / } \\
\text { hora) }\end{array}$ \\
\hline 0.60 & 4500 & 3000 \\
\hline 0.80 & 6750 & 4200 \\
\hline 1.00 & 9000 & 5400 \\
\hline
\end{tabular}

Fonte: a) Atlas Schindler (2001); Otis (1996) e b) Van Deusen (2002) 


\section{CAPÍTULO C - ASPECTOS DE GESTÃO}

\section{GESTÃO DE PROJETOS}

\subsection{CONCEITOS}

O termo "gestão de projetos" vem da expressão "project management", cuja tradução mais provável é "gestão de empreendimentos". Segundo o PMI (2000), "um projeto é um empreendimento temporário com o objetivo de criar um produto ou serviço único". Gido e Clements (2007) entendem o projeto como "o esforço para se atingir um objetivo específico por meio de um conjunto único de tarefas inter-relacionadas e da utilização eficaz de recursos" e sua gestão como algo que "envolve um processo de primeiro estabelecer um plano e depois implementá-lo para atingir o objetivo do projeto". Estas definições denotam a abrangência do conceito de projeto, que supõe que o mesmo pode ser uma atividade singular de qualquer área do conhecimento.

O conceito de projeto a ser adotado para este capítulo e para o trabalho como um todo vem da expressão "design" e, como produto, refere-se à produção da documentação que é gerada para entendimento e execução de empreendimentos imobiliários. Em paralelo a uma das atribuições que o PMI (2000) deu ao projeto como "project", o projeto "design" também deve ser entendido como uma prestação de serviços, conforme conceituado por Melhado e Agopyan (1995) como

atividade ou serviço integrante do processo de construção, responsável pelo desenvolvimento, organização, registro e transmissão das características físicas e tecnológicas especificadas para uma obra, a serem consideradas na fase de execução.

A gestão, neste caso, é do processo de projeto, ou design management, que pode ser entendida como a gerência ou a administração de um processo que se inicia com uma idéia, continua com a geração de documentação completa (cujos parâmetros geram a construção de um edifício), e finaliza após a ocupação e uso da edificação. Este processo pode ser dividido em etapas específicas para o segmento de empreendimentos imobiliários, podendo ser destacadas cinco principais: planejamento, elaboração de projetos, preparação para execução, execução e uso da edificação (ROMANO, 2003). 
A gestão do processo do projeto também pode ser definida, segundo Melhado et al. (2005), como o

conjunto de atividades relacionadas com o planejamento, organização, direção e controle do processo de projeto, assim como atividades de natureza estratégica (...) e táticas, tais como a seleção e contratação dos membros da equipe de projeto, com a finalidade de garantir a qualidade (...) do produto-serviço oferecido (o projeto).

A qualidade deste projeto envolve também os aspectos abstratos do projeto arquitetônico, que devem encontrar uma ligação com os aspectos puramente técnicos da engenharia. A importância atual desta integração, além do trabalho multidisciplinar entre diferentes agentes do processo, pode ser vista em diversos trabalhos publicados em periódicos internacionais, notadamente o AEDM ${ }^{47}$.

Muitos conceitos da gestão do processo do projeto "design" são oriundos ou adaptados da gestão do projeto "project", razão pelo qual os itens explorados a seguir sobre a gestão deste processo ("design"), que tratam de seu planejamento e suas principais etapas, trazem várias referências conceituais à gestão de projetos ("project").

\footnotetext{
${ }^{47}$ Architectural Engineering and Design Management (www. earthscan.co.uk/Default.aspx?tabid=502)
} 


\subsection{PLANEJAMENTO DO PROCESSO DE PROJETO}

O planejamento para o processo do projeto, em termos gerais, segue o mesmo princípio de planejamento para qualquer outro tipo de processo, devendo responder às principais questões, tais como o que vai ser feito (o escopo), quando vai ser feito (o prazo), quem vai fazer (os responsáveis) e quanto vai custar (os custos). Tzortzorpoulos (1999) descreve o planejamento como a etapa do processo de projeto que se destina à concepção, definições, análise e avaliação do conjunto de informações técnicas e econômicas iniciais e estratégias do empreendimento.

Gido e Clements (2007) esclarecem que:

Esse esforço de planejamento inclui a definição clara de objetivos, a divisão e a subdivisão do escopo do projeto em "frações" significativas chamadas pacotes de trabalho, a definição das atividades específicas que deverão ser conduzidas para cada um deles, a representação gráfica das atividades na forma de diagrama de rede, a estimativa do tempo que cada atividade levará para ser concluída, a definição dos tipos de recursos e a quantidade necessária de recursos para dada atividade, a estimativa do custo de cada atividade e o cálculo do cronograma e do orçamento do projeto.

A organização de todas estas informações de forma lógica e concisa implica em processos de modelagem do planejamento, que podem ser feitos por diversas ferramentas disponíveis no mercado. Contudo, a modelagem para o caso específico do processo do projeto de empreendimentos imobiliários não pode ser vista como uma tarefa simples, devido às suas peculiaridades, principalmente multidisciplinaridade e atividades dependentes e simultâneas. Muitas vezes o planejamento do processo do projeto é confundido com o planejamento de prazos, pois o produto final deste último, o cronograma, responde à maioria das questões que interessam ao empreendedor. É importante salientar que o planejamento do processo do projeto envolve outras questões, tais como: requisitos para seu controle; requisitos para análise crítica e verificação de etapas; e as ferramentas disponíveis para comunicação e trocas de informação. 


\subsubsection{Escopo}

O termo escopo, no contexto do projeto, pode se referir ao escopo do produto - aspectos e funções que caracterizam um produto ou serviço - e ao escopo de projeto - o trabalho que deve ser feito com a finalidade de fornecer um produto (PMI, 2000). O escopo do projeto de edifício de escritórios pode ser considerado como o escopo do produto. Ele pode ser dividido em dois principais grupos: o escopo do empreendimento, ou do produto imobiliário, e o escopo de cada disciplina de projeto.

O escopo do empreendimento é composto pelas diretrizes iniciais determinadas pelo empreendedor. Estas diretrizes, geralmente em forma de dados analíticos e traduzidas posteriormente pelos arquitetos e projetistas (Figura 48), determinam não só a configuração física do edifício, mas também suas linhas gerais de operação e de desempenho econômico e financeiro. Elas resumem as expectativas do empreendedor para o projeto e são as principais referências para posterior avaliação de seu sucesso.

Kohn e Katz (2002) enumeram estas diretrizes iniciais em forma de objetivos de desenvolvimento, na visão do empreendedor:

- Objetivos do empreendedor (venda, aluguel, construção customizada, uso próprio);

- Nível de acabamentos;

- Tipos de usuários a que se deseja atingir;

- Classificação mercadológica do edifício;

- Prioridades de projeto (durabilidade, flexibilidade, possibilidade de ampliações futuras, efeito da paisagem no interior do prédio, qualidade do ambiente de trabalho, premissas para redução de prazos de construção, entre outros);

- Eficiência no uso de áreas do projeto.

Já a definição do escopo das disciplinas componentes do projeto - e quais considerar - tem importância fundamental para assegurar um trabalho de gestão de processo de projeto bem sucedido. Quanto mais esta definição é feita de modo precário, maior é a probabilidade de conflitos posteriores entre agentes e atrasos no processo do projeto, devido a lacunas ou entradas tardias de informações. Uma definição bem feita de escopo também permite sua eventual alteração, de forma a evitar discussão de mérito entre as partes. Os manuais de escopo de serviços de projetos e de coordenação de projetos da indústria imobiliária ${ }^{48}$, apesar de sua forte conotação para as edificações residenciais, servem como ferramenta

\footnotetext{
${ }^{48}$ Ver seção 1.3 deste capítulo.
} 
inicial de orientação para definição de escopo de contratação das disciplinas de projeto para edifícios de escritórios, principalmente pela ênfase na abordagem das atividades desenvolvidas.

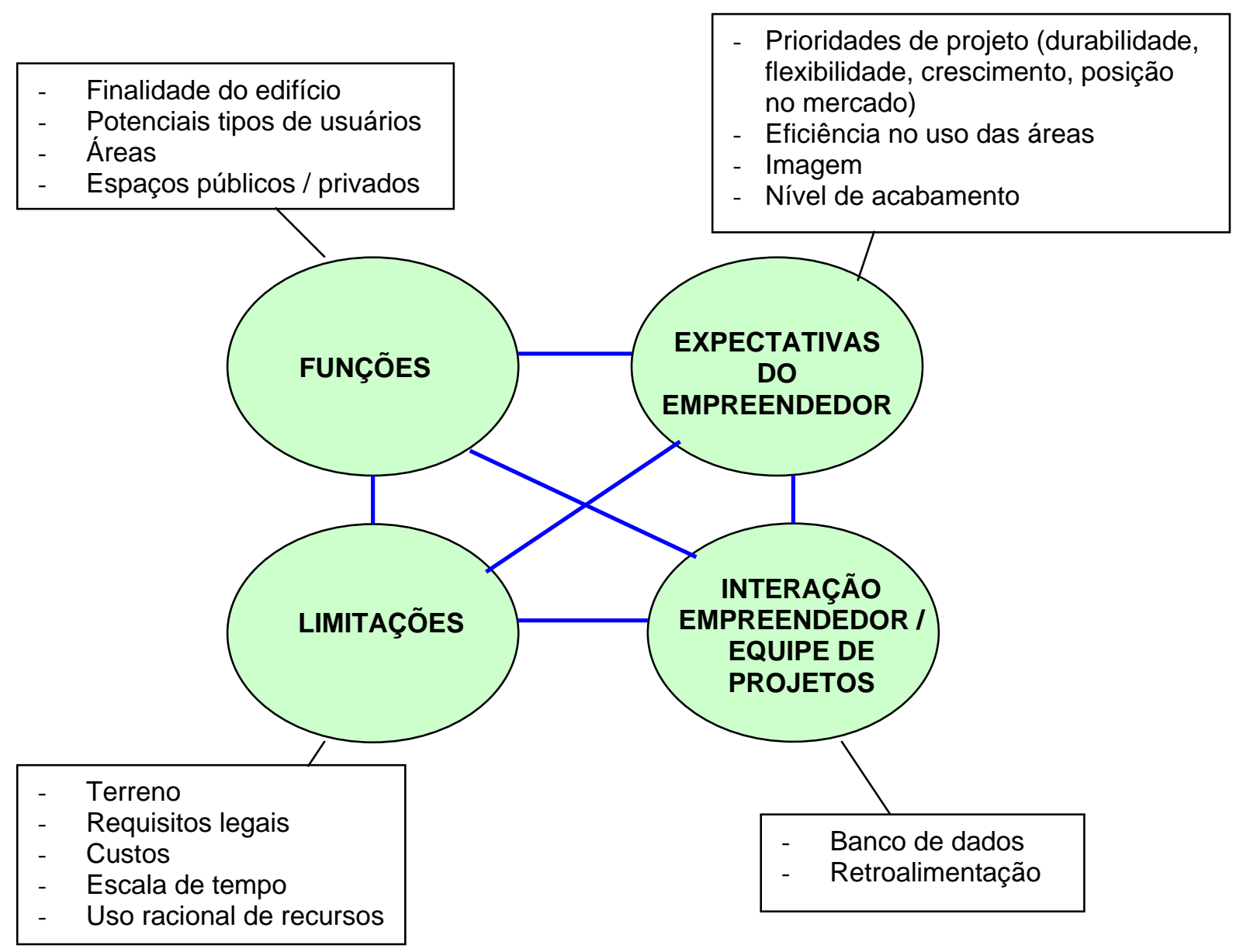

Figura 48 - Formulação do escopo do empreendimento em edifícios de escritório

Baseado em Crane; Dixon (1991) e Kohn; Katz (2002)

A alteração de escopo, por sua vez, deve ter procedimentos previamente determinados entre empreendedores e seus contratados. Via de regra, estes procedimentos contam com a documentação formalizada dos pedidos de alteração, seus motivos, custos e aprovações. Esta documentação pode contar com formulários específicos ou estar incorporada aos demais documentos gerados no decorrer do processo natural do desenvolvimento do projeto, como atas de reunião e correspondências formais. 


\subsubsection{Prazos}

A gestão de prazos para o desenvolvimento do projeto refere-se ao conjunto de atividades requeridas para assegurar que o projeto seja elaborado dentro do prazo previsto (MELHADO et al., 2005). No mercado imobiliário, o cumprimento de prazos e cronogramas é um problema recorrente, sendo que alguns projetistas consideram a qualidade do projeto inconciliável com o cumprimento de cronogramas (MANZIONE, 2006, MELHADO et al., 2005).

O planejamento de prazos em projetos é freqüentemente associado a uma modelagem do processo na forma de um cronograma, que ilustra graficamente as atividades a serem desenvolvidas, os seus responsáveis, a duração das mesmas e as ligações de dependência e precedência. Equivocadamente, muitos agentes do processo dão importância exclusiva às datas principais de entrega de etapas. Manzione (2006) já alertava para o uso do cronograma como mero "instrumento acessório para o controle das entregas dos desenhos contratados junto aos projetistas, e não como um condutor do processo gerencial".

O planejamento de prazos, como processo em si, pode ser melhor entendido sob a ótica do PMI (2000), que enumera os seguintes sub-processos necessários: definição das atividades: identificação das atividades que devem ser realizadas para produzir os sub-produtos de projeto; seqüenciamento das atividades: identificação e documentação das relações de dependência entre as atividades; estimativa da duração das atividades: estimativa da quantidade de períodos de trabalho necessários para a implementação de cada atividade; desenvo/vimento do cronograma: análise da seqüência das atividades, sua duração e os requisitos de recursos para a criação do cronograma de projeto; e controle de cronograma: controle das mudanças do cronograma de projeto.

Existem diversas ferramentas, ou técnicas de modelagem, para se fazer este planejamento, sendo algumas: diagramas de GANTT (diagramas de barras), redes PERT-CPM (uso conjugado da Técnica de Avaliação e Revisão de Projetos e do Método do Caminho Crítico), DFD (Diagramas de Fluxos de Dados) e $D S M^{49}$ (Matriz Estruturada de Projeto). Os cronogramas de projeto em forma de diagrama de barras são muito difundidos, devido a sua simplicidade, mas não atendem às complexas trocas de informações entre disciplinas, muito comuns nos processos de projeto. Coordenadores experientes até conseguem inserir boa parte destas trocas nos diagramas de barras, mas a dificuldade na previsão de todas interações entre atividades aumenta junto com a complexidade do projeto. Manzione (2006)

49 Sigla para Design Structure Matrix, também conhecido como Dependency Structure Matrix e Design Precedence Matrix. Conceitos e tutoriais disponíveis em: <www.dsmweb.org>. 
descreve uma metodologia de planejamento $\left(A d e P T^{50}\right)$ que, de certa forma, preenche esta lacuna de interações das atividades (incluindo as interações simultâneas), ao analisar as atividades, seus níveis hierárquicos e as precedências de informação por meio de um mapa em forma de matriz (a $D S M$ ), permitindo uma ordenação coerente destas atividades e possibilitando uma otimização de cumprimento de prazos para elas. Atualmente esta metodologia está disponível em caráter comercial em forma de softwares e consultorias especializadas $^{51}$.

Qualquer que seja a metodologia empregada ou a ferramenta utilizada para modelagem, o planejamento de prazos factíveis para um projeto passa pelo planejamento correto do seu processo como um todo.

\subsubsection{Agentes envolvidos e configuração de equipes}

O tipo, a formatação e mesmo a localização do negócio imobiliário fazem que a forma de atuação dos agentes no processo de gestão de projetos seja variável para cada tipo de empreendimento. Há desenvolvimento de edifícios de escritórios para uso corporativo e para vários tipos de comercialização (venda do todo ou parte, aluguel do todo ou parte, construção sob medida, entre outros). Genericamente, podemos citar como agentes presentes na maioria dos processos de projetos de edifícios de escritórios os elencados abaixo:

- Empreendedores (geralmente os contratantes de projeto, podem ser eventualmente os usuários finais da edificação);

- Arquitetos, projetistas e consultores, que traduzem as necessidades dos empreendedores em idéias e documentos (os projetos);

- Construtores, que constroem o que foi projetado e cuja atuação na gestão dos projetos é elaborar os projetos de produção, quantificar em custos as soluções técnicas e fornecer retroalimentação aos projetistas das soluções exeqüíveis ou não;

- Usuários, que utilizam o edifício projetado, e que fornecem dados de retroalimentação aos projetos por meio de avaliações pós-ocupação;

\footnotetext{
${ }^{50}$ Analytical Design Planning Techniques, metodologia investigada inicialmente por Austin et al. (1999).

${ }^{51}$ Como exemplo, <www.adeptmanagement.com>.
} 
- Administradores prediais e gerenciadores de facilidades, que operam o edifício, efetuam a sua manutenção e também contam com sua parcela de retroalimentação para os projetos;

- Órgãos governamentais, que, por meio da legislação e normas, regulam as atividades relacionadas a projeto, construção, licenças e, em alguns casos, financiamentos.

\subsubsection{Importância do coordenador de projetos}

Além dos três primeiros agentes mencionados, ainda aparece a figura do gestor ou coordenador de projetos, sem o qual o planejamento do processo do projeto inexiste ou é feito de forma precária. A forma como ele se relaciona com os demais agentes, e como estes também se inter-relacionam muito depende de como ocorre a contratação comercial. Assim, este coordenador pode estar junto ao empreendedor, fazendo parte de sua equipe interna, pode ser o próprio arquiteto autor do projeto, pode ser um elemento interno à construtora ou, ainda, pode ser um outro agente independente ligado a qualquer um dos três anteriormente mencionados (Figura 49).

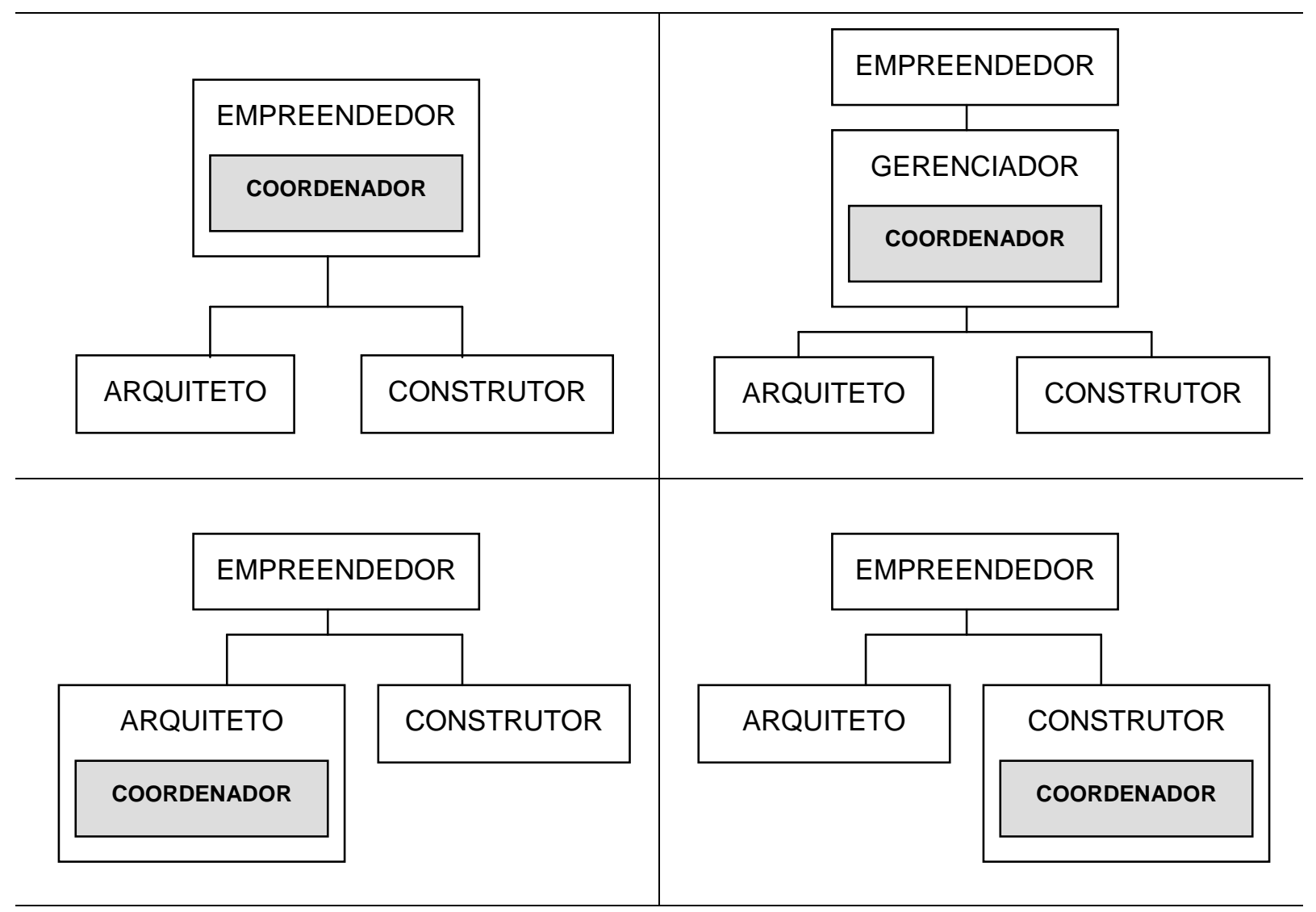

Figura 49 - Diversos arranjos de interação do coordenador de projetos com outros agentes 
A diversidade do posicionamento deste coordenador na interface entre os agentes tem relação com a gradativa perda de autoridade do arquiteto autor do projeto, cujo papel historicamente sempre coincidiu com o papel do coordenador, e esta perda pode ser evidenciada em pesquisas internacionais (RIBA, 1993, GRAY et al., 1994) mencionadas por Grilo (2002) e observada na prática em muitos projetos brasileiros que envolvem certo grau de complexidade. Estas pesquisas atribuem a perda de autoridade a alguns fatores, tais como: falta de diálogo com os clientes, abandono de responsabilidades perante a equipe de projeto e falhas no gerenciamento e controle de custos e prazos. Estes fatores contribuem para a ascendência de construtores e gerenciadores no papel da coordenação das equipes no processo de projeto, dado seu perfil mais acentuado para planejamento e gerenciamento. Além disso, o grau de envolvimento dos diversos agentes varia conforme a etapa do processo (Figura 50), evidenciando, ainda mais, a necessidade de uma figura comum dominando o fluxo de informações destas diferentes etapas.

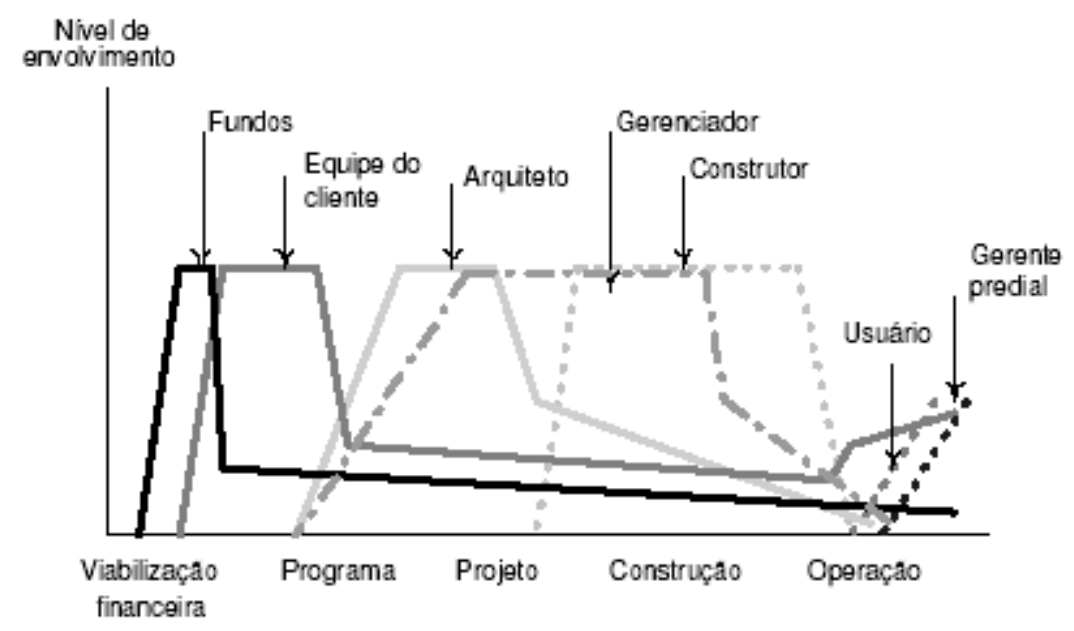

Figura 50 - Envolvimento dos agentes ao longo do processo de um empreendimento

Fonte: Grilo (2002)

De qualquer maneira, o coordenador de projetos, independentemente de sua formação original (arquiteto, engenheiro ou administrador), deve possuir um nível de autonomia que permita o domínio real sobre o planejamento e sobre a gestão do processo de projeto, e as relações comerciais montadas pelo empreendedor devem permitir esta atuação.

O coordenador do projeto não deve ser confundido com o gestor do empreendimento, apesar de ambos apresentarem aptidões comuns, como habilidades pessoais de 
comunicação e de administração do tempo. O primeiro atua somente sobre a coordenação do projeto, que, segundo Melhado (2005),

é uma atividade de suporte ao desenvolvimento do processo do projeto voltada à integração dos requisitos e das decisões de projeto. A coordenação deve ser exercida durante todo o processo de projeto e tem como objetivo fomentar a interatividade na equipe de projeto e melhorar a qualidade dos projetos assim desenvolvidos.

Logo, o coordenador de projetos, para atuar de modo responsável e efetivo, deve possuir não só conhecimentos técnicos acerca dos assuntos sobre os quais irá coordenar, mas também habilidades de administração e liderança de pessoas, para poder gerenciar diferentes equipes de projetos e diversos interesses.

\subsubsection{Custos}

Há algumas naturezas de custos que devem ser consideradas no planejamento do processo do projeto: os custos do processo em si (honorários dos arquitetos, projetistas e consultores, despesas com sistemas de comunicação e aprovações legais), os custos de construção do empreendimento e os custos de operação do edifício em uso, sendo os dois últimos resultantes diretos de decisões técnicas ao longo do processo do projeto.

Morrel (2003) exemplifica que os custos em incorporar, ser proprietário e operar, ao longo de 25 anos, um edifício de escritórios típico para aluguel, no contexto da realidade do Reino Unido, são divididos basicamente em 52\% para criar o negócio (projeto e construção do edifício) e 48\% para a apropriação e operação da edificação, em valores presentes, considerando uma taxa de desconto de 6\% (Figura 51).

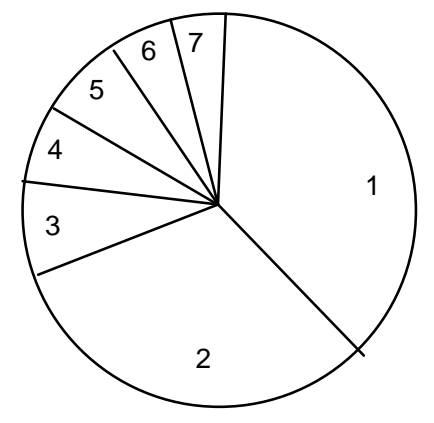

$\begin{array}{lr}1 \text { - Edifício - custo de construção } & 44 \% \\ \text { 2 - Operação e manutenção dos sistemas } & \\ \quad \text { prediais } & 26 \% \\ \text { 3 - Mobiliário - custo do capital } & 8 \% \\ 4 \text { - Edifício - manutenção } & 7 \% \\ \text { 5 - Serviços de limpeza, segurança, etc } & 7 \% \\ \text { 6 - Depreciação dos sistemas prediais } & 5 \% \\ 7 \text { - Manutenção e depreciação do } & \\ \quad \text { mobiliário } & 3 \%\end{array}$

Figura 51 - Perfil de despesas de ocupação de escritórios em 25 anos - sem considerar custos de salários 
Os empreendedores de edifícios de escritórios brasileiros, por considerarem que o negócio imobiliário termina na entrega da obra do edifício, sequer dão importância aos custos de operação, e empregam esforços no sentido de reduzir ao máximo os custos de projeto e de construção. O resultado desta lógica nas decisões de projeto aparece na forma de edifícios dispendiosos em termos de operação, manutenção e consumo de recursos.

\subsubsection{Controle}

Em referência análoga à regra principal do mergulho autônomo técnico, cuja expressão é "plan the dive, and dive the plan", cuja tradução "planeje o mergulho e mergulhe o planejado" (tradução nossa), o planejamento do processo do projeto só faz sentido se houver controle do mesmo. O controle do processo do projeto, bem como suas ferramentas, envolve os mesmos itens de seu planejamento e pressupõe a análise crítica, verificação e validação destes em cada etapa e sub-etapa do processo, fazendo os devidos ajustes e correções de rumo necessários para que o processo e o produto final saiam "conforme planejado" (Figura 52).

Para tanto, este processo de controle envolve a coleta regular de dados para comparar o progresso real do projeto de acordo com o planejado, principalmente relacionado com a avaliação do produto desenvolvido em relação ao programa de necessidades inicial e o cronograma das atividades efetivamente concluídas.

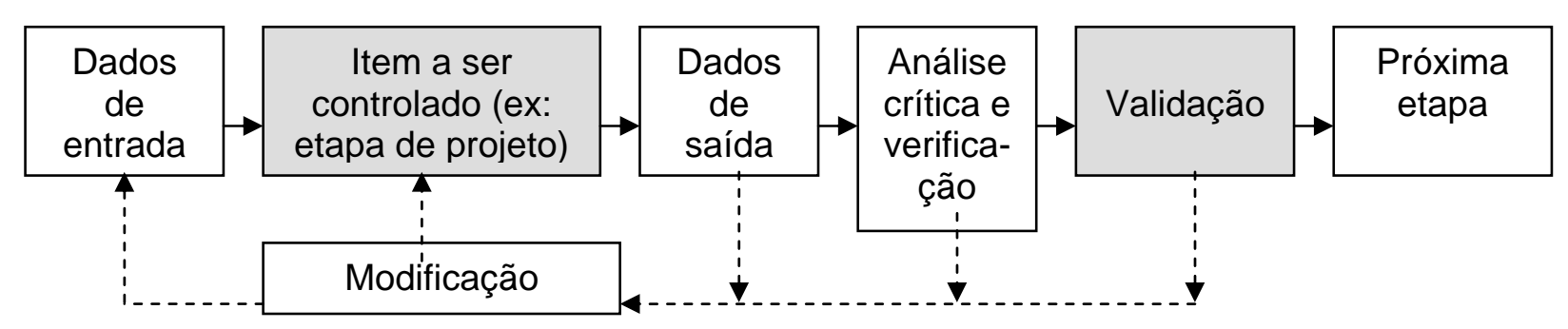

Figura 52 - Diagrama de controle do processo do projeto

Baseado em Melhado et al. (2005) 


\subsection{ETAPAS DO PROCESSO DE PROJETO}

As referências normativas e bibliografias que tratam do desenvolvimento do projeto, em autores como Fabricio (2002), Grilo (2002) e Romano (2003), são unânimes em subdividi-lo em etapas, a começar pela própria norma brasileira NBR 13531 (ABNT, 1995), sendo elas: Levantamento, Programa de Necessidades, Estudo de Viabilidade, Estudo Preliminar, Anteprojeto, Projeto Legal, Projeto Básico e Projeto para Execução. Os diversos autores por eles pesquisados (CTE, 1997; Jobim et al., 1999; Tzortzorpoulos, 1999; ASBEA, 2000; RIBA, 1992; BOBROFF, 1993; SYBEN, 2000) ${ }^{52}$ trazem abordagens semelhantes no que se refere às etapas hierarquizadas e seqüenciais de projeto e às responsabilidades dos agentes ao longo do processo.

Investigando caminhos alternativos à rigidez desta organização seqüencial, Melhado et al. (1996) traz um modelo de processo de projeto cuja subdivisão é voltada à participação e coordenação de esforços dos quatro principais agentes de projeto de um empreendimento de incorporação: projetista de arquitetura, de estrutura, de sistemas prediais e de produção. Neste modelo de processo de participação mais ampla, ocorre a integração do desenvolvimento do projeto com o desenvolvimento do processo de produção do empreendimento, com o enfoque do projeto simultâneo, conceito explorado por Fabricio (2002), no qual representantes dos principais agentes envolvidos participam das equipes de projeto para levar suas expectativas e necessidades ao processo (Figura 53).

Mais recentemente, consoante com essa abordagem, os trabalhos desenvolvidos pelas entidades representativas de projetistas e de contratantes de projetos, que geraram a publicação de onze manuais de escopos de serviços de projetos e de coordenação de projetos da indústria de imobiliária (www.manuaisdeescopo.com.br), definiram seis fases de projeto: concepção do produto, desenvolvimento do produto, solução de interfaces técnicas entre projetos e detalhamento de projetos, pós-entrega de projetos e pós-entrega da obra. A ênfase recai sobre as atividades desenvolvidas em cada fase, e não sobre os produtos de projeto resultantes do seu desenvolvimento.

\footnotetext{
${ }^{52}$ Fabricio (2002) referencia os autores CTE, 1997; Jobim et al., 1999; Tzortzorpoulos, 1999 e ASBEA, 2000. Grilo (2002) referencia os autores RIBA, 1992; Bobroff, 1993 e Syben, 2000.
} 


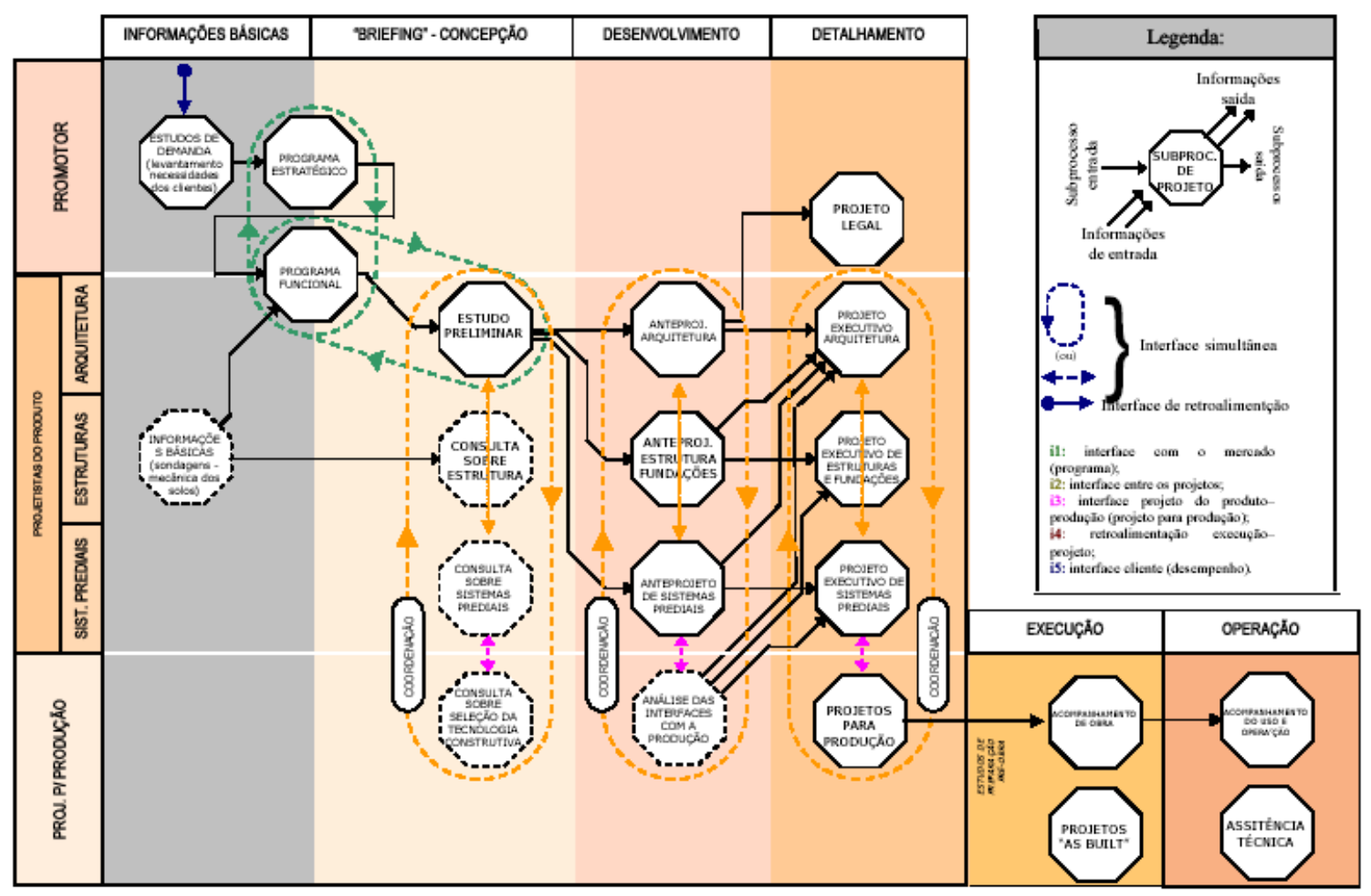

Figura 53 - Modelo genérico para organização do processo do projeto de forma integrada e simultânea Fonte: Fabricio (2002)

Romano (2003), por sua vez, apresenta um modelo de referência para o gerenciamento do processo do projeto integrado de edificações com oito fases: planejamento do empreendimento, projeto informacional, projeto conceitual, projeto preliminar, projeto legal, projeto detalhado (do produto e da produção), acompanhamento de obra e do uso (Figura 54). Este modelo decompõe as fases em atividades e estas, em tarefas, para as quais são modeladas: as informações de entrada, as informações de saída, o domínio de conhecimento, os mecanismos e os controles.

A divisão do processo de projeto em etapas, apesar de apresentar limitações quanto à possibilidade de redução de prazos e em alguns aspectos de integração, mostra-se necessária pela própria natureza do desenvolvimento do projeto e para possibilitar a formalização da evolução do mesmo. Independentemente do modelo adotado, a gestão eficiente e eficaz de um processo de projeto reside na forma como estas etapas são planejadas, executadas e controladas. 


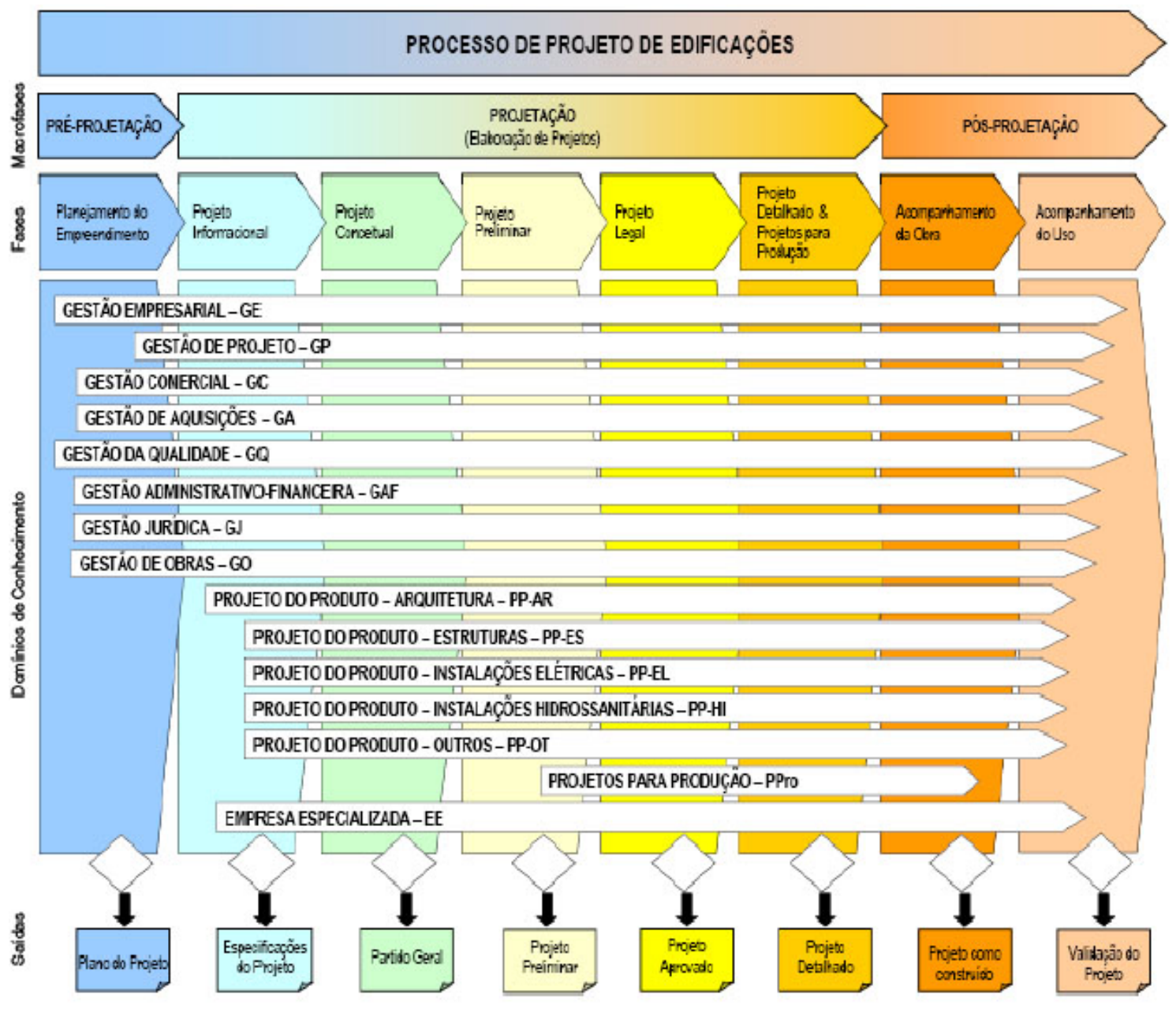

Figura 54 - Representação gráfica dos domínios de conhecimento abordados pela gestão do processo do projeto integrado de edificações

Fonte: Romano (2003) 


\section{OPERAÇÃO E MANUTENÇÃO}

\subsection{INTRODUÇÃO}

Dentro do contexto da gestão do processo do projeto, a fase relacionada a operação e manutenção da edificação pode ser considerada como a última do processo, e a que é afetada pelas decisões tomadas por todas as fases precedentes. A gestão das atividades desta fase faz parte de um outro processo maior, que é o Gerenciamento do Patrimônio Imobiliário (Figura 55), que pode ser desdobrado em outros três processos: Gerenciamento de Propriedades (Property Management), Gerenciamento de Facilidades (Facility Management) e Gerenciamento de Ativos (Asset Management).

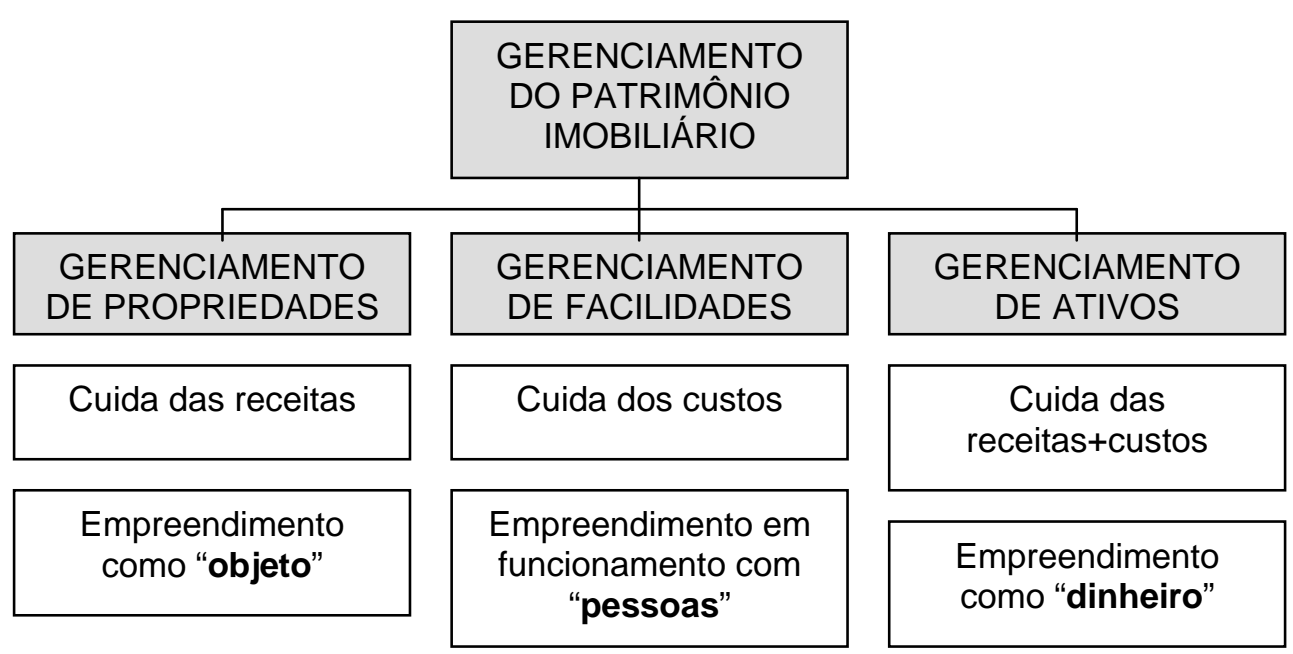

Figura 55 - Desdobramentos do Gerenciamento de Patrimônio Imobiliário

O Gerenciamento de Propriedades é descrito por Rondeau; Brown e Lapides (1995) como a operação e o gerenciamento "rentável" de uma propriedade, que pode ser de uso próprio, locada ou sub-locada, incluindo terreno, edificação, equipamentos e compromissos legais de um proprietário ou empreendedor. O Gerenciamento de Facilidades inclui o suporte ao funcionamento das corporações que ocupam o edifício e é definido por Atkin e Brooks (2009) como "uma abordagem integrada para operação, manutenção, melhoria e adaptação do edifício e da infra-estrutura de uma organização, com o objetivo de criar um ambiente que suporte plenamente os objetivos primários desta organização" (tradução nossa). O 
Gerenciamento de Ativos contempla, de uma maneira geral, os dois processos acima descritos, sem considerar o fator "pessoas".

No caso específico do Gerenciamento de Facilidades, além de visar a integração de propriedades, pessoas e processos, também contempla questões relacionadas à qualidade do ambiente de trabalho, gestão eficiente de recursos não-renováveis (água e energia), gestão do uso de água de fontes alternativas (pluvial e de reuso), e gestão de energia de fontes alternativas (geração própria).

Dependendo do contexto e do tipo de produto imobiliário concebido, a operação e manutenção do empreendimento podem estar relacionadas a qualquer um destes processos. A operação e manutenção de um empreendimento abrangem o funcionamento dos sistemas prediais, tais como: de telecomunicação e informação, automação predial, elevadores, energia, água e condicionamento de ar. Dentro de processos de gerenciamento, seja de propriedades ou de facilidades, serviços como limpeza, manutenção de jardins, segurança, estacionamento, recepção, distribuição de documentos e outros serviços indiretos também estão inclusos nas atividades de operação e manutenção.

O funcionamento eficiente dos sistemas e a facilidade ou não com que estas atividades são executadas influenciam nos custos de operação e manutenção do empreendimento, além de afetar diretamente o estado de conservação do edifício. Segundo Santos, L. S. (2007), em seu trabalho sobre manutenibilidade ${ }^{53}$ em edifícios comerciais,

um edifício com grau de manutenibilidade adequado pode ter seu custo de manutenção reduzido, sendo uma vantagem para o locador, quando exigir menos recursos para sua atualização, contrapartida do investidor.

As características do empreendimento que definem seu grau de manutenibilidade são definidas na fase de projeto, e muitas são conseqüências de definições da fase ainda inicial, de concepção do empreendimento.

53 Manutenibilidade: capacidade de executar uma determinada operação de manutenção sob condições planejadas obtendo resultados efetivos com o mínimo de custos, tempo, perdas, erros e dispêndio (SANTOS, L. S., 2007). 


\subsection{INFLUÊNCIA DA CONCEPÇÃO DOS SISTEMAS PREDIAIS}

Um dos itens que define a atuação e, conseqüentemente, o desempenho alcançado pelas atividades de operação e manutenção, é a concepção do edifício como produto imobiliário e o seu projeto. Martins resume as três principais modalidades de concepção da infraestrutura dos sistemas prediais de um empreendimento para fins comerciais, sob o ponto de vista do empreendedor (informação verbal ${ }^{54}$ ):

- Empreendimento com implantação mínima de infra-estrutura predial: é aquele no qual o empreendedor executa todas as obras civis e implanta a infra-estrutura predial suficiente apenas para o funcionamento das áreas comuns da edificação, ficando a cargo do usuário final a implantação dos sistemas para uso próprio. Ex: unidades, salas ou andares comerciais nos quais os custos de instalação de equipamentos de ar condicionado, distribuição de energia, luminárias e acabamentos são suportados pelos usuários. Este tipo de implantação reduz os custos de investimento inicial do empreendedor e, em contrapartida, oferece menores valores para venda ou locação, quando comparados com as outras modalidades.

- Empreendimento com infra-estrutura predial terceirizada: é aquele concebido para receber a implantação de uma infra-estrutura predial comum completa, sendo a implantação e operação de alguns sistemas feita por uma empresa especializada. Ex: sistemas de co-geração implantados e operados por empresa terceira, que é remunerada por um contrato de fornecimento de energia elétrica. Neste caso, tanto os custos de implantação do sistema quanto o risco de uma eventual inadimplência por parte do usuário são suportados pela empresa fornecedora do sistema, e não pelo empreendedor.

- Empreendimento com infra-estrutura predial para o menor custo operacional: é aquele concebido por empreendedores-proprietários que consideram o ciclo de vida completo da edificação (de 25 a 50 anos) em seu negócio, e que concebem os sistemas prediais de maneira a obter um equilíbrio entre investimento inicial e custo operacional. Desta maneira, os valores de locação podem ser potencializados. Ex: empreendimentos do estudo de caso.

54 Dados obtidos em entrevista concedida pelo eng. Alexandre Ventura Martins, da Hochtief Facility Management do Brasil, em 03 Nov. 2009. 
A modalidade de implantação dos sistemas prediais, definida pelo empreendedor, praticamente determina a forma como a edificação ocupada irá comportar-se em termos de desempenho e eficiência destes sistemas ao longo de seu ciclo de vida. O empreendimento concebido com mínima infra-estrutura predial provavelmente será energeticamente menos eficiente ao longo do tempo do que um similar com sistema de condicionamento de ar central instalado, pois este último fornece "a mesma quantidade de frio" que o conjunto de equipamentos individualizados, com menor consumo de materiais de implantação e energia.

Sob a ótica do usuário de um edifício de escritórios, todos os elementos e sistemas da edificação deveriam ser definidos considerando os menores custos globais. Porém, a própria forma de estruturar o edifício de escritórios como produto imobiliário e as variações possíveis de investimento por parte do empreendedor não permitem a adoção plena desta prática. Aliado a isto, outros motivos possíveis que limitam a utilização da análise de custo global nas tomadas de decisão de projeto, segundo Brown; Hayward e Brown (2003), são:

- A análise de custo global é eficaz para alguns elementos específicos, tais como sistemas de condicionamento de ar e acabamentos em mármore. Fazer a análise de custo global para todos os aspectos do empreendimento gera uma quantidade enorme de fatores a serem considerados, incluindo a interação entre diferentes elementos;

- A análise de custo global funciona melhor como diretriz para um valor mais adequado do que para um custo exato;

- O nível de informações disponíveis sobre o comportamento dos materiais, em longo prazo, é incompleto;

- Diferentes usuários têm diferentes políticas contábeis, sendo assim, em alguns casos, pode ser mais interessante para o usuário ter custos de operação mais elevados e menor desembolso de capital;

- Para o proprietário ou locatário, cada usuário tem uma maneira diferente de usar o edifício, praticamente impossível de prever;

- A forma de ocupação dos empreendimentos está mudando em uma velocidade crescente, o que diminui a efetividade de uma análise de custo global.

Outro item importante que dificulta a operação e manutenção do empreendimento está no fato do agente responsável por esta fase do processo de projeto raramente ter contato ou influência sobre as fases precedentes, principalmente a fase de concepção do produto. Em função disto, muitos edifícios de escritórios apresentam projetos elegantes e até energeticamente balanceados, porém com dificuldades logísticas de operação (ex: centrais de utilidades distantes umas das outras, como central de água gelada distante da central de 
energia e da torre de resfriamento) e de manutenção (ex: ausência de sistema para limpeza de fachadas ou fachadas que não permitem seu acesso para limpeza). O entendimento do mercado quanto a sistemas prediais que têm operação muito complexa resulta em dois quadros muito comuns: ou a operação não é feita conforme o projeto, ou é feita de modo inadequado, resultando em perda de eficiência de funcionamento do sistema e redução de sua vida útil. 


\subsection{RETROALIMENTAÇÃO}

\subsubsection{Dados dos usuários}

Dentro do universo do Gerenciamento do Patrimônio Imobiliário, o Gerenciamento de Facilidades é o processo no qual há envolvimento dos usuários do empreendimento, e do qual é possível extrair informações valiosas de retroalimentação a respeito de suas necessidades.

Em edifícios de escritórios, sabe-se que os ambientes de trabalho influenciam na produtividade dos usuários, tanto de modo positivo, quanto negativo, porém, o assunto torna-se mais complexo quando se tenta trabalhar com dados quantitativos para medir a produtividade em si e qual o fator do ambiente que mais pesa sobre ela. Além disso, Brown; Hayward e Brown (2003) comentam que muitos usuários não sabem de fato o que necessitam, nem entendem quanto o projeto de um edifício pode afetar seus negócios principais.

Segundo estes autores, as principais fontes de informação utilizadas por empresas de Gerenciamento de Facilidades do Reino Unido para entender melhor estas necessidades são as Centrais de Ajuda (Help Desks), os Diários de Uso (Logbooks), os representantes dos usuários (occupier's staff) e as avaliações de pós-ocupação. As duas primeiras fontes estão relacionadas à forma pela qual o gerenciamento é feito pelas empresas daquele país, na qual as ocorrências do dia-a-dia são registradas pelas centrais, permitindo que eventuais recorrências mostrem como está acontecendo a interação do negócio do usuário com a edificação; e onde todo o funcionamento do edifício também é registrado (ex: horários de partida e desligamento dos sistemas de ar condicionado, horários de entrada e saída das pessoas, planos de manutenção de sistemas, etc), sejam de forma manual ou eletrônica. As informações dos representantes dos usuários (que interagem diretamente com a empresa de gerenciamento) e das avaliações de pós-ocupação já são utilizadas para a realidade brasileira, sendo que uma proposta de metodologia para este tipo de avaliação, de Ornstein; Roméro (1992), já está disponível há mais de quinze anos.

O entendimento das necessidades dos usuários permite que dados do Gerenciamento de Facilidades possam ser utilizados para completar e melhorar o programa de necessidades de projetos novos ou de reformas de edifício de escritórios. Graça (informação verbal ${ }^{55}$ )

\footnotetext{
${ }^{55}$ Dados obtidos em entrevista concedida pelo prof. Moacyr E. Alves da Graça, em 07 Dez. 2009.
} 
exemplifica o caso de um projeto do qual participou, em que um grupo empresarial desejava reunir suas diversas empresas em uma nova sede, cujo plano de consolidação de facilidades foi resultado da análise de questionários estruturados aplicados a diversos grupos de trabalho (diretoria e colaboradores). O programa de necessidades do projeto foi resultado deste processo, que, entre outros itens, apontou a necessidade comum por espaços de treinamento e eventos, necessidade esta identificada na análise dos questionários e que não havia aparecido no programa de necessidades inicial elaborado pelos representantes do grupo empresarial.

\subsubsection{Dados para projeto}

A importância de se considerar as atividades de operação e manutenção dos empreendimentos, ainda em projeto, confere a possibilidade de diminuir o grau de incerteza sobre as despesas destas ao longo do tempo. Segundo Santos, L. S. (2007):

Se as despesas com manutenção ficam dentro das metas estabelecidas para o empreendimento, dificilmente deixarão de ser realizadas, gerando benefícios para os usuários do edifício, que contam com instalações conservadas, e também para os investidores que podem contar uma maior vida útil para o empreendimento e menor taxa de vacância ${ }^{56}$.

Uma análise sobre pesquisa de levantamento de dados com responsáveis pela operação de edifícios comerciais, feita por Santos, L. S. (2007), apontou os seguintes temas mais recorrentes a respeito de dificuldades para operação e manutenção de edifícios e que estão intrinsecamente ligados às definições e especificações de projetos:

- Acesso: dificuldades para acesso a fachadas e coberturas para realização de limpeza e reparos (troca de vidros, manutenção de juntas de vedação, acesso à cobertura) e dificuldades para acesso a equipamentos, caixas de inspeção e dutos do sistema do ar condicionado;

- Especificação de materiais: especificação de revestimentos ou equipamentos inadequados às condições de uso. Ex: revestimentos pouco resistentes ou que requerem procedimentos de limpeza especiais, condições estéticas de escadas, sistemas elétricos em desacordo com as normas brasileiras;

56 Índice utilizado para medir o desempenho do mercado imobiliário. Refere-se à porcentagem do espaço vago (pronto e não ocupado) em relação ao espaço total disponível no mercado. 
- Subdimensionamento: problemas com sistema de drenagem de águas pluviais, dimensão inadequada de casas de máquinas de ar condicionado, incidência de recalque diferencial das fundações;

- Infra-estrutura: ausência de pontos de água para limpeza e manutenção (principalmente em casa de máquinas de ar condicionado, para limpeza das serpentinas), ausência de monitoramento das condições dos sistemas, deficiência de áreas de apoio para a equipe de operação do edifício, falta de caixas de inspeção ao longo das instalações, ausência de sistemas de irrigação, ausência de pontos elétricos e circuitos adequados para equipamentos de manutenção;

- Informação: ausência de identificação física de sistemas e equipamentos, indisponibilidade de projetos para consulta e diagnóstico de problemas, insuficiência de informações sobre especificações e procedimentos de manutenção dos sistemas incorporados ao edifício;

- Reposição: indisponibilidade de peças de reposição (por descontinuidade de produção ou aquisição de lotes específicos de produtos importados), ausência de estoque de reposição;

- Flexibilidade: ausência de espaço físico para atualização, melhoria e expansão dos sistemas, número insuficiente de válvulas seccionadoras hidráulicas (o que compromete a operação do edifício como um todo durante uma manutenção);

- Estanqueidade: problemas oriundos de deficiência de vedação de elementos de fachada e dos subsolos.

Além destes temas, outros itens de projeto que podem facilitar as atividades de operação e manutenção e que devem ser equacionados dentro do universo de interesses entre empreendedores, projetistas e administradores prediais, são listados abaixo:

- Logística do funcionamento dos sistemas prediais. Ex: em um edifício de escritórios com sistema de ar condicionado que prevê a existência de central de água gelada e torre de resfriamento, é mais conveniente, do ponto de vista operacional, que estes dois subsistemas estejam próximos entre si e próximos aos alimentadores elétricos principais (entrada ou subestação);

- Previsão de espaços adequados, dentro da edificação, para as equipes de operação e manutenção;

- Na automação predial, possibilidade de operação independente das funções dos sistemas, por área de atuação: segurança pessoal, segurança patrimonial, energia, etc, de modo a otimizar a atuação das equipes especializadas de cada área; 
- Previsão de acesso ou sistema para limpeza e manutenção das fachadas. Existem gôndolas próprias para este tipo de serviço, mas a estrutura de fixação destas deve estar já prevista em projeto, pois uma eventual implantação posterior em um empreendimento, sem esta previsão, pode não ser possível. Além disso, se houver brises na fachada, estes também devem ter acesso para limpeza e eventual troca;

- Em empreendimentos de múltiplas torres ou que envolvam uma população relativamente grande, previsão de acesso e vaga coberta para ambulância, considerando que esta tem altura diferenciada em relação a automóveis de passeio (todo o percurso feito pela ambulância deve ter pé direito adequado, e não só o local onde ela fica estacionada). 


\section{TECNOLOGIA DA INFORMAÇÃO}

\subsection{INTRODUÇÃO}

O termo tecnologia da informação (TI), ou tecnologia da informação e comunicação (TIC) serve para designar o conjunto de recursos tecnológicos e computacionais para geração e uso da informação. A crescente evolução destes recursos exerce forte influência nos requisitos de configuração dos ambientes de escritórios (aspectos explorados por ANDRADE, 2007 e DUFFY, 1999), nas necessidades de infra-estrutura dos sistemas prediais dos edifícios (DE MARTINI, 2008), nos sistemas que compõem o "edifício inteligente", no desenvolvimento do processo do projeto e também na sua gestão. Segundo Florio (2006), a TIC tem sido usada para racionalizar, desenvolver processos e gerir dados da construção de edifícios, especialmente aqueles com maior complexidade formal-espacial. Dentro do contexto da geração e do fluxo de informações na gestão do processo de projetos, destacam-se os softwares de cálculo e modelagem tridimensional (ferramentas $B I M^{57}$ ), e as extranets de projeto, sistemas que permitem o compartilhamento de bases de dados digitais entre diferentes agentes.

\subsubsection{Ferramentas de cálculo e modelagem tridimensional}

Os softwares de cálculo e modelagem tridimensional são uma tentativa de convergência entre várias ferramentas utilizadas para conceituar e detalhar um projeto de edifício no ambiente virtual. No contexto atual de muitos processos de projeto brasileiros, os projetos de edificações das diversas disciplinas utilizam-se das ferramentas computacionais apenas como substitutos de ferramentas manuais (uso de programas $C A D D^{58}$ para desenhos como prancheta eletrônica; uso de e-mails para correspondência ao invés de cartas em papel).

Para exemplificar o funcionamento das ferramentas CADD como mera prancheta eletrônica, os projetistas recebem uma base (um arquivo) digital comum arquitetônica, bidimensional, e desenvolvem seus próprios projetos de maneira independente e estanque (diversos

\footnotetext{
${ }^{57}$ Building Information Modeling.

${ }^{58}$ Computer Aided Design and Drafting.
} 
arquivos digitais, um para cada disciplina), para depois terem as eventuais interferências avaliadas, usualmente em papel. Esta forma de atuar (Figura 56) apresenta ganho relativo de tempo nas revisões de desenhos, mas não altera significativamente a eficácia da gestão do projeto em seu processo como um todo.

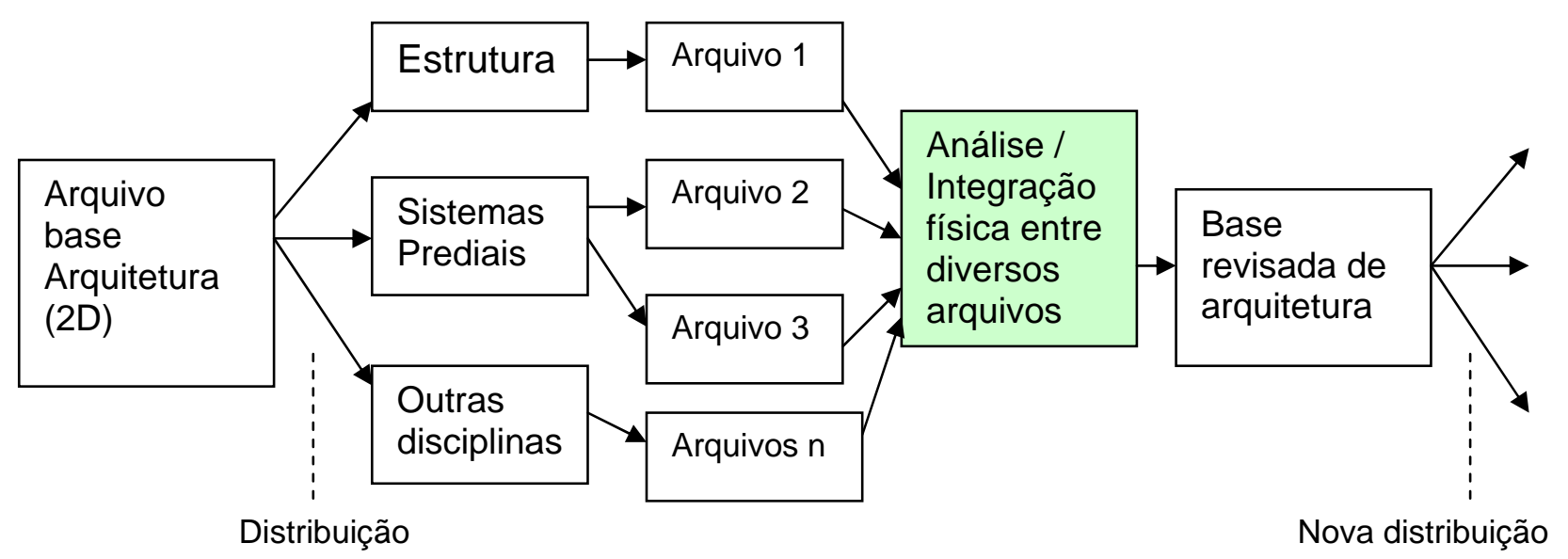

Figura 56 - Uso estanque das ferramentas digitais de projeto

Os softwares de modelagem tridimensionais (ou modelagem 3D), disponíveis e utilizados pela indústria aeronáutica e petroquímica, fazem esta convergência entre disciplinas, de forma que todas trabalhem sobre o mesmo modelo digital, codificado para descrever e representar componentes do produto projetado, podendo ser um edifício ou uma aeronave (Figura 57). Esta ferramenta de modelagem virtual, composta por um banco de dados que permite agregar informações para diversas finalidades, é um dos pontos que compõem o BIM (CRESPO; RUSCHEL, 2007).

Esta ferramenta já está acessível comercialmente devido aos avanços da tecnologia computacional, mas existem diversas dificuldades para sua adaptação no uso de projetos de edificações, entre elas: pouca integração da ferramenta de modelagem em relação aos softwares de desenho e cálculo atualmente utilizados; alto investimento requerido para aquisição da ferramenta e treinamento dos funcionários; riscos deste investimento, uma vez que o setor de projetos e construção brasileiro é fragmentado e não há garantias de que todos os agentes da cadeia produtiva terão a mesma ferramenta para troca de informações; e falta de base de dados das ferramentas para o contexto de edificações e de tecnologias construtivas nacionais. 


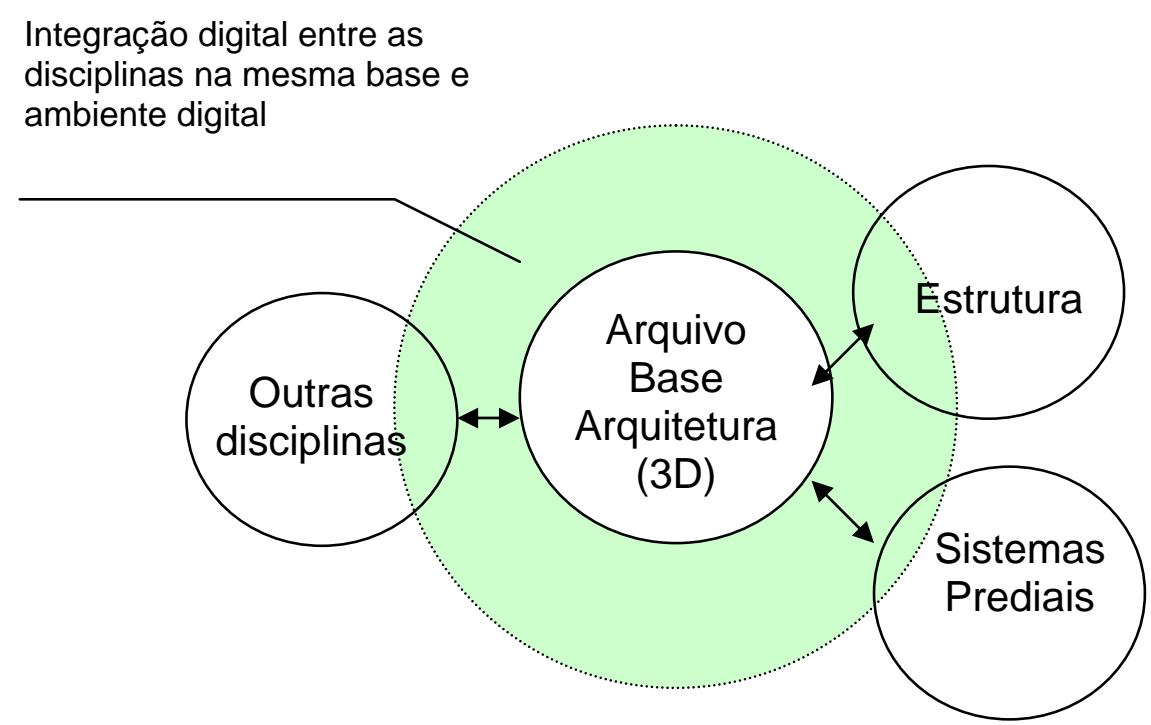

Figura 57 - Uso integrado de ferramentas tridimensionais de projeto

As ferramentas BIM permitem que o processo do projeto seja feito de forma colaborativa, em que "toda a equipe decide em conjunto, co-participa das decisões e da condução do processo, sem centralizar demasiadamente as decisões em um ou outro parceiro de projeto" (FLORIO, 2007). Contudo, a dificuldade em se fazer mudanças na metodologia de trabalho das empresas de projeto para que o processo colaborativo seja efetivamente utilizado, aliada às demais dificuldades já citadas para adaptação do uso das ferramentas BIM disponíveis, acaba justificando a baixa adesão atual ao seu uso.

Mesmo com estas dificuldades, entende-se que um dos aspectos para a evolução do processo do projeto e sua respectiva ligação com a execução da obra esteja atrelado ao uso deste tipo de ferramenta, pois a integração dos fatores tempo e custo, em um projeto modelado pela BIM, permite a simulação das etapas de sua construção ainda no ambiente virtual, o que pode trazer grandes vantagens em termos de planejamento do empreendimento como um todo.

\subsubsection{Extranets}

As extranets de projeto são websites, criados e mantidos por empresas especializadas, que controlam o acesso às informações do ambiente da internet por meio de protocolos de autorizações. De acordo com Manzione (2006), uma extranet de projeto lida com a informação eletrônica através do armazenamento centralizado de dados e a manutenção de 
um ambiente de trabalho em rede, que permite aos usuários acesso às informações armazenadas, possibilitando o acompanhamento do seu processo de trabalho. Desta forma, a troca intensiva de informações entre equipes de projeto e agentes do processo, fisicamente distantes entre si, é facilitada (Figura 58).

Ainda segundo pesquisa exploratória conduzida por Manzione (2006), a situação atual mostra que as extranets, apesar de importantes como ferramentas, não atingiram ainda uma maturidade tecnológica suficiente para solucionar as questões relacionadas à gestão do processo do projeto, pois têm enfoque maior no gerenciamento de documentos, e pouco ou nenhum no gerenciamento das comunicações e no gerenciamento do workflow (processo de trabalho). As poucas ferramentas que têm atuação nestes dois últimos itens limitam de tal forma a condução do processo, que muitos empreendedores desistiram de utilizá-las.

Acredita-se, porém, que é possível desenvolver alternativas de solução para estas dificuldades, dependendo do nível de demanda e da disposição dos fabricantes de softwares. Uma eventual evolução das ferramentas, tanto das extranets quanto das de cálculo e modelagem tridimensional, poderá influenciar em mudanças significativas no processo de gestão do projeto de edificações, e provavelmente na gestão do empreendimento como um todo.

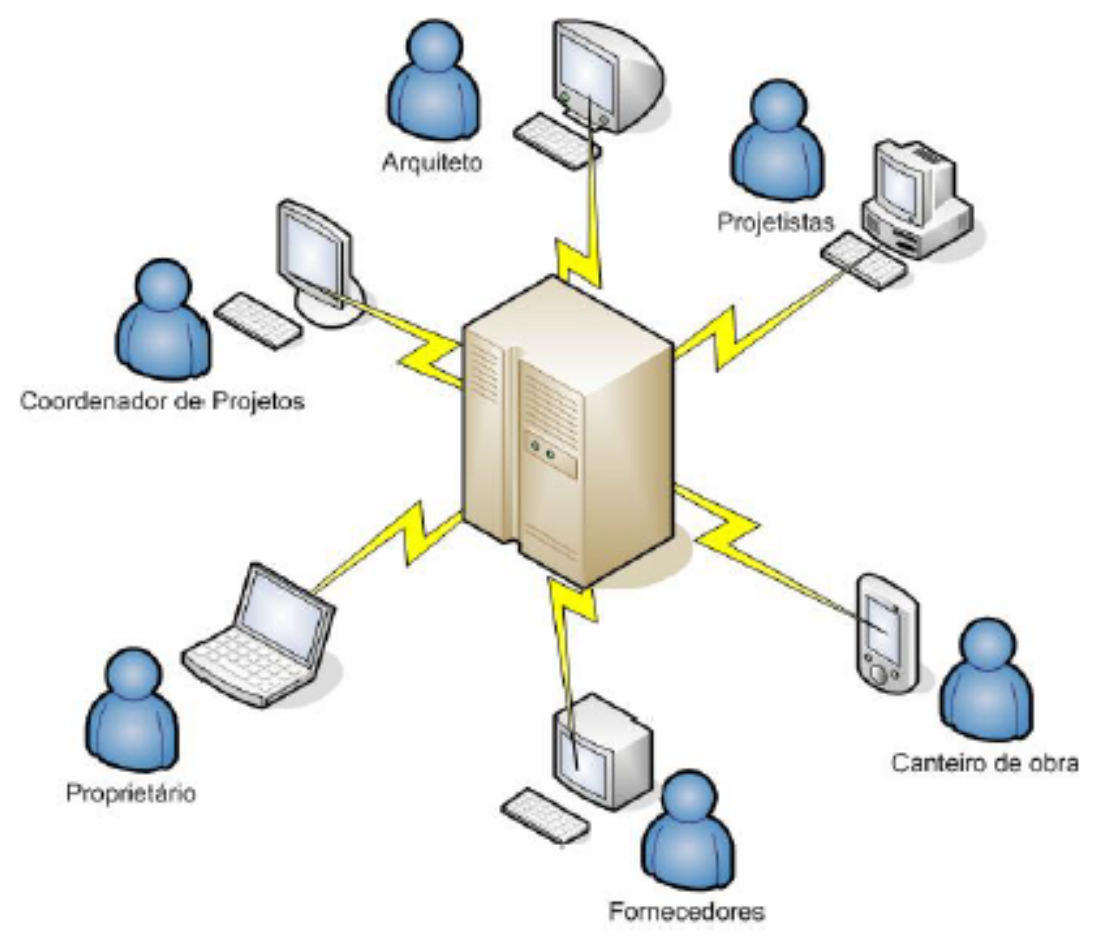

Figura 58 - Comunicação em um empreendimento com extranet de projeto Fonte: Nascimento (2004) 


\section{SUSTENTABILIDADE}

\subsection{INTRODUÇÃO}

Esta seção relaciona a importância do tema sustentabilidade com o ciclo de vida da edificação - e consequentemente com o projeto -, abordando conceitos de construção sustentável e "edifícios verdes" (green buildings), e identificando modelos de avaliação de desempenho de empreendimentos disponíveis no Brasil. Os aspectos técnicos de soluções relacionadas a este tema, quando pertinentes, estão apresentados dentro de cada especialidade de projeto (capítulo B). Exemplo: aspectos sobre o ar condicionado na construção sustentável de edifícios de escritório estão abordados em seção específica dos Sistemas Prediais.

\subsubsection{Definições}

Sustentabilidade é um conceito em evolução e multidisciplinar. De modo genérico, pode-se adotar a seguinte definição:

Sustentabilidade é um conceito sistêmico, relacionado com a continuidade dos aspectos econômicos, sociais, culturais e ambientais da sociedade humana. Propõe-se a ser um meio de configurar a civilização e atividades humanas, de tal forma que, a sociedade, os seus membros e as suas economias possam preencher as suas necessidades e expressar o seu maior potencial no presente, e ao mesmo tempo preservar a biodiversidade e os ecossistemas naturais, planejando e agindo de forma a atingir pró-eficiência na manutenção indefinida desses ideais (WIKIMEDIA FOUNDATION, 2008).

O termo de origem, ainda segundo a Wikimedia Foundation (2008), foi "desenvolvimento sustentável", que, segundo a CMMAD ${ }^{59}$ da Organização das Nações Unidas, é "aquele que atende às necessidades presentes sem comprometer a possibilidade de que as gerações futuras satisfaçam as suas próprias necessidades". Esta é a mesma definição feita no relatório de Brundtland de 1987.

\footnotetext{
${ }^{59}$ Comissão Mundial sobre Meio Ambiente e Desenvolvimento.
} 
O reconhecido tripé em que se baseia o desenvolvimento sustentável (Figura 59) surgiu na Declaração de Política de 2002 da Cúpula Mundial sobre Desenvolvimento Sustentável, realizada em Joanesburgo, que afirma que o mesmo é construído sobre "três pilares interdependentes e mutuamente sustentadores" - desenvolvimento econômico, desenvolvimento social e proteção ambiental.

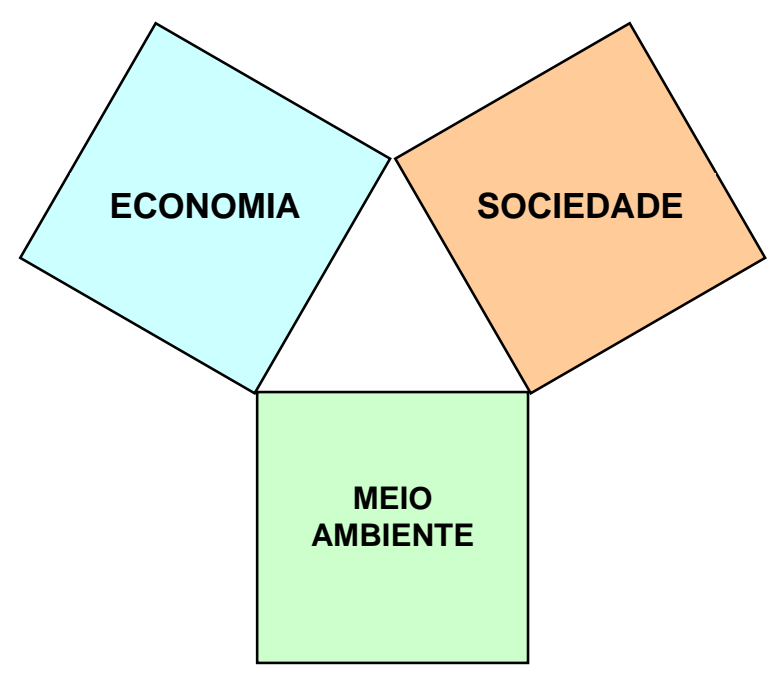

Figura 59 - Pilares do desenvolvimento sustentável

\subsubsection{A construção sustentável}

Cabral (2007) afirma que "o conceito de construção sustentável surgiu pela primeira vez com a crise do petróleo nos anos 70 , quando os altos preços da energia levaram à busca por sistemas alternativos e mais baratos (...)". Por este mesmo motivo, os primeiros edifícios projetados com esta preocupação foram os de países onde a matriz energética dependia em grande parte da geração de termelétricas, tais como Alemanha, Holanda e norte da Europa. Mas, as primeiras medidas mais consequentes relacionadas ao tema são da década de 90 , com estudos mais sistemáticos e resultados mensuráveis, como reciclagem de materiais e redução de perdas e energia. Mais recentemente, os aspectos relacionados às condições sociais, econômicas e culturais do ambiente construído passaram a ser considerados na construção sustentável.

As definições e diretrizes de construção sustentável estão mais bem conceituadas no texto da Agenda 21 para Construção Sustentável (2000). Este texto é uma sistematização de todos os estudos do $C I B^{60}$ sobre o tema, realizados nas duas últimas décadas do século $\mathrm{XX}$, com ênfase nos últimos cinco anos. O CIB, por sua vez, é uma organização internacional

$\overline{60}$ International Council for Research and Innovation in Building and Construction. 
líder de pesquisa em construção. Os objetivos do texto da Agenda 21 que, na época, eram: (1) servir de alerta para todos os setores da Indústria da Construção Civil sobre os problemas ambientais com que interagem e (2) servir de orientação para formulação de diretrizes, políticas, normativas e soluções a fim de tornar as atividades destes setores ambientalmente mais favoráveis, pretendendo chegar à construção sustentável, continuam, nove anos depois, notadamente atuais.

Ainda no texto da Agenda 21 (2000), construção sustentável é definida por Kibert como "a criação e a administração responsável de um meio ambiente de construção saudável, fundamentados em princípios ecológicos e recursos eficazes". Esta primeira definição serviu como diretriz para outros enfoques, tais como os da Finlândia, onde a construção sustentável, de acordo com a definição, "em seu processo e produto característicos durante sua vida útil, visa minimizar o uso da energia bem com minimizar as emissões que sejam danosas para o meio ambiente e para a saúde e produz informações relevantes para a tomada de decisão de seus clientes". Nos Países Baixos, a definição oficial de construção sustentável é "um modo de construir que visa a redução (negativa) do impacto sobre a saúde e o meio ambiente causado pelo processo de construção ou por edifícios ou pelo ambiente". Finalizando, o texto aponta que uma definição mais precisa do que seja construção sustentável: "a redução do uso de recursos naturais e a conservação da função que suporta a vida do meio ambiente, por meio de processos construtivos, edifícios e do ambiente construído sob a premissa de que a qualidade de vida será mantida".

O conceito de construção sustentável, cada vez mais atual em função das discussões em torno do aquecimento global do planeta e das mudanças climáticas, deve ser entendido como uma demanda a ser considerada em todos os projetos, por estar gradativamente mais presente em leis, normas e métodos de avaliação das edificações, com consequências para toda a cadeia produtiva da indústria da construção civil, cujos dados relativos a consumo de insumos e energia, comparados com as demais atividades industriais e de serviços, justifica a crescente preocupação sobre o tema.

\subsubsection{Dados de consumo da indústria da construção}

Segundo o texto da Agenda 21 (2000), apesar de o número variar de país para país, os edifícios são responsáveis diretos por cerca de $30 \%$ do consumo total da energia, e por algo perto dos $50 \%$, se o uso indireto for considerado. As construções na União Européia são responsáveis por mais de $40 \%$ do consumo total de energia e estima-se que o setor da 
construção gere aproximadamente $40 \%$ de todo o lixo produzido pelo homem. O setor da construção é o maior setor industrial da União Européia, contribuindo com aproximadamente $11 \%$ do PIB e empregando mais de 25 milhões de pessoas, direta ou indiretamente. Nos Estados Unidos, segundo Cabral (2007), os prédios comerciais consomem 65\% da energia elétrica distribuída no país, sendo que a metade é consumida pelo ar-condicionado. No Brasil, esse índice é de cerca de 50\%. Por este motivo, uma das principais premissas em um projeto de construção sustentável de edificações refere-se ao seu consumo energético. 


\subsection{EDIFÍCIOS VERDES}

Uma forma encontrada para responder em parte aos desafios gerados pela crescente escassez e encarecimento dos recursos naturais apresenta-se com os chamados "edifícios verdes". No jargão comercial, "green buildings", cuja definição pode ser:

Green building é a prática de melhorar a eficiência com a qual os edifícios consomem recursos - energia, água e materiais - reduzindo impactos na saúde humana e do meio ambiente, por meio de melhor implantação" (WIKIMEDIA FOUNDATION, 2008 - tradução nossa).

$\mathrm{Na}$ mesma linha, o World Green Building Council ${ }^{61}$ (2008) define, pelas premissas de avaliação para fins de certificação, que um edifício verde é um projeto ambientalmente responsável, lucrativo, e um local saudável para viver e trabalhar. Nesta linha, encontram-se manuais específicos de projeto para desenvolvimento de edifícios verdes, sob a ótica norteamericana, de autores tais como Frej et al. (2005) e Mendler; Odell e Lazarus (2000).

Eubank (2008) considera que há uma diferenciação entre os termos edifício verde e edifício sustentável (Figura 60). O edifício verde concentra sua abordagem nas questões ambientais e é aquele que, por diversas características de projeto e de construção, tem um desempenho melhor de consumo de recursos naturais (notadamente água e energia) do que um edifício tradicional. Há também a preocupação com a qualidade do ambiente construído (qualidade do ar, confortos térmico, acústico, luminoso e ergonômico) e com a construção em si (redução da geração de resíduos, utilização de materiais recicláveis). Assim, o limite de desempenho de um edifício verde é a capacidade de "zerar" o impacto provocado pelo consumo de recursos para sua construção e operação. Por este raciocínio, se o edifício é capaz de gerar, por si só, toda a energia elétrica que consome, pode ser considerado como um edifício de consumo energético zero ${ }^{62}$.

Já o edifício sustentável, além de ultrapassar o consumo zero, deve ajudar a "restaurar" ou retornar algo útil ao meio ambiente, seja na forma de carbono capturado, ar e água filtrados, ou excedente de energia, para ser distribuído à comunidade do entorno. O termo "sustentável" indica que mais questões devem ser abordadas (sociais inclusive), além do simples consumo e devolução de recursos.

\footnotetext{
${ }^{61}$ WGBC (www.worldgbc.org).

62 net-zero energy.
} 


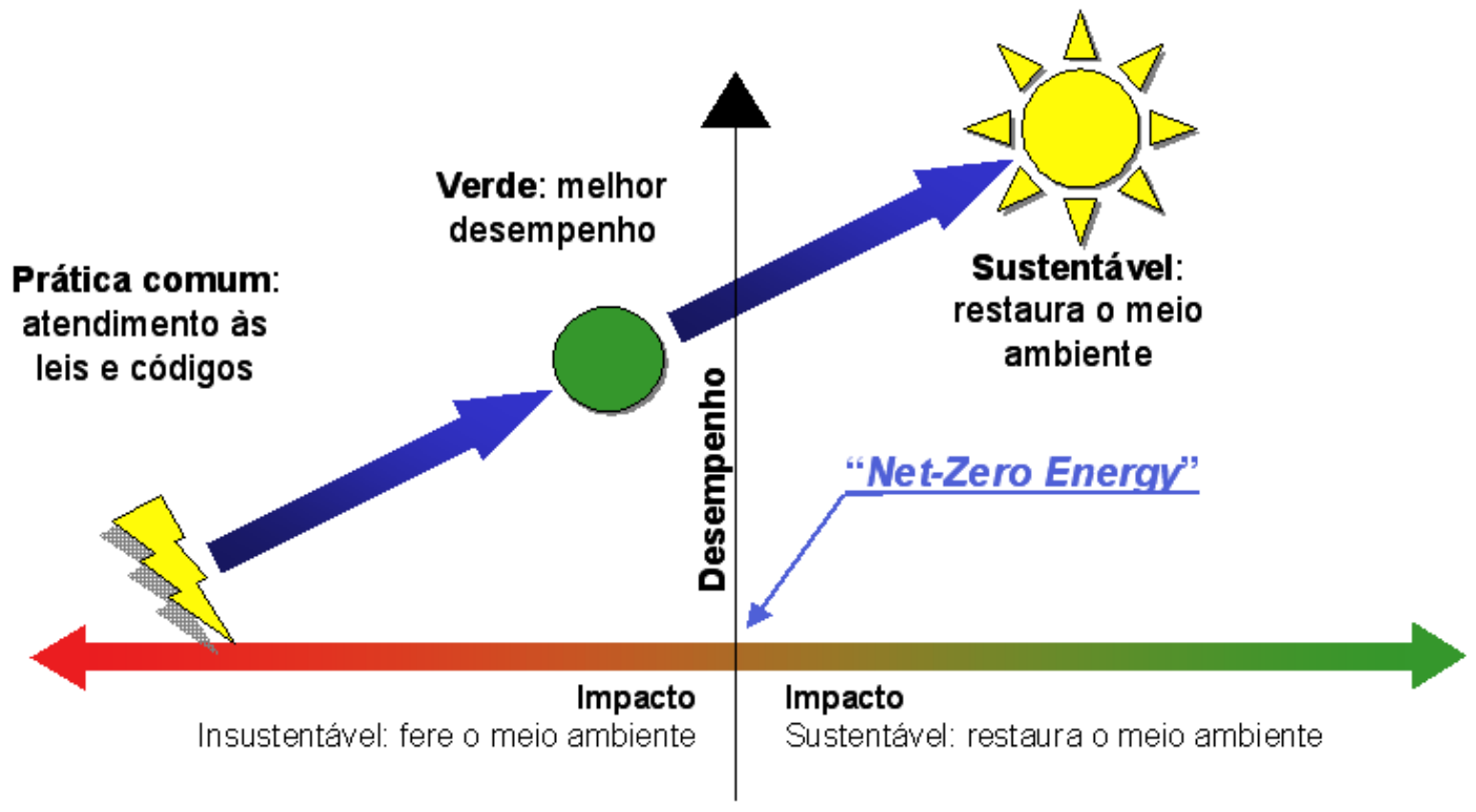

Figura 60 - Escala de impacto dos desempenhos de edifícios

Fonte: Eubank (2008)

Yeang (2006), reconhecido por seus projetos que respeitam as condições bioclimáticas de onde se situam, considera que os projetos dos edifícios englobam aspectos de integração, do entorno urbano e até da biosfera, e prefere o termo projeto ecológico (ecodesign). Ele atesta que:

Muitos arquitetos acreditam erroneamente que, se encherem um edifício com aparelhagens ecológicas, tais como: coletores solares, geradores eólicos, fotovoltagem e biodigestores, então eles instantaneamente terão um projeto ecológico (tradução nossa).

Um exemplo deste tipo pode ser visto no projeto do Pearl River Tower, do escritório de arquitetura americano SOM (Skidmore, Owings \& Merrill), cuja implantação se dá em Guangdzou, China. Entre outros atributos, o edifício está projetado para ser classificado como "net-zero energy", uma vez que ele produzirá toda a energia que consumirá, por meio de geração eólica (Figura 61) e fotovoltáica.

Contudo, por mais que o edifício seja auto-suficiente na questão de consumo de recursos (seja de água ou energia), é difícil pensar que em um empreendimento com 71 andares (310m) e ainda por cima, sede de uma companhia de tabaco (Guangdong Tobacco Company), seja sustentável. Mesmo considerando que os maiores gastos do edifício no seu ciclo de vida ocorram na fase de uso e operação, o impacto de concentração e mobilidade da população dele e de seu entorno, além das condições sociais dos trabalhadores que irão construí-lo, aparentemente não estão tão bem resolvidos como a questão energética. 

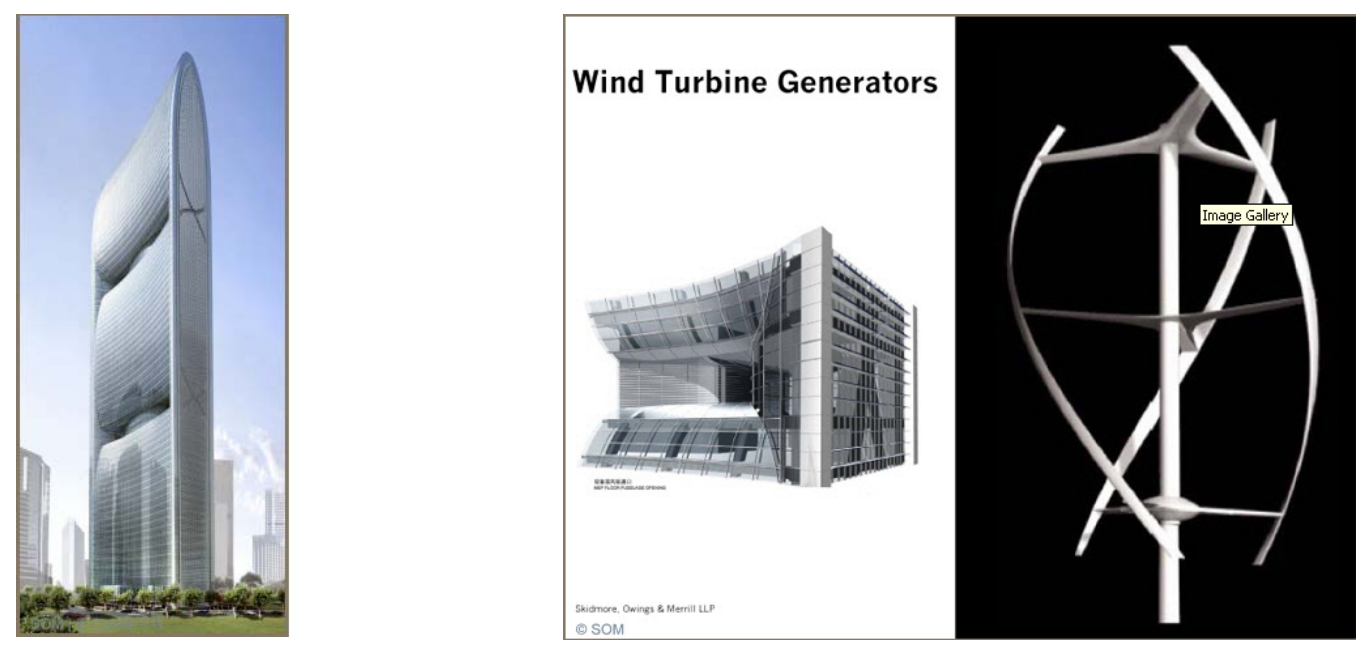

Figura 61 - Projeto do Pearl River Tower e detalhe das turbinas eólicas

Fonte: www.som.com

Yeang (2006), contudo, não descarta a abordagem do uso dos sistemas prediais como aliados ao projeto ecológico. Ele considera que esta abordagem é uma das ferramentas que podem ser utilizadas neste tipo de projeto. O objetivo maior do projeto ecológico refere-se à integração harmônica entre o ambiente construído e o ambiente natural. 


\subsection{O CICLO DE VIDA DA EDIFICAÇÃO SOB A ÓTICA DO EMPREENDEDOR}

Pelo ponto de vista do empreendedor de um edifício de escritórios como produto imobiliário, o ciclo de vida dele inicia-se com a sua idealização e concepção (fase de viabilidade e projeto), construção, eventualmente operação e manutenção, e finalmente renovação (adaptação para reuso, ou retrofit). Segundo dados apresentados por Ceotto (2008), no custo total de um empreendimento, considerando um ciclo de vida de 50 anos, a parcela de maior proporção de gastos é relativa ao uso e operação do edifício (Figura 62).

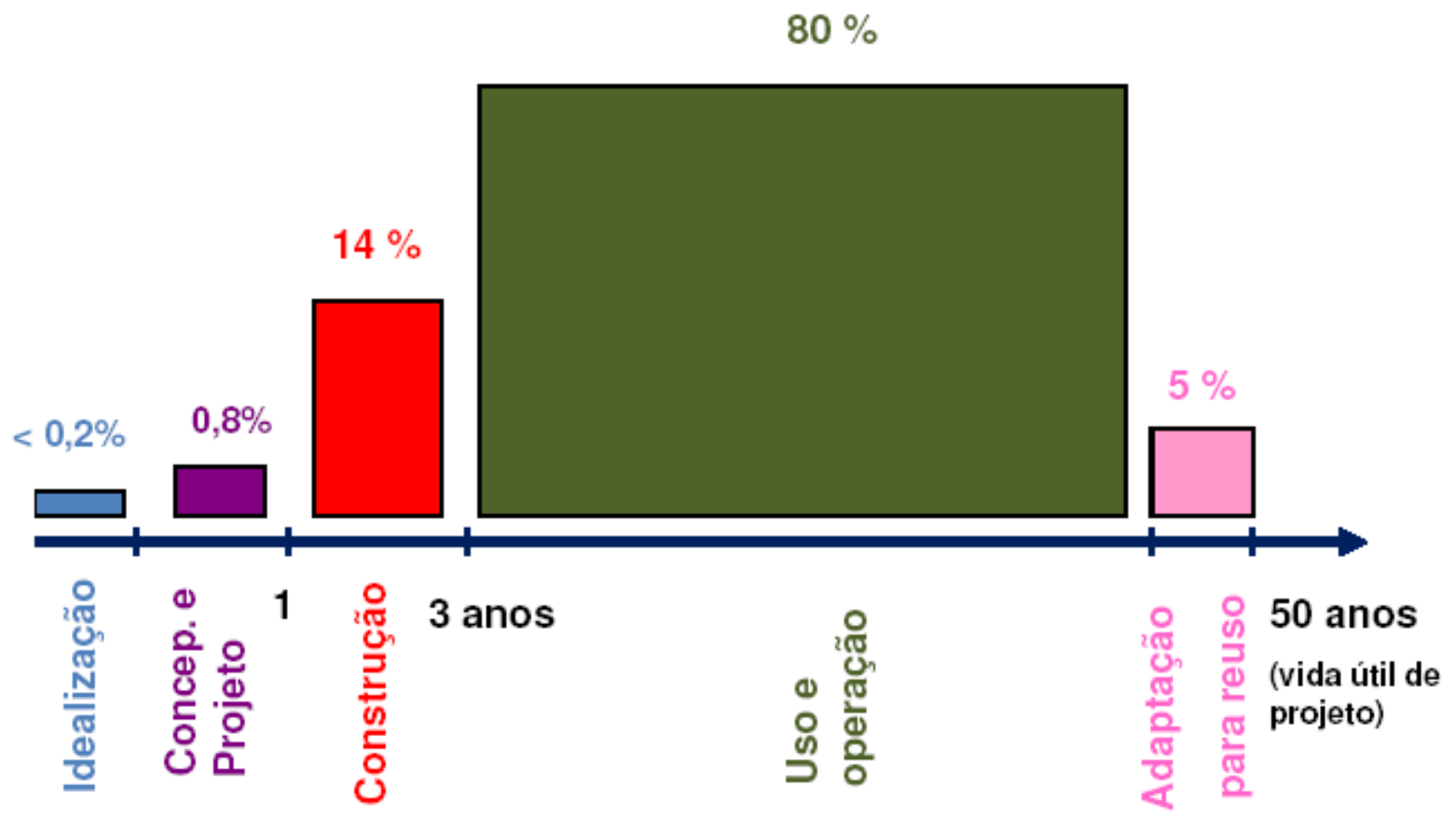

Figura 62 - Custo total de um edifício comercial em 50 anos

Fonte: Ceotto (2008)

Ainda sob este ponto de vista, há o correto entendimento de que a melhor possibilidade de se fazer qualquer interferência em um empreendimento, para que ele se torne mais ou menos sustentável, é na fase de concepção e projeto do mesmo. Parte-se do mesmo princípio para que a construção seja racional, otimizada ou econômica, ou seja, as premissas para que a edificação tenha bom desempenho (sendo seus requisitos definidos previamente) nascem de um bom projeto. 
Pela abordagem de que o grande impacto de uma edificação é durante seu uso e operação, e considerando o crescente custo dos recursos naturais não-renováveis que a edificação consome, o projeto de um edifício verde acaba por contemplar o consumo eficiente destes recursos e, quando possível, obtê-los de formas alternativas. É desta abordagem simplista, ao resolver aspectos da edificação por meio de seus sistemas prediais, que Yeang (2006) discorda. Ele aborda profundamente as questões conceituais sobre as quais o projeto ecológico está ancorado, tais como a influência do formato ${ }^{63}$ e da implantação do edifício nos seus diversos desempenhos, e dá grande importância aos sistemas passivos da edificação, que só podem ser concebidos na própria arquitetura.

Contudo, o pragmatismo por parte dos empreendedores acaba por enfatizar esta abordagem prática, que, ao focar em soluções tecnológicas para tornar o edifício mais verde que um tradicional, têm um custo adicional no investimento. Sob este ponto de vista, as soluções têm gradações quanto à sua complexidade (e consequentemente ao custo) e ao seu impacto ambiental na operação do edifício (Figura 63). Casos como o Pearl River Tower são economicamente viáveis somente devido à magnitude do projeto em si. No Brasil, o bom senso indica que as soluções que devem ser primeiramente adotadas são aquelas com baixo impacto em custo e alto impacto em desempenho do edifício.

O acréscimo no investimento, na ordem de $1 \%$ a $8 \%$ no custo de construção, segundo Ceotto (2008), tem seu retorno na economia gerada na operação do edifício, e este é um apelo de ordem prática que funciona junto aos investidores e usuários de edifícios de escritórios brasileiros. No primeiro caso, decorrente da valorização do empreendimento e, no segundo caso, com redução dos valores de manutenção (conta de condomínio). É importante salientar que alguns aspectos de uso eficiente de recursos do edifício requerem qualificação da equipe que faz a operação e manutenção do mesmo. Por este mesmo motivo, a implementação destas soluções é mais bem resolvida em edifícios de escritórios do que em edifícios residenciais.

\footnotetext{
${ }^{63}$ Ver seção 1.3 do capítulo B.
} 
Alternativas de solução e seus impactos - Edifícios Comerciais

\begin{tabular}{|c|c|c|c|c|}
\hline \multicolumn{5}{|c|}{ Impacto nos custos } \\
\hline \multirow{4}{*}{ 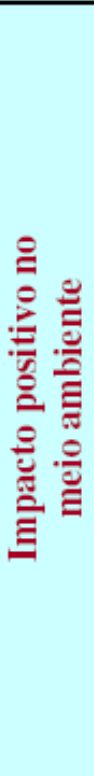 } & & Alto & Médio & Baixo \\
\hline & Alto & $\begin{array}{l}\text {-Geração local de energia com gás } \\
\text { em vez de diesel }\end{array}$ & $\begin{array}{l}\text {-Metais sunitários de baixo consumo e } \\
\text { automáticos } \\
\text {-Medição individual de ar condicionado } \\
\text {-Tratamento superficial no piso das } \\
\text { garagens. } \\
\text {-Automação de elevadores. } \\
\text {-Regeneração de frenagem nos elevadores. } \\
\text {-Roda entalpica no ar condicionado. }\end{array}$ & $\begin{array}{l}\text {-Retenção de águas de chuva } \\
\text { - Retenção de água de condensação } \\
\text { dos fancoils para uso nas torres de } \\
\text { refrigeração doa chilers } \\
\text { - Lampadas de alta eficiência. } \\
\text { - Bacias dual-flux } \\
\text {-Metais sanitários de baixa vazão e } \\
\text { automáticos. }\end{array}$ \\
\hline & Médio & -Isolaçẫo térmica de fachadas & $\begin{array}{l}\text {-Automatização da irrigação de áreas } \\
\text { verdes } \\
\text {-Vidro laminado nas fachadas } \\
\text {-Automação da iluminação das áreas } \\
\text { comuns. }\end{array}$ & $\begin{array}{l}\text {-Cobertura vegetal no térreo } \\
\text {-Isolamento térmico de coberturas } \\
\text {-Separaçấo de lixo para reciclagem }\end{array}$ \\
\hline & Baixo & $\begin{array}{l}\text {-Tratamento total de esgoto } \\
\text {-Uso de vidro insulado } \\
\text {-Reciclagem de água de lavatórios } \\
\text { para uso em bacias sanitárias }\end{array}$ & -Medição individual de água & $\begin{array}{l}\text {-Revestimentos de piso e paredes } \\
\text { facilmente laváveis. }\end{array}$ \\
\hline
\end{tabular}

Figura 63 - Gradação dos impactos de custo e ambientais das alternativas para uso eficiente de recursos em edifícios de escritórios

Fonte: Ceotto (2008) 


\subsection{ENTIDADES RELACIONADAS AO TEMA NO SETOR DA CONSTRUÇÃO}

No setor da construção, há diversas entidades atuando internacionalmente na avaliação e certificação da sustentabilidade em edifícios, cada uma com seus próprios sistemas de avaliação de desempenho. A título de ilustração, podemos citar:

- $\quad$ LEED - EUA, Canadá, Brasil

- BREEAM - Reino Unido

- CASBEE - Japão

- BEPAC - Canadá

- $\quad H K-B E A M-$ Hong Kong

- SBAT - África do Sul

As diferenças sócio-econômicas e culturais dos diversos países justificam a existência de sistemas próprios. Mesmo que todos avaliem a sustentabilidade do empreendimento em termos conceituais, o assunto, peso e ponderação de cada item a ser avaliado muda caso a caso (Figura 64). Gomes (2007) cita como exemplo o estudo feito por Crawley e Aho (1999), comparando a aplicação dos métodos BREEAM, BEPAC, LEED e GBt (Figura 65).

No Brasil, as entidades de maior destaque são: (1) o WGBC Brasil, que tem origem no modelo norte-americano e promove a difusão dos conceitos de sustentabilidade no mundo, contribuindo para a criação de conselhos de construção sustentável em diferentes países; (2) a Sustainable Building Alliance (SBA), originada no modelo francês e que está criando uma rede de entidades visando adoção de critérios para avaliação e certificação de empreendimentos. O motivo para o destaque destas entidades está nos sistemas de avaliação que elas utilizam, no primeiro caso pela influência direta de empreendedores norte-americanos em empreendimentos brasileiros e, no segundo caso, pelo trabalho de desenvolvimento de um método adequado às condições e limitações brasileiras. 


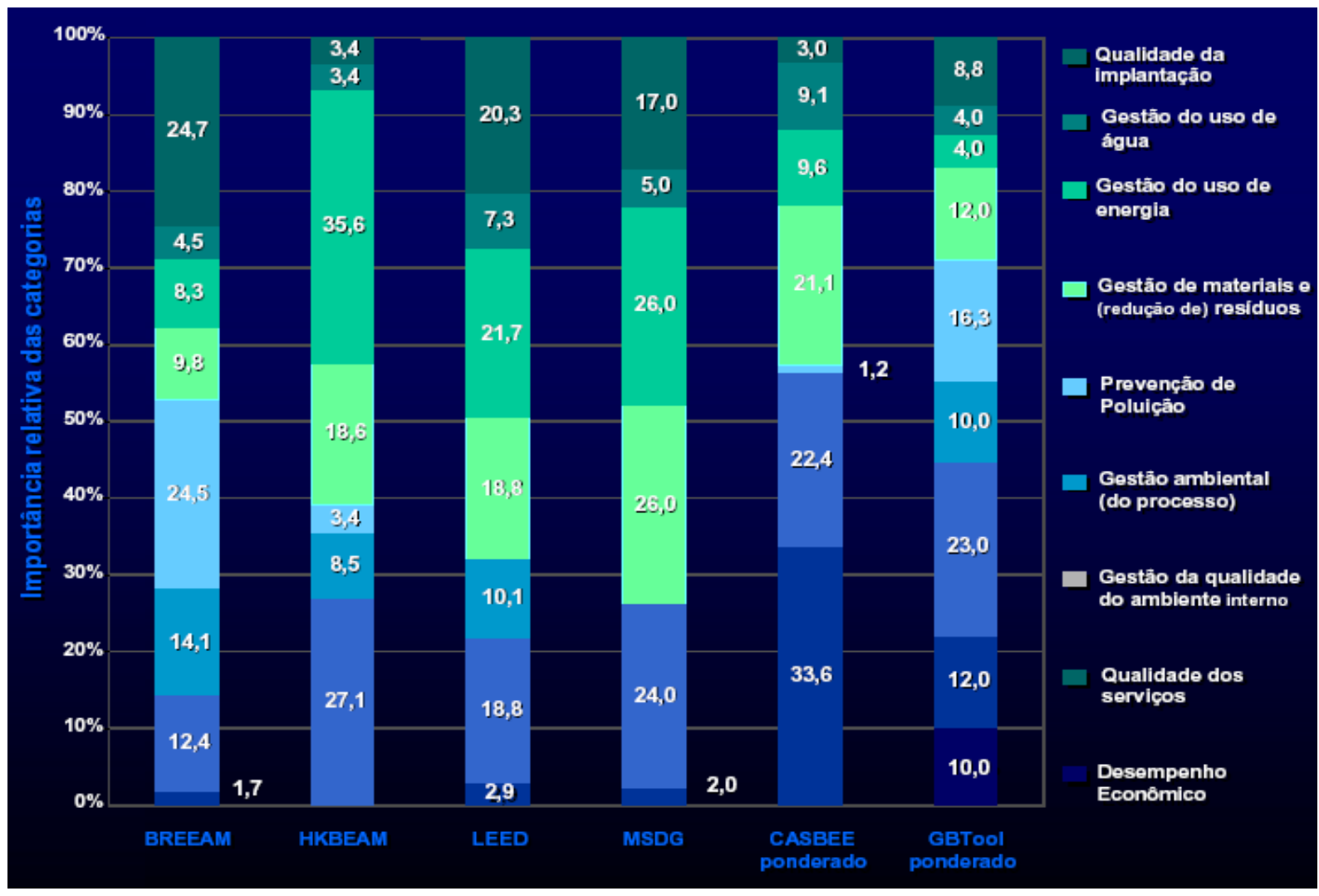

Figura 64 - Importância dos itens avaliados em diversos métodos de avaliação sobre sustentabilidade Fonte: Gomes (2007)

\begin{tabular}{|l|c|c|c|c|}
\hline Sistema & BREEAM & BEPAC & LEED & GBt \\
\hline Gestão ambiental & & $\mathbf{x}$ & & $\mathbf{x}$ \\
\hline Divulgação e Mktg & $\mathbf{x}$ & $\mathbf{x}$ & $\mathbf{x}$ & $\mathbf{x}$ \\
\hline Metas ambientais & $\mathbf{x}$ & $\mathbf{x}$ & & $\mathbf{x}$ \\
\hline Auxilio ao projeto & $\mathbf{x}$ & $\mathbf{x}$ & $\mathbf{x}$ & $\mathbf{x}$ \\
\hline $\begin{array}{l}\text { Suporte a normas } \\
\text { Espec. desempenho }\end{array}$ & & & & $\mathbf{x}$ \\
\hline Auditorias & $\mathbf{x}$ & & $\mathbf{x}$ & $\mathbf{x}$ \\
\hline
\end{tabular}

Figura 65 - Aplicação dos diversos métodos de avaliação 


\subsection{DESCRIÇÃO DOS MODELOS DE AVALIAÇÃO "LEED" E "AQUA"}

\subsubsection{LEED}

O LEED Green Building Rating System, ou simplesmente LEED, é um programa de certificação baseado em um sistema de pontuação que fornece padrões definidores de um edifício verde. Este sistema tem representantes em cerca de 14 países, é bastante adotado nos Estados Unidos e Canadá, e, por meio da difusão do WGBC e investidores imobiliários de origem norte-americana, conta com cerca de 51 empreendimentos registrados (em fase de certificação) e 10 empreendimentos certificados no Brasil (dados do Green Building Council Brasil ${ }^{64}$ em 2010).

O GBC Brasil trabalha atualmente na adaptação dos padrões do $L E E D$ para as peculiaridades do setor de construção brasileiro (LEED Brasil), incluindo questões de regulamentação, adaptação métrica e redimensionamento do sistema de pontos (por exemplo, incluindo temas como biodiversidade e impacto social positivo). No momento, os empreendimentos brasileiros utilizam o padrão norte-americano para fins de avaliação e certificação.

O LEED é um sistema bastante abrangente, de modo que o processo de certificação dos empreendimentos é separado por categorias, sendo:

- $\quad$ NC - Novas construções e grandes projetos de renovação

- $\quad E B$ - Edifícios existentes

- $\quad \mathbf{C l}$ - Projetos de interiores de edifícios comerciais

- $\quad$ CS - Projetos da envoltória e parte central do edifício

- Homes - Residências

- Schools, Healthcare, Retail - Escolas, Saúde, Varejo

- $\quad$ ND - Desenvolvimento de bairro (piloto)

Dependendo de como é feita a configuração comercial de um edifício de escritórios, a certificação pode ser feita em uma ou mais das quatro primeiras categorias acima citadas. A categoria CS (Core \& Shell), por exemplo, é utilizada por empreendedores que irão construir

${ }^{64}$ GBC Brasil (www.gbcbrasil.org.br). Acesso em 09 Fev. 2010. 
edifícios de planta livre para aluguel dos andares, cujo arranjo (lay-out) final e escolha de materiais de acabamento serão definidos posteriormente pelos locatários e usuários finais.

Os critérios para obtenção dos pontos de cada categoria estão organizados nos seguintes assuntos:
A) Espaço sustentável
B) Eficiência no uso da água
C) Energia e atmosfera
D) Materiais e recursos
E) Qualidade ambiental interna
F) Inovação e processos

Cada item de pontuação tem pré-requisitos mínimos a serem atendidos e a certificação é obtida pela somatória dos pontos obtidos, cujo valor determina se o empreendimento será nível Certificado, Prata, Ouro ou Platina. Tomando como exemplo a categoria CS (Core \& Shell), são 61 pontos possíveis, sendo 15 para o assunto (A), 5 para o (B), 14 para o (C), 11 para o (D), 11 para o (E) e 5 para o (F). A somatória de pontos para obter a certificação, neste caso, é:

Certificado: de 23 a 27 pontos;

Prata: de 28 a 33 pontos;

Ouro: de 34 a 44 pontos e

Platina: acima de 45 pontos

\subsubsection{AQUA}

O AQUA (Alta Qualidade Ambiental) é um referencial técnico para certificação em qualidade ambiental baseado no modelo francês HQE (Haute Qualité Environnementale), cujos critérios de avaliação foram adaptados para o Brasil pela Fundação Vanzolini, com o apoio de professores do Departamento de Engenharia de Construção Civil da Escola Politécnica da USP. Atualmente o referencial disponível é para edificações de escritórios e escolas e está dividido em 2 padrões:

- $\quad$ Sistema de Gestão Empresarial (SGE) 
- Qualidade Ambiental do Edifício (QAE)

O SGE apresenta quatro pontos principais, que são:

- Comprometimento

- Implantação e funcionamento

- Gestão do empreendimento

- Aprendizagem

$\mathrm{Na}$ QAE, são avaliados 14 pontos característicos da edificação, divididos em quatro categorias:

\section{Eco-construção}

1. Relação do edifício com seu entorno

2. Escolha integrada de produtos, sistemas e processos construtivos

3. Canteiro de obras com baixos impactos ambientais

\section{Eco-gestão}

4. Gestão de energia

5. Gestão de água

6. Gestão de resíduos de uso e operação do edifício

7. Manutenção - permanência do desempenho ambiental

\section{$\underline{\text { Conforto }}$}

8. Conforto higrotérmico

9. Conforto acústico

10. Conforto visual

11. Conforto olfativo

\section{Saúde}

12. Qualidade sanitária dos ambientes

13. Qualidade sanitária do ar

14. Qualidade sanitária da água

As duas primeiras categorias referem-se ao gerenciamento dos impactos sobre o ambiente exterior, e as duas últimas referem-se à criação de condições para um espaço interior (da edificação) sadio e confortável. 
A forma de avaliação dos pontos baseia-se no critério de desempenho em três níveis: bom (prática corrente), superior (boas práticas) e excelente (melhores práticas). O perfil mínimo para obtenção de certificado deve apresentar pelo menos três pontos em nível excelente e no máximo sete pontos no nível bom, sendo o restante no nível superior (Figura 66).

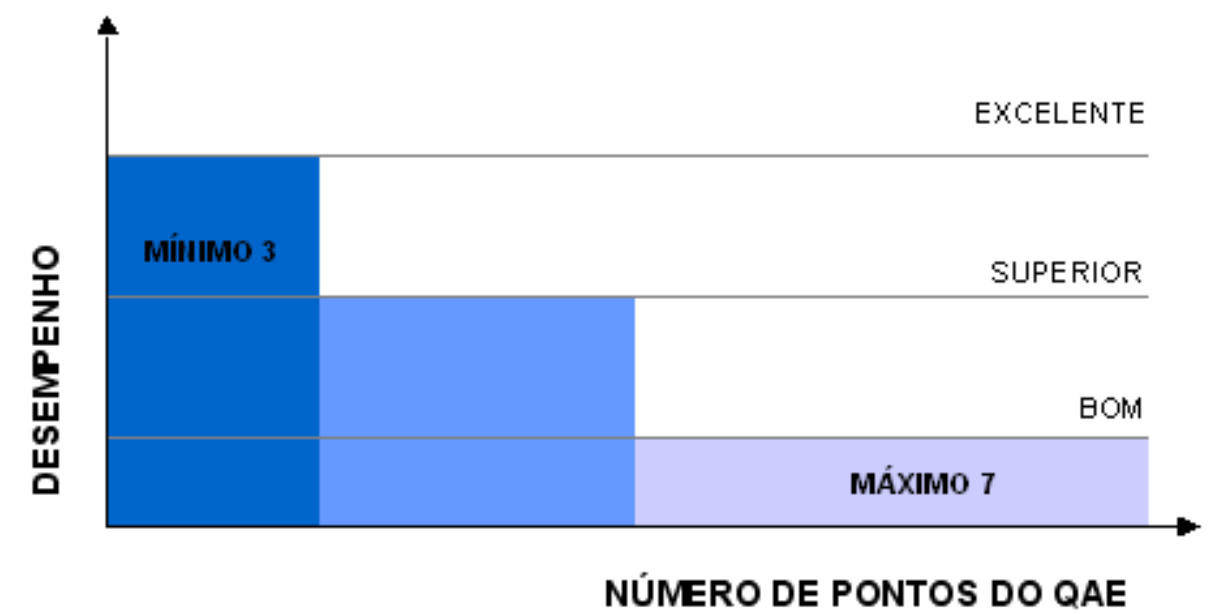

Figura 66 - Perfil mínimo de desempenho para certificação pelo processo AQUA Fonte: Ferreira (2008)

A satisfação das exigências dos pontos pode se manifestar de dois modos: (1) quando o critério é avaliável, pela comparação de seu valor com um valor de referência; e (2) quando o critério não é avaliável, pela verificação de que exigências são formuladas para as fases posteriores do processo de construção, em função do desempenho visado.

A certificação é feita em três fases: programa (quando o empreendedor está concebendo o empreendimento como negócio), concepção (fase do projeto) e realização (fase obra), permitindo a verificação em diferentes etapas do empreendimento de qual perfil ambiental visado será atingido.

Segundo a Fundação Vanzolini ${ }^{65}$ (2009), atualmente há quatro empreendimentos em processo de desenvolvimento de programa, sendo um conjunto residencial, um centro educacional e um centro de convenções em São Paulo, e um complexo hoteleiro em Pernambuco.

\footnotetext{
$65<$ www.vanzolini.org.br>. Acesso em 09 Fev. 2010.
} 


\subsubsection{Análise comparativa dos sistemas de avaliação}

De modo geral, tanto o LEED quanto o AQUA avaliam a condição de implantação das edificações, a eficiência do consumo de água e energia e a qualidade ambiental interna do edifício e aspectos ligados ao processo de construção, seja pelo controle do resíduo das obras, seja pela escolha e utilização dos materiais de construção. As diferenças principais ocorrem na forma como estes itens são avaliados e no resultado final desta avaliação. $O$ LEED utiliza um sistema de somatória de pontos dentro um universo de parâmetros já categorizados; o AQUA utiliza um critério comparativo para classificar a avaliação de seus itens.

O sistema de avaliação por pontuação do LEED tem um caráter mais pragmático, aparentemente mais objetivo. O ponto somente é considerado com o atendimento pleno do item. Por outro lado, não há ponderação direta nestes pontos, ela ocorre já na parametrização dos itens (cada categoria tem um valor de somatória diferente para obtenção de nível de certificação) e na colocação de pré-requisitos nos assuntos. Neste raciocínio, é possível obter pontuação suficiente para certificação deixando de atender completamente um dos seis possíveis assuntos. Por exemplo, na categoria CS, um empreendimento hipotético conseguiria um nível máximo de certificação (Platinum, a partir de 45 pontos em 69 possíveis) sem atender a um só requisito de uso eficiente de água (que soma cinco pontos).

O sistema de avaliação do AQUA aparenta ter mais ponderação e flexibilidade, por utilizar um método comparativo. Em função disso, é um método que, em teoria, possibilita evolução pelo próprio funcionamento, pois os parâmetros para comparação podem ficar mais rigorosos com o passar do tempo: se, hipoteticamente, todos os projetos passarem a adotar as melhores práticas (nível excelente), estas passam a ser práticas correntes (nível bom), e então as melhores práticas passam a ser outras, em um movimento de melhoria contínua. 


\subsection{CONSIDERAÇÕES SOBRE O ASSUNTO}

O tema sustentabilidade na construção não parece dar sinais de que será um modismo passageiro. É possível imaginar, pela crescente preocupação e engajamento de populações, entidades e governos, que, em um futuro próximo, os itens de avaliação de desempenho das edificações, que hoje são considerados como agregadores de valor, passem a fazer parte de normas ou códigos, ou seja, passem a ser obrigatórios. Há ainda um longo caminho a percorrer, pelo menos no Brasil, para se chegar a este ponto, mas indícios já aparecem. Fernandes e Salvador (2008), do jornal O Estado de São Paulo, informam que o governo federal prepara decreto para regulamentar as compras da administração pública segundo regras de sustentabilidade, principalmente para produtos como papel, mobiliário e lâmpadas.

A eficiência de um edifício verde (que muitos gostam de chamar de sustentabilidade de uma edificação) é determinada no projeto, principalmente na fase de concepção e estudos iniciais. Como ela envolve todos os aspectos multidisciplinares de uma edificação, o papel do arquiteto torna-se ainda mais fundamental na hora de conceber o partido arquitetônico e traduzir o programa de necessidades do empreendedor, alinhando-o a princípios sustentáveis. Deve-se entender o movimento de sustentabilidade como uma oportunidade para valorização deste profissional, principalmente no Brasil, para sua correta atuação dentro da cadeia de agentes envolvidos em um empreendimento. Também se deve considerar a adoção de conceitos de sustentabilidade na formação acadêmica, não só dos arquitetos, mas também dos engenheiros e demais profissões que atuam no mercado da construção.

Quanto aos aspectos de avaliação de desempenho das edificações, é importante comentar que tanto o WGBC quanto o SBA são entidades que fomentam os estudos, as diretrizes e os modelos a respeito das edificações verdes ou ecológicas, mas não fazem a avaliação para fins de certificação. Esta avaliação é feita por empresas terceiras, devidamente qualificadas e acreditadas para tal. Não se pode perder de vista de que a certificação é um negócio comercial, e isto, em parte, explica o porquê da existência de tantos modelos de avaliação nos diversos países e de mais de um modelo no Brasil.

O aspecto positivo da certificação como negócio é seu apelo comercial e pragmático junto aos investidores imobiliários, que entendem que desta forma valorizarão seus empreendimentos, justificando os investimentos adicionais e fazendo que as novas edificações sejam concebidas, projetadas e construídas de modo mais eficiente e mais 
sustentável. Outro aspecto positivo é incluir no processo da certificação a preocupação com a seleção dos materiais construtivos, fazendo que os aspectos relacionados ao consumo de energia para fabricar tais materiais sejam, indiretamente, contemplados.

O aspecto negativo é o perigo de se criar uma "indústria" de certificações, na qual ao investidor só interessa obter a certificação em si, sem se preocupar realmente com as questões de sustentabilidade de seu empreendimento e de seu negócio. Este tipo de atitude, em médio prazo, pode acabar por desqualificar a importância da avaliação e da própria certificação. 


\section{CAPÍTULO D - ESTUDO DE CASO}

\section{APRESENTAÇÃO}

O objeto de estudo é um caso único e trata do processo de projeto de uma empresa privada de incorporação, multinacional (Figura 67), com sede original nos EUA, presente no Brasil desde 1996, verticalmente integrada e com atuação em toda a cadeia do desenvolvimento imobiliário (desde a concepção do negócio até a administração predial). Para ilustrar o resultado técnico deste processo, são também apresentados alguns empreendimentos de edifícios de escritórios desenvolvidos por esta empresa.

A coleta de dados deu-se por entrevistas com os responsáveis pela diretoria técnica (Projeto \& Construção), pessoas-chave do Departamento de Projetos, arquitetos, coordenadores e projetistas envolvidos em alguns processos de projeto; comparecimento a reuniões de coordenação de projetos e consulta a documentos gerados ao longo do processo, tais como: plantas, memoriais e atas de reunião, além de documentos de gestão do próprio departamento.

Por motivos de confidencialidade solicitados pela incorporadora, as fontes dos projetos e documentos que aparecem neste trabalho não são identificadas e são apenas referenciadas como "incorporadora" ou "incorporadora em estudo".

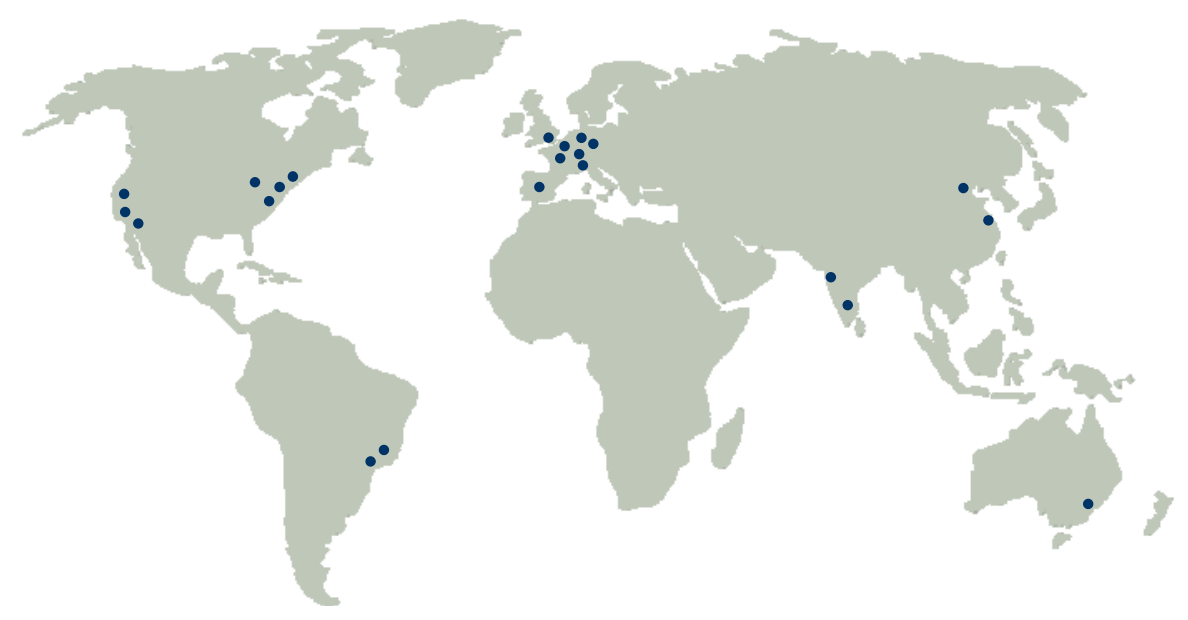

Figura 67 - Área de atuação da incorporadora pelo mundo 
No Brasil, a incorporadora desenvolve projetos no mercado imobiliário nas cidades de São Paulo, Rio de Janeiro e Brasília, nos segmentos de construções comerciais e residenciais de alto padrão. Sua atuação se dá por meio de administração de fundos imobiliários e sua posição no mercado é caracterizada pelo seu patrimônio, ao invés de seu faturamento anual. Os dados levantados do ano de 2007 indicam um valor de patrimônio acumulado de aproximadamente U\$ 30 bilhões ao redor do mundo e de fundos administrados no Brasil por volta de U\$ 18 bilhões.

Para dar suporte às atividades de toda a cadeia do desenvolvimento imobiliário, a subsidiária brasileira da incorporadora apresenta uma estrutura organizacional (simplificada pela autora) ilustrada pela Figura 68.

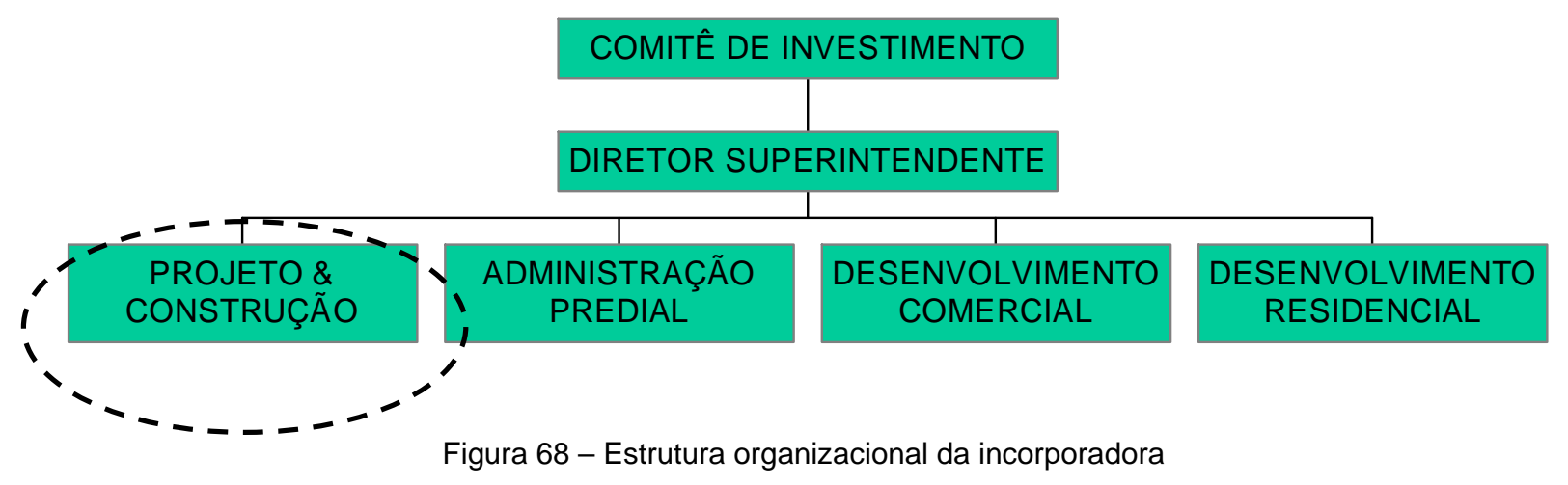

A área da incorporadora que se relaciona diretamente com a produção de edifícios é o Departamento de Projeto \& Construção (Figura 69) e, embora a empresa não execute propriamente a construção dos edifícios que incorpora, tem a necessidade de dominar minimamente os requisitos de custos, qualidade e prazos desta atividade, para ter condições de exigi-los das construtoras que contrata. O mesmo acontece com o desenvolvimento e a coordenação de projetos.

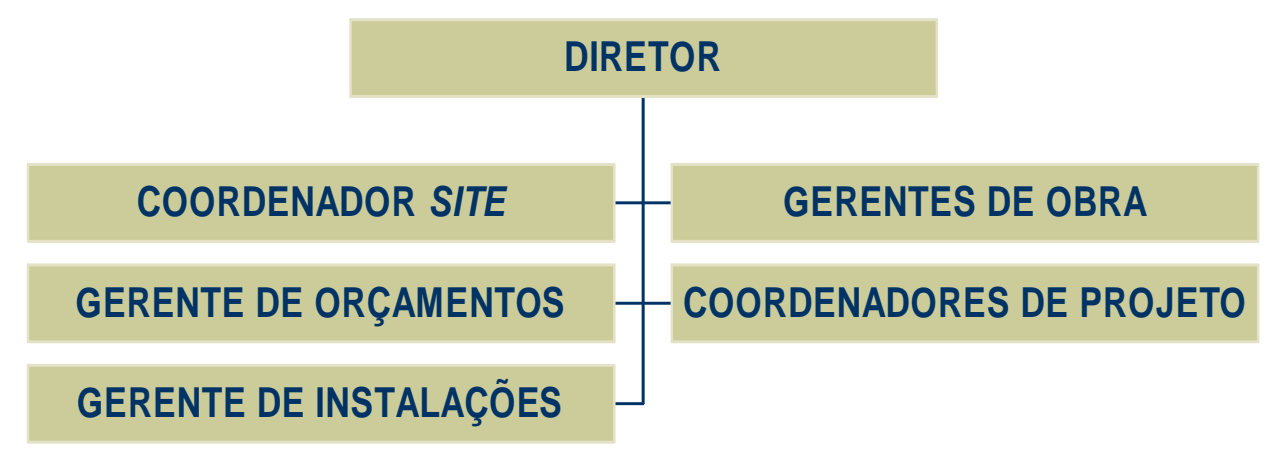

Figura 69 - Estrutura organizacional do departamento de Projeto \& Construção da incorporadora 


\section{PROCESSO DE PRODUÇÃO}

Com o objetivo de garantir que os requisitos dos produtos imobiliários sejam alcançados, mesmo sem fazer a execução própria de seus projetos e construções, a incorporadora apresenta fluxos estruturados de ações que se iniciam desde a fase de concepção do negócio até a manutenção do edifício. Seu processo de produção como um todo pode ser resumido em quatro principais fases, a saber: concepção do produto, desenvolvimento do projeto, construção e manutenção (Figura 70).

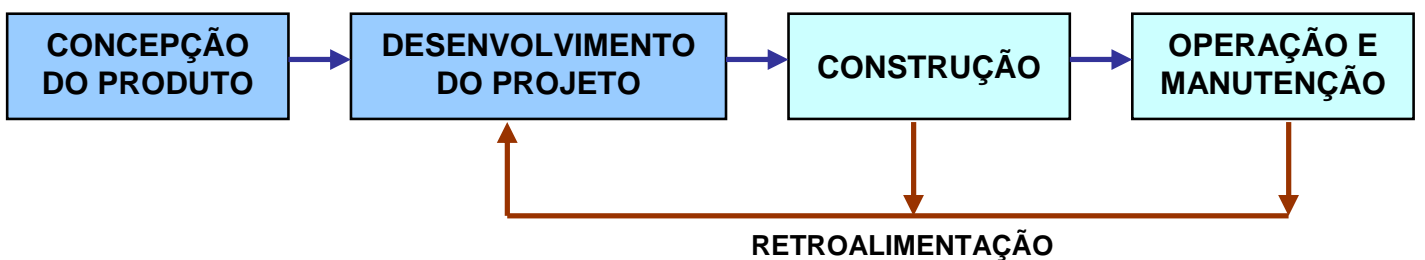

Figura 70 - Fases do processo de produção da incorporadora

Este processo, cujas fases são detalhadas abaixo, é utilizado nas incorporações de empreendimentos, tanto do segmento comercial (caracterizados pelos edifícios de escritórios), quanto do residencial. 


\subsection{CONCEPÇÃO DO PRODUTO}

O Departamento de Projeto \& Construção (P\&C) tem como uma das funções assessorar a área de Desenvolvimento Comercial (DC) na definição do produto imobiliário, utilizando as diretrizes por ele desenvolvidas, nas quais se estabelecem as características do produto em análise, relacionadas com a faixa de valores estimados de custo e de venda. O fluxo desta etapa do processo (Figura 71) inicia-se com a área de DC, que prospecta um terreno ou negócio já formatado e o apresenta às demais diretorias, que decidem se vão seguir em frente com as análises.

Após este primeiro filtro, que é intuitivo e baseado no conhecimento do mercado, define-se pela continuação ou não das negociações, o que implica apresentar ao Comitê de Investimento $(\mathrm{Cl})$ um memorando com as intenções do negócio, de uma maneira geral. Neste memorando, devem constar os resultados de uma "due diligence", que é a averiguação das características jurídicas do terreno ou negócio, e um valor estimado de construção para o empreendimento, este último elaborado pelo Departamento de P\&C.

Após aprovação do memorando pelo $\mathrm{Cl}$, um "Programa Básico de Massas" é solicitado a um arquiteto e, por meio de uma reunião de trabalho, são definidas as primeiras diretrizes do produto imobiliário, que tratam de características essencialmente comerciais do empreendimento, tais como: restrições legais, padrão de acabamento, áreas de laje, áreas privativas, forma e área de núcleo do pavimento, número de subsolos, número de vagas de veículos, espaçamentos e número de andares. Com base no trabalho do arquiteto e por meio de uma metodologia própria, o Departamento de $\mathrm{P} \& \mathrm{C}$ fornece uma primeira referência de custos do empreendimento e um cronograma de desembolso, que balizam o estudo de viabilidade econômica do negócio.

Se o custo apresentado não estiver dentro das expectativas assumidas no momento da compra do terreno, volta-se para a área de DC e eventuais sócios, para que ajustes no produto sejam feitos (quantidade de vagas, tamanho da unidade privativa, programa do apartamento e do empreendimento, etc) e estudos de engenharia de valor sejam desenvolvidos. Estes estudos consideram valores estimados para caracterizar os impactos das decisões comerciais e técnicas de projetos no produto. No intuito de se alcançar o objetivo inicial firmado com o $\mathrm{Cl}$, estes ajustes de produto, em algumas vezes, podem mudar completamente as características iniciais. Quando o custo atinge os parâmetros aceitáveis, passa-se para o desenvolvimento do Projeto Preliminar. 


$\begin{array}{cc}\text { ATIVIDADES } & \text { ATIVIDADES } \\ \text { COORDENADAS } & \text { COORDENADAS } \\ \text { POR DC } & \text { POR P\&C }\end{array}$

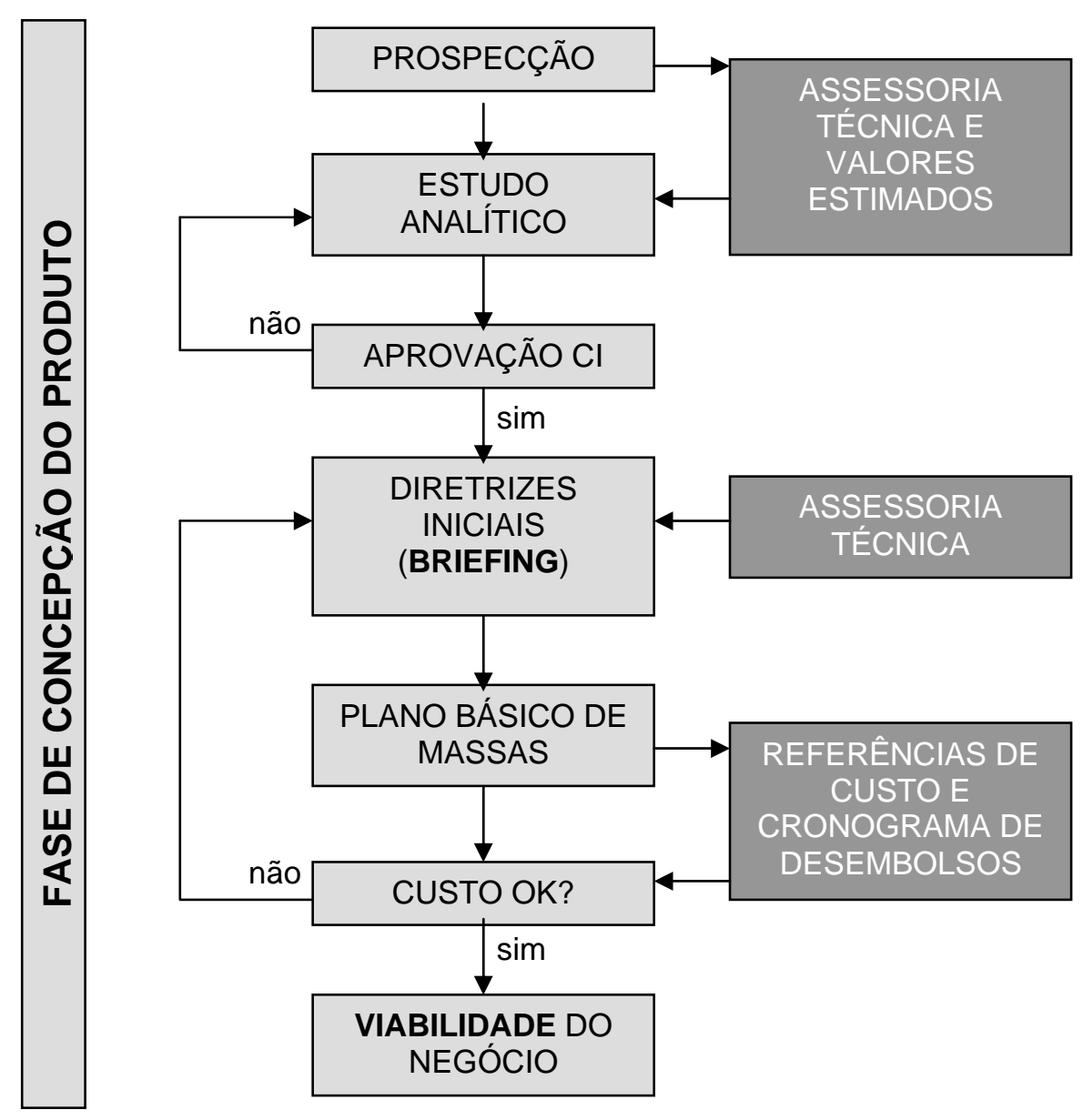

Figura 71 - Fluxo do processo da incorporadora da fase de concepção do produto 


\subsection{DESENVOLVIMENTO DO PROJETO}

Como a conclusão da viabilidade do negócio, inicia-se a fase de Desenvolvimento de Projetos, coordenada pelo Departamento de P\&C. Esta fase é dividida nas seguintes etapas: Projeto Preliminar, Anteprojeto, Projeto Básico e Projeto Executivo (Figura 72).
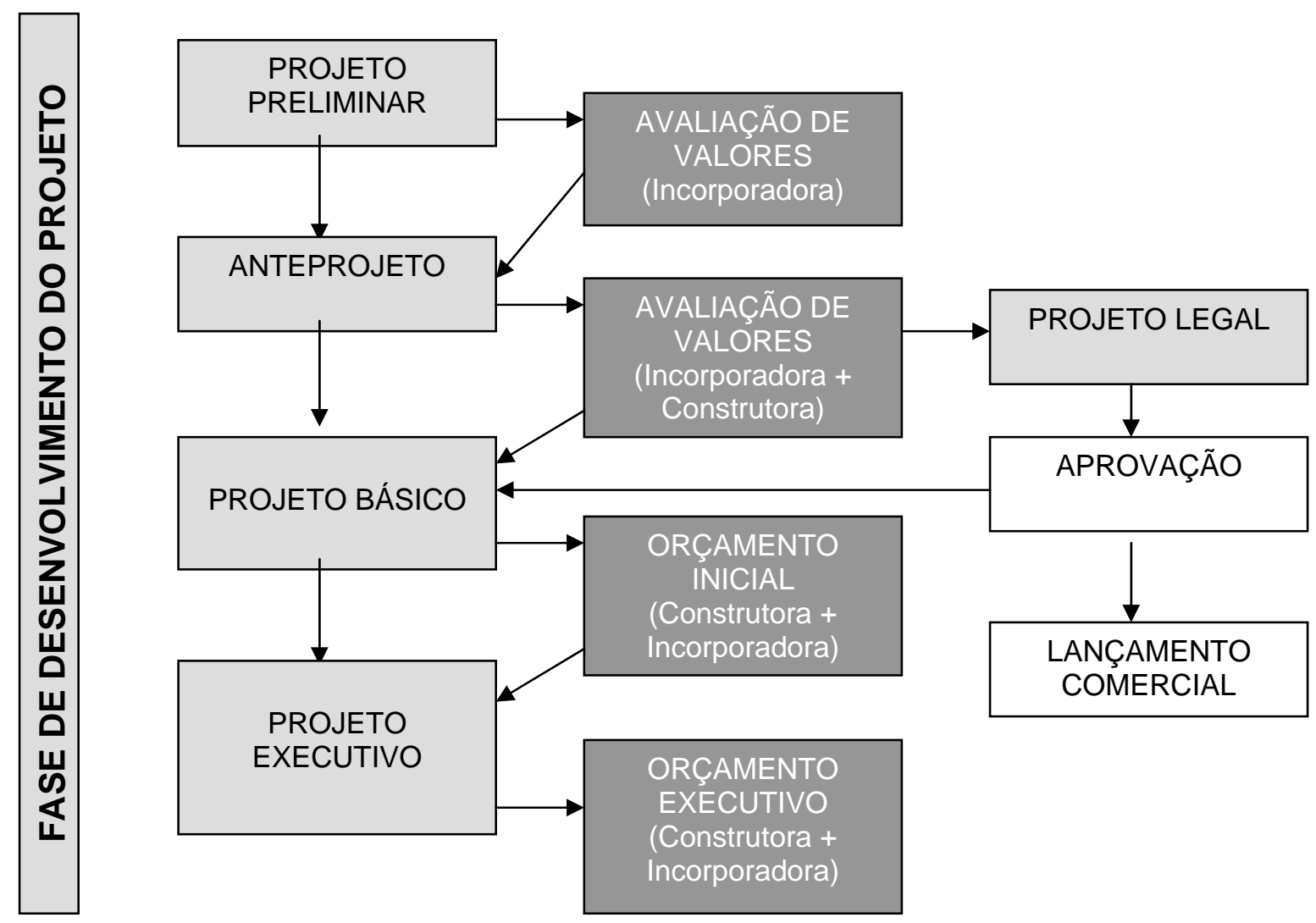

Figura 72 - Fluxo do processo da incorporadora da fase de desenvolvimento do projeto

\subsubsection{Projeto Preliminar}

Nesta etapa, ocorre o desenvolvimento, pelo arquiteto autor do projeto, dos primeiros esboços amadurecidos das diretrizes de projeto, com a definição da geometria, o dimensionamento macro de áreas e a formatação de seu primeiro memorial. A confirmação das exigências legais iniciais, levantadas no estudo analítico, junto com o levantamento de 
todo o restante dos parâmetros da legislação, é também característica desta fase, e geralmente é delegada a consultores específicos. Outro ponto importante que começa a ser definido nesta fase é o partido arquitetônico da fachada, ou seja, a imagem que se deseja projetar do produto imobiliário.

O Projeto Preliminar é, então, novamente submetido a uma avaliação de custos para verificar adequação ao objetivo inicial firmado com o Cl. Esta constante submissão para avaliação de custos é uma medida cautelosa e tem os objetivos de nortear a evolução do projeto e permitir, ainda na sua concepção, mudanças conceituais no mesmo, de modo a atender às expectativas comerciais, técnicas e de retorno do negócio.

\subsubsection{Anteprojeto}

Após a verificação da adequação do Projeto Preliminar aos custos esperados, inicia-se a etapa do Anteprojeto, que é marcada pelas definições das demais disciplinas de projeto e consultorias, respectivas empresas que vão desenvolvê-las, escopo de trabalho e planejamento inicial, com principais datas de cronograma. Também a figura do coordenador de projetos é definida, normalmente um agente externo à incorporadora, para evitar sobrecargas de sua equipe interna. Disciplinas complementares muito comuns em projetos de edifícios de escritório contratadas pela incorporadora são: estrutura, fundações, instalações prediais, sistemas mecânicos, elevadores, sistemas de segurança pessoal e patrimonial, estacionamento de veículos, consultoria de fachada, consultoria de esquadrias, impermeabilização, acessibilidade e sustentabilidade do edifício (esta última com fins específicos de certificação).

Ao final desta etapa, são desenvolvidos desenhos iniciais baseados nas informações até então disponíveis, com os propósitos de efetuar estudos de eventuais interferências físicas entre disciplinas e de preparar a base para o projeto de aprovação legal. O projeto é submetido novamente à avaliação de custos por parte do $P \& C$ e também por parte de uma construtora, se esta já estiver comercialmente envolvida. A aprovação do projeto legal permite que seja feito o lançamento do empreendimento para o mercado. 


\subsubsection{Projeto Básico}

Nesta etapa, ocorre o desenvolvimento do projeto nas diversas disciplinas e as reuniões de coordenação. O início do detalhamento dos conceitos aprovados de todas as disciplinas possibilita a visualização de diversas interferências entre projetos, como, por exemplo, a dificuldade de harmonizar os conceitos da segurança patrimonial com a segurança pessoal (a primeira dificulta os acessos, a segunda necessita liberá-los); o remanejo de ambientes próximos a estacionamentos para melhorar a fluidez de veículos; a necessidade de se definir como os projetos de ar condicionado, arquitetura e sistemas prediais podem atender a requisitos para obtenção de pontos para certificação de "green building"; a inclusão de espaços para recepção específica de entregadores; e como prever em projeto elementos que favoreçam a gestão do uso de água de fontes alternativas (águas pluviais e reuso de esgoto). Este detalhamento também permite que questões relacionadas aos sistemas prediais e às garantias de funcionamento do edifício, mesmo em situações especiais, sejam definidas, tais como: mecanismos para proteger ou mitigar ações decorrentes de enchentes; mecanismos para evitar que eventuais panes nos sistemas hidráulicos dos andares comprometam o funcionamento dos elevadores, devido ao acúmulo da água no poço do elevador; e mecanismos para o funcionamento mínimo dos sistemas elétricos em caso de pane no fornecimento.

A validação das soluções técnicas dos projetos complementares, com sua incorporação no projeto de arquitetura e consequente compatibilização entre os mesmos, constituem os produtos desenvolvidos nesta etapa, que dão origem ao Orçamento Inicial, utilizado como balizador para a primeira fase da futura construção do empreendimento (preparo do terreno, escavação, contenção e fundação). Este orçamento é desenvolvido pela construtora (que já deve estar envolvida) e tem que ser validado pela incorporadora.

\subsubsection{Projeto Executivo}

O detalhamento natural dos projetos da etapa anterior constitui o Projeto Executivo, cujos documentos gerados devem possibilitar a elaboração do Orçamento Executivo. Durante este detalhamento, ainda há possibilidade de alterações e ajustes no projeto, e as análises de custo e engenharia de valor são efetuadas simultaneamente, apoiando as tomadas de decisão. 
O Orçamento Executivo apresentado pela construtora serve de base para acompanhamento de seu desempenho para fins de premiação na modalidade contratual PMG ${ }^{66}$. Também serve para acompanhar o desempenho do negócio como um todo na fase de construção.

A transição desta etapa para a de construção é realizada pelo desenvolvimento dos projetos de fabricação (ou projetos para produção) e de amostras específicas em tamanho real, denominadas mock-ups, nas quais são identificados os padrões de acabamento aceitáveis e o funcionamento de alguns tipos de sistemas.

66 Preço Máximo Garantido. Modalidade de contratação de construção na qual é estabelecido um teto para o valor de construção e cujos valores das composições dos custos são de conhecimento da contratante, sendo que as economias obtidas durante a gestão da obra são objeto de premiação previamente negociada. 


\subsection{CONSTRUÇÃO}

A incorporadora faz o gerenciamento das atividades de orçamento e construção, realizadas por construtoras, por meio de exigências sobre cumprimento de prazo, custo e plano de qualidade das obras, de modo a garantir o desempenho do negócio. A área responsável por este gerenciamento é o P\&C.

A fase de construção (Figura 73) tem interações com e durante a fase anterior, de Desenvolvimento de Projeto, pois se inicia com a elaboração do Orçamento Inicial, elaborado no final da etapa do Projeto Básico. O Orçamento Inicial dá origem ao Planejamento Inicial, e ambos são submetidos à aprovação pela incorporadora.

A aprovação destes permite que a fase inicial de obras, caracterizada pelas atividades de preparação do terreno e de execução de infra-estrutura (montagem de canteiro, escavação, contenção e fundação) seja realizada. O acerto comercial que a incorporadora tem com a construtora, nesta fase inicial, é regido pela modalidade de contrato por administração. Isto é devido a experiências adquiridas, pela incorporadora, em construções de vários outros empreendimentos, que indicam um certo grau de risco no comportamento do solo durante estas obras de preparação.

O Orçamento Executivo é elaborado com os documentos gerados na etapa do Projeto Executivo e é utilizado como balizador para fazer o fechamento das grandes contratações de execução do projeto. Quando o valor destas contratações atinge $70 \%$ do valor total, é fechado um Orçamento de PMG, e, baseado nele, é feita uma mudança da relação contratual da construtora com a incorporadora, que passa a ser na modalidade PMG. Isto significa que o Orçamento PMG é utilizado pela incorporadora como referência de desempenho da construtora, tanto para o acompanhamento de custos, quanto para fins de bonificação.

Os dados de orçamentos, tanto do Executivo quanto do PMG, aliados ao resultado final da obra, retroalimentam a área de custos da incorporadora com informações atualizadas, que podem ser utilizadas em outros estudos e orçamentos estimativos.

O P\&C acompanha a construção, aprova as medições de serviços e solicita eventuais ajustes no planejamento. O recebimento das obras, por parte da incorporadora, fica condicionado ao comissionamento (start-up) de equipamentos e dos sistemas prediais. Neste momento, o recebimento é feito pelo Departamento de Administração Predial (AP), que será a responsável pela operação e manutenção do edifício. 


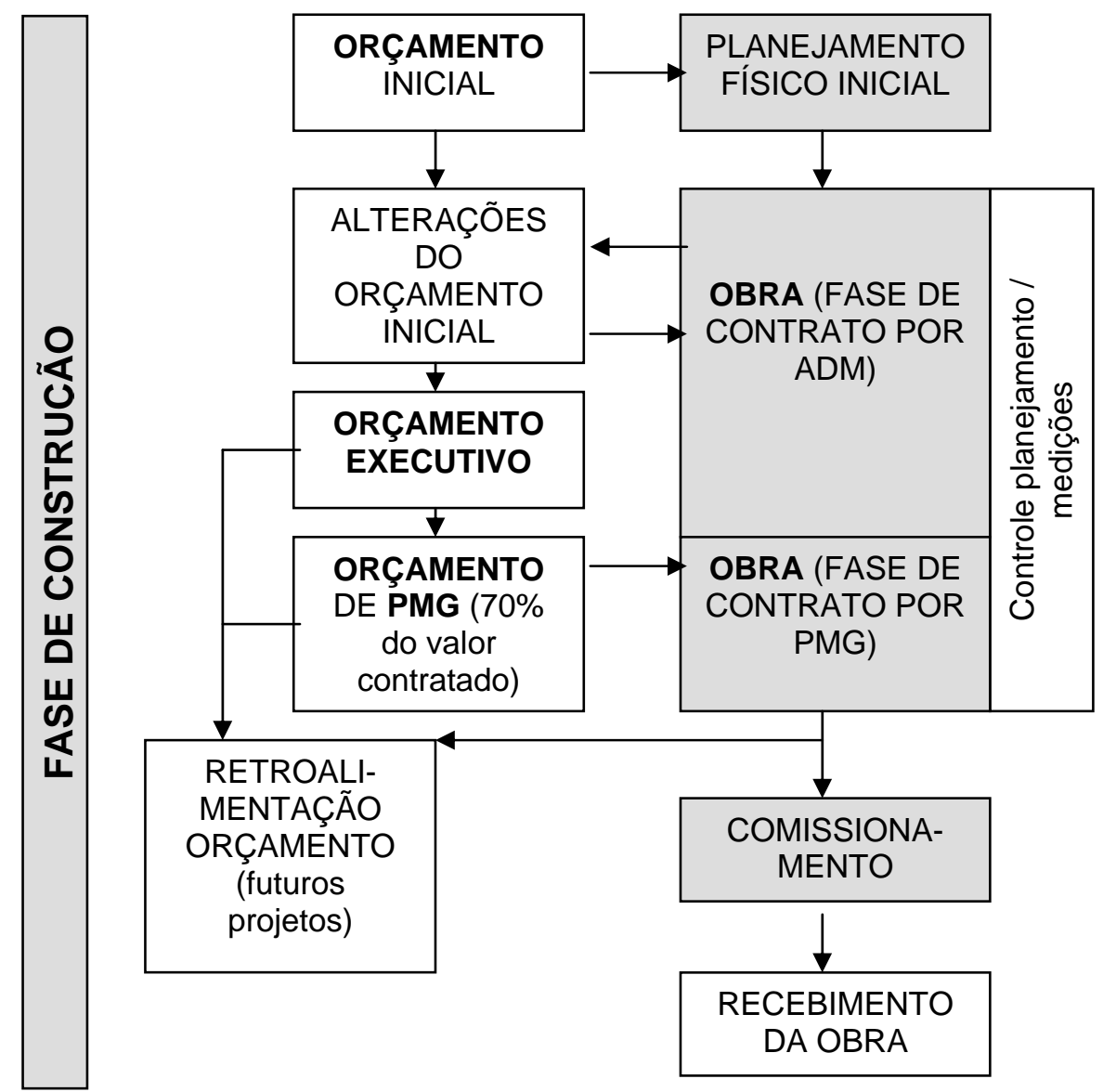

Figura 73 - Fluxo do processo da incorporadora da fase de construção 


\subsection{OPERAÇÃO E MANUTENÇÃO}

A construtora é responsável pela manutenção e pela validade das garantias legais da edificação durante aproximadamente cinco anos, prazo estipulado pelo Código do Consumidor. A incorporadora, por ser responsável pela operação do edifício e por ter origem norte-americana, tem ciência sobre os critérios de vida útil e de desempenho de edificações $^{67}$ daquele país e, aplica, quando possível, os conceitos destes requisitos nos empreendimentos brasileiros.

Após cerca de dois a três anos de ocupação, o Departamento de AD da incorporadora contrata uma empresa especializada para realizar uma avaliação pós-ocupação com a área de Gerenciamento de Facilidades das empresas locatárias. Os resultados destas avaliações, junto com os relatórios de assistência técnica feitos pelo $A D$, fornecem dados de retroalimentação do sistema para definição de novos projetos, que podem resultar em alteração de diretrizes técnicas ou melhorias de seu processo de produção.

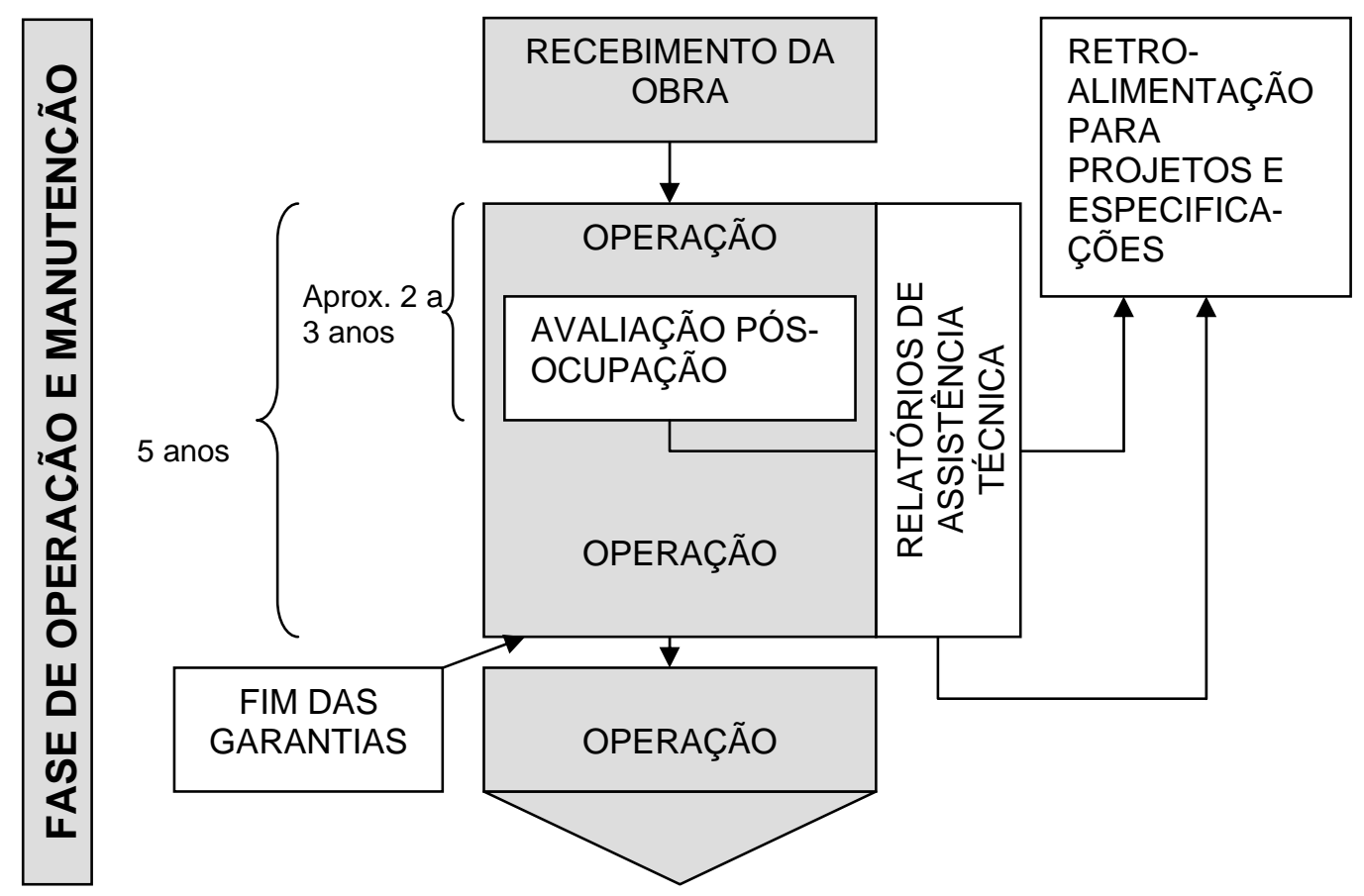

Figura 74 - Fluxo do processo da incorporadora da fase de manutenção

67 A normatização brasileira sobre desempenho em edificações é recente e aplicável somente a edificações residenciais de até cinco pavimentos. 
É importante frisar que o Departamento de $A D$ faz a operação e manutenção das áreas comuns dos empreendimentos, ou o "Gerenciamento de Propriedade ${ }^{68 " . ~ T o d o s ~ o s ~ s e r v i c ̧ o s ~}$ previstos no Gerenciamento de Facilidades, que estão na área comum, são de responsabilidade da incorporadora. As avaliações de pós-ocupação referentes às áreas privativas são feitas por meio de pesquisa de satisfação junto aos responsáveis pela área de Facilities das empresas locatárias.

A principal ação de retroalimentação que o Departamento de AD faz no processo de projeto ocorre nas reuniões de validação. Ele opina principalmente nas questões sobre os tipos de materiais de acabamento, nos espaços para acessos a equipamentos, na facilidade para limpeza das instalações e nas dificuldades de operação que alguns sistemas podem ocasionar. O Departamento de AD não interfere pro-ativamente nas definições conceituais dos sistemas prediais, apenas emite sua opinião sobre a conveniência comercial (ex: desempenho do atendimento de empresas fornecedoras de equipamentos) e de manutenção sobre estes sistemas, o mesmo ocorrendo com os materiais de acabamento.

Um aspecto interessante sobre a operação e manutenção dos empreendimentos da incorporadora refere-se ao sistema de transporte vertical, cujo padrão de contrato de manutenção difere do que normalmente é oferecido no mercado local. A abrangência internacional de seus empreendimentos permite que a incorporadora adote alguns itens de desempenho sugeridos por Van Deusen ${ }^{69}$ (2002) nos contratos de manutenção brasileiros, o que certamente traz um diferencial no padrão mercadológico de seus empreendimentos.

\footnotetext{
${ }^{68}$ Ver seção 2.1 do capítulo $C$.

${ }^{69}$ Ver seção 3.7.9 do capítulo B.
} 


\section{FERRAMENTAS PARA O PLANEJAMENTO DO PROCESSO DE PROJETO}

A incorporadora em estudo dispõe de uma estrutura relativamente pequena para gerenciar o processo de projeto (a variação de quadro interno deste departamento ao longo do desenvolvimento deste trabalho foi entre duas e três arquitetas, que coordenam, cada uma, cerca de quatro empreendimentos), uma vez que o desenvolvimento dos projetos é feito por meio de projetistas e consultores contratados externamente. Por este motivo, ela é obrigada a dispor de ferramentas de supervisão e controle para a gestão deste processo. A principal delas refere-se ao Manual de Coordenação de Projetos, que contém as principais diretrizes que devem ser seguidas pelo coordenador de projetos e os modelos de formulários que devem ser utilizados ao longo do processo (Figura 75).

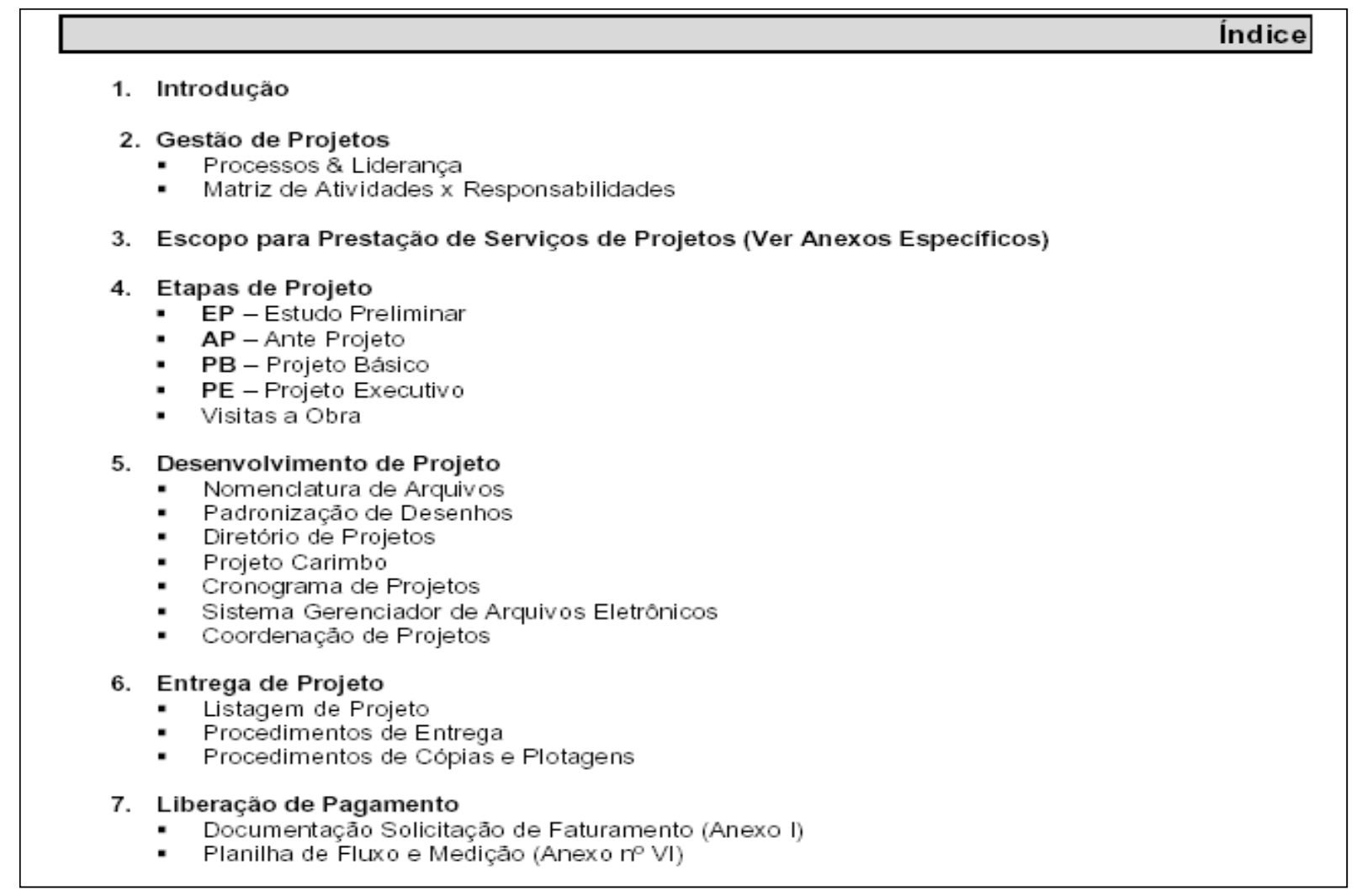

Figura 75 - Conteúdo do Manual de Coordenação de Projetos da incorporadora

Dois itens podem ser destacados do conteúdo deste manual: a Matriz de Atividades $\mathrm{x}$ Responsabilidades e o Escopo para Prestação de Serviços de Projetos. Estes itens dizem 
respeito à forma como a incorporadora lidou com a questão do escopo na gestão do processo de projeto. O escopo é detalhado por disciplina de projeto e é apresentado ao projetista em um momento anterior à contratação. Este modelo é específico da incorporadora, por ela ser obrigada, em alguns casos, a seguir normas internacionais, principalmente as relacionadas à segurança pessoal. A matriz de atividades, por sua vez, estabelece as responsabilidades de cada agente envolvido e orienta a equipe sobre a quem cabem as decisões a serem tomadas ao longo do processo.

O planejamento dos prazos, ainda segundo o modelo deste Manual, é feito por meio de cronograma de barras.

Os modelos de formatação de desenhos, tamanhos de folha, carimbos e nomenclaturas para camadas de desenho (layers) pressupõem que todos os projetistas utilizam o mesmo tipo de software para desenho eletrônico, ou que os arquivos eletrônicos possam ser intercambiáveis entre si.

A elaboração de projetos e documentos, além de planilhas para controle, é feita por meio de softwares comercialmente disponíveis (para desenho, edição de texto, geração de gráfico ou planilha) e não integrados entre si. O armazenamento e distribuição dos documentos gerados ao longo do processo são feitos por meio de ferramenta de extranet ${ }^{70}$.

O Manual é, de modo geral, concebido para servir de guia para coordenadores de projeto externos à equipe da incorporadora, uma vez que a equipe interna supervisiona a gestão do processo de projeto por meio de sistemáticas pré-definidas junto a este coordenador, tais como: relatórios de acompanhamento, homologação de projetos, reuniões, etc.

Outras ferramentas utilizadas para fins de controle interno são: fichas de controle para esclarecimento técnico, formulário de avaliação de projetista, formulário de solicitação de pagamento, relatório de acompanhamento de desenvolvimento de projeto e relatórios de vistoria aos mock-ups. Além disso, uma metodologia própria para estabelecer parâmetros de custo de projeto está em processo de implantação, com o objetivo de permitir uma avaliação veloz dos valores necessários e possíveis para cada empreendimento.

${ }^{70}$ Ver item 3.1.2 do Capítulo C. 


\section{EMPREENDIMENTOS}

\subsection{EMPREENDIMENTO 1}

O empreendimento 1 trata de um projeto comercial de alto padrão na cidade do Rio de Janeiro, RJ, constituído por duas torres de escritório e um bloco de lojas e garagens (Figura 76). As torres têm 33 andares para utilização comercial e são parcialmente geminadas, enquanto que o bloco de lojas e garagens conta com cinco pavimentos, além dos cinco subsolos que atendem a todo o conjunto. A área construída total do empreendimento é de aproximadamente $170.000 \mathrm{~m}^{2}$, sendo cerca de $60.000 \mathrm{~m}^{2}$ para cada torre e $50.000 \mathrm{~m}^{2}$ para o restante.

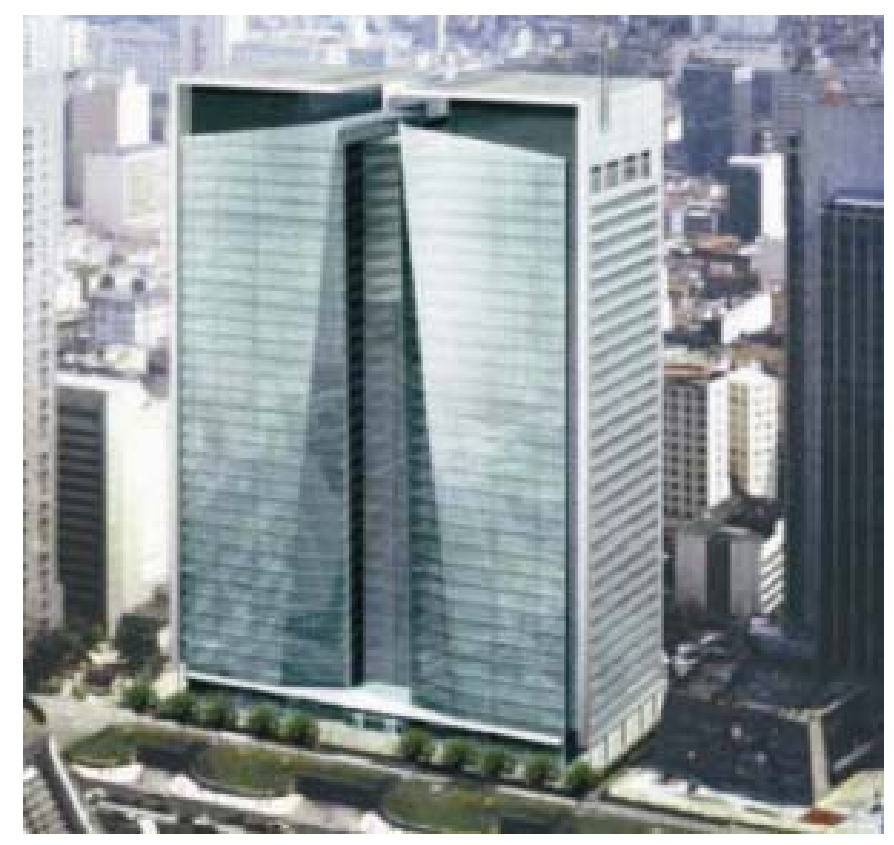

Figura 76 - Perspectiva ilustrada do empreendimento 1

Fonte: incorporadora em estudo

O estudo de viabilidade determinou a construção do empreendimento em etapas, o que definiu também o desenvolvimento do projeto. Na época do desenvolvimento deste trabalho, o empreendimento contava com todos os projetos executivos completos, uma torre e parte dos subsolos construídos, e outra torre com o restante dos subsolos em construção. 


\subsubsection{Dados técnicos}

\section{Arquitetura}

A organização espacial dos andares de escritórios constitui-se de planta livre com núcleo central (Figura 77), sendo a profundidade do andar entre 11,80m (menor) e 14,60m (maior), pé direito útil de $2,70 \mathrm{~m}$ e altura de piso a piso de $3,84 \mathrm{~m}$. Há a previsão de uso de forro acústico removível e piso elevado (Figura 78).

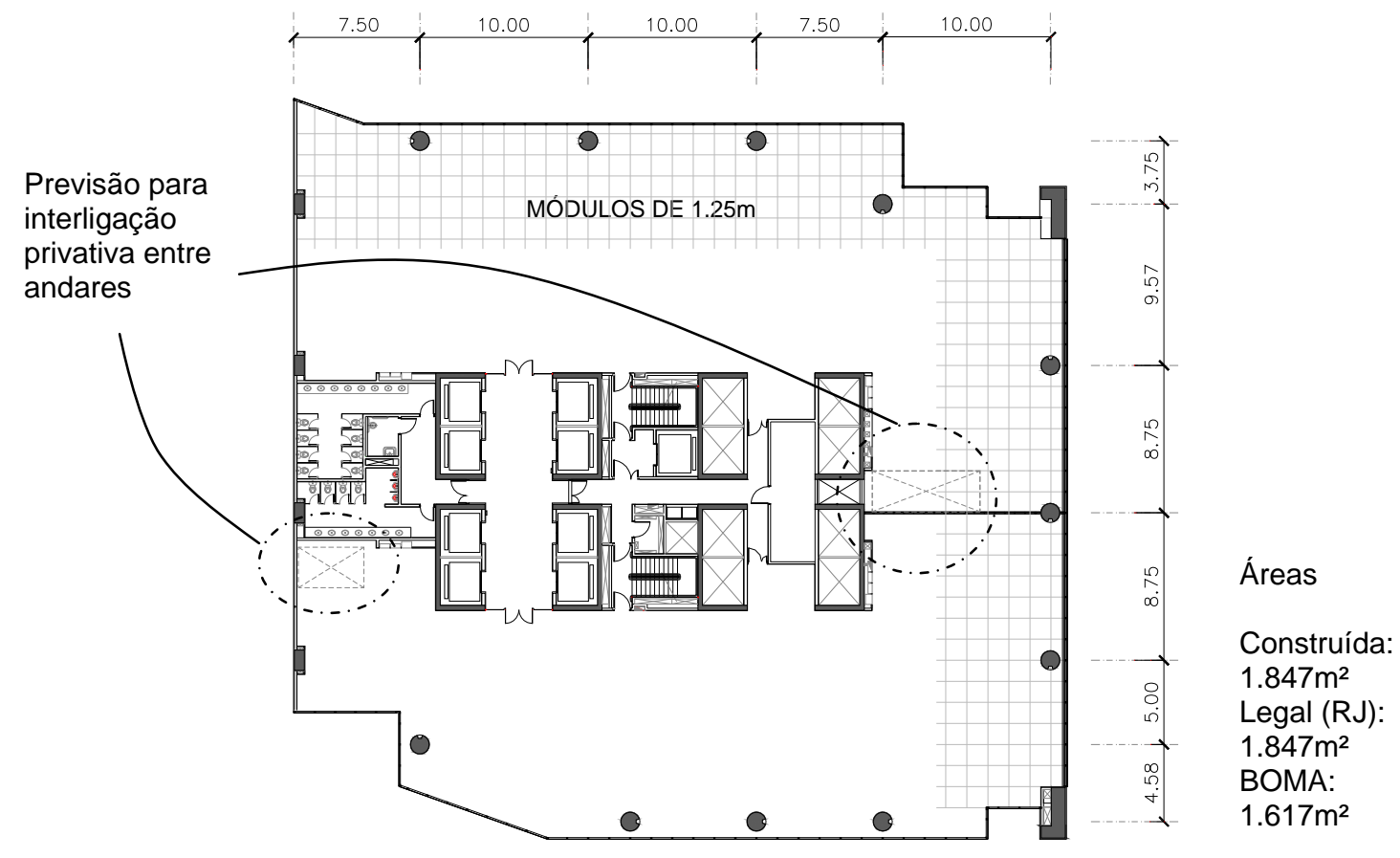

Figura 77 - Planta tipo (zona baixa) de uma torre do empreendimento 1 indicando: áreas, modulação estrutural (cotas) e modulação de arquitetura (módulos de 1,25m) Fonte da planta tipo: incorporadora em estudo

As fachadas frontal e posterior são fachadas-cortina; uma das laterais é uma fachada semicortina e a outra lateral, que faz posteriormente a interligação com a segunda torre, é uma vedação em alvenaria por conformação com revestimento aderido em massa e pintura acrílica $^{71}$. Os acabamentos das fachadas-cortina e semi-cortina são vidro emoldurado por placas de granito.

${ }^{71}$ Ver seção 1.3.1 do capítulo B. 


\section{Estrutura das torres}

A estrutura é reticulada em concreto armado, com pilares, lajes e vigas, sendo as lajes nervuradas e as vigas embutidas na altura das nervuras, resultando em uma altura estrutural de $40 \mathrm{~cm}$ nos pavimentos de escritórios. Algumas paredes estruturais no núcleo consolidam o travamento estrutural.

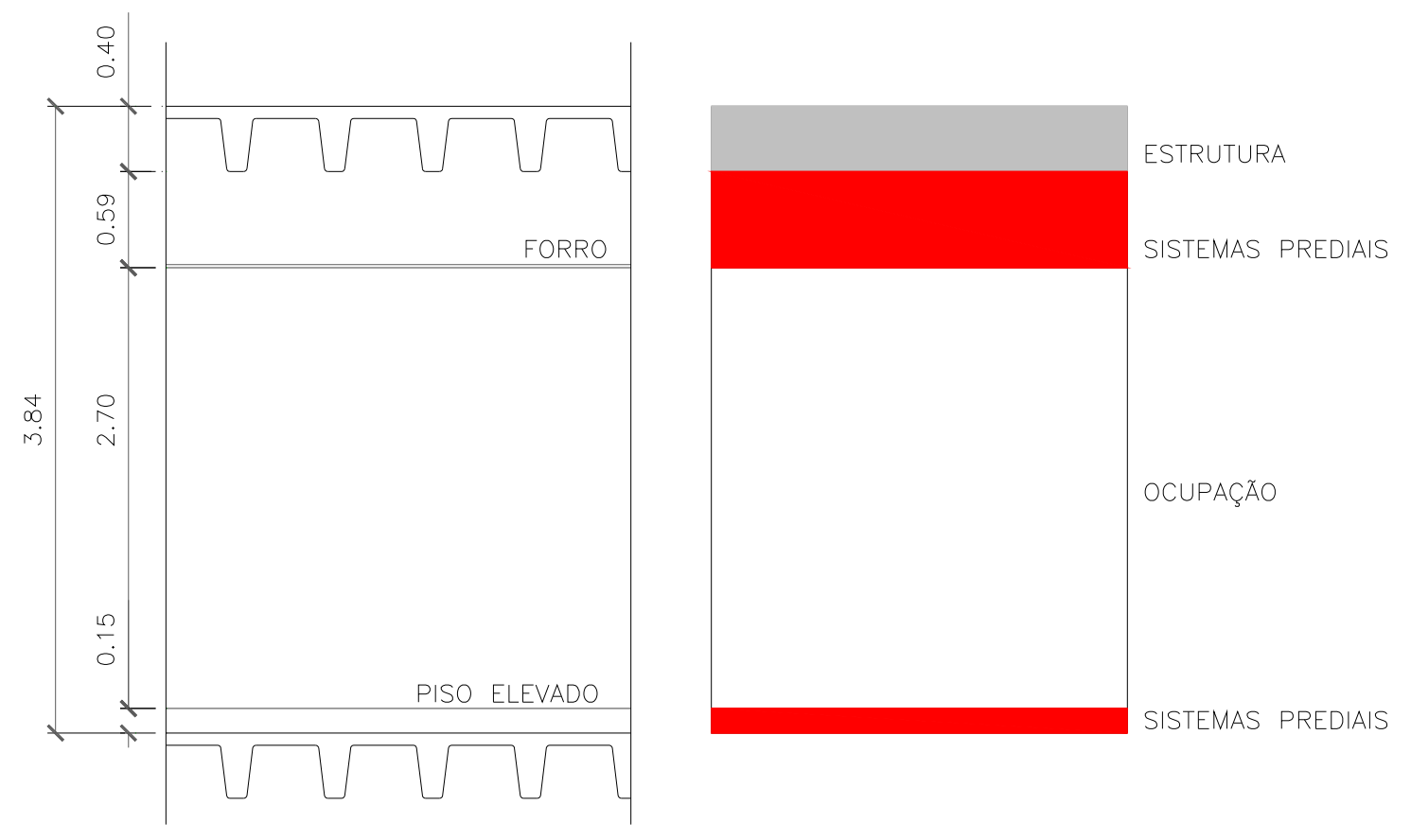

Figura 78 - Corte esquemático do empreendimento 1, indicando alturas e zoneamento vertical do andar tipo Fonte do corte: incorporadora em estudo

\section{Elevadores}

Cada torre conta com 17 elevadores distribuídos em zona alta e baixa, e mais quatro elevadores que servem exclusivamente aos subsolos.

\section{Sistemas mecânicos}

O sistema de ar condicionado é central de expansão indireta, todo-água, com central de água gelada e torre de resfriamento, localizadas na cobertura da torre, e unidades misturadoras $\left(A H U^{72} s\right)$ em cada pavimento de escritórios, no núcleo. A distribuição e o retorno do ar são feitos por meio de dutos no entreforro. Os sistemas localizados e específicos de condicionamento, como os de expansão direta, são previstos para algumas áreas técnicas e de administração predial. O sistema de pressurização de escadas conta com ventiladores nos subsolos com tomada de ar no térreo. O sistema de exaustão dos sanitários é feito por meio de dutos no núcleo e ventiladores na cobertura.

\footnotetext{
${ }^{72}$ Sigla para Air Handling Unit.
} 


\section{Sistemas prediais hidráulicos}

Os sistemas de água fria e combate a incêndios contam com a utilização de reservatórios inferior e superior, sendo o inferior localizado entre o $3^{\circ}$ e o $4^{\circ}$ subsolo, com capacidade de $344 \mathrm{~m}^{3}$, e o superior localizado na cobertura, com capacidade de $275 \mathrm{~m}^{3}$ (as capacidades referem-se ao consumo de apenas uma torre). O empreendimento conta ainda com reservatório de retardo de águas pluviais no $3^{\circ}$ subsolo e um reservatório de reuso, alimentado pelo sistema de drenagem do ar condicionado e pelas águas pluviais. A água de reuso é utilizada somente para irrigação e sistema de ar condicionado, e é distribuída por bombeamento.

\section{Espaços demandados pelos sistemas}

Os principais espaços demandados pelos sistemas prediais neste projeto, para uma torre com $60.000 \mathrm{~m}^{2}$ de área e subsolos com $20.000 \mathrm{~m}^{2}$, são apresentados na Tabela 8 , abaixo (valores aproximados e arredondados).

Tabela 8 - Espaços demandados para áreas técnicas do empreendimento 1

\begin{tabular}{|c|c|c|c|}
\hline Pavimentos & Sistemas mecânicos & $\begin{array}{c}\text { Sistemas } \\
\text { hidráulicos }\end{array}$ & $\begin{array}{c}\text { Sistemas elétricos e } \\
\text { outros }\end{array}$ \\
\hline Caixa d’água & $\begin{array}{l}\text { - Ventiladores WC e } \\
\text { extração fumaça } 50 \mathrm{~m}^{2}\end{array}$ & - Reservatório $190 \mathrm{~m}^{2}$ & Subestação $50 \mathrm{~m}^{2}$ \\
\hline $\begin{array}{l}\text { Casa de } \\
\text { máquinas } \\
\text { cobertura }\end{array}$ & $\begin{array}{l}\text { - Torres de resfriamento, } \\
\text { chillers, bombas e } \\
\text { ventiladores } 600 \mathrm{~m}^{2}\end{array}$ & & Subestação 70m² \\
\hline Pavimentos tipo & - Sala para AHU 23m² & & $\begin{array}{l}\text { Sala de elétrica } 5 \mathrm{~m}^{2} \\
\text { Armários para quadros e } \\
\text { automação } 5 \mathrm{~m}^{2}\end{array}$ \\
\hline $\begin{array}{l}\text { Embasamento (5 } \\
\text { subsolos) }\end{array}$ & $\begin{array}{l}\text { - Ventiladores } \\
\text { pressurização escadas } \\
100 \mathrm{~m}^{2} \\
\text { - Ventiladores exaustão } \\
\text { subsolos } 300 \mathrm{~m}^{2} \\
\text { - Ventiladores e } \\
\text { condicionadores } 80 \mathrm{~m}^{2}\end{array}$ & $\begin{array}{l}\text { - Reservatórios água } \\
\text { potável } 156 \mathrm{~m}^{2} \\
\text { - Reservatório água } \\
\text { retardo } 18 \mathrm{~m}^{2} \\
\text { - Reservatório reuso } \\
15 \mathrm{~m}^{2} \\
\text { - Casas de bombas } \\
75 \mathrm{~m}^{2}\end{array}$ & $\begin{array}{l}\text { Subestação } 90 \mathrm{~m}^{2} \\
\text { Cabine de medição } 80 \mathrm{~m}^{2} \\
\text { QGBT } 45 \mathrm{~m}^{2} \\
\text { No break } 8 \mathrm{~m}^{2} \\
\text { DG } 10 \mathrm{~m}^{2} \\
\text { Central de segurança } \\
50 \mathrm{~m}^{2}\end{array}$ \\
\hline
\end{tabular}

\subsubsection{Gestão de interfaces}

A formatação do negócio deste projeto foi realizada de tal forma que a presença da construtora na gestão do processo de projeto ocorreu desde o início, sendo que todas as 
estimativas de custos e orçamentos tiveram seu envolvimento direto, além das análises de viabilidade construtiva das soluções técnicas.

A incorporadora definiu a contratação dos projetistas e consultores (Tabela 9), sendo que a coordenação de projetos ficou a cargo do escritório de arquitetura, autor do projeto (Figura 79). Assim, a incorporadora ficou com a função de gerenciar administrativamente os contratos dos projetos (controlar pagamentos, definir limites orçamentários das soluções técnicas, aprovar as etapas) e o escritório de arquitetura ficou com a parte operacional da coordenação do processo de projeto (convocar reuniões, redigir atas, elaborar cronogramas, controlar datas de recebimento de projetos, entre outros).

Tabela 9 - Projetistas e consultores do empreendimento 1 (em ordem alfabética de especialidade)

\begin{tabular}{lll}
\hline Acústica & Comunicação visual & Impermeabilização \\
\hline $\begin{array}{l}\text { Ar condicionado e sistemas } \\
\text { mecânicos }\end{array}$ & $\begin{array}{c}\text { Consultor de segurança pessoal } \\
\text { (NFPA) }\end{array}$ & Irrigação \\
\hline Arquitetura & $\begin{array}{c}\text { Consultor de tráfego (geometria } \\
\text { das vias de acesso) }\end{array}$ & Luminotécnica \\
\hline Automação & Consultor de heliponto & Paisagismo \\
\hline Combate a incêndio & Estrutura de concreto & Segurança patrimonial \\
\hline Caixilharia & Estrutura metálica & $\begin{array}{c}\text { Sistemas prediais (elétrica e } \\
\text { hidráulica) }\end{array}$ \\
\hline Consultor de fachada & $\begin{array}{c}\text { Equipamento de limpeza de } \\
\text { fachada }\end{array}$ & Sinalização dos subsolos \\
\hline Consultor de sistemas prediais & Fundações & Vedações \\
\hline
\end{tabular}

Na opinião de representantes do Departamento de P\&C, o funcionamento deste arranjo no projeto foi considerado satisfatório, uma vez que o processo ocorreu sem grandes sobressaltos. Atribuiu-se este resultado, em parte, ao conhecimento prévio que o escritório de arquitetura tinha dos processos da incorporadora, por ter desenvolvido outros projetos anteriores com ela, e, em parte, ao perfil pessoal do coordenador de projetos designado para este processo. 


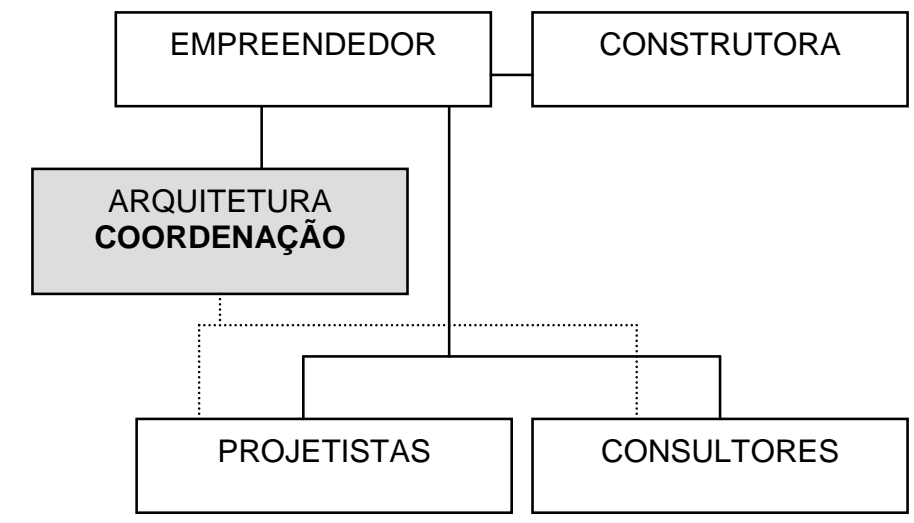

- Gerenciamento administrativo

Coordenação técnica

Figura 79 - Arranjo entre os principais agentes do processo de projeto do empreendimento 1

\subsubsection{Certificação ambiental}

O projeto do empreendimento 1 teve o objetivo, entre outros, de obter a certificação ambiental do padrão $L E E D^{73}$. Na ótica da incorporadora, a certificação ambiental representa uma poderosa ferramenta mercadológica, e apesar de demandar um investimento adicional nos custos de projeto e execução traz um desempenho posterior na operação e manutenção do empreendimento que se traduz em economia de recursos. Por este motivo, grande parte de seus edifícios comerciais, nos quais ela também é responsável por esta etapa de manutenção, tem a certificação ambiental como parâmetro de projeto. O fato da matriz da empresa ter origem norte-americana explica a preferência pelo programa de certificação LEED.

O projeto do empreendimento 1 apresenta a certificação LEED nível Ouro para a categoria CS (Core\& Shell).

${ }^{73}$ Ver seção 3.5 do capítulo C. 


\subsection{EMPREENDIMENTO 2}

O empreendimento 2 trata de um projeto comercial de alto padrão no município de Barueri, $\mathrm{SP}$, constituído por seis torres de escritório e um centro de compras associado a um edifício garagem. As torres 1, 2 e 3 são idênticas, contam com 14 pavimentos para ocupação de escritórios e área construída aproximada de $35.800 \mathrm{~m}^{2}$ cada. A torre 4 conta com 18 pavimentos e área construída aproximada de $30.000 \mathrm{~m}^{2}$; a torre 5,23 pavimentos e área de $62.000 \mathrm{~m}^{2}$; a torre 6, 26 pavimentos e área de $70.000 \mathrm{~m}^{2}$; e o centro de compras com o edifício garagem, 6 pavimentos e $164.000 \mathrm{~m}^{2}$. Somando estas áreas ao subsolo que atende as torres 4,5 e 6 , a área construída total do empreendimento tem um valor próximo de $535.000 \mathrm{~m}^{2}$.

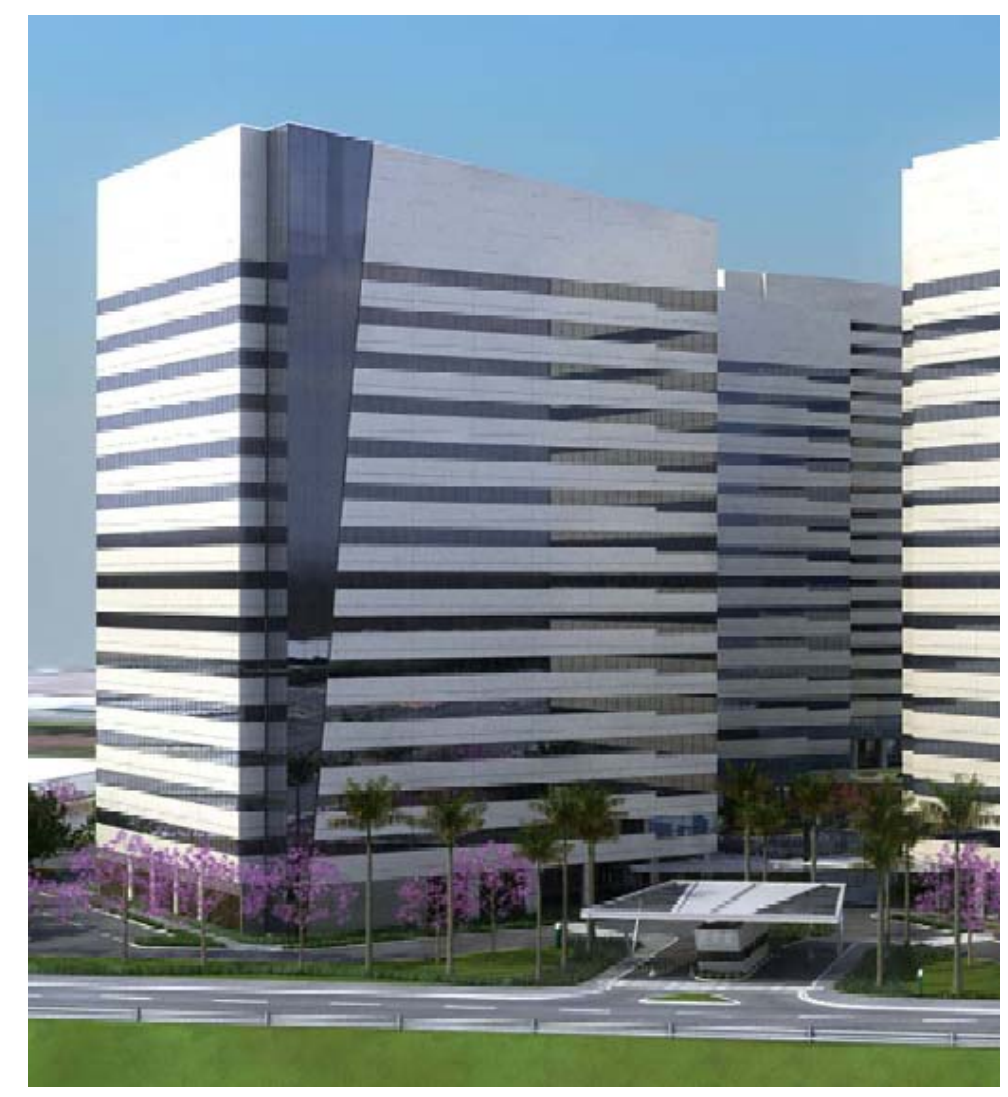

Figura 80 - Perspectiva ilustrada de uma torre do empreendimento 2 Fonte: incorporadora em estudo 
A magnitude do empreendimento foi um dos fatores determinantes para a decisão do desenvolvimento do projeto e da execução de obras em etapas. $\mathrm{Na}$ época do desenvolvimento deste trabalho, o empreendimento contava com o projeto executivo completo para as torres 1, 2 e 3; projeto executivo em desenvolvimento do centro comercial e edifício garagem; e projeto básico em desenvolvimento das demais torres. Além disso, a torre 1 (Figura 80) e parte da implantação para o funcionamento desta estavam em construção.

Para fins deste estudo, adotou-se a coleta dos dados técnicos da torre 1, por representar o padrão mais repetido dentro do empreendimento e por apresentar a documentação de projetos mais completa.

\subsubsection{Dados técnicos}

\section{Arquitetura}

A organização espacial dos andares de escritórios constitui-se de planta livre com núcleo central (Figura 81), sendo a profundidade do andar entre 13,70m (menor) e 15,25m (maior), pé direito útil de $2,75 \mathrm{~m}$ e altura de piso a piso de $4,10 \mathrm{~m}$. Há a previsão de uso de forro acústico removível e piso elevado (Figura 82). As fachadas são vedações verticais por acoplamento a seco com revestimento incorporado ${ }^{74}$, em painéis pré-fabricados de concreto armado, e a fachada principal apresenta um detalhe em pele de vidro, caracterizando um trecho em fachada-cortina.

\section{Estrutura}

A estrutura é reticulada em concreto armado, com pilares, lajes e vigas, sendo as lajes com $15 \mathrm{~cm}$ de espessura e as vigas com $95 \mathrm{~cm}$ de altura, incluindo a viga de borda. $O$ posicionamento delas é feito de forma que as grandes passagens dos sistemas prediais sejam evitadas e as distribuições sejam feitas por meio de furos nas vigas, com altura máxima de $40 \mathrm{~cm}$ por furo. Algumas paredes estruturais no núcleo consolidam o travamento estrutural.

\footnotetext{
${ }^{74}$ Ver seção 1.3.1 do capítulo B.
} 


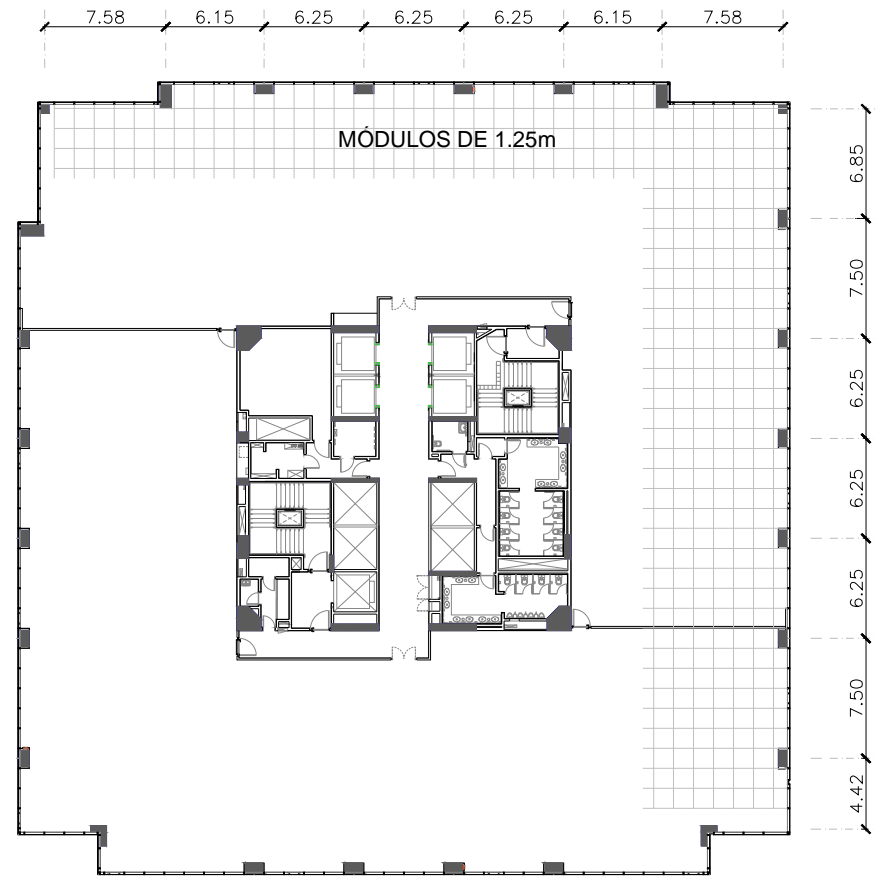

Áreas

Construída:

$2.312 \mathrm{~m}^{2}$

Legal (Barueri):

$2.234 \mathrm{~m}^{2}$

BOMA:

$2.174 \mathrm{~m}^{2}$

Figura 81 - Planta tipo (zona baixa) de uma torre do empreendimento 2

indicando: áreas, modulação estrutural (cotas) e modulação de arquitetura (módulos de 1,25m)

Fonte da planta tipo: incorporadora em estudo

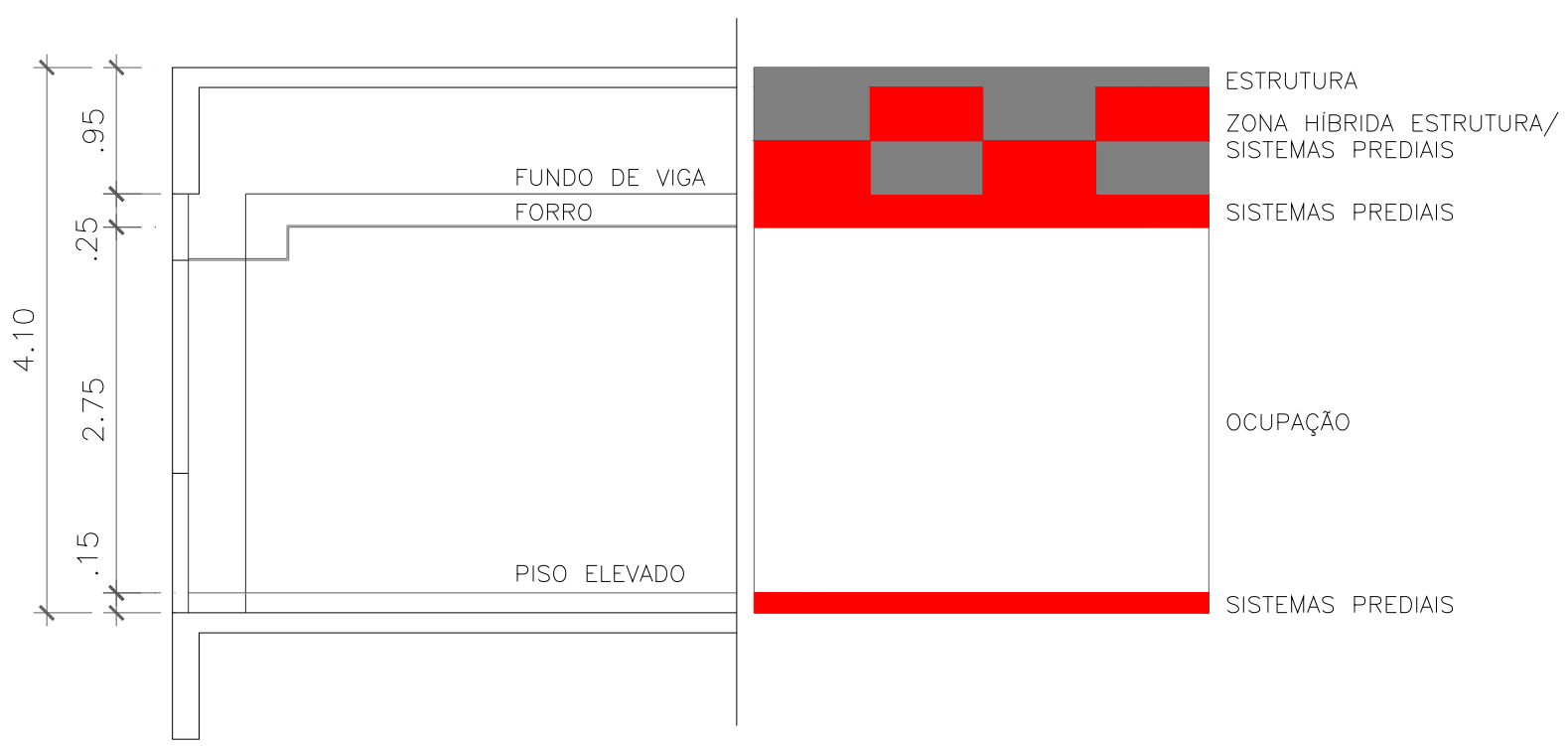

Figura 82 - Corte esquemático do empreendimento 2, indicando alturas e zoneamento vertical do andar tipo Fonte do corte: incorporadora em estudo 


\section{Elevadores}

Cada torre conta com nove elevadores distribuídos em zona alta e baixa.

\section{Sistemas mecânicos}

O sistema de ar condicionado é central do tipo ar-água, sendo a geração do ar frio por expansão direta no núcleo do andar, feita por meio de equipamento conhecido como selfcontained, e o resfriamento da água por meio de torre de resfriamento localizada na cobertura do edifício. A distribuição e retorno do ar são feitos por meio de dutos no entreforro, sendo que a captação de ar externo é feita por meio de ventiladores na cobertura. Os sistemas localizados e específicos de condicionamento, como os de expansão direta, são previstos para algumas áreas técnicas, como, por exemplo, a casa de máquinas dos elevadores. O sistema de pressurização de escadas conta com ventiladores no pavimento técnico (mezanino do térreo) e o sistema de exaustão dos sanitários é feito por meio de dutos no núcleo e ventiladores na cobertura.

\section{Espaços demandados pelos sistemas}

Os principais espaços demandados pelos sistemas prediais neste projeto, para a torre tipo 1, são apresentados na Tabela 10, abaixo (valores aproximados e arredondados).

Tabela 10 - Espaços demandados para áreas técnicas do empreendimento 2

\begin{tabular}{|c|c|c|c|}
\hline Pavimentos & Sistemas mecânicos & $\begin{array}{c}\text { Sistemas } \\
\text { hidráulicos }\end{array}$ & $\begin{array}{c}\text { Sistemas elétricos e } \\
\text { outros }\end{array}$ \\
\hline Ático & $\begin{array}{l}\text { - Ventiladores WC } 25 \mathrm{~m}^{2} \\
\text { - Tomada de ar externo } \\
40 \mathrm{~m}^{2} \\
\text { - Torres de resfriamento, } \\
\text { reservatório de reposição } \\
\text { de água e bombas } 300 \mathrm{~m}^{2} \\
\end{array}$ & & $\begin{array}{l}\text { - Medição } 70 \mathrm{~m}^{2} \\
\text { - Sala de } \\
\text { telecomunicações } 10 \mathrm{~m}^{2}\end{array}$ \\
\hline Pavimentos tipo & - Sala para self $40 m^{2}$ & & $\begin{array}{l}\text { - Sala de elétrica } 10 \mathrm{~m}^{2} \\
\text { - Sala de sistemas } 7 \mathrm{~m}^{2} \\
\text { - Armários para quadros } \\
7 \mathrm{~m}^{2}\end{array}$ \\
\hline $\begin{array}{l}\text { Pavimento } \\
\text { mecânico } \\
\text { (mezanino do } \\
\text { tipo) }\end{array}$ & $\begin{array}{l}\text { - Sala para self } \\
\text { (administração no térreo) } \\
40 m^{2} \\
\text { - Sala para self (central de } \\
\text { segurança) } 3 m^{2}\end{array}$ & & $\begin{array}{l}\text { - Sala de elétrica } 10 \mathrm{~m}^{2} \\
\text { - Sala de sistemas } 7 \mathrm{~m}^{2} \\
\text { - Central de segurança } \\
60 \mathrm{~m}^{2} \\
\text { - UPS } 7 \mathrm{~m}^{2}\end{array}$ \\
\hline Térreo & $\begin{array}{l}\text { - Ventiladores } \\
\text { pressurização escadas } \\
40 \mathrm{~m}^{2} \\
\text { - Sala para self (área do } \\
\text { lobby) } 40 \mathrm{~m}^{2}\end{array}$ & $\begin{array}{l}\text { - Reservatórios água } \\
\text { potável } 100 m^{2} \\
\text { - Reservatório reuso } \\
75 m^{2} \\
\text { - Casas de bombas } \\
30 m^{2}\end{array}$ & $\begin{array}{l}\text { - Subestação } 60 \mathrm{~m}^{2} \\
\text { - Sala de elétrica } 10 \mathrm{~m}^{2} \\
\text { - Sala de sistemas } 7 \mathrm{~m}^{2} \\
\text { - Gerador } 90 \mathrm{~m}^{2} \\
\text { - DG } 40 \mathrm{~m}^{2}\end{array}$ \\
\hline
\end{tabular}




\section{Sistemas prediais hidráulicos}

O sistema de água fria e combate a incêndios conta com a utilização de reservatório inferior, localizado no térreo, fora da projeção da torre, com capacidade de $450 \mathrm{~m}^{3}$, sendo a distribuição para os pavimentos por meio de bombas de pressurização. Há previsão de reservatório de reuso no térreo, no mesmo abrigo do reservatório de água fria, alimentado pelo sistema de drenagem do ar condicionado, pelas águas cinzas (lavatórios e chuveiros), e pelas águas pluviais. A água de reuso é utilizada para abastecer mictórios, bacias sanitárias, sistema de ar condicionado e irrigação; é distribuída por bombeamento; e seu sistema conta com elementos pré-filtrantes (caixa de areia) e dosador de cloro.

\subsubsection{Gestão de interfaces}

A formatação do negócio deste projeto foi realizada de tal forma que a presença da construtora na gestão do processo de projeto ocorreu desde o início, sendo que todas as estimativas de custos e orçamentos tiveram seu envolvimento direto, além das análises de viabilidade construtiva das soluções técnicas.

A incorporadora definiu a contratação dos projetistas e consultores (Tabela 11), sendo que a coordenação de projetos ficou a cargo de uma empresa especializada. Assim, a incorporadora ficou com a função de gerenciar administrativamente os contratos dos projetos e a empresa "terceirizada" ficou com a coordenação do processo de projeto (Figura 83).

Tabela 11 - Projetistas e consultores do empreendimento 2 (em ordem alfabética de especialidade)

\begin{tabular}{|c|c|c|}
\hline Acústica & Consultor de sistemas prediais & Luminotécnica \\
\hline $\begin{array}{l}\text { Ar condicionado e sistemas } \\
\text { mecânicos }\end{array}$ & Consultor de pedras naturais & Pavimentação \\
\hline Arquitetura & Coordenação de projetos & Paisagismo \\
\hline Automação & Comunicação visual & Pré-moldados \\
\hline Combate a incêndio & Estrutura de concreto & Segurança patrimonial \\
\hline Caixilharia & Estrutura metálica & $\begin{array}{l}\text { Sistemas prediais (elétrica e } \\
\text { hidráulica) }\end{array}$ \\
\hline Consultor de acessibilidade & Fundações & Vedações \\
\hline Consultor de fachada & Impermeabilização & \\
\hline Consultor de estacionamento & Irrigação & \\
\hline
\end{tabular}




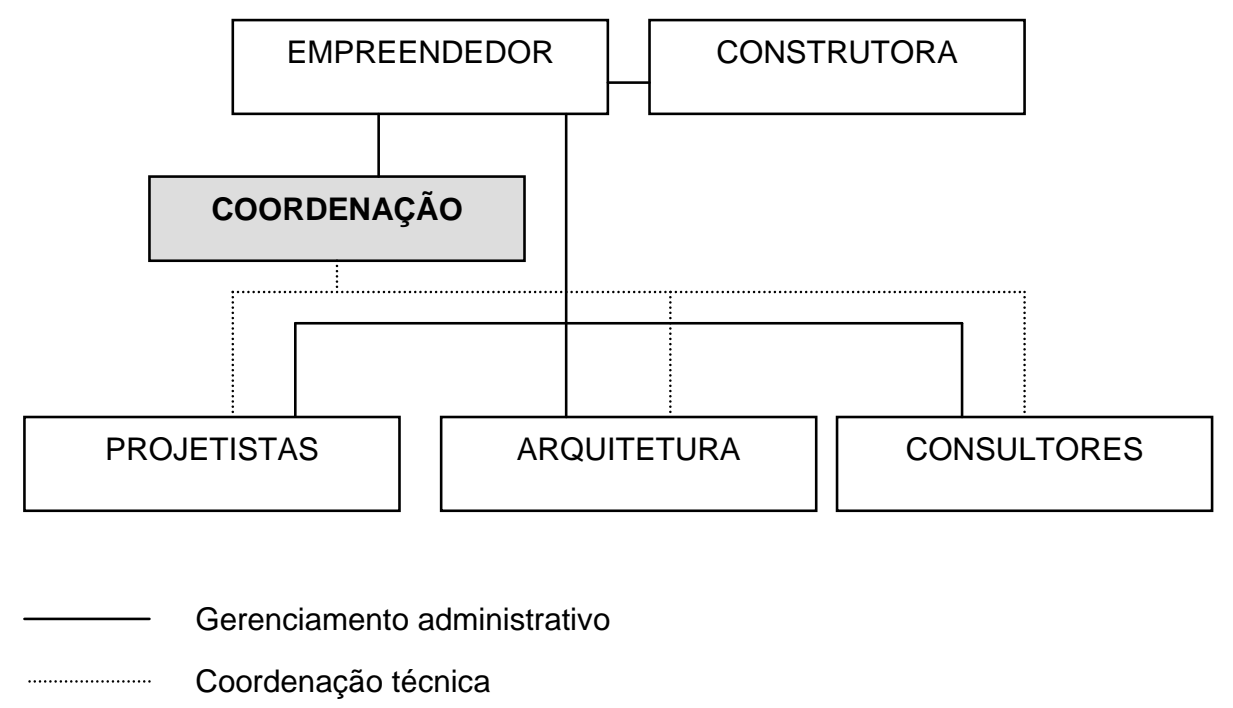

Figura 83 - Arranjo entre os principais agentes do processo de projeto do empreendimento 2

Este arranjo, envolvendo uma coordenação de projetos externa, teve caráter experimental e tinha como objetivo mitigar eventuais dificuldades com o escritório de arquitetura, pois era o primeiro projeto desta em conjunto com a incorporadora. De fato, houve certa dificuldade por parte do escritório de arquitetura na adaptação aos procedimentos formais previstos no processo da incorporadora, além da falta de entrosamento entre a arquitetura e a coordenação.

$\mathrm{Na}$ opinião de representantes do Departamento de P\&C, a coordenação externa pouco ajudou, tanto na melhoria deste aspecto, quanto na abordagem à principal dificuldade enfrentada no processo de projeto deste empreendimento: a compatibilização dos projetos. Embora esta atividade fosse inerente a todas as disciplinas, além da própria arquitetura, não ficou claro com qual agente estava a responsabilidade sobre ela nos escopos de contratação. A expectativa por parte da incorporadora quanto à eficiência e eficácia deste arranjo no processo do projeto, neste caso, não se concretizou.

\subsubsection{Certificação ambiental}

Este empreendimento não apresenta certificação ambiental pelo fato de uma parte dos investidores não estar disposta a arcar com os eventuais acréscimos de custos no projeto e construção oriundos desta certificação. 


\subsection{EMPREENDIMENTO 3}

O empreendimento 3 trata de um projeto comercial de alto padrão no município de Brasília, DF, constituído por duas torres de escritório e lojas comerciais. As torres são idênticas, contam com 19 pavimentos para ocupação de escritórios e área construída aproximada de $48.000 \mathrm{~m}^{2}$ cada. As lojas comerciais e o estacionamento de veículos estão localizados no embasamento comum entre as torres, que, além do térreo, conta com quatro subsolos e um pavimento semi-enterrado. A área construída total do empreendimento gira em torno de $192.000 \mathrm{~m}^{2}$.

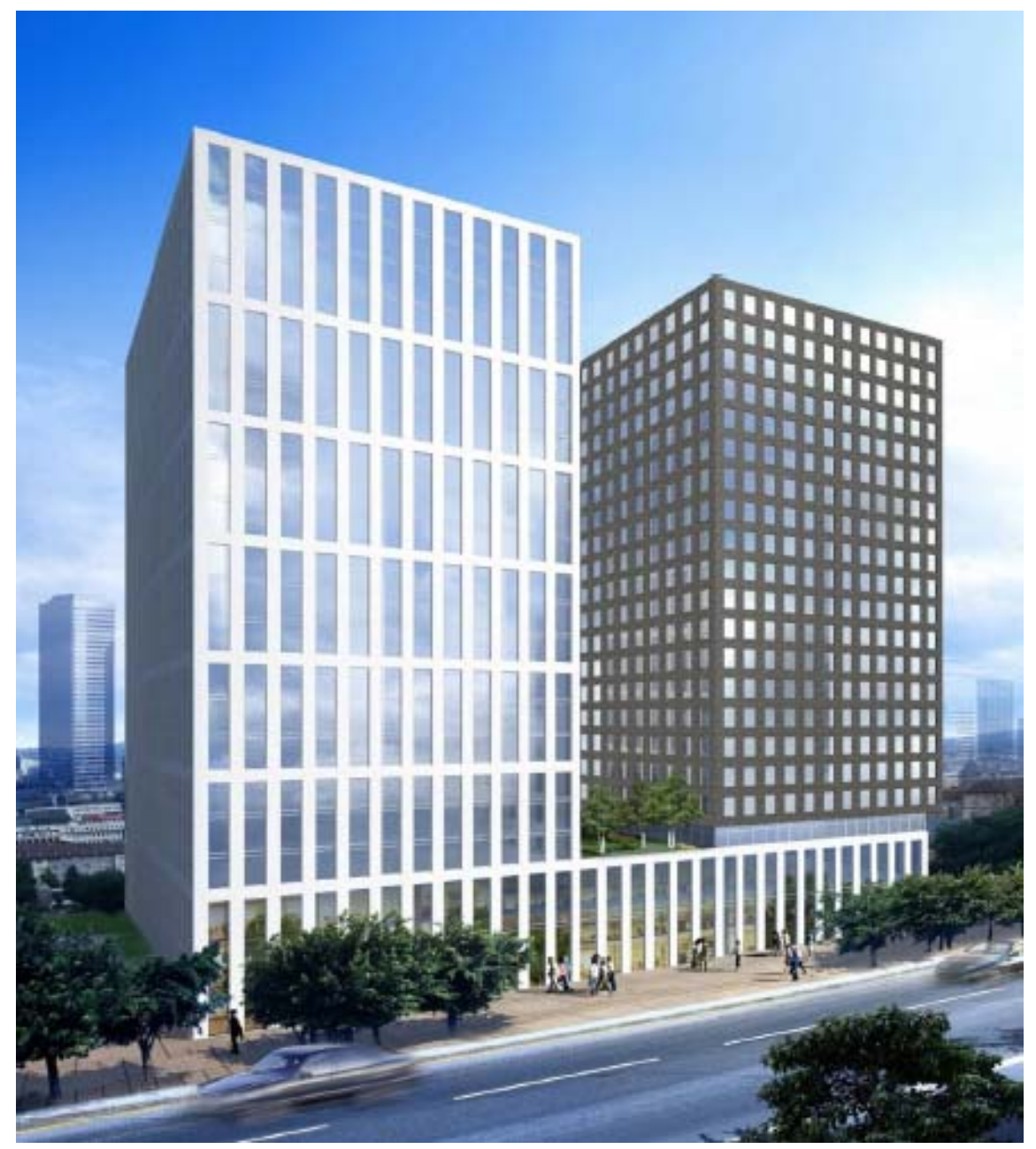

Figura 84 - Perspectiva ilustrada do empreendimento 3

Fonte: incorporadora em estudo 
$\mathrm{Na}$ época do desenvolvimento deste trabalho, o processo de projeto do empreendimento contava com o projeto básico completo de todas as disciplinas e passava por uma fase de retroalimentação e transição de programa, em virtude de um retorno negativo na aprovação legal do município. Este retorno obrigou que o processo fosse retomado de seu início. Para este trabalho, optou-se por apresentar as informações disponíveis do projeto básico já desenvolvido, em função da quantidade e da facilidade de acesso a estas informações.

\subsubsection{Dados técnicos do pavimento tipo}

\section{$\underline{\text { Arquitetura }}$}

A organização espacial dos andares de escritórios constitui-se de planta livre com núcleo central (Figura 85), sendo a profundidade do andar entre 11,90m (menor) e 17,70m (maior), pé direito útil de 2,70m e altura de piso a piso de 3,90m. Há a previsão para uso de forro acústico removível e piso elevado (Figura 86). As fachadas são do tipo cortina, com revestimentos de vidro e pedra natural.

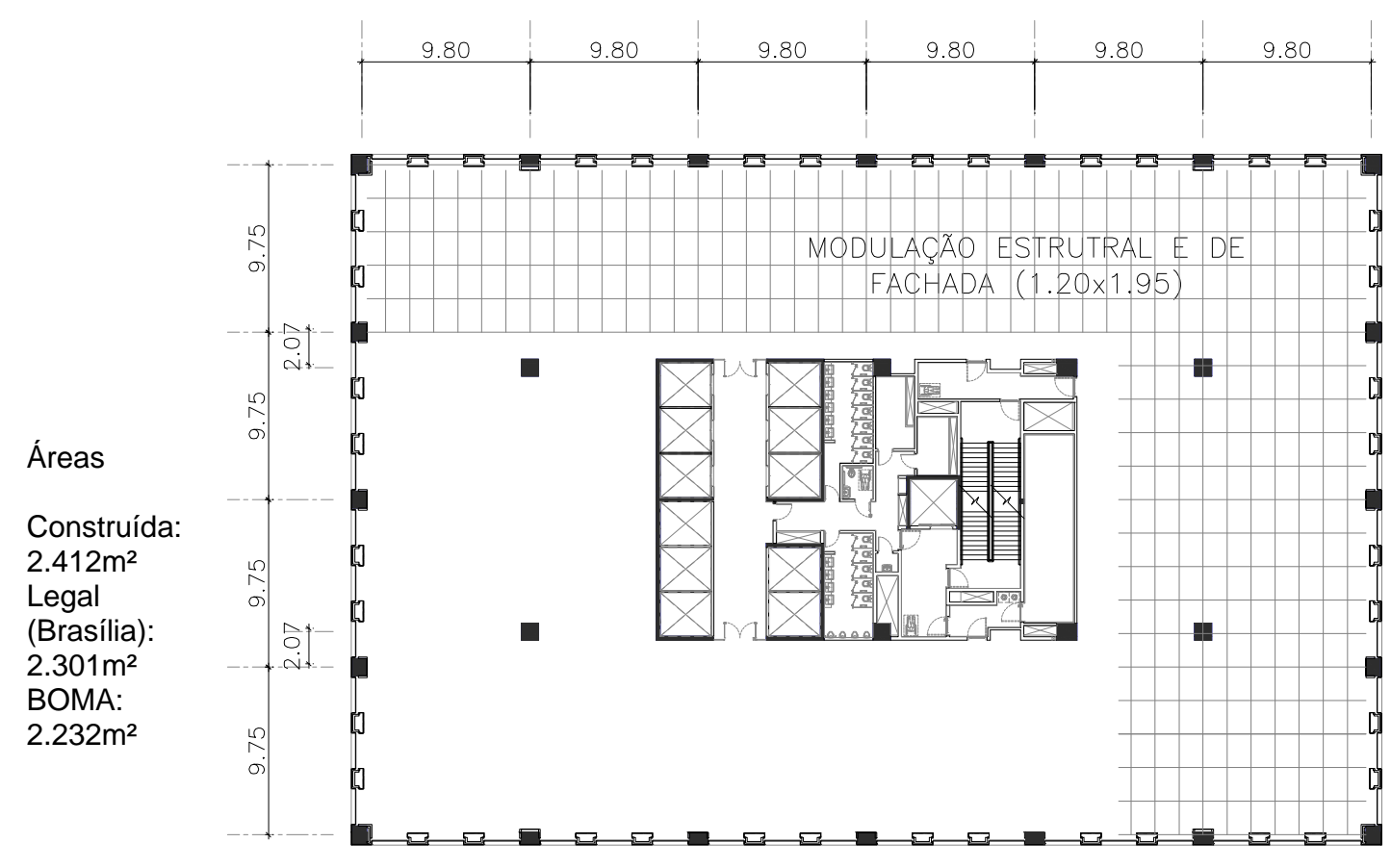

Figura 85 - Planta tipo (zona baixa) de uma torre do empreendimento 3

indicando: áreas, modulação estrutural (cotas) e modulação de arquitetura. O encaixe da modulação do forro acústico $(1,25 \times 1,25 \mathrm{~m})$ é feito por meio de forro de gesso customizado na periferia do andar

Fonte da planta tipo: incorporadora em estudo 


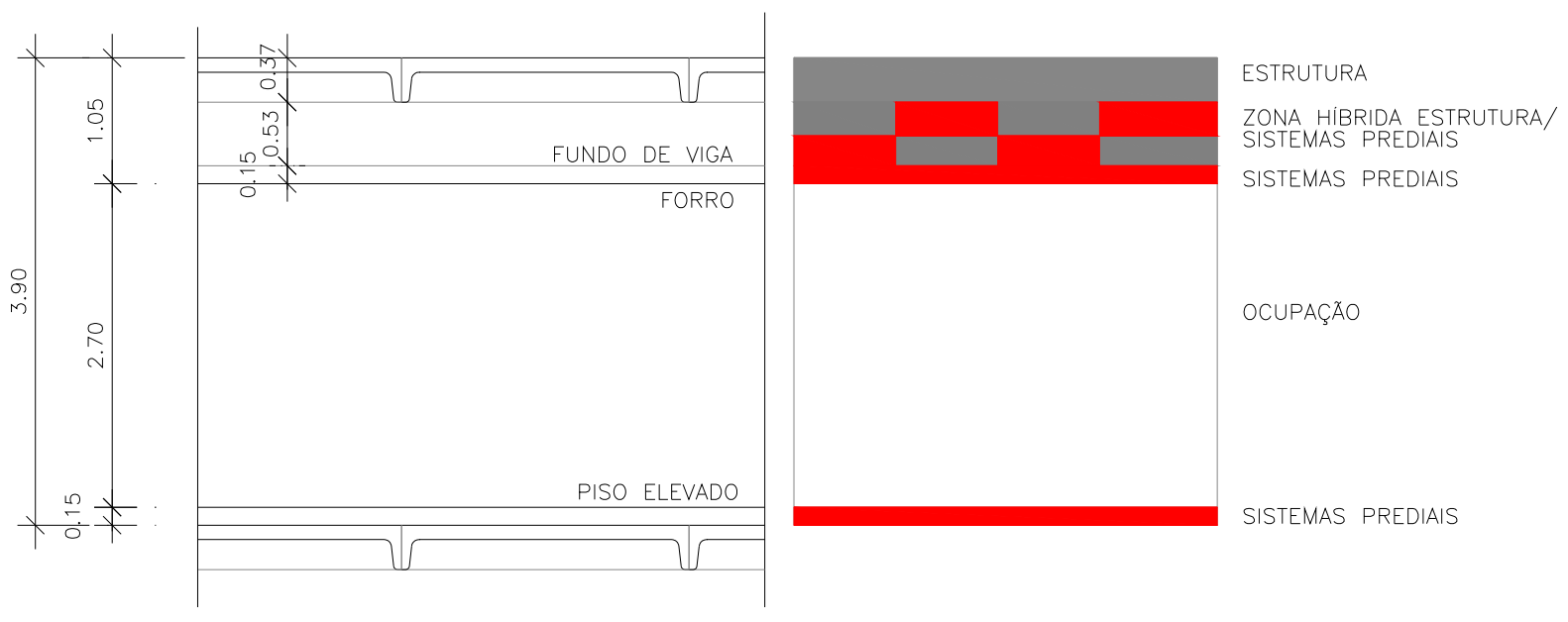

Figura 86 - Corte esquemático do empreendimento 3, indicando alturas e zoneamento vertical do andar tipo Fonte do corte: incorporadora em estudo

\section{Estrutura}

A estrutura é reticulada em concreto armado, com pilares, lajes e vigas, sendo as lajes do tipo nervuradas com $37 \mathrm{~cm}$ de espessura. As vigas no sentido transversal (que atendem o lado do andar com profundidade de $11.90 \mathrm{~m}$ ) são embutidas na altura da laje e protendidas, enquanto que as vigas no sentido longitudinal têm $90 \mathrm{~cm}$ de altura e contam com pilares intermediários, dispensando a protensão. A viga de borda tem altura de $105 \mathrm{~cm}$. Algumas paredes estruturais no núcleo consolidam o travamento estrutural.

\section{Elevadores}

Cada torre conta com 12 elevadores distribuídos em zona alta e baixa, além do elevador de emergência, que atende a todos os andares.

\section{Sistemas mecânicos}

O sistema de ar condicionado é central de expansão indireta, todo-água, com central de água gelada e torre de resfriamento localizadas na cobertura da torre, e unidades misturadoras (AHUs) em cada pavimento de escritórios, no núcleo. A distribuição e retorno do ar são feitos por meio de dutos no entreforro, e a captação de ar externo é feita por meio de ventiladores na cobertura e controlada por sensores de qualidade do ar interno (sensor de $\mathrm{CO}_{2}$ ). Na cobertura também está localizado um recuperador de calor do ar de exaustão, 
conhecido como roda entálpica, com a finalidade de melhorar o desempenho de funcionamento do sistema.

O sistema de pressurização de escadas conta com ventiladores no pavimento semienterrado e o sistema de exaustão dos sanitários é feito por meio de dutos no núcleo e ventiladores na cobertura.

\section{Espaços demandados pelos sistemas}

Os principais espaços demandados pelos sistemas prediais neste projeto, para uma torre e metade dos susbsolos, são apresentados na Tabela 12, abaixo (valores aproximados e arredondados).

Tabela 12 - Espaços demandados para áreas técnicas do empreendimento 3, para uma torre

\begin{tabular}{|c|c|c|c|}
\hline Pavimentos & Sistemas mecânicos & $\begin{array}{c}\text { Sistemas } \\
\text { hidráulicos }\end{array}$ & $\begin{array}{c}\text { Sistemas elétricos e } \\
\text { outros }\end{array}$ \\
\hline Ático & $\begin{array}{l}\text { - Tomada de ar externo, } \\
\text { ventiladores de exaustão, } \\
\text { roda entálpica } 80 \mathrm{~m}^{2} \\
\text { - Sala equipamento } 40 \mathrm{~m}^{2} \\
\text { - Torres de resfriamento, } \\
\text { reservatório de reposição } \\
\text { de água e bombas } 400 \mathrm{~m}^{2} \\
\text { - Roda entálpica e } \\
\text { ventiladores } 80 \mathrm{~m}^{2} \text { (a roda } \\
\text { entálpica ocupa quase } 2 \\
\text { andares em altura) }\end{array}$ & & $\begin{array}{l}\text { - Sala de elétrica } 10 m^{2} \\
\text { - Sala de telecom } 8 m^{2}\end{array}$ \\
\hline Pavimentos tipo & - Sala para AHU 40m² & & $\begin{array}{l}\text { - Sala de elétrica } 10 \mathrm{~m}^{2} \\
\text { - Sala de telecom } 8 \mathrm{~m}^{2} \\
\text { - Armários para quadros } \\
5 \mathrm{~m}^{2}\end{array}$ \\
\hline $\begin{array}{l}\text { Mezanino do } \\
\text { térreo (lojas) }\end{array}$ & - Sala para $A H U 70 m^{2}$ & & $\begin{array}{l}\text { - Sala de elétrica } 10 m^{2} \\
\text { - Sala de telecom } 8 m^{2}\end{array}$ \\
\hline Térreo & - Sala para AHU 70m² & & $\begin{array}{l}\text { - Sala de elétrica } 10 m^{2} \\
\text { - Sala de telecom } 8 m^{2}\end{array}$ \\
\hline $\begin{array}{l}\text { Pavimento semi- } \\
\text { enterrado }\end{array}$ & $\begin{array}{l}\text { - Ventiladores } \\
\text { pressurização escadas } \\
16 m^{2} \\
\text { - Ventiladores de exaustão } \\
\text { 80m² } \\
\text { - Sala de pressurização } \\
\text { 140m² } \\
\text { - Sala para self } \\
\text { (administração) 75m² } \\
\text { - Unidades resfriadoras } \\
\text { (chillers) e bombas } 190 \mathrm{~m}^{2}\end{array}$ & & $\begin{array}{l}\text { - Subestação e medição } \\
90 \mathrm{~m}^{2} \\
\text { - Sala de } \\
\text { telecomunicações } 100 \mathrm{~m}^{2}\end{array}$ \\
\hline Subsolos & $\begin{array}{l}\text { - Exaustão subsolos } 200 m^{2} \\
\text { - Ventiladores } 100 m^{2}\end{array}$ & $\begin{array}{l}\text { - Reservatórios água } \\
\text { potável 340m² } \\
\text { - ETE e reservatório } \\
\text { reuso } 470 m^{2} \\
\text { - Casas de bombas } \\
\text { 170m² }\end{array}$ & \\
\hline
\end{tabular}




\section{Sistemas prediais hidráulicos}

O sistema de água fria e combate a incêndios conta com a utilização de dois reservatórios inferiores, localizados no $3^{\circ}$ subsolo, um na projeção de cada torre, com capacidades somadas de $530 \mathrm{~m}^{3}$, sendo a distribuição para os pavimentos por meio de bombas de pressurização. Há previsão de reservatório de reuso no $3^{\circ}$ subsolo, alimentado pelo sistema de drenagem do ar condicionado, pelas águas cinzas (lavatórios e chuveiros), e pelas águas pluviais. A água de reuso é utilizada para abastecer mictórios, bacias sanitárias, sistema de ar condicionado e irrigação; é distribuída por bombeamento; e seu sistema conta com elementos pré-filtrantes (caixa de areia) e dosador de cloro.

\subsubsection{Gestão de interfaces}

O fato da construtora ser sócia no empreendimento garantiu sua presença na gestão do processo de projeto desde o início, sendo que todas as estimativas de custos e orçamentos tiveram o envolvimento direto dela, além de análises de viabilidade construtiva das soluções técnicas.

A incorporadora definiu a contratação dos projetistas e consultores (Tabela 13), sendo que a coordenação de projetos ficou a cargo do escritório de arquitetura, autor do projeto. Assim, a incorporadora ficou com a função de gerenciar administrativamente os contratos dos projetos e o escritório de arquitetura ficou com a coordenação do processo de projeto Esta última contratou uma empresa terceirizada para fazer o trabalho de coordenação e outra para fazer o detalhamento do projeto (Figura 87).

Tabela 13 - Projetistas e consultores do empreendimento 3 (em ordem alfabética de assunto)

\begin{tabular}{ll}
\hline Acústica & $\begin{array}{l}\text { Consultor de estacionamento (fluxo veículos e } \\
\text { pontos de controle) }\end{array}$ \\
\hline Ar condicionado e sist. mecânicos & Estrutura de concreto \\
\hline Arquitetura & Estrutura metálica \\
\hline Automação & Fundações \\
\hline Caixilharia & Impermeabilização \\
\hline Consultor de certificação ambiental & Luminotécnica \\
\hline Consultor de pedras para fachada & Segurança patrimonial \\
\hline Consultor de acessibilidade & Sistemas prediais (elétrica e hidráulica) \\
\hline
\end{tabular}




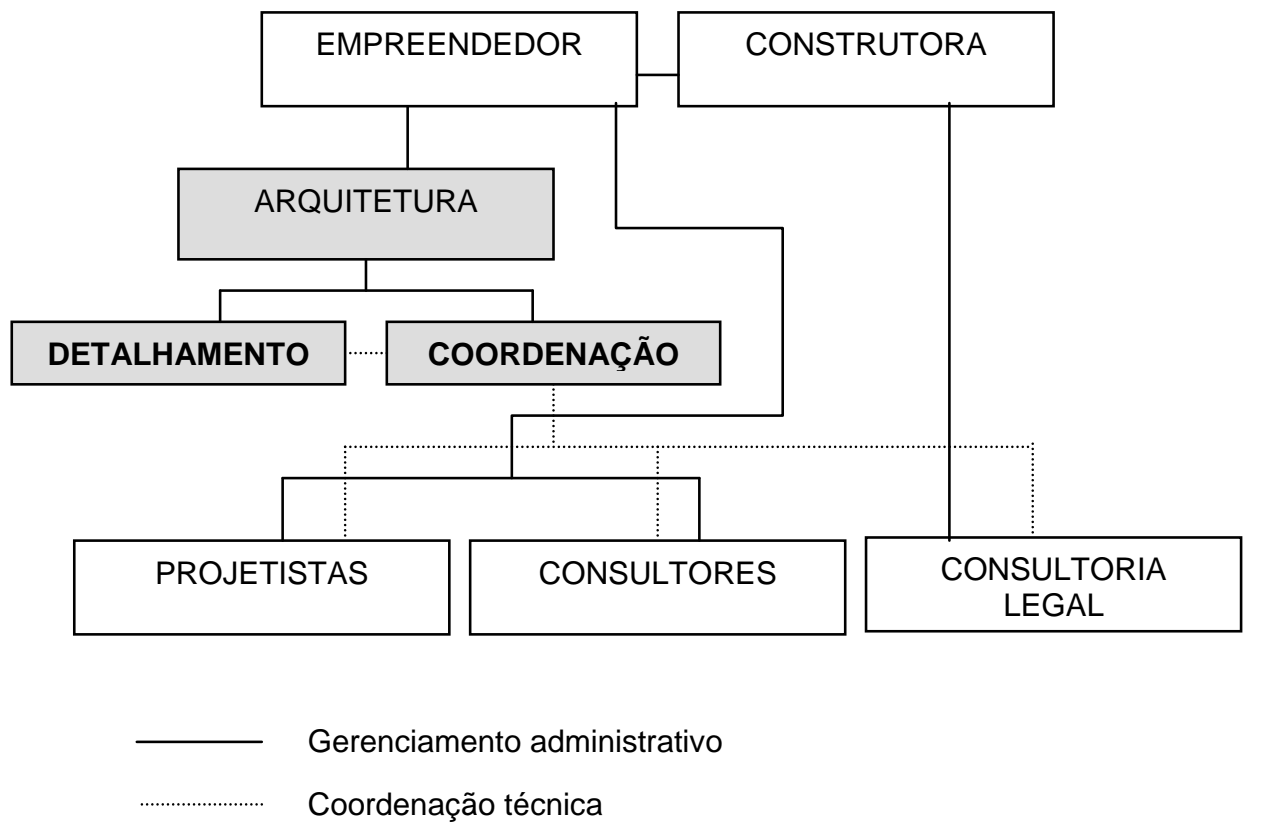

Figura 87 - Arranjo entre os principais agentes do processo de projeto do empreendimento 3

Uma das dificuldades enfrentadas no processo de projeto deste empreendimento estava relacionada com a dinâmica das interfaces entre a incorporadora e o escritório de arquitetura (autor do projeto), que se subdividiu em três diferentes interlocutores (pelo menos um representante de cada empresa) para responderem às questões da arquitetura e da coordenação. Além disso, houve um problema de conflito gerencial por parte do escritório de arquitetura e da coordenação, sendo que este último também desconhecia os fluxos internos da incorporadora. Esta dinâmica refletiu-se no descumprimento dos prazos do planejamento original e na finalização da etapa do Projeto Básico com três meses de atraso. Outro fato que comprometeu o andamento do processo do projeto foi o retorno tardio e negativo da aprovação legal no município. Na época da finalização da etapa do Anteprojeto, optou-se por continuar o desenvolvimento do processo, mesmo sem o pronunciamento oficial da municipalidade, por dois motivos principais: primeiro, para ganhar tempo, pois a demora no retorno dos órgãos públicos locais era usual e de conhecimento de todos; segundo, era uma decisão aparentemente de baixo risco, pois o fato de haver um consultor legal envolvido gerou o entendimento de que os principais aspectos restritivos estavam contemplados. Quando aconteceu o retorno do processo de aprovação, evidenciou-se que o entendimento estava equivocado e a etapa do Projeto Básico já estava finalizada. Como a restrição alertada pelo processo de aprovação inviabilizava o projeto da forma como estava, ele teve que retornar ao início do processo, na fase do Projeto Preliminar. 


\subsubsection{Certificação ambiental}

Apesar do processo de projeto ter retornado ao início, faz parte da concepção deste empreendimento a obtenção da certificação ambiental, de maneira que o consultor específico para esta disciplina foi mantido para a reformulação do projeto. 


\section{ANÁLISE CRÍTICA}

\subsection{ANÁLISE DO PROCESSO}

\subsubsection{Quanto à gestão do processo}

A política interna da incorporadora de manter uma equipe reduzida para a equipe técnica de projetos e de contratar externamente o coordenador de projetos, como observado nos estudos de caso, fez que a gestão do processo de cada projeto fosse sempre dividida em duas partes: a parte tática e a parte operacional. A primeira, representada pela equipe interna da incorporadora, detinha todo o conhecimento técnico e dos fluxos dos processos internos; estava familiarizada com as implicações de custos e de prazos de cada empreendimento e era a responsável pela contratação dos projetistas e consultores da cada processo de projeto. A segunda parte, representada pelo coordenador de projetos externo, era responsável por toda a parte operacional do processo: convocar os agentes para as reuniões, coordenar as reuniões, redigir as atas, elaborar o cronograma de projeto, fazer o acompanhamento dos contratos com os projetistas, cobrar o atendimento dos prazos, redigir relatórios e dirimir dúvidas técnicas que estivessem ao seu alcance.

Por este motivo, o processo de projeto desenvolveu-se em melhores condições quando houve uma boa interação entre o coordenador externo e a equipe interna da incorporadora, fato que ocorreu no empreendimento 1, quando o escritório de arquitetura tinha prévio conhecimento dos processos internos da incorporadora. O empreendimento 2, com o arranjo experimental entre arquitetura e coordenação, foi considerado um processo com muitos problemas ${ }^{75}$, tanto é que a incorporadora descartou a hipótese de repetir este tipo de arranjo em projetos em um futuro próximo. O empreendimento 3 , emblemático, denotou a inexistência de interação entre arquitetura, coordenação e incorporadora, o que, junto com o problema da aprovação legal, comprometeu o processo de projeto de tal forma que a concepção inicial precisou ser refeita. Este último caso mostrou que mesmo empresas com processos estruturados e formalizados podem sofrer com desarranjos e problemas de difícil solução em seus projetos quando aspectos relativos a liderança não estão claros para todos.

\footnotetext{
${ }^{75}$ Apesar da incorporadora ter concluído que o modelo era ineficaz, não ficou claro se o problema poderia estar relacionado à seleção do coordenador externo.
} 
Em relação à fase de operação e manutenção, evidencia-se que as informações de usuários das quais a incorporadora dispõe são relativas às áreas comuns do empreendimento. Estas informações, aliadas ao acompanhamento da operação dos sistemas prediais do empreendimento, são a fonte para a retroalimentação do processo do projeto.

\subsubsection{Quanto às etapas do processo}

As fases observadas do fluxo do processo, no estudo de caso, permitem fazer um paralelo (Figura 88) com as fases comentadas na revisão bibliográfica, incluindo o modelo proposto por Romano (2003) ilustrado pela Figura 54. Ambos os modelos têm suas macrofases bem definidas e consideram uma fase inicial de Concepção, na qual o programa de necessidades é definido. Suas fases subseqüentes são muito semelhantes, incluindo a nomenclatura.

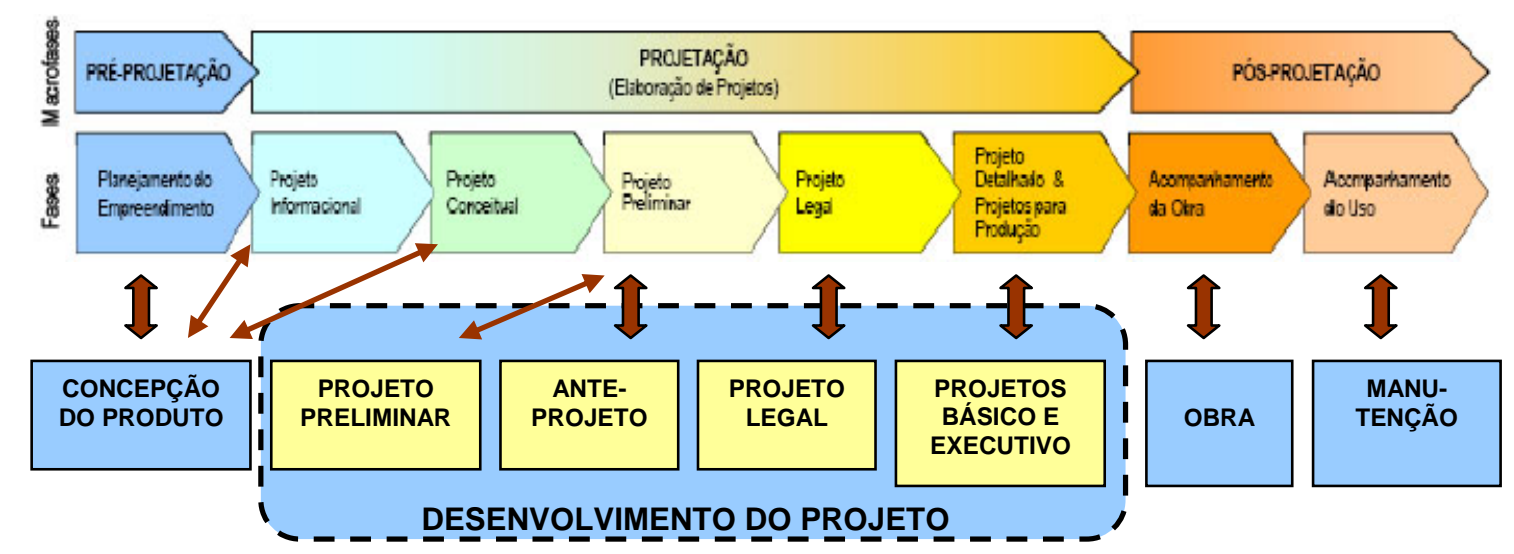

Figura 88 - Paralelos entre fluxos de processos de projetos

Também foi observado que os fluxos de desenvolvimento do negócio e dos projetos apresentam, em cada fase, etapa e sub-etapa, uma preocupação constante com a aferição dos valores relacionados à sua execução, valores que devem estar sempre de acordo com os números gerados nos primeiros estudos analíticos. Como o parâmetro de valor de construção baliza o estudo de viabilidade econômica do negócio, o conceitual técnico deve estar decidido já na fase de definição do produto, antes mesmo do arquiteto fazer o primeiro esboço do pavimento tipo.

Além disso, uma validação de projetos se fez necessária para que as características técnicas definidas no Projeto Preliminar se mantivessem durante o desenvolvimento de todo o processo até a sua finalização, pois o balizamento do projeto, caso fosse somente 
orientado pelos valores, poderia incorrer em tentativas de modificar estas características, com implicações eventuais no desempenho do futuro edifício. Esta validação foi feita, nos diversos empreendimentos, por meio de reuniões de coordenação específicas para este fim, geralmente ao término de cada fase de projeto.

$E$, apesar das fases do processo serem essencialmente sequenciais, como ilustrado nos fluxos das Figuras 71 e 72, pôde-se perceber que a empresa praticou intuitivamente alguns conceitos baseados no enfoque do projeto simultâneo, ao prever em seu processo a participação de todos os agentes do projeto nas reuniões de coordenação, principalmente representantes da construtora e do Departamento de Administração Predial nas reuniões de validação, mesmo que para isso a quantidade de participantes ficasse aparentemente excessiva. 


\subsection{ANÁLISE DAS FERRAMENTAS}

A principal ferramenta para o planejamento do processo de projeto utilizada pela incorporadora, o Manual de Coordenação de projetos, é bem estruturada e cobre as principais questões que devem ser desenvolvidas pelo coordenador de projetos. $\mathrm{O}$ fato de a gestão do processo estar dividida entre a incorporadora e o coordenador faz que o uso eficaz desta ferramenta esteja diretamente relacionado à interação deste coordenador com os processos internos da incorporadora. O perfil pessoal deste coordenador, que inclui a experiência técnica e a habilidade de liderar equipes, também influi fortemente no resultado do processo de projeto, uma vez que a expectativa da incorporadora é de que o coordenador de projeto lidere de fato todo o processo, minimizando a esfera administrativa que a incorporadora tem sobre a gestão.

Neste sentido, seria conveniente que, neste Manual, houvesse a descrição dos fluxos internos da incorporadora, relacionados ao desenvolvimento dos projetos, para que o coordenador pudesse prever, no desenvolvimento do cronograma, os prazos necessários para as avaliações de custo e de aprovações por parte da matriz americana, fatos que acontecem no processo e normalmente não são considerados no planejamento.

As demais ferramentas (formulários, relatórios, etc) utilizadas pelo Departamento de P\&C denotam uma preocupação em formalizar as atividades do processo, o que é bastante útil na necessidade de um eventual rastreamento destas atividades.

Quanto à tecnologia da informação, observa-se que a utilização de softwares comercialmente disponíveis no mercado para a elaboração de documentos e análises de projetos, além de ferramenta de extranet para armazenagem, distribuição e controle destes documentos, é feita de maneira tradicional, ou seja, cada tipologia de documento é gerada por um software específico e o projeto de cada disciplina é gerado a partir de uma base comum, mas estanque em cada projetista ou consultor envolvido. Os softwares são utilizados como editores, pranchetas, armazenadores e correspondências eletrônicas, mas a gestão do processo como um todo ainda é manual. Encontros internos entre a matriz norteamericana e suas afiliadas de outros países demonstram que a incorporadora tem conhecimento de ferramentas modeladoras e integradoras como o $B I M^{76}$, e é de se imaginar que uma empresa que trabalha verticalmente com o negócio imobiliário tenha interesse em

${ }^{76}$ Ver seção 3.1 do capítulo C. 
ferramentas que possibilitam a modelagem $4 D^{77}(3 D+$ tempo) ou até $5 D(3 D+$ tempo + custos), mas não foram observados o uso ou a intenção de uso, em um futuro próximo, deste tipo de ferramenta nos empreendimentos brasileiros.

${ }^{77} \mathrm{D}$ de dimensão, ou seja, modelagem 3D = modelagem tridimensional. 


\subsection{ANÁLISE DO PRODUTO}

\subsubsection{Arquitetura}

As torres dos edifícios de escritórios dos casos estudados, mesmo em etapas diferentes do processo de projeto, apresentam muitos pontos em comum, decorrência direta do tipo e padrão do produto imobiliário que a incorporadora deseja comercializar: são edifícios com alta classificação mercadológica, normalmente localizados em regiões nobres das cidades onde estão implantados e fazem parte de grandes empreendimentos (mais de $170.000 \mathrm{~m}^{2}$ ).

Os pavimentos-tipo destes edifícios têm lajes grandes (de $1.800 \mathrm{~m}^{2}$ a $2.400 \mathrm{~m}^{2}$ ) e mesma solução de planta livre e núcleo central, com profundidades medianas (variando entre 11,80m e 17,70m) e pé-direito mínimo de 2,70m. A preferência por este tipo de conformação decorre de experiências bem-sucedidas da matriz norte-americana, em projetos anteriores, que denotam a profundidade mediana como a ideal para garantir flexibilidade de ocupação, densidades compatíveis com bons níveis de produtividade e, ao mesmo tempo, conforto com o contato visual da luz natural e da paisagem externa. O pé-direito de $2,70 \mathrm{~m}$, maior do que normalmente exigido por legislação, é um dos critérios para a classificação mercadológica alta.

Todos os pavimentos-tipo apresentam a configuração de piso elevado e forro acústico modular, e as alturas de piso a piso variam de acordo com a solução estrutural (entre 3,84m a 4,10m), pois a solução de distribuição do ar condicionado, pelo forro, também é comum nos três casos.

A relação entre a área para comercialização (área BOMA) e a área construída nos pavimento-tipo, indicativo de eficiência nas áreas, também é alta (no empreendimento 1, 87,5\%; no empreendimento 2, 94\%; e no empreendimento 3, 92,5\%). Diz-se que o empreendedor "adquire" a edificação pela área construída e a "comercializa" pela área $B O M A$, razão pela qual a relação entre estas, dentro de certos parâmetros, deve ser a mais alta possível. Por outro lado, uma razão excessivamente alta (muito próxima de $100 \%$ em edifícios multi-pavimentos) denota alguma deficiência no sistema predial ou no sistema de segurança da edificação, uma vez que as escadas, elevadores e shafts não são contabilizados na área BOMA. Esta procura por áreas comercialmente eficientes também tem influência na definição do tamanho das lajes dos pavimentos e na centralidade do núcleo. Além disso, todos os casos estudados apresentam a peculiaridade de terem 
localizadas, no núcleo, as instalações sanitárias, que, apesar de serem contabilizadas no cálculo do aluguel, não são áreas privativas, estando sua limpeza e manutenção sob responsabilidade da administração predial, e não do inquilino.

No que diz respeito às modulações horizontais, percebe-se a preferência pela modulação estrutural que "casa" com a modulação construtiva (múltiplos de 1,25cm), o que ocorre com os empreendimentos 1 e 2. Entende-se que a modulação adotada no empreendimento 3 seja decorrente dos seguintes aspectos: um possível melhor aproveitamento da área em relação ao terreno; formulação do projeto conceitual feito por um escritório estrangeiro; e negociação entre a solução estrutural (presença de pilares na área privativa) e a relação de eficiência de áreas construída x área BOMA. O descompasso entre a modulação estrutural e a construtiva, neste caso, faz que seja necessário o recurso do forro de gesso na periferia do pavimento, para possibilitar o arremate do forro modular desencontrado com a modulação de fachada.

As fachadas, por sua vez, são concebidas com a finalidade maior de refletir a imagem corporativa e o padrão mercadológico que a incorporadora deseja transmitir em seus produtos imobiliários. Isto é tão importante que estes elementos, durante o processo de projeto, devem ter aprovação da matriz norte-americana, e os critérios mais importantes que devem ser atendidos, nesta aprovação, são subjetivos. Isto explica, em parte, a adoção de fachadas-cortina e semi-cortina com altas taxas de áreas envidraçadas, principalmente no empreendimento 1, cujas condições climáticas são desfavoráveis a este tipo de solução.

\subsubsection{Estrutura}

Os três casos apresentam estruturas reticuladas de concreto armado, com solução de lajes, pilares, vigas e paredes de contraventamento (no núcleo), cada caso com características específicas quanto ao tipo de laje e a combinação desta com vigas e elementos de protensão. A preferência da incorporadora pela solução em concreto na construção das edificações brasileiras denota que a relação custo-benefício deste sistema estrutural, para o tipo de produto imobiliário que ela desenvolve, ainda é melhor do que a solução metálica, amplamente utilizada nos projetos da matriz norte-americana.

A estrutura com maior altura é a do empreendimento 2, que conta com a utilização de laje com vigas e aberturas nestas para grandes passagens de instalações, e a menor altura é a do empreendimento 1 , em que as instalações passam pelo espaço entre a laje e o forro. 
Uma estrutura mais alta é, via de regra, mais econômica do que uma mais baixa, com mesma solicitação de cargas e vãos. O contraponto desta possível vantagem diz respeito à área vertical maior de fachada que esta estrutura incorpora. Como as diferenças de alturas de piso a piso têm efeito cumulativo, o balanço mais favorável de cada solução depende das características do conjunto da edificação. Não à toa, o empreendimento 2, que tem a maior altura estrutural, é o que tem menos pavimentos (14); e o empreendimento 1, com a menor altura estrutural, é o que tem mais pavimentos (33).

\subsubsection{Sistemas prediais}

Os sistemas de ar condicionado dos três casos apresentam o sistema de expansão indireta, utilizando água como meio refrigerante. Este sistema tem a preferência da incorporadora devido à sua relação de custo-benefício para a tipologia de seus empreendimentos e gastos operacionais considerados por ela satisfatórios. Somente o empreendimento 2 não utiliza uma central de água gelada, partindo para a solução a ar, com o equipamento tipo selfcontained. Este caso pode ser entendido como o meio-termo entre os interesses de alguns sócios do empreendimento, que preferem implantar o mínimo de sistemas prediais, e a incorporadora, que tem o interesse no custo da operação da edificação. A implantação do equipamento tipo self pode ficar a cargo do futuro usuário, e a necessidade da torre de resfriamento decorre da localização central do equipamento tipo self, que não tem como jogar o calor - oriundo de seu processo - direto no ambiente externo.

A distribuição do ar condicionado, pelo forro nos três casos, decorre de pesquisas informais por parte dos representantes técnicos e da administração predial da incorporadora, que indicam casos de situações de desconforto (sensação de "frio nos pés") no sistema de distribuição pelo piso.

O sistema de reservação de água potável e de combate a incêndios utiliza, em dois empreendimentos, sistema de pressurização para distribuição, pois não contam com reservatórios superiores. Este sistema de pressurização tem um esquema de alimentação elétrica especial, para garantir o abastecimento de água na falta de energia da concessionária.

Todos os empreendimentos têm previsão para o tratamento de água oriunda da drenagem do sistema de ar condicionado e de chuvas. Os empreendimentos 2 e 3 também contam com o reuso das águas cinzas. A reservação da água tratada para reuso é armazenada nos 
pavimentos inferiores e distribuída por sistema de pressurização. Esta preocupação em utilizar água de fontes alternativas, que tenta compensar o alto consumo de água do sistema das torres de resfriamento, serve como apelo mercadológico e conta pontos em programas de certificação ambiental.

Observa-se também que a incorporadora tenta evitar a utilização de reservatórios superiores, tanto de água potável, quanto de reuso, em seus empreendimentos, e infere-se que isto tem influência de seus empreendimentos norte-americanos, que só preveem esta solução para edifícios muito altos.

Na questão do transporte vertical, percebe-se a divisão dos grupos de elevadores em zonas alta e baixa, para todos os casos, independente da altura dos empreendimentos. Como o tempo de espera dos elevadores também conta pontos na classificação mercadológica do empreendimento, esta solução é possivelmente a que traz a quantidade mais otimizada de carros para o grau de serviço que se deseja obter. 


\subsection{CONSIDERAÇÕES SOBRE O ESTUDO DE CASO}

O fluxo do processo de projeto do estudo de caso e dos empreendimentos acompanhados, mesmo nas fases iniciais, caracteriza-se pela constante aferição, em cada fase e etapa, de sua coerência com os valores do resultado do final do processo de Concepção do Produto. Além disso, observa-se que uma parte das diretrizes técnicas aparece de forma indireta no Programa de Necessidades da fase de Concepção de Produto (ex: espaçamentos, número de andares e sistemas de ar condicionado, que influenciam na conceituação estrutural) e a outra parte é definida na fase subsequente, o Desenvolvimento do Projeto (solução estrutural definitiva, conceituação das instalações prediais, aspectos relacionados à eficiência energética do edifício e de seu funcionamento).

Isto permite algumas reflexões: a) a empresa do estudo de caso apresenta um processo de projeto organizado e estruturado, o que é pouco usual se comparado à realidade do mercado brasileiro; b) as aferições periódicas previstas no processo são instrumentos de controle importantes do próprio processo que permitem o questionamento e a avaliação da qualidade técnica das soluções propostas e c) é no processo de Concepção do Produto em que as principais diretrizes técnicas de um projeto devem já estar definidas, incluindo as que relacionam os aspectos de operação e manutenção do edifício, pois a viabilidade econômica definida nesta fase determina todo o restante do processo.

Considerando a importância do resultado da Concepção do Produto, observa-se, contudo, que as diretrizes para o Plano de Massas não inclui os estudos para fachada, que aparecem somente na etapa posterior, a do Projeto Preliminar (dentro da fase de Desenvolvimento de Projeto). Especula-se que isto seja decorrente da larga aplicação do mesmo tipo de solução construtiva para as fachadas (fachada-cortina ou semi-cortina ${ }^{78}$ ) para os projetos de edifícios de escritórios, o que aparentemente não gera grandes impactos diferenciais em estudos analíticos de valores.

Mesmo com esta ressalva, a estruturação do processo do estudo de caso pode ser tomada como base para a proposição de processos de projeto para empreendimentos similares, mesmo que estes não sejam necessariamente concebidos como produtos imobiliários (ex: projeto de construção ou readequação da sede própria de corporações), incluindo na fase de Concepção de Produto os estudos iniciais de fachadas. Acredita-se que outras soluções

${ }^{78}$ Ver seção 1.3.1 do Capítulo B. 
construtivas para elas poderão ser exploradas, considerando-se o crescente reconhecimento de sua importância no consumo de recursos do edifício ao longo do tempo.

Sabe-se que quanto mais precisas forem as definições feitas na fase de Concepção do Produto, menores serão as distorções que poderão ocorrer nas fases posteriores do processo de projeto. Contudo, não se espera que todas as definições sejam feitas de modo preciso nesta fase inicial, por vários motivos: não há uma verdade única e final para este tipo de empreendimento, há um espaço de tempo considerável entre a concepção e a efetiva operação do mesmo, e há a necessidade natural de maturação do projeto do empreendimento considerando o local em que ele será inserido e a realidade de ocupação do mercado. Às vezes, readequações ao longo do processo podem ser inevitáveis.

Desta forma, é possível pensar em definições minimamente necessárias para a fase inicial do processo de projeto e as reflexões sobre o estudo de caso sugerem que as diretrizes técnicas de um projeto de edifício de escritórios podem ser divididas em duas categorias principais: diretrizes para o Plano de Massas e diretrizes para o desenvolvimento restante do projeto. A primeira categoria definiria o contorno do edifício, suas principais áreas, o número de pavimentos, a expectativa de durabilidade do mesmo (ciclo de vida) e a flexibilidade de uso. A segunda categoria definiria principalmente como o edifício iria funcionar, quando em operação, e que contingências ele deveria cobrir (ex: funcionamento do edifício na falta de água, energia, em situação de emergência). Pela importância já discorrida do resultado do processo de Concepção do Produto, optou-se por priorizar a identificação das principais diretrizes que devem ser contempladas para a elaboração do Plano de Massas. 


\subsection{DIRETRIZES PARA O PLANO DE MASSAS}

Recordando o fluxo do processo da fase de Concepção do Produto do estudo de caso, temos as seguintes etapas:

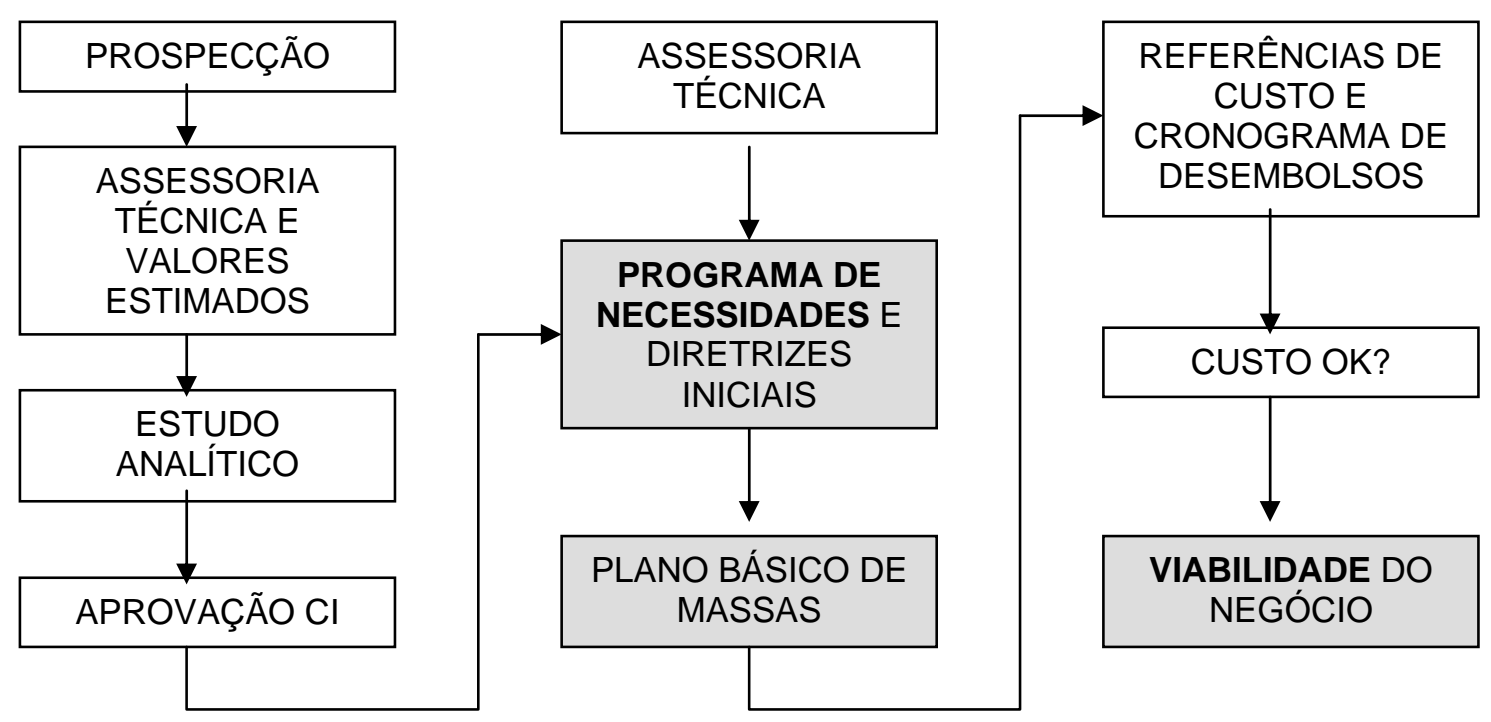

Figura 89 - Fluxo do processo de Concepção do Produto do estudo de caso

Fonte: incorporadora em estudo

Como já comentado anteriormente, as diretrizes para o Plano de Massas assumem importância crucial no processo do projeto por definirem os custos e a referência do edifício de escritórios como produto imobiliário, aspectos estes que serão sempre referenciados a cada fase e etapa posterior. A identificação de algumas destas diretrizes, possibilitada pela revisão bibliográfica e pelo estudo de caso, permite a proposição de um detalhamento da interação deste do Programa de Necessidades com o Plano Básico de Massas (Figuras 89 e 90), conforme descrição abaixo:

1 - Uma vez definido o terreno e o produto comercial ${ }^{79}$ (padrão do escritório, empreendimento para venda ou aluguel, expectativa de durabilidade do edifício, nível de flexibilidade), faz-se o levantamento dos critérios legais ${ }^{80}$ do terreno. Estes determinarão, por meio de coeficientes, afastamentos e gabaritos de altura, os contornos possíveis do edifício, as áreas máximas de construção e eventuais restrições de ocupação;

\footnotetext{
${ }^{79}$ Ver seção 1.2.1 do Capítulo C.

${ }^{80}$ Ver seção 1.2.1 do Capítulo B.
} 
2 - Destas áreas máximas, estima-se a área BOMA $^{81}$ desejável. Esta área serve como referencial para a rentabilidade do empreendimento e como base para estimar a área do pavimento tipo e as outras áreas do edifício, além da existência ou não de subsolos;

3 - Parte-se, então, para as seguintes definições conceituais: formato do pavimento, tipologia de núcleo ${ }^{82}$, profundidade média do andar $^{83}$, sistema estrutural ${ }^{84}$, sistema de distribuição de ar condicionado ${ }^{85}$, existência ou não de piso elevado. Estes conceitos, em conjunto, determinam a altura de piso a piso dos andares ${ }^{86}$, que, junto com as áreas máximas de construções, definem o número de pavimentos do edifício;

4 - Conceitua-se também parte da operação do edifício, que, junto com a área do pavimento tipo e o números de pavimentos, definirá um número estimado de elevadores ${ }^{87}$ e sua solução de distribuição (com ou sem zoneamento, elevadores exclusivos para subsolos com parada obrigatória na recepção para identificação, elevadores de emergência);

5 - Define-se, então, o pavimento tipo, considerando as principais modulações horizontais ${ }^{88}$, a área efetiva para uso de escritórios, os espaços para instalações prediais ${ }^{89}$ (principalmente ar condicionado) e as circulações verticais, tais como rotas de fuga, escadas, elevadores;

6 - Conceitua-se a fachada ${ }^{90}$ (que tem estreita relação com a solução conceitual do ar condicionado) e o padrão de acabamento de materiais (que influenciam na manutenibilidade da edificação);

7 - Verifica-se, com o pavimento tipo conceituado, se os assuntos anteriores necessitam passar por revisão ou adequação (ex: se os índices de área indicam rentabilidade desejada, se as áreas técnicas estão subdimensionadas ou excessivas, se há muitos elevadores, se o núcleo está desproporcional em relação ao pavimento);

8 - Conclui-se o plano de massas.

A numeração destas diretrizes, bem como o fluxo proposto (Figura 90), é apenas indicativa e não estabelece necessariamente a ordem em que estas devem ser atendidas. Apenas indicam que elas devem estar contempladas na elaboração do Plano de Massas.

\footnotetext{
${ }^{81}$ Ver seção 1.2.1.2 do Capítulo B.

${ }^{82}$ Ver seção 1.2.2.1 do Capítulo B.

${ }^{83}$ Ver seção 1.2.2.2 do Capítulo B.

${ }^{84}$ Ver seção 2.2.3 do Capítulo B.

${ }^{85}$ Ver seção 3.2.5 do Capítulo B.

${ }^{86}$ Ver seção 1.2.2.3 do Capítulo B.

${ }^{87}$ Ver seção 3.7 do Capítulo B.

${ }^{88}$ Ver seção 1.2.2.2 do capítulo B.

${ }^{89}$ Ver seção 3 do capítulo B de Sistemas Prediais como um todo, mas pode-se utilizar referência das tabelas de áreas dos empreendimentos do estudo de caso na seção 4 do capítulo D.

${ }^{90}$ Ver seção 1.3 do Capítulo B.
} 


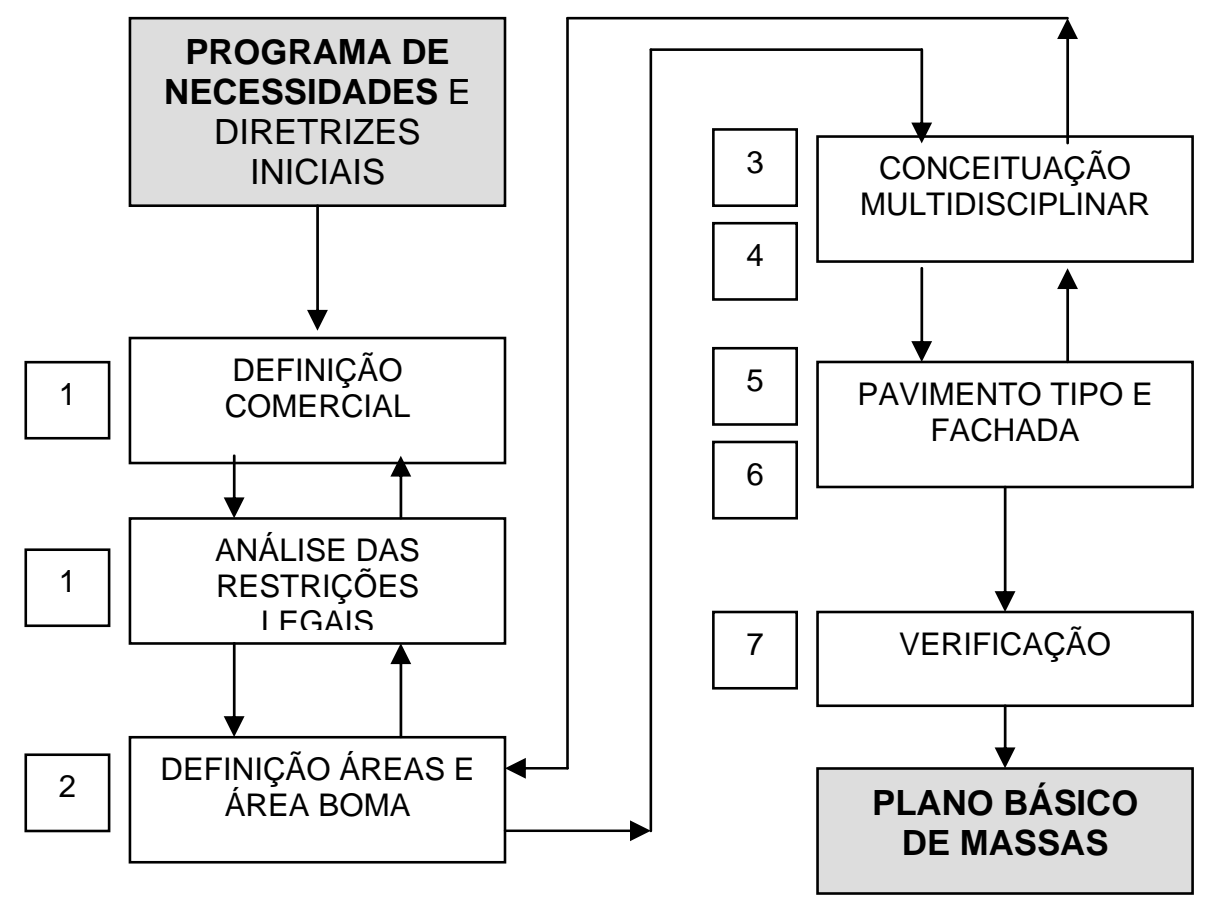

Figura 90 - Diretrizes do detalhamento da fase entre o Programa de Necessidades e o Plano de Massas

Deste fluxo, pode-se inferir que, ainda numa fase essencialmente comercial e de montagem de um empreendimento composto por edifício de escritórios, há a clara necessidade de se dominar conceitos técnicos, além da própria arquitetura em si, de disciplinas tais como: estrutura, ar condicionado, segurança pessoal, administração predial e sistemas de transporte vertical (elevadores). As definições das disciplinas também trazem consigo a facilidade ou não do atendimento aos aspectos construtivos do empreendimento, que podem ser ressaltados pela definição das modulações horizontais, e aos aspectos de operação e manutenção, dependendo dos espaços para instalações definidos para as alturas de piso a piso e dos tipos de acabamentos.

Para o caso de um agente incorporador ou empreendedor hipotético que esteja buscando melhoria em seus processos, pode-se também sugerir o modelo do processo de projeto de Romano $^{91}$ (2003), com a incorporação deste fluxo na fase de Pré-Projetação.

Espera-se que, em projetos de empreendimentos de edifícios de escritórios, a adoção de um fluxo de Concepção de Produto similar ao do estudo de caso, acrescido deste detalhamento inicial, facilite a continuidade e evite futuros desvios significativos do processo do projeto como um todo.

\footnotetext{
${ }^{91}$ Ver seção 1.3 do Capítulo C.
} 


\section{CAPÍTULO E - CONSIDERAÇÕES FINAIS}

\section{CONSIDERAÇÕES SOBRE OS RESULTADOS DA PESQUISA}

Uma das principais constatações desta pesquisa refere-se à pouca disponibilidade de referências bibliográficas nacionais que tratam especificamente de aspectos técnicos de projetos de edifícios de escritórios e quase nenhuma que combine estes com os de gestão do processo de projeto. Os aspectos técnicos estão, em sua maior parte, espalhados em publicações específicas, seja em forma de livros e revistas orientados por disciplina de projeto, seja em forma de normas e leis organizadas por esfera de atuação (municipal, estadual ou federal) e não estão direcionados para este tipo específico de edificação. E, diferentemente do esperado, as referências internacionais, mesmo com dados mais abrangentes e linhas de pesquisa atuando há mais tempo sobre o assunto edifícios de escritórios, encontram dificuldades para sua aplicação direta na realidade local em decorrência de diferenças culturais de seus modelos, e este aspecto torna-se mais enfático quando o assunto de gestão é considerado.

Assim, a seleção criteriosa destas informações e a forma na qual o trabalho está organizado, principalmente o conteúdo dos capítulos B e C, podem ser consideradas, por si só, como diretrizes de projetos de edifícios de escritório, ao tratar dos assuntos técnicos e de gestão dentro dos parâmetros de conhecimento e de funcionamento do mercado local de empreendimentos imobiliários. Estas diretrizes são ainda mais evidenciadas no processo e nos empreendimentos do estudo de caso, o que mostra a aplicabilidade desta pesquisa e sua utilidade como ferramenta de gestão. 


\subsection{ATENDIMENTO AOS OBJETIVOS DA PESQUISA}

O objetivo principal da pesquisa foi propor diretrizes para o desenvolvimento de projetos de edifícios de escritórios, considerando os aspectos técnicos multidisciplinares do projeto, os aspectos de gestão de seu processo e os aspectos relacionados ao uso e manutenção do edifício. Entende-se que o objetivo foi atendido, uma vez que:

- Os aspectos técnicos multidisciplinares foram explicitados na revisão bibliográfica, que contou ainda com a opinião de diversos profissionais de projeto e consultores especializados, e indicou a influência que cada disciplina exerce sobre a conceituação do projeto e as diversas possibilidades de resultados que elas podem trazer com suas interações. Isto traz à tona a necessidade do entendimento conceitual destes aspectos pelos profissionais que estão envolvidos diretamente com o início da concepção de um projeto;

- Os aspectos relacionados ao uso e manutenção do edifício, apresentados na revisão bibliográfica e no estudo de caso, remetem à importância de um processo de projeto com planejamento adequado e que tenha dados de retroalimentação desta fase posterior. Projetos que têm aspectos construtivos e de manutenção planejados têm o benefícios de redução de riscos de despesas futuras imprevistas, e isto é um dos itens observados no processo de projeto do estudo de caso, a constante aferição dos valores do empreendimento a cada etapa avançada do processo;

- O fluxo sugerido para o processo do projeto como um todo é coerente com os modelos observados, tanto na revisão bibliográfica, quanto no estudo de caso (indicando que é aplicável), e o detalhamento proposto da fase de concepção de projeto permite esclarecer quais os principais itens das diversas disciplinas que devem ser abordados e o motivo pelo qual são relevantes nesta fase do processo;

- Além disso, ao explorar a vertente do estudo sobre as relações organizacionais envolvidas na gestão do processo de projeto, o estudo de caso ressaltou alguns itens da revisão bibliográfica relacionados à importância da figura do coordenador de projetos e à interação entre os principais agentes do processo de projeto, ao apresentar diferentes arranjos para esta interação e as condições de desenvolvimento conseqüentes nos empreendimentos. 


\subsection{SUGESTÃO PARA TRABALHOS FUTUROS}

O tema projeto para edifícios de escritórios, como já abordado no início do capítulo $A$, permite vários enfoques e, consequentemente, várias linhas de estudos futuros. Dentro do enfoque adotado para este trabalho, que trata de aspectos técnicos e de gestão de processo de projeto, algumas lacunas puderam ser identificadas como oportunidades para pesquisas complementares:

- A elaboração das diretrizes de projetos de edifícios de escritório para a fase após o Plano de Massas, ou seja, as diretrizes que detalham o funcionamento da edificação e que estão relacionadas aos Sistemas Prediais e a serviços de operação e manutenção;

- O planejamento do processo de projeto de edifícios de escritórios como produto imobiliário, por meio de modelagem específica, tomando por base: o fluxo do processo proposto neste trabalho, as diretrizes do Plano de Massas, as diretrizes das fases posteriores do processo e os prazos hipotéticos (considerando as práticas de mercado). Esta modelagem poderia ser feita por meio da metodologia $A d e P T^{92}$, para que as interações entre disciplinas e atividades simultâneas pudessem ser visualizadas e as possibilidades máximas de redução de cronograma para um projeto desta natureza ficassem evidentes;

- A análise, no processo de projeto, da influência da etapa de construção sobre a operação e manutenção de edifícios de escritórios, além de seus principais dados de retroalimentação para o projeto;

- O estudo do impacto de ferramentas BIM sobre a gestão do processo de projeto de edifícios de escritórios e sua adequação às necessidades brasileiras.

Além dos temas diretamente relacionados com esta pesquisa, pode-se sugerir:

- A elaboração de diretrizes de projetos para edifícios com outros usos, tais como hospitais e escolas, nos mesmos moldes dos edifícios de escritórios.

${ }^{92}$ Ver seção 1.2.2 do capítulo C. 


\section{REFERÊNCIAS BIBLIOGRÁFICAS}

ARGE, K. Adaptable office buildings: theory and practice. Facilities, vol. 23, number 3/4, 2005. p. 119-127.

ALBUQUERQUE, A. T. Análise de alternativas estruturais para edifícios em concreto armado. 1999. 100 p. Dissertação (Mestrado). Escola de Engenharia de São Carlos, Universidade de São Paulo, São Carlos: 1999.

AMARAL, C. S. Escritório: o espaço da produção administrativa em São Paulo. Dissertação (Mestrado). 1995. Faculdade de Arquitetura e Urbanismo, Universidade de São Paulo. São Paulo, 2005.

AMERICAN NATIONAL STANDARD. ANSI / BOMA Z65.1-1996: Standard method for measuring floor area in office buildings. Washington D.C.: Building Owners and Managers Association International, 1996. 36 p.

AMERICAN SOCIETY OF CIVIL ENGINEERS. ASCE 7-05: Minimum design loads for buildings and other structures. USA, 2006. 424 p.

AMERICAN SOCIETY of HEATING, REFRIGERATING, and AIR-CONDITIONING ENGINEERS. 2005 ASHRAE Handbook - Fundamentals. ASHRAE, 2005. 1 CDROM.

ANDRADE, C. M. A. de. Avaliação de desempenho em edifícios de escritórios: 0 ambiente de trabalho como o meio para o bem estar produtivo. Tese (Doutorado). 2005. Faculdade de Arquitetura e Urbanismo, Universidade de São Paulo. São Paulo: 2005.

ANDRADE, C. M. A. de. A história do ambiente de trabalho em edifícios de escritórios - Um século de transformações. São Paulo: C4, 2007. 96 p.

ASSOCIAÇÃO BRASILEIRA DE NORMAS TÉCNICAS. NBR 5410: Instalações elétricas de baixa tensão. Rio de Janeiro, 2004. 209 p.

NBR 5413: Iluminância de interiores. Rio de Janeiro, 1992. 13 p.

. NBR 5626: Instalação predial de água fria. Rio de Janeiro, 1998. 41 p. 
. NBR 5665: Cálculo de tráfego nos elevadores - Procedimento. Rio de Janeiro, 1983. 12 p.

NBR 6118: Projeto de estruturas de concreto - Procedimento. Rio de Janeiro, 2007. $221 \mathrm{p}$.

NBR 6120: Cargas para o cálculo de estrutura de edificações. Rio de Janeiro, 1980. 5 p.

. NBR 6123: Forças devidas ao vento em edificações. Rio de Janeiro, 1988.

$66 \mathrm{p}$.

NBR 7198: Projeto e execução de instalações prediais de água quente. Rio de Janeiro, 1993. $6 \mathrm{p}$.

. NBR 8160: Sistemas prediais de esgoto sanitário - Projeto e execução. Rio de Janeiro, 1999. $74 \mathrm{p}$.

. NBR 9050: Acessibilidade a edificações, mobiliário, espaços e equipamentos urbanos. Rio de Janeiro, 2004. 97 p.

. NBR 9077: Saídas de emergência em edifícios. Rio de Janeiro, 2001. 40 p.

. NBR 10821: Caixilhos para edificações - Janelas. Rio de Janeiro, 2000. 37

p.

. NBR 10844: Instalações prediais de águas pluviais. Rio de Janeiro, 1989.

$13 \mathrm{p}$.

NBR 10897: Sistemas de proteção contra incêndio por chuveiro automático - Requisito. Rio de Janeiro, 2007. 108 p.

. NBR 12721: Avaliação de custos unitários e preparo de orçamento de construção para incorporação de edifícios em condomínio - Procedimento. Rio de Janeiro, 1999. 63 p.

NBR 13531: Elaboração de projetos de edificações - Atividades técnicas. Rio de Janeiro, 1995. 10 p. 
NBR 14039: Instalações elétricas de média tensão de 1,0kV a 36,2kV. Rio de Janeiro, 2005. $87 \mathrm{p}$.

. NBR 15526: Redes de distribuição interna para gases combustíveis em instalações residenciais e comerciais - Projeto e execução. Rio de Janeiro, 2009. $44 \mathrm{p}$.

NBR 15575-1: Edifícios habitacionais de até cinco pavimentos Desempenho. Parte 1: Requisitos gerais. Rio de Janeiro, 2008. 52 p.

NBR 15575-4: Edifícios habitacionais de até cinco pavimentos Desempenho. Parte 4: Sistemas de vedações verticais externas e internas. Rio de Janeiro, 2008. $51 \mathrm{p}$.

NBR 16401-1: Instalações de ar condicionado - Sistemas centrais e unitários. Parte 1: Projetos das instalações. Rio de Janeiro, 2008. 60 p.

NBR 16401-2: Instalações de ar condicionado - Sistemas centrais e unitários. Parte 2: Parâmetros de conforto térmico. Rio de Janeiro, 2008. 7 p.

NBR 16401-3: Instalações de ar condicionado - Sistemas centrais e unitários. Parte 3: Qualidade do ar interior. Rio de Janeiro, 2008. 24 p.

NBR NM 195: Projeto, fabricação e instalação de escadas rolantes e esteiras rolantes - Procedimento. Rio de Janeiro, 1999. 79 p.

. NBR NM 207: Elevadores de passageiros - Requisitos de segurança para construção e instalação. Rio de Janeiro, 1999. 140 p.

NBR NM 313: Elevadores de passageiros - Requisitos de segurança para construção e instalação - Requisitos particulares para a acessibilidade das pessoas, incluindo pessoas com deficiência. Rio de Janeiro, 2007. 32 p.

AFLALO, M.; VIANNA, G. Croce, Aflalo e Gasperini Arquitetos. São Paulo: Univers, 1999. 79 p.

ATKIN, B.; BROOKS, A. Total facilities management. $3^{\text {rd }}$ edition. Oxford: Wiley Blackwell, 2009. 328 p. 
AUSTIN, S. et al. Analytical design planning technique: a model of the detailed building design process. Design Studies, Oxford, v. 20, n. 3, p. 279-296, 1999.

BECKER, F.; STEELE, F. Workplace by design: Mapping the high-performance workscape. San Francisco: Jossey-Bass, 1995. 228 p.

BENEVOLO, L. História da Arquitetura Moderna. São Paulo: Perspectiva, 1976. $813 \mathrm{p}$.

BOTTI, A.; RUBBIN, M. Apresenta dados sobre projetos e obras realizadas. Disponível em: < http://www.bottirubin.com.br/2009/pt.html>. Acesso em 13 out. 2009.

Botti Rubin Arquitetos: Selected and current works. Australia: Images Publishing, 2002.

Botti Rubin Arquitetos. São Paulo: J.J. Carol, 2009. 104 p.

BRASIL. Ministério da Aeronáutica. Comando Geral de Apoio. Diretoria Eletrônica e Proteção ao Vôo. Portaria 018/GM5 de 14 de fevereiro de 1974: Instruções para operação de helicópteros e para construção e utilização de helipontos ou heliportos. Disponível em: <http:// www.anac.gov.br/biblioteca/aeroportosInfraestrutura.asp>. Acesso em 05 fev. 2009.

BRATKE, C.; MAIA, E.; WISSENBACH, V. Carlos Bratke, arquiteto. São Paulo: ProEditores, 1995. $171 \mathrm{p}$.

BRATKE, C. Apresenta histórico da carreira, projetos e obras realizadas. Disponível em: < http://www.carlosbratke.com.br/>. Acesso em 13 out. 2009.

BROWN, P. D. H.; HAYWARD, M.;BROWN, P. Occupier issues. In: BATTLE, T. (editor). The commercial offices handbook. London: RIBA Enterprises, 2003. p.429-445.

CABRAL, Marcelo. A onda verde chegou aos escritórios. Revista Exame, São Paulo, edição de 02 Dez 2007. Disponível em:

<http://www.cte.com.br/noticias.asp?id=523>. Acesso em: 01 Jul 2008 
CASTRO NETO, J. S. Edifícios de elevada tecnologia. 1991. Tese (doutorado). Escola Tecnica Superior de Arquitectura, Universidad de Madrid. Madri, 1991.

CEOTTO, L. H. A sustentabilidade como valor estratégico para a Tishman Speyer. Trabalho apresentado ao Encontro Internacional de Sustentabilidade na Construção, São Paulo, 19 de jun 2008. Não publicado.

CHVATAL, K. M. S.; LABAKI, L.; KOWALTOWSKY, D. C. C. K. A prática do projeto arquitetônico em Campinas, SP, e diretrizes para o projeto de edificações adequadas ao clima. In: NUTAU'1998: Arquitetura e urbanismo: tecnologias para o séc. XXI. Anais...São Paulo, 1998.

COWAN, H. J. Architectural Structures - An Introduction to Structural Mechanics. New York: Elsevier, 1976.

CRANE, R.; DIXON, M. Architect's data sheets: Office spaces. London: Architecture Design and Technology Press, 1991. 94 p.

CRESPO, C. C.; RUSCHEL, R. C. Ferramentas BIM: um desafio para melhoria no ciclo de vida do projeto. In: III Encontro de tecnologia de informação e comunicação na construção civil. Anais... Porto Alegre, 2007.

DAL MONTE, P. J. Elevadores e escadas rolantes. Rio de Janeiro: SCP, 2000.

DE MARTINI, J. L. Infra-estrutura para edifícios e centros comerciais. Revista Lumiére, Jul. 2008. Disponível em:

<http://www.revistalumiere.com.br/ver artigo.php?id=106>. Acesso em 27 nov. 2008.

DIAS, L. A. M. Aço e Arquitetura: estudo de edificações no Brasil. São Paulo: Zigurate, 2001. $171 \mathrm{p}$.

DUARTE, $P$. Tecnologia de fachadas para arquitetos. Palestra proferida na Faculdade de Arquitetura e Urbanismo da Universidade de São Paulo, São Paulo, 13 out. 2009. Não publicado.

DUFFY, F.; CAVE, C.; WORTHINGTON, J. Oficinas - Manuales AJ. Trad: Rafael Fontes. Madrid: H. Blume Ediciones, 1980. 248 p.

DUFFY, F. The new Office. London: Conran Octopus Limited, 1999. 256 p. 
EGAN, M. David. Architectural acoustics. EUA: McGraw-Hill, 1988. 411 p.

ELEVADORES ATLAS SCHINDLER S.A. Departamento Técnico. Manual de transporte vertical em edifícios. Ed. 18. São Paulo: Pini, 2001. 40 p.

ELEVADORES OTIS LTDA. Manual do projetista. Ed. 7. São Paulo, 1996. 47 p. (BRA-062).

ELEY, J.; MARMOT, A. Understanding offices - What every manager needs to know about office buildings. London: Penguin Books, 1995. 199 p.

EUBANK, H. O movimento mundial da construção sustentável. Trabalho apresentado ao Encontro Internacional de Sustentabilidade na Construção, São Paulo, 19 de jun 2008. Não publicado.

FABRICIO, M. M. Projeto simultâneo na construção de edifícios. 2002. 329 p. Tese (Doutorado). Escola Politécnica, Universidade de São Paulo. São Paulo: 2002.

FARIA, R. Subida rápida. Revista Téchne. Edição 139, outubro 2008. Disponível em: < www.revistatechne.com.br/engenharia-civil/subida-rapida-105403-1.asp > . Acesso em: 10 Nov 2008.

FARINA, H. Formulação de diretrizes para modelos de gestão da produção de projetos de sistemas prediais. 2002. 130 p. Dissertação (Mestrado). Escola Politécnica, Universidade de São Paulo, São Paulo: 2002.

FERNANDES, A.; SALVADOR, F. Compras públicas passarão a seguir critérios ambientais. Jornal O Estado de São Paulo, São Paulo, edição de 16 Jul 2008.

FERREIRA, J. J. A. O modelo francês de certificação HQEI AQUA e sua aplicação no Brasil. Trabalho apresentado ao Encontro Internacional de Sustentabilidade na Construção, São Paulo, 19 de jun 2008. Não publicado.

FERREIRA, A. B. H. O novo dicionário Aurélio da Língua Portuguesa. Edição eletrônica, Positivo Informática, 2009. Disponível em:

<www.educacional.com.br/dicionarioaurelio/home.asp>. Acesso em: 17 Fev. 2010. 
FIALHO, R. N. Edifícios de escritórios na cidade de São Paulo. 2007. 385 p. Tese (Doutorado). Faculdade de Arquitetura e Urbanismo, Universidade de São Paulo, São Paulo: 2007.

FLORIO, W. Contribuições do Building Information Modeling no processo de projeto em arquitetura. In: III Encontro de tecnologia de informação e comunicação na construção civil. Anais... Porto Alegre, 2007.

FRANÇA \& ASSOCIADOS ENGENHARIA. Projeto de estruturas de edifícios altos. Trabalho apresentado na Faculdade de Engenharia do Instituto Mackenzie, 2007. Não Publicado.

FREJ, A. et al. Green Office Buildings: A Practical Guide to Development. Washington DC: ULI - Urban Land Institute, 2005. 366 p.

FROTA, A. B.; SCHIFFER, S. R. Manual do conforto térmico. São Paulo: Studio Nobel, 1999. 244 p.

FUNDAÇÃO VANZOLINI. Apresenta recursos e atividades desenvolvidas.

Disponível em: <www.vanzolini.org.br>. Acesso em: 09 Fev. 2010.

GIDO, J.; CLEMENTS, J. P. Gestão de projetos. Tradução da $3^{a}$ edição norteamericana: Vertice Translate; revisão técnica: Melhado, S. B. São Paulo: Thomson Learning, 2007. $451 \mathrm{p}$.

GOMES, V. Arquitetura e sustentabilidade. Trabalho apresentado à Orbi, São Paulo, 02 Mar 2007. Não publicado.

GONÇALVES, I; WHITAKER, T. CIB - Agenda 21 para a construção sustentável. Tradução do relatório CIB publicação 237. São Paulo: edição de Weinstock \& Weinstock, 2000.

GRAÇA, M. E. A. Formulação de modelos para avaliação das condições determinantes da necessidade de ventilação secundária em sistemas prediais de coleta de esgotos sanitários. 1985. 357 p. Tese (Doutorado). Escola Politécnica, Universidade de São Paulo. São Paulo, 1985.

GREEN BUILDING COUNCIL BRASIL. Apresenta recursos e atividades desenvolvidas. Disponível em: <www.gbcbrasil.org.br>. Acesso em: 09 Fev. 2010. 
GRILO, L.M. Gestão do processo de projeto no segmento de edifícios por encomenda. 2002. 370 p. Dissertação (Mestrado). Escola Politécnica, Universidade de São Paulo. São Paulo: 2002.

HAEBER, J. Frank Lloyd Wright and his forgotten Larkin Building. Disponível em: <http://www.terrastories.com/bearings/frank-lloyd-wright-and-his-forgotten-larkinbuilding >. Acesso em: 04 Dez 2009.

HARTKOPF, V. et al. Designing the office of the future - The japanese approach to tomorrow's workplace. New York: John Wiley\& Sons, 1993. 264 p.

HALL, A.; SHUTTLEWORTH, K.; HYAMS, R. Facades. In: BATTLE, T. (editor). The commercial offices handbook. London: RIBA Enterprises, 2003.

HEINLE, E.; LEONHARDT, F. Towers - A historical survey. New York: Rizzoli International Publications, 1989. 343 p.

HERNANDEZ NETO, A.; VITTORINO, F. Sistema de ar condicionado em edifícios: inovações, tendências e conservação de energia. São Paulo, Centro RPA de Atualização Profissional e Educação Continuada. Documento disponibilizado no curso de Sistemas de Ar Condicionado (AC05), RPA Editorial, 2003.

HERZOG, T; KRIPPNER, R; LANG, W. Facade construction manual. Basel: Birkhäuser Verlag, 2008. 320 p.

JONES LANG LASALLE. The investment case for Brazil. Relatório, 2009. 24 p. Disponível em:

$<$ www.joneslanglasalle.com.br/ResearchLevel1/Investment_Case_for_Brazil_2009.p df>. Acesso em: 15 Jul 2009.

KAYA, S. Relating building attributes to end user's needs: "the owners - designers end users" equation. Facilities, vol. 22, number 9/10, 2004. p. 247-252.

KHOURY, J. Curtain Walls. In: KOHN, A. E.; KATZ, P. Building type basics for office buildings. New York: John Wiley \& Sons, 2002. p. 139-158.

KOHN, A. E.; KATZ, P. Building type basics for office buildings. New York: John Wiley \& Sons, 2002. 294 p. 
KURTZ, N. D. Mechanical/ Electrical/ Plumbing systems. In: KOHN, E.; KATZ, P. Building type basics for Office buildings. New York: John Wiley \& Sons, 2002. p. 103-120.

LEITE, B. C. C. Análise do desempenho de edifícios de escritórios automatizados através da avaliação pós-ocupação. Dissertação (Mestrado). 1997. Faculdade de Arquitetura e Urbanismo, Univesidade de São Paulo. 385 p.

Sistema de ar condicionado com insuflamento pelo piso em ambientes de escritório: Avaliação do conforto térmico e condições de operação. 2003. 162 p. Tese (Doutorado). Escola Politécnica, Universidade de São Paulo. São Paulo: 2003.

Res: Tese de mestrado - orientanda do prof. Silvio Melhado.

[mensagem pessoal]. Mensagem recebida por: <anawansul@gmail.com> em: 27 mar. 2009.

LORDSLEEM JR, A.C. O processo de produção das paredes maciças. In: Tecnologia e gestão na produção de edifícios - Seminário: Vedações verticais. Anais. São Paulo: Escola Politécnica da Universidade de São Paulo, 1998.

LOTURCO, Bruno. Choque de economia. Revista Téchne, ed. 138, Set. 2008. Disponível em: <http://www.revistatechne.com.br/engenharia-civil/138/artigo1024011.asp>. Acesso em 19 nov. 2008.

MACGREGOR, J. G. Reinforced concrete: mechanics and design. $3^{\text {rd }}$ ed. New Jersey: Prentice-Hall, 1988. 939 p.

MAHFUZ, E. Edson Mahfuz fala sobre as fachadas contemporâneas. Revista AU Arquitetura \& Urbanismo. São Paulo, edição de julho, $n^{\circ} 184,2009$. Disponível em: $<$ http://www.revistaau.com.br/arquitetura-urbanismo/184/edson-mahfuz-fala-sobreas-fachadas-contemporaneas-142816-1.asp>. Acesso em 13 out. 2009.

MANNING, P. Office design. Liverpool: University of Liverpool, 1965.

Manuais de escopo de projetos e serviços. Disponíveis em: <www.manuaisdeescopo.com.br>. Acesso em 13 mar. 2009.

MARTE, C. L. Automação - A inteligência distribuída nas edificações. São Paulo: Carthago \& Forte, 1995. 120 p. 
MANZIONE, L. Estudo de métodos de planejamento do processo de projeto de edifícios. 2006. 250 p. Dissertação (Mestrado). Escola Politécnica, Universidade de São Paulo, São Paulo: 2006.

MARGARIDO, A. F. Fundamentos de Estruturas. São Paulo: Zigurate, 2001. 336p.

MELHADO, S. B. et al. Coordenação de projetos de edificações. São Paulo: O Nome da Rosa, 2005. 115p.

MELHADO, S. B.; AGOPYAN, V. O conceito de projeto na construção de edifícios: diretrizes para sua elaboração e controle. Boletim Técnico. EPUSP. Departamento de Engenharia de Construção Civil, BT/PCC/139. São Paulo: 1995.

MENDLER, S.; ODELL, W.; LAZARUS, M. A. The HOK Guidebook to Sustainable Design. New York: Willey, 2006. 480 p.

MORREL, P. The cost management process - designing and procuring for value. In: BATTLE, T. (editor). The commercial offices handbook. London: RIBA Enterprises, 2003. p. 43-81.

NASCIMENTO, L. A. Proposta de um sistema de recuperação de informação para extranet de projeto. 2004. 123 p. Dissertação (Mestrado). Escola Politécnica, Universidade de São Paulo, São Paulo: 2004.

NATIONAL FIRE PROTECTION ASSOCIATION. NFPA 550 - Guide to fire safety concepts tree. Quincy, MA, 2002.

OESTERLE, E. et. al. Double-skin facades. Munich : Prestel Verlag, 2001. 207 p.

OLIVATO, P. Aflalo e Gasperini: Edifícios Corporativos: Família Atrium. São Paulo: Ateliê Editoral, 2004. 57 p.

OLIVEIRA, L. Metodologia para desenvolvimento de projeto de fachadas leves. 2009. Tese (Doutorado). Escola Politécnica, Universidade de São Paulo. São Paulo: 2009.

OLIVEIRA, L. H. Metodologia para a implantação de programa de uso racional de água em edifícios. 1999. 344 p. Tese (Doutorado). Escola Politécnica, Universidade de São Paulo, São Paulo: 1999. 
OLIVEIRA, L. H. Sistemas prediais hidráulicos em edifícios altos. Revista Hydro, São Paulo, edição de março, p. 56-59, 2008.

ONO, R. Parâmetros para garantia da segurança da qualidade do projeto de segurança contra incêndios em edifícios altos. Revista Ambiente Construído, São Paulo, v.7, edição de janeiro/ março, 2007.

ORBI. Projeto $\mathbf{n}^{\circ}$ 217: planta tipo. 07 nov. 2007. Projeto executivo. Desenhista: Mirella. Folha 132.

ORBI. Projeto TSP: corte típico. 30 jun. 2008. Estudo preliminar. Desenhista: Edison. Folha ARQ-2100.

ORNSTEIN, S. W.; ROMÉRO, M. Avaliação pós-ocupação (APO) do ambiente construído. São Paulo: EDUSP, 1992. 223 p.

PACIFIC INSTITUTE. Califórnia (EUA). Modelos para comparação de cenários no equacionamento de energia e uso da água. Disponível em:

$<$ http://www.pacinst.org/resources/water to air modes/index.htm>. Acesso em 11 fev. 2009.

PIRRÓ, L. O impacto das envolventes verticais no desempenho energético de edifícios de escritório. 2005. Tese (Doutorado). Faculdade de Arquitetura e Urbanismo, Universidade de São Paulo. São Paulo: 2005.

PROJECT MANAGEMENT INSTITUTE. Project management book of knowledge (PMBoK 2000). Disponível em: <www.pmi mg.com.br> . Acesso em 25 Out. 2006.

PUGLIESE, M. H. Carlos Bratke: Arquitetura. São Paulo: Companhia Editora Nacional, 2005. 141 p.

REBELLO, Y.C.P. A concepção estrutural e a arquitetura. São Paulo: Zigurate, 2000. 272 p.

ROBERTSON, L. E.; SEE, S. Structural systems. In: KOHN, E,; KATZ, P. Building type basics for office buildings. New York: John Wiley \& Sons, 2002. p. 83-101. 
ROMANO, F. V. Modelo de referência para o gerenciamento do processo de projeto integrado de edificações. Tese (Doutorado). 2003. Universidade Federal de Santa Catarina. Florianópolis, 2003. 326 p.

RONDEAU, E. P.; BROWN, R. K. ; LAPIDES, P. D. Facility Management. New York: John Willey \& Sons, 1995. p. 3-4.

ROSENAUER, M. Modern office buildings. London: B. T. Batsford, 1955.

SABBATTINI, F. H. et. al. Notas de aula da disciplina de Tecnologia da Construção Civil I - PCC 2435. São Paulo: Epusp, 2007. Disponível em <http://pcc2435.pcc.usp.br/Aulas\%20em\%20pdf-2006-2007/4-\%20Vedações\%20 Verticais/aula\%2018\%20vedações-v1.pdf>. Acesso em 14 out. 2009.

SANTOS, A. B. A interface do elevador na arquitetura, aspectos projetuais, éticos e sociais. 2007. 111 p. Dissertação (Mestrado) - Faculdade de Arquitetura e Urbanismo da Universidade de São Paulo. São Paulo, 2007.

SANTOS, L. S. Proposta de ferramenta para verificação da manutenibilidade de edifícios comerciais. 2007. 98 p.Monografia (MBA) - Escola Politécnica da Universidade de São Paulo. São Paulo, 2007.

SÃO PAULO (Estado). Polícia Militar do Estado de São Paulo. Corpo de Bombeiros. Regulamento de segurança contra incêndio das edificações e áreas de risco do Estado de São Paulo: Decreto Estadual no 46.076/01. São Paulo: Corpo de Bombeiros, 2005. 1 CD-ROM.

SÃO PAULO (MUNICÍPIO). Lei 11.228 de 25 de junho de 1992. Código de obras e edificações do município de São Paulo. Disponível em:

$<$ http://plantasonline.prefeitura.sp.gov.br/legislacao/legislacao.php>. Acesso em 24 jul. 2008.

. Lei 13.276 de 04 de janeiro de 2002. Torna obrigatória a execução de reservatório para as águas coletadas por coberturas e pavimentos nos lotes, edificados ou não, que tenham área impermeabilizada superior a 500m². Disponível em:

$<$ http://www3.prefeitura.sp.gov.br/cadlem/secretarias/negocios juridicos/cadlem/pes qnumero.asp?t=L\&n=13276\&a=\&s=\&var=0>. Acesso em 11 fev. 2009. 
. Lei 13.885 de 25 de agosto de 2004. Zoneamento da cidade de São Paulo. Disponível em: <http://sempla.prefeitura.sp.gov.br/urb_zon.php>. Acesso em 03 fev. 2009.

SCHMIDT, W. Caracterização e formulação de parâmetros para avaliação de mictórios - O caso do mictório sem água. 2003. 247 p. Dissertação (Mestrado). Escola Politécnica, Universidade de São Paulo, São Paulo: 2003.

SCHMERTZ, M. F. Office building design. New York: Mc-Graw-Hill, 1975.

SKIDMORE, OWINGS \& MERRILL. Apresenta projetos e atividades desenvolvidas. Disponível em: <www. som.com >. Acesso em: 07 Jul 2008.

SOUTO, A. K.; SILVA, D. M. Estruturas - Uma Abordagem Arquitetônica. Porto Alegre: Ed. Sagra Luzzatto, 2000.

STOECKER, W. F.; JONES, J. W. Refrigeração e ar condicionado. Tradução José M. Saiz Jabardo et al. São Paulo: McGraw-Hill do Brasil, 1985. 481 p.

SWAFFIELD, John. Traps in the system. World Plumbing Review, Australia, v.1, p. 82-86, 2006.

TISHMAN SPEYER. Apresenta empreendimentos e atividades desenvolvidas. Disponível em: <www.tishmanspeyer.com.br>. Acesso em: 03 Nov. 2009.

TORROJA, E. Razón y ser de los tipos estrutucturales. $3^{\text {a }}$ ed. Madrid: Instituto Eduardo Torroja de la construcción y del cemento, 1960. 403 p.

US GREEN BUILDING COUNCIL. LEED Green building rating system for core \& shell development. Version 2, Jul 2006. Disponível em: <www.usgbc.org>. Acesso em: 04 Jul 2008.

VAN DEUSEN, John. Vertical Transportation. In: KOHN, A. E.; KATZ, P. Building type basics for Office buildings. New York: John Wiley \& Sons, 2002. p. 121-137.

VASCONCELOS, R. L. Edifícios de escritórios: arquitetura, energia e automação. Dissertação (Mestrado). 2005. Faculdade de Arquitetura e Urbanismo, Universidade de São Paulo. São Paulo, 2005. 
VERONEZI, A. B. Sistema de certificação da qualidade de edifícios de escritório no Brasil. 2004. 146 p. Dissertação (Mestrado). Escola Politécnica, Universidade de São Paulo, São Paulo, 2004.

WIKIMEDIA FOUNDATION . Wikipédia. Apresenta conteúdo enciclopédico. Definição para desenvolvimento sustentável. Disponível em:

<http://pt.wikipedia.org/w/index.php?title=Desenvolvimento_sustent\%C3\%A1vel\&oldi $\mathrm{d}=11209620>$. Acesso em: 30 Jun 2008.

Wikipédia. Apresenta conteúdo enciclopédico. Definição para green building. Disponível em:

<http://en.wikipedia.org/w/index.php?title=Green_building\&oldid=223353912>. Acesso em: 03 Jul 2008

. Wikipédia. Apresenta conteúdo enciclopédico. Definição para sustentabilidade. Disponível em:

<http://pt. wikipedia.org/w/index.php?title=Sustentabilidade\&oldid=11219017>. Acesso em: 26 Jun 2008.

WORLD GREEN BUILDING COUNCIL. Apresenta recursos e atividades desenvolvidas. Disponível em: <www.worldgbc.org>. Acesso em: 09 Fev 2010.

YEANG, K. Ecodesign - A Manual for Ecological Design. Great Britain: WileyAcademy, 2006. 499 p.

YIN, R. K. Estudo de caso: planejamento e métodos. Trad. Daniel Grassi. $3^{a}$ edição. Porto Alegre: Bookman, 2005. 212 p. 